\section{POLIIKK HUKUM LIDONESIA}

TEORI DAN PRAKTIK

Kumpulan tulisan ini berawal dari kegelisahan para penulis sebagai alumni Magister IImu Hukum Universitas Islam Indonesia Yogyakarta yang melihat tradisi menulis tentang materi hukum di negeri ini masih didominasi oleh metode normatif - deduktif. Metode ini tidak memperkaya pemahaman kita mengenai hukum yang sesungguhnya, yang jauh lebih kompleks daripada bentuk penampilannya yang hanya yuridis-normatif. Di sisi lain disadari atau tidak disadari, metode interdispliner, transdispliner, sangat diperlukan dalam memahami dan menjawab tantangan perkembangan hukum ke depan.

Usaha untuk mencari kebenaran dan kenyataan di dalam hukum, para Penulis yang berasal dari berbagai cabang bidang studi hukum yaitu Hukum Tata Negara, Hukum Administrasi Negara, Hukum Agraria dan Hukum Ekonomi melakukan kajian dengan memaparkan hubungan kuasa antara konfigurasi politik dan produk hukum dalam kajian berbagai cabang ilmu hukum yang diulas secara kritis. Oleh karena itu, substansi buku ini jelas berbeda dengan tulisan-tulisan yang menggunakan pendekatan normatif semata.

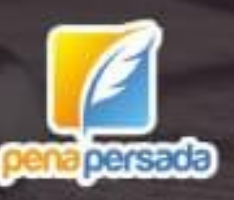

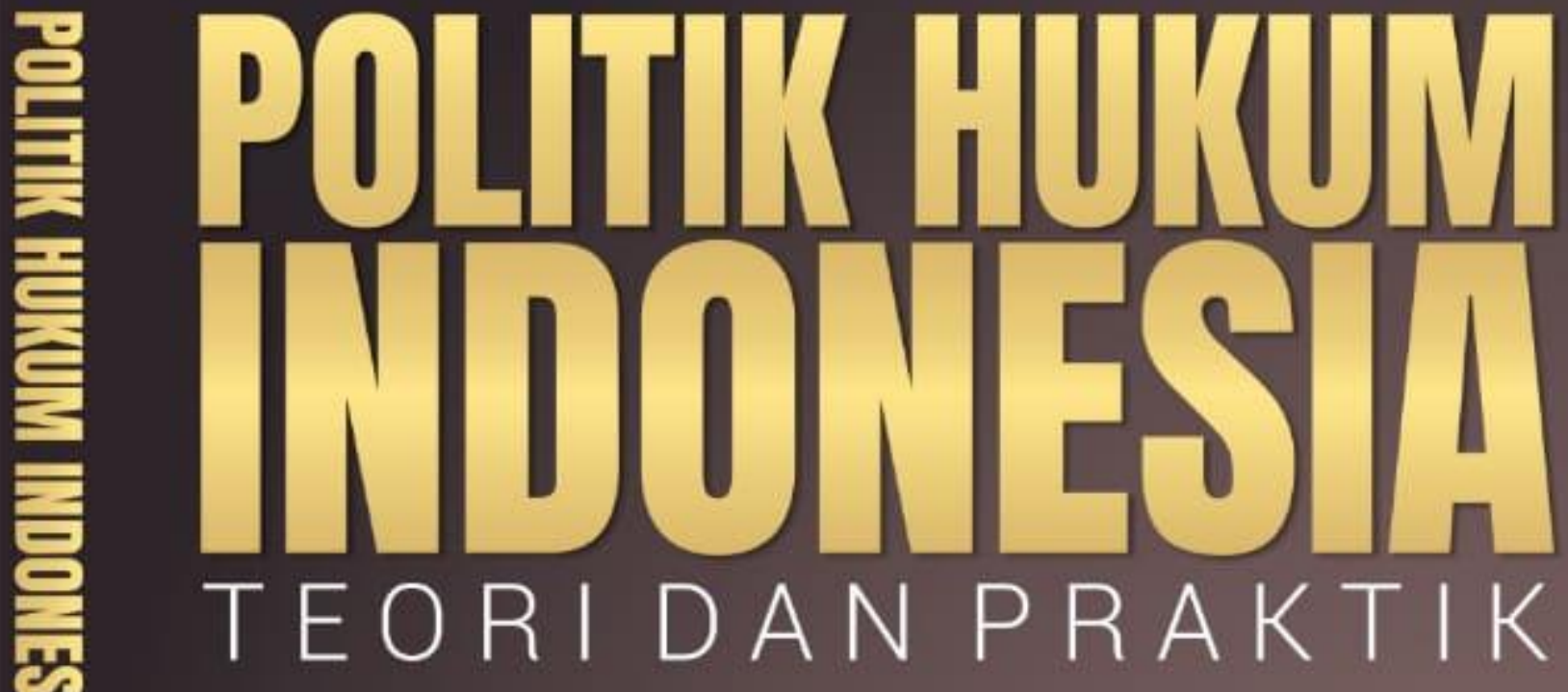

Adam Setiawan | Nehru Asyikin | Rheza Firmansyah

Satria Sukananda | Fatma Hidayati | Reni Ratna Anggreini Rivaldhy Harmi | Ade Riyanda Prasetia Putra

Kata Pengantar

Prof. Dr. Ni'matul Huda, S.H., M. Hum

(Guru Besar Hukum Tata Negara Universitas Islam Indonesia)

긏

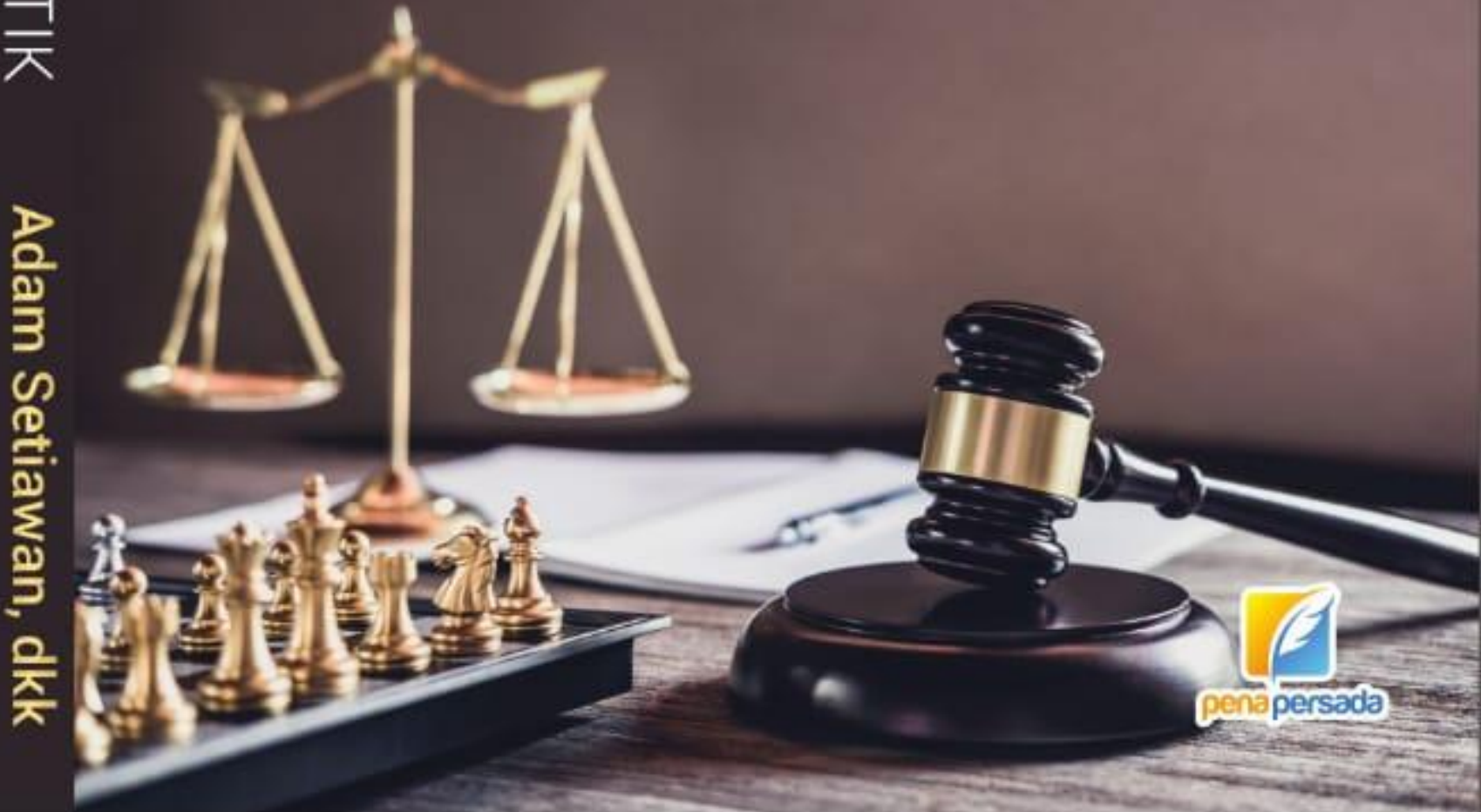




\title{
POLITIK HUKUM INDONESIA \\ Teori dan Praktik
}

\author{
Adam Setiawan \\ Nehru Asyikin \\ Rheza Firmansyah \\ Satria Sukananda \\ Fatma Hidayati \\ Reni Ratna Anggreini \\ Rivaldhy Harmi \\ Ade Riyanda Prasetia Putra
}

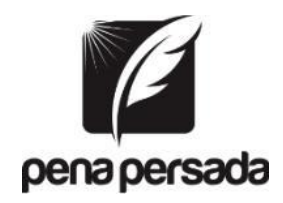

PENERBIT CV. PENA PERSADA 


\title{
POLITIK HUKUM INDONESIA \\ Teori dan Praktik
}

\author{
Penulis : \\ Adam Setiawan \\ Nehru Asyikin \\ Rheza Firmansyah \\ Satria Sukananda \\ Fatma Hidayati \\ Reni Ratna Anggreini \\ Rivaldhy Harmi \\ Ade Riyanda Prasetia Putra \\ ISBN : 978-623-6504-92-5 \\ Design Cover : \\ Retnani Nur Briliant \\ Layout: \\ Fajar T. Septiono

\section{Penerbit CV. Pena Persada} \\ Redaksi : \\ Jawa Tengah \\ Email : penerbit.penapersada@gmail.com \\ Website : penapersada.com \\ Phone : (0281) 7771388
}

Jl. Gerilya No. 292 Purwokerto Selatan, Kab. Banyumas

\section{Anggota IKAPI}

All right reserved

Cetakan Pertama: 2020

Hak Cipta dilindungi oleh Undang Undang. Dilarang memperbanyak karya tulis ini dalam bentuk apapun tanpa seizin penerbit 


\section{KATA PENGANTAR}

\section{Politik Hukum Ketatanegaraan Indonesia}

Oleh:

Prof. Dr. Ni'matul Huda, S.H., M.Hum

Guru Besar Hukum Tata Negara Universitas Islam Indonesia

Buku yang hadir di hadapan pembaca dengan judul "Politik Hukum Teori dan Praktik" adalah karya intelektual muda yang sangat concern dengan perkembangan hukum di Indonesia, dalam kajian berbagai cabang ilmu hukum yang diulas secara kritis. Pilihan fokus kajian dan analisis terhadap problematika hukum di Indonesia dalam perspektif politik hukum setidaknya menyiratkan penilaian terhadap hukum yang sekarang berlaku dan tawaran solusi ke depan terhadap problematika yang dikaji. Buku ini menarik karena beragam kajian cabang ilmu hukum dibedah dalam perspektif politik hukum.

Kajian politik hukum menjadi menarik karena lingkup bahasannya tidak hanya dapat dilihat dalam konteks bagaimana hukum di desain, tetapi juga harus dilihat darimana sumber hukum diperoleh, bagaimana kompromi-kompromi politik dicapai, bagaimana konfigurasi politiknya, apakah hukum yang dibentuk sudah mencerminkan rasa keadilan, kepastian dan kemanfaatannya bagi masyarakat luas atau justru sebaliknya, hukum yang dibentuk itu hanya menguntungkan individu, kelompok, atau partai politik tertentu saja dan jauh dari cita-cita hukum yang akan memberikan keadilan dan kesejahteraan bagi masyarakat. Dengan demikian, kajian politik hukum membutuhkan kecermatan, kedalaman, dan kehati-hatian dalam mengkajinya. Opini publik seringkali menyesatkan bacaan publik karena hanya memotret persoalan dari permukaan saja, tetapi politik hukum harus menyelaminya lebih dalam pesan-pesan yang tersembunyi dari rangkaian kata-kata indah dalam sebuah norma perundang-undangan. Seperti yang belakangan ini disorot dan ditolak oleh publik khususnya umat Islam terkait Rancangan Undang-undang Haluan Ideologi Pancasila (RUU HIP). Umat Islam sangat terusik dengan muatan materi yang menempatkan 
Pancasila sebagai norma dan mereduksi Pancasila menjadi Trisila atau bahkan Ekasila. Padahal Pancasila itu merupakan dasar filosofi negara yang menjadi sumber dari segala sumber hukum di Indonesia. Penolakan yang begitu kuat dari umat Islam terhadap RUU HIP tersebut menyiratkan bahwa ada agenda setting dari pembentuk undang-undang yang dimasukkan ke dalam norma-norma sebuah RUU baik yang tersembunyi maupun yang terang benderang bisa diketahui muatan politik tersembunyi dari desainernya.

Saya menyambut baik hadirnya buku ini, agar dapat ikut meramaikan kajian-kajian keilmuan bidang hukum, sehingga dapat berkontribusi membangun dan mengembangkan atmosfir akademik serta budaya akademik untuk terus menulis, menuangkan ide dan gagasan kritis dan konstruktifnya.

Saya mengenal penulis buku ini adalah alumni-alumni Magister Hukum Fakultas Hukum Universitas Islam Indonesia yang kreatif dan potensial. Semoga buku ini bukan menjadi catatan akhir mereka dalam karirnya, tetapi menjadi awal untuk membuka pintu hidayah keilmuannya sehingga akan memberi berkah bagi penulis maupun dunia akademik Indonesia di masa yang akan datang. Semoga segera disusul dengan karya2nya yang lain. Aamiin. Ya Mujibassailin.

Yogyakarta, 14 Juli 2020 


\section{KATA PENGANTAR PENULIS}

Politik hukum merupakan ilmu yang telah memberikan pemahaman, bahwa hukum tidak hanya pada wilayah penerapan hukum semata, tetapi kajiannya mencakup proses pembentukan, arah kebijakan dan tujuan kebijakan hukum itu dibentuk, yang pada akhirnya terdampak oleh kebijakan tersebut adalah kelompok masyarakat atau dirasakan oleh individu itu sendiri.

Buku yang saat ini di baca para akademisi, masyarakat dan mahasiswa merupakan kumpulan dari tulisan-tulisan Alumnus Program Magister Ilmu Hukum Universitas Islam Indonesia Yogyakarta dan Mahasiswa Program Magister Ilmu Hukum Universitas Islam Indonesia Yogyakarta. Dalam pandangan para penulis, Politik Hukum menjadi Ilmu Hukum agar tetap kritis dan memahami perkembangan kebijakan hukum dalam bernegara, sehingga dalam menentukan arah pembangunan hukum, Politik Hukum menjadi domain penting sebagai titik penentu dalam mencapai tujuan bernegara itu sendiri. Meskipun kumpulan tulisan ini tidak seluruhnya menjawab problematika hukum Indonesia dalam menentukan arah kebijakan penguasa, namun tulisan ini paling tidak sudah menghadirkan permasalahan-permasalahan yang saat ini terasa dalam kehidupan bernegara.

Pada titik ini, permasalahan dalam penentuan arah kebijakan (policy) tersebut selalu menimbulkan polemik, karena dalam pengambilan keputusan oleh penguasa tidak menutup kemungkinan permasalahan baru akan muncul, atau paling tidak tidak tepat sasaran yang pada akhirnya masyarakat yang dirugikan. Di sinilah, para pembaca akan di bawa pada pandangan Politik Hukum atas arah-arah kebijakan yang di ajukan oleh penguasa baik di parlemen maupun eksekutif.

Meskipun dalam konteks Politik Hukum yang lebih luas, kumpulan tulisan ini tidak secara kompleks dan mengkaji secara detail isu-isu hukum yang berkaitan Politik Hukum, namun para penulis percaya jika Buku ini cukup untuk memberikan wawasan para pembaca dalam melihat realitas Pemberantasan Korupsi oleh 
Pemerintah, Hak Asasi dalam Administrasi, Permasalahan Dana Desa, Perkembangan Zakat, Wakaf dan Ekonomi Syariah, Permasalahan Pertanahan dalam Penanaman Modal dan Investasi di Indonesia, Penanggulangan Tindak Pidana Terorisme.

Para penulis harapkan, buku ini akan menjadi sumbangan pemikiran kepada bangsa dan negara atas keilmuan yang tidak seberapa ini dari para penulis. Namun para penulis percaya jika kritik atas Politik Hukum di Indonesia semata-mata karena kepedulian sebagai anak bangsa atas arah kebijakan hukum yang merugikan masyarakat dan terlebih menjadi kerugian besar bagi bangsa ini.

Sehingga atas persembahan buku ini, kami haturkan dari lubuk hati yang terdalam, ucapan terima kasih kepada para Dosen Program Magister Ilmu Hukum khususnya Prof. Dr. Ni'matul Huda, S.H., M.Hum yang telah bersedia memberikan kata pengantar pada tulisan ini. Tanpa beliau-beliau, Ilmu Hukum yang sudah di dapat di Starata 1 (satu) kurang lengkap apabila tanpa pemahaman atas Politik Hukum tersebut, karena demikian, realitas arah kebijakan Indonesia menjadi tabu dan sulit di fahami. Kepada mereka, Kami Ucapkan Terima Kasih...

Yogyakarta, 14 Juli 2020 Penulis 


\section{DAFTAR ISI}

KATA PENGANTAR Prof. Ni'matul Huda .................................. iii

KATA PENGANTAR PENULIS............................................... $\mathrm{v}$

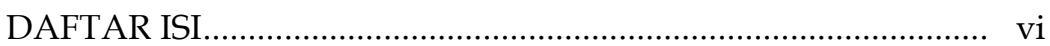

Politik Hukum Pemerintah Dalam Pemberantasan Korupsi di Era Reformasi

A. Pendahuluan...................................................................... 1

B. Relasi Hukum dan Politik ...................................................... 9

C. Definisi Politik Hukum ....................................................... 11

D. Politik Hukum Pemberantasan Korupsi ............................. 14

E. Karakter Produk Hukum Pemberantasan Korupsi............. 32

F. Penutup ....................................................................... 39

Politik Hukum Terhadap Pengakuan Hak Asasi Warga Negara Indonesia di dalam Hukum Administrasi Negara

A. Pendahuluan .................................................................... 46

B. Politik Hukum Hak Asasi Warga Negara Indonesia dalam Hukum Administrasi Negara................................... 49

C. Hukum Administrasi Negara Melindungi Hak Asasi

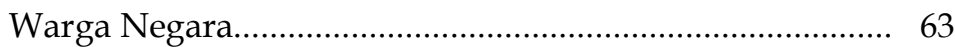

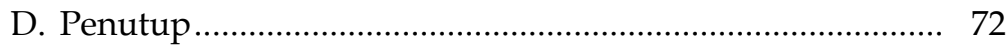

Politik Hukum Pengelolaan, Pertanggungjawaban, dan Pengawasan Dana Desa

A. Pendahuluan ……......................................................... 78

B. Mekanisme Pengelolaan dan Pertanggungjawaban Dana Desa 81

C. Politik Hukum Penataan Pengelolaan, Pertanggungjawaban dan Pengawasan Dana Desa........... 86

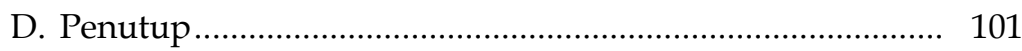

Politik Hukum Pengaturan Penertiban dan Pendayagunaan Tanah Terlantar di Indonesia

A. Pendahuluan 105 
B. Pengaturan dan Prosedur Hukum Penertiban dan Pendayagunaan Tanah Terlantar di Indonesia dan Dampaknya Terhadap Optimalisasi Penggunaan dan Pemanfaatan Tanah di Indonesia

C. Alternatif Politik Hukum Penertiban dan Pendayagunaan Tanah Terlantar di Masa Depan Dalam Rangka Mengurangi Dampak Negatif Dari Pengaturan Penertiban dan Pendayagunaan Tanah Terlantar Saat Ini

D. Penutup

Politik Hukum Zakat, Wakaf dan Ekonomi Syari'ah
A. Pendahuluan 140
B. Regulasi Syari'at Islam dan Ekonomi Syari'ah 142
C. Politik Hukum Zakat, Wakaf, dan Ekonomi Syariah 154
D. Penutup

Politik Hukum Pengaturan Hak Atas Tanah Dalam Penanaman Modal dan Implikasinya Terhadap Kesejahteraan Rakyat
A. Pendahuluan
B. Arah Politik Hukum Pengaturan Hak Atas Tanah Dalam Kegiatan Investasi atau Penanaman Modal di Indonesia..
C. Implikasi Politik Hukum Pertanahan Dalam Upaya Peningkatan Investasi Terhadap Kesejahteraan Ekonomi Rakyat.
D. Penutup 161 167 189

\section{Politik Hukum Investasi Indonesia}

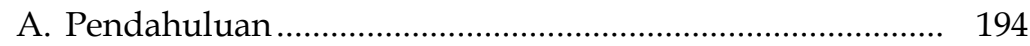

B. Sejarah Hukum Investasi di Indonesia ................................ 197

C. Regulasi Tentang Penanaman Modal ............................... 200

D. Hukum Investasi dalam Kaitannya dengan Perdagangan Internasional .................................................................... 203

E. Arah dan Kebijakan Hukum Investasi Indonesia Pasca Trade Related Investment Measures. 
F. Kepentingan Nasional dan Persoalan Politik Hukum dalam Undang-Undang Nomor 25 Tahun 2007 Tentang Penanaman Modal …….................................................. 210

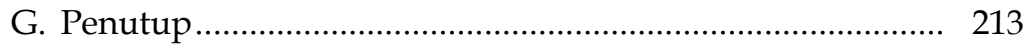

Poltik Hukum Penanggulangan Tindak Pidana Terorisme di Indonesia

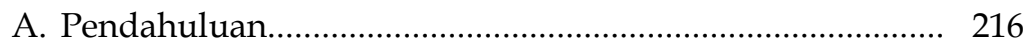

B. Pandangan Umum Politik Hukum .................................. 219

C. Penanggulangan Kejahatan................................................ 223

D. Politik Hukum Penanggulangan Tindak Pidana

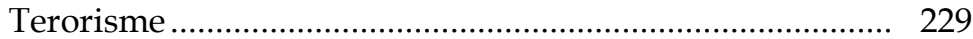

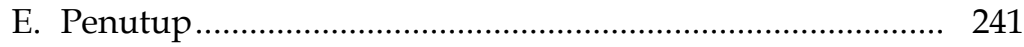




\section{POLITIK HUKUM INDONESIA Teori dan Praktik}




\section{POLITIK HUKUM PEMERINTAH DALAM \\ PEMBERANTASAN KORUPSI DI ERA REFORMASI}

\section{Adam Setiawan}

Dosen Fakultas Hukum, Universitas 17 Agustus 1945 Samarinda J1. Ir. H. Juanda, No.80, Air Hitam, Samarinda, Kalimantan Timur. Email: Adamsetiawanmunif@gmail.com

\section{A. Pendahuluan}

Pemberantasan korupsi merupakan suatu keniscayaan yang harus dipertahankan, karena mengingat praktik korupsi masih saja menyeruak eksis di berbagai sektor. Pendidikan di korupsi, kesehatan dikorupsi, biaya haji dikorupsi, pengadaan pangan dikorupsi. Tidak ada satu bidangpun yang terbebas dari penyakit korupsi. ${ }^{1}$ Kecenderungan tersebut implikasi dari kekuasaan yang sukar atau tidak mau untuk diawasi, sehingga tidak terhindarkan peningkatan praktik korupsi di berbagai sektor. Seakan membenarkan ungkapan populer dari Lord Acton "power tends to corrupt and absolute power corrupts absolutely", kekuasaan cenderung untuk selalu disalahgunakan.

Korupsi mempunyai implikasi yang kuat terhadap keberlangsungan suatu negara. Hal demikian didukung dalam pernyataan Mukadimah United Nations Convention Against Corruption (UNCAC), bahwa "Corruption is an insidious plague that has a wide range of corrosive effects on societies. It undermines democracy and the rule of law, leads to violations of human rights, distorts markets, erodes the quality of life and allows organized crime, terrorism and other threats to human security to flourish" ${ }^{2}$

Berdasarkan Corupption Perceptions Index 2019, Indonesia berada di skor 40/100 dan berada di peringkat 85 dari 180 negara negara yang disurvei. Skor ini meningkat 2 poin dari

1 Denny Indrayana, Jangan Bunuh KPK: Kajian Hukum Tata Negara Penguatan Komisi Pemberantasan Korupsi, (Malang: Intrans Publishing, 2016), hlm. 1

2 Lihat Mukadimah Paragraf 1 United NationsConvention Against Corruption 2003. 
tahun 2018 lalu. Berikut data yang dirilis oleh Transparency International Indonesia: ${ }^{3}$

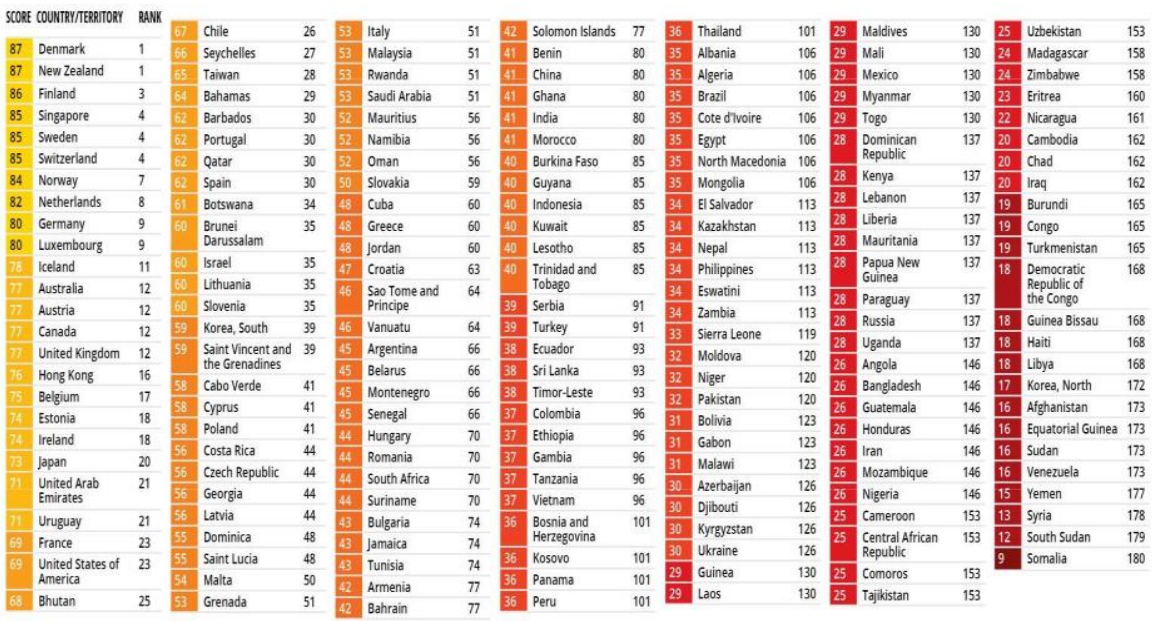

Sumber: Transparency International Indonesia

Kendati data yang dirilis oleh Transparency International Indonesia menunjukan indeks persepsi korupsi negara Indonesia mengalami kemajuan, namun agenda pemberantasan korupsi harus tetap dilakukan secara "kontinu" baik melalui tindakan preventif maupun represif. Mengapa demikian?, seperti yang dikemukakan sebelumnya bahwa korupsi telah marasuk berbagai sektor. Bahkan dewasa ini berkembang opini publik bahwa korupsi sudah menjelma menjadi suatu budaya baru, dalam arti telah menguasai tingkah laku (behavior) bukan saja birokrasi negara tetapi juga dunia usaha dan seluruh lapisan masyarakat, tingginya angka korupsi merugikan kepentingan pembangunan secara keseluruhan. Hampir disetiap bagian kehidupan, selalu ada praktik korupsi. mulai dari bawahan sampai atasan, dari pejabat sampai pegawai rendahan, di bidang perdagangan, dibidang pemerintahan,

3 Lihat Transparency International Indonesia, chrome extension:// oemmndcbldboiebfnladdacbdfmadadm/https://riset.ti.or.id/wpcont ent/uploads/2020/01/map-CPI-2019.pdf, (diakses 4 Juni 2020). 
bahkan dalam bidang pendidikan pun terlihat praktik-praktik korupsi. ${ }^{4}$

Korupsi sangat dipengaruhi oleh perilaku masyarakat. Masyarakat yang hidupnya normal, menerima apa adanya dalam kehidupan sehari-hari alias kurang mendapatkan tekanan-tekanan sosial, ekonomi dan politik yang berat akan lebih terbebas dari perilaku korupsi. Sedangkan, masyarakat yang tinggi tekanan sosial, ekonomi dan politik, akan lebih mudah melakukan tindakan-tindakan korupsi. Mentalitas ingin cepat kaya, ingin cepat sukses, bergaya instan akan rawan berperilaku korup ketimbang masyarakat yang mencintai hasil lewat proses kerja yang matang. ${ }^{5}$

Jika persoalannya adalah korupsi sarat akan pengaruh perilaku masyarakat, memberikan label secara tidak langsung bahwa masyarakat Indonesia memiliki perilaku koruptif, rasanya layak menjustifikasi korupsi adalah budaya yang mengakar di masyarakat Indonesia. Namun persepsi demikian bisa saja dibantah dengan argumentasi yang merujuk pada realitas politik. Sejumlah peneliti menilai akar persoalan korupsi di Indonesia ada pada persoalan politik. Alina Maungiu-Pippidi yang mengeritik program pemberantasan korupsi yang berkutat pada persoalan teknis manajemen sektor publik. Program-program pemberantasan korupsi secara alamiah adalah program yang apolitis, padahal korupsi adalah persoalan politik. ${ }^{6}$

Beralih dari persoalan akar korupsi, pada dasarnya upaya pemberantasan korupsi harus dilakukan oleh segenap stakeholder dan melibatkan berbagai elemen masyarakat. Namun ikhtiar tersebut bukan tanpa tantangan, sebut saja isu yang masih hangat (hot issue) yakni serangan legislasi terhadap Komisi Pemberantasan Korupsi (selanjutnya disebut KPK),

4 Samsul Tamher, Penyidikan Tindak Pidana Korupsi Di Wilayah Hukum Kejaksaan Tinggi Papua, (Disertasi, Program Doktor Ilmu Hukum Universitas Hasanuddin Makassar, 2018), hlm. 8.

5 Ibid.

6 Donal Fariz, "Pemerintahan Joko Widodo dan Serangan Politik Terhadap KPK", Jurnal Integrasi, Volume. 5, Nomor 2, 2019, hlm. 22. 
yang di antaranya berimplikasi pada perubahan format kedudukan KPK dalam sistem ketatanegaraan yang semula merupakan lembaga independen tidak masuk dalam lingkup kekuasaan manapun (legislatif, eksekutif dan yudikatif) kini menjadi lingkup dari eksekutif.7Perubahan terhadap format kedudukan KPK merupakan tindak lanjut dari Putusan Mahkamah Konstitusi Nomor 36/PUU-XV/2017. Dalam pertimbanganya Mahkamah Konstitusi berpendapat sebagai berikut. $^{8}$

Jika dicermati, dalam Konsiderans menimbang huruf $b$ Undang-Undang Nomor 30 Tahun 2002 tentang Komisi Pemberantasan Tindak Pidana Korupsi (selanjutnya disebut UU KPK) dinyatakan: bahwa lembaga pemerintah yang menangani perkara tindak pidana korupsi belum berfungsi secara efektif dan efisien dalam memberantas tindak pidana korupsi. Berpijak dari Konsiderans tersebut, yang dimaksud sebagai lembaga pemerintah yang dalam hal ini menangani perkara tindak pidana korupsi ialah Kepolisian dan Kejaksaan. Hal ini dapat diketahui dengan mengingat bahwa tugas penyelidikan, penyidikan, atau penuntutan terhadap pelaku tindak pidana korupsi merupakan kewenangan Kepolisian dan/atau Kejaksaan. Dengan demikian, dasar pembentukan KPK ialah karena belum optimalnya lembaga negara in casu Kepolisian dan Kejaksaan yang mengalami public distrust dalam pemberantasan tindak pidana korupsi. dalam rangka mengembalikan kepercayaan masyarakat terhadap penegakan hukum, dibentuklah KPK. Dalam konstruksi demikian, secara tugas dan fungsi, Kepolisian, Kejaksaan, dan KPK

7 Lihat Pasal 3 Undang-Undang Nomor 19 Tahun 2019 tentang Perubahan Kedua Atas Undang-Undang Nomor 30 Tahun 2002 tentang Komisi Pemberantasan Tindak Pidana Korupsi, menyebutkan Komisi Pemberantasan Korupsi adalah lembaga negara dalam rumpun kekuasaan eksekutif yang dalam melaksanakan tugas dan wewenangnya bersifat independen dan bebas dari pengaruh kekuasaan manapun.

8 Putusan Mahkamah Konstitusi Nomor 36/PUU-XV/2017 tentang Pengujian Undang-Undang Nomor 17 Tahun 2014 tentang Majelis Permusyawaratan Rakyat, Dewan Perwakilan Rakyat, Dewan Perwakilan Daerah, dan Dewan Perwakilan Rakyat Daerah, hlm. 108. 
merupakan lembaga yang berada di ranah eksekutif. Bahkan lebih lanjut, tugas utama KPK sebagaimana dinyatakan dalam Pasal 6 ialah melakukan koordinasi dan supervisi terhadap instansi yang berwenang melakukan pemberantasan tindakan pidana korupsi dalam hal ini menjadi trigger mechanism bagi Kepolisian dan Kejaksaan. Mengacu pada pendapat Saskia Lavrijssen, 2008, KPK merupakan lembaga penunjang yang terpisah atau bahkan independen, dari departemen eksekutif, akan tetapi sebenarnya "eksekutif". Dalam pandangan Mahkamah, KPK sebenarnya merupakan lembaga di ranah eksekutif, yang melaksanakan fungsi-fungsi dalam domain eksekutif, yakni penyelidikan, penyidikan, dan penuntutan. KPK jelas buka di ranah yudikatif, karena bukan badan pengadilan yang berwenang mengadili dan memutus perkara. KPK juga bukan badan legislatif karena bukan organ pembentuk undang-undang.

Benar bahwa KPK merupakan lembaga negara yang dalam melaksanakan tugas dan wewenangnya bersifat independen dan bebas dari pengaruh kekuasaan manapun. Posisinya yang berada di ranah eksekutif, tidak berarti membuat KPK tidak independen dan terbebas dari pengaruh manapun. Dalam Putusan Mahkamah Konstitusi Nomor 012-016-019/PUU-IV/2006 pada halaman 269 dinyatakan, independensi dan bebasnya KPK dari pengaruh kekuasaan manapun adalah dalm melaksanakan tugas dan wewenangnya.

Selain itu, tantangan pemberantasan korupsi dapat dilihat dari proses rekrutmen pimpinan KPK. Dalam hal ini Pimpinan KPK bukan merupakan sumber daya yang terbaik yang dihasilkan dari proses rekrutmen. Hal demikian terasa dalam rekrutmen Pimpinan KPK generasi ke lima, dibuktikan dari berbagai penolakan yang datang dari berbagai elemen masyarakat (akedemisi, NGO, dll). Penolakan terhadap kandidat Pimpinan KPK dilatarbelakangi beberapa hal. ${ }^{9}$

9 Adam Setiawan, "Mengakhiri Polemik Capim KPK", https://news.detik.com/kolom/d-4691642/mengakhiri-polemik-capim-kpk, (diakses 4 Juni 2020). 
Pertama, disinyalir adanya dugaan kuat conflict of interest antara salah satu Pansel (Panitia Seleksi) dengan salah satu kandidat yang berasal dari institusi tertentu. Adanya conflict of interest demikian tentu telah bertentangan secara moral sehingga berimplikasi terhadap objektivitas proses seleksi. Di samping itu pula yang menjadi kekhawatiran dan kecemasan publik adalah tatkala ada salah satu Pansel dekat dengan salah satu lembaga tertentu karena tidak menutup kemungkinan hadirnya agenda kepentingan yang terselubung sehingga nantinya akan berpengaruh pada efektivitas proses pemberantasan korupsi.

Kedua, berdasarkan realitas yang ada dapat dikatakan bahwa proses seleksi Capim KPK yang berlangsung tidak dilaksanakan secara transaparan. Beberapa masukan dan rekomendasi terkait pelaksanaan seleksi tidak diindahkan oleh Pansel KPK. Salah satu tanggapan publik adalah "jangan meloloskan kandidat yang bermasalah". Padahal jika merujuk Pasal 31 UU KPK secara expressis verbis telah disebutkan bahwa proses pencalonan dan pemilhan Anggota KPK dilakukan secara transparan. Selain itu masyarakat mempunyai ruang untuk menyampaikan tanggapannya, sebagaimana disebutkan dalam Pasal 30 ayat (6), bahwa Panitia seleksi mengumumkan kepada masyarakat untuk mendapatkan tanggapan terhadap nama calon sebagaimana dimaksud pada ayat (4). Dan Pasal 30 ayat (7): Tanggapan sebagaimana dimaksud pada ayat (6) disampaikan kepada panitia seleksi paling lambat 1 (satu) bulan terhitung sejak tanggal diumumkan.

Ketiga, Pansel dengan santainya meloloskan Calon Komisioner KPK yang tidak melampirkan LHKPN (Laporan Harta Kekayaan Penyelenggara Negara) khususnya kandidat yang berasal dari Penyelenggara Negara. Ketua Pansel Capim KPK Yenti Garnasih beranggapan bahwa para peserta calon komisioner KPK tidak mempunyai kewajiban untuk melampirkan LHKPN dalam proses seleksi. LHKPN baru wajib diserahkan atau dilaporkan setelah terpilih menjadi pimpinan KPK. Pemahaman demikian tentunya misleading jika merujuk 
normanya sebagaimana Pasal 29 huruf k UU No 30/2002 secara eksplisit menyebutkan bahwa untuk dapat diangkat sebagai Pimpinan Komisi Pemberantasan Korupsi harus memenuhi persyaratan yakni mengumumkan kekayaannya sesuai dengan peraturan perundang-undangan yang berlaku. Dalam Pasal 5 ayat (3) Undang-Undang Nomor 28 Tahun 1999 juga disebutkan secara eksplisit bahwa setiap Penyelenggara Negara berkewajiban untuk melaporkan dan mengumumkan kekayaan sebelum dan setelah menjabat.

Berdasarkan uraian di atas dapat ditarik inti persoalan pemberantasan korupsi adalah masih adanya campur tangan kekuatan politik (political interference) baik itu pemerintah (eksekutif) maupun di Dewan Perwakilan Rakyat (legislatif). Ironi berbagai kepentingan bersatu bukan untuk memperkuat pemberantasan korupsi melainkan untuk mendelegitimasi upaya pemberantasan korupsi yang dilakukan oleh KPK.

Dukungan politik terhadap upaya pemberantasan korupsi merupakan suatu keniscayaan, sebagaimana dikatakan John S.T. Quah

"Political will is perphaps the most important precondition for the effectiveness of an ACA". Political will refers to the commitment of political leaders to eradicate corruption and existswhen these three conditions are met: (1) comprehensive anti-corruption legislation exists;(2) the independent ACA is provided with sufficient personnel and resources; and (3) the anti-corruption laws are fairly enforced by the independent ACA. Indeed, political will is "the most important prerequisite as a comprehensive anti-corruptionstrategy will fail if it is not supported by the political leadership in a country". Thus, the commitment of the political leaders in fighting corruption ensuresthe allocation of adequate personnel and resources to the anti-corruption effort, and theimpartial enforcement of the anti-corruption laws by the ACA. ${ }^{10}$ Denny Indrayana sependapat dengan pandangan John S.T. Quah. Karena

10 John S.T. Quah, “Anti-Corruption Agencies In Four Asian Countries: A Comparative Analysis", International Public Management Review, Volume 8, Issue 2, 2007, hlm. 89. 
faktanya, sekuat apapun komisi antikorupsi, secara regulasi, secara kewenangan dan lain sebagainya, namun semua itu menjadi tidak ada artinya jika pada realitanya para pemimpin negeri tidak mendukung kerja-kerja pemberantasan korupsi. ${ }^{11}$

Adapun yang dikemukakan oleh John S.T. Quah, dengan kata lain pemberantasan korupsi tidak hanya digantungkan pada KPK. Namun lebih pada tataran penegakan hukum dalam arti luas yang dalam hal ini merujuk peran krusial aktor politik di parlemen maupun di pemerintah karena merekalah yang menciptakan produk hukum khususnya yang berkaitan langsung terhadap pemberantasan korupsi. Dengan demikian dapat dikatakan keberhasilan upaya pemberantasan korupsi harus disertai dukungan politik melalui produk hukumnya. Dalam hal ini politik dan hukum bersifat koheren. Prof. Sri Soemantri pernah mengonstatasi hubungan antara hukum dan politik di Indonesia ibarat perjalanan lokomotif kereta api yang keluar dari relnya. Jika hukum diibaratkan rel dan politik diibaratkan lokomotif maka sering terlihat lokomotif itu keluar dari rel yang seharusnya dilalui. ${ }^{12}$

Lebih lanjut, prinsip (atau sekedar semboyan) yang menyatakan politik dan hukum harus bekerja sama dan saling menguatkan melalui ungkapan "hukum tanpa kekuasaan adalah angan-angan, kekuasaan tanpa hukum adalah kelaliman menjadi semacam utopi belaka. ${ }^{13}$

Miro Cerar mengambarkan hubungan politik dan hukum sebagai

"The relation between politics and law has both a progressive function and a safeguarding function. Law and politics, separately or together, both encourage and suppress the

11 Denny Indrayana, op.cit, hlm. 73.

12 Sri Soemantri Martosuwignjo, "Pembangunan Hukum Nasional dalam Perspektif Kebijakasanaan" makalah untuk Praseminar Identitas Hukum Nasional di Fakultas Hukum Yogyakarta, 19-21 Oktober 1987 lihat Moh. Mahfud MD, Politik Hukum di Indonesia, (Jakarta: Rajawali Pers, 2017), hlm. 21.

13 Ibid. 
development of societal relations, while they both also function to bring about justice and order." 14

Berdasarkan pendapat Miro Cerar terlihat bahwa politik dan hukum mempunyai hubungan yang tidak terpisahkan dilihat dari fungsi dan pengaruhnya terhadap perkembangan masyarakat. Berdasarkan latar belakang yang dikemukan di atas, maka fokus riset yang dilakukan dalam tulisan ini adalah bagaimana Politik Hukum Pemerintah dalam Pemberantasan Korupsi di Indonesia?

\section{B. Relasi Hukum dan Politik}

Sebelum menelusuri politik hukum Pemerintah dalam pemberantasan korupsi, rasanya perlu memahami relasi antara hukum dan politik secara holistik. Politik dapat dipahami sebagai kekuasaan terutama kekuasaan untuk menentukan kebijakan publik. ${ }^{15}$ Berkaitan dengan kekuasaan, Peter Markl mengemukakan bahwa politik dalam bentuk yang paling buruk, adalah perebutan kekuasaan, kedudukan, dan kekayaan untuk kepentingan diri sendiri (politics at its worst is a selfish grab for power, glory and riches). ${ }^{16}$ Pandangan lain dikemukakan oleh Rod Hague bahwa politik adalah kegiatan yang menyangkut cara bagaimana kelompok-kelompok mencapai keputusankeputusan yang bersifat kolektif dan mengikat melalui usaha untuk mendamaikan perbedaan-perbedaan di antara anggotaanggotanya (politics is the activity by which groups reach binding collective decisions through attempting to reconcile differences among their members). ${ }^{17}$

Berdasarkan pengertian yang dikemukakan oleh para Ahli dapat dipahami makna politik sebagai suatu kekuasaan

14 Miro Cerar, "The Relationship Between and Politics", Annual Survey of International \& Comparative Law, Volume 15, Issue 1, 2009, hlm. 3.

15 Pandangan tersebut berasal dari para sarjana-sarjana dari Mahzab Chicago (Chicago School) antara lain tersebut nama Charles E. Merriam dengan karyanya Political Power. Its Composition and Incidence (1934), dan Harold D Laswell dengan bukunya Politics: Who Gets What, When How (1936). Lihat Miriam Budiardjo hlm.73.

16 Ibid.

17 Ibid. 
yang mempunyai pengaruh besar terhadap publik. Dalam hal ini bisa kita lihat bagaimana "kekuasaan" mempunyai hak untuk menentukan berbagai kebijakan yang tentunya memberikan dampak terhadap masyarakat. Oleh karena itu masyarakat mau tidak mau harus mengikuti dan mematuhi segala kebijakan yang dibuat oleh penguasa.

Menurut Sudikno Mertokusumo yang dapat memberi atau memaksakan sanksi terhadap pelanggaran kaidah hukum adalah penguasa, karena penegakan hukum dalam hal pelanggaran adalah monopoli penguasa. Penguasa mempunyai kekuasaan untuk memaksakan sanksi terhadap pelanggaran kaidah hukum. Hakikat kekuasaan tidak lain adalah kemampuan seseorang untuk memaksakan kehendaknya kepada orang lain. ${ }^{18}$

Hukum ada karena kekuasaan yang sah. Karena kekuasaan yang sahlah yang menciptakan hukum. Ketentuan-ketentuan yang tidak berdasarkan kekuasaan yang sah pada dasarnya bukanlah hukum. Jadi hukum bersumber pada kekuasaan yang sah. ${ }^{19}$ Menurut Satjipto Rahardjo hukum membutuhkan kekuasaan, tetapi ia juga tidak bisa membiarkan kekuasaan itu menunggangi hukum. Dengan pengutaraan seperti itu kita melihat dengan jelas persoalan yang kita hadapi sekarang, yaitu, hubungan antara hukum dan kekuasaan.

Menurut Moh. Mahfud MD dalam tulisan yang berjudul "Mengefektifkan Kontrol Hukum Atas Kekuasaan" ada pandangan bahwa hukum dan kekuasaan itu tidaklah tunggal. Antara kaum idealis yang berorientasi pada das sollen dan kaum empiris yang lebih melihat hukum sebagai das sein memberikan pandangan berbeda. Namun pengamat kedua pandangan itu sama-sama sependapat bahwa seharusnya hukum itu supreme atas kekuasaan. Ada dua model bingkai mengenai hubungan hukum dan kekuasaan, yaitu: pertama, hukum menentukan dan mempengaruhi kekuasaan (politik) yang menyertai wawasan

18 Sudikno Mertokusumo, Mengenal Hukum: Suatu Pengantar, (Yogyakarta: Cahaya Atma Pustaka, 2010), hlm. 25.

19 Satjipto Rahardjo, Ilmu Hukum, Cetakan VII, (Bandung: Citra Aditya Bakti, 2014), hlm. 145 
negara hukum yang das sollen; kedua, hukum dipengaruhi, ditentukan, bahkan diintervensi oleh politik seperti yang sering terlihat di dalam kenyataan empirik yang das sein. ${ }^{20}$

Dalam tulisan lain, Moh. Mahfud MD menjelaskan hubungan kausalitas antara hukum dan politik atau pertanyaan tentang apakah hukum yang memengaruhi hukum, maka paling tidak ada tiga macam jawaban yang menjelaskannya. Pertama, hukum determinan atas politik dalam arti bahwa kegiatan-kegiatan politik diatur oleh dan harus tunduk pada aturan-aturan hukum. Kedua, politik determinan atas hukum karena hukum merupakan hasil berinteraksi dan (bahkan) saling bersaingan. Ketiga, politik dan hukum sebagai subsistem kemasyaakatan berada pada posisi derajat determinasinya seimbang antara yang satu dengan yang lain karena meskipun hukum merupakan produk keputusan politik, tetapi begitu hukum ada maka semua kegiatan politik harus tunduk pada aturan-aturan hukum. ${ }^{21}$ Pada intinya politik dan hukum harus bekerja sama dan saling menguatkan melalui ungkapan "hukum tanpa kekuasaan adalah angan-angan, kekuasaan tanpa hukum adalah kelaliman menjadi semacam utopi belaka.

\section{Definisi Politik Hukum}

Sejauh ini tidak ada keseragaman di antara para ahli hukum di Indonesia dalam mendefinisikan politik hukum. Padmo Wahjono memberikan definisi politik hukum sebagai kebijakan dasar yang menentukan arah, bentuk, maupun isi hukum yang dibentuk. ${ }^{22}$ Definisi politik hukum dielaborasi kembali oleh Padmo Wahjono dalam tulisannya yang berjudul "Menyelisik Proses Terbentuknya Perundang-undangan", disebutkan bahwa politik hukum sebagai kebijakan penyelenggara negara tentang apa yang dijadikan kriteria

20 Moh. Mahfud MD, "Mengefektifkan Kontrol Hukum Kekuasaan", Jurnal Ius Quia Iustum, Volume. 3, Nomor 6, 1996, hlm. 8.

21 Mahfud MD, Politik Hukum.., op.cit, hlm. 16.

22 Padmo Wahjono, Indonesia Negara Berdasarkan Atas Hukum, (Jakarta: Ghalia Indonesia, 1986), hlm. 160. 
untuk menghukumkan sesuatu yang di dalamnya mencakup pembentukan, penerapan, dan penegakan hukum. ${ }^{23}$

Mochtar Kusumaatmadja ${ }^{24}$ memaknai politik hukum sebagai kebijakan hukum dan perundang-undangan dalam pembaharuan hukum. Instrumen politik dilakukan melalui peraturan perundang-undangan. Namun instrumen perundang-undangan menghadapi masalah, pertama, kesulitan untuk secara rasional dan pasti menetapkan prioritas yang sesuai dengan kebutuhan masyarakat, dan kedua, untuk membuat hukum yang sesuai dengan kebutuhan dan kesadaran hukum masyarakat intisari pemikiran politik hukum yang dikemukakan oleh Mochtar Kusumaatmadja adalah berkaitan dengan hukum mana yang perlu dibentuk (diperbaharui, diubah, atau diganti) dan hukum mana yang perlu dipertahankan agar secara bertahap dapat diwujudkan tujuan negara.

Abdul Hakim Garuda Nusantara memberikan pengertian politik hukum sebagai kebijakan hukum (legal policy) yang hendak diterapkan atau dilaksanakan secara nasional oleh suatu pemerintahan negara tertentu. politik hukum nasional bisa meliputi:

1. Pelaksanaan ketentuan hukum yang telah ada secara konsisten;

2. Pembangunan Hukum yang intinya adalah pembaruan terhadap ketentuan hukum yang telah ada dan yang dianggap usang, dan penciptaan ketentuan hukum yang baru yang diperlukan untuk memenuhi tuntutan perkembangan yang terjadi dalam masyarakat;

3. Penegasan fungsi lembaga penegak atau pelaksana hukum dan pembinaan anggotanya;

23 Padmo Wahjono, "Menyelisik Proses Terbentuknya Peraturan Perundang-undang dalam Majalah Forum Keadilan, Nomor 29, April 1991, hlm. 65.

24 Mochtar Kusumaatmadja, Konsep-konsep Hukum dalam Pembangunan: Kumpulan Karya Tulis Prof. Dr. Mochtar Kusumaatmadja, S.H., LL.M, (Bandung: Alumni, 2002), hlm. 3-4. 
4. Meningkatkan kesadaran hukum masyarakat menurut persepsi kelompok elit pengambil kebijakan. ${ }^{25}$

Dari berbagai pengertian dan definisi itu, dengan mengambil substansinya yang ternyata sama, Moh. Mahfud MD mengemukakan bahwa politik hukum adalah "legal policy atau garis (kebijakan) resmi tentang hukum yang akan diberlakukan baik dengan pembuatan hukum baru maupun dengan penggantian hukum lama, dalam rangka mencapai tujuan negara." Dengan demikian, politik hukum merupakan pilihan tentang hukum-hukum yang diberlakukan sekaligus pilihan tentang hukum-hukum yang akan dicabut atau tidak diberlakukan yang kesemuanya dimaksudkan untuk mencapai tujuan negara seperti yang tercantum di dalam pembukaan UUD 1945 (Undang-Undang Dasar Negera Republik Indonesia). ${ }^{26}$

Dalam konteks pemberantasan korupsi, Muh. Risnain memberikan definisi politik hukum pemberantasan korupsi adalah kebijakan hukum yang diambil oleh negara melalui organ-organ negara yaitu legislatif dan eksekutif melalui peraturan perundang-undangan mengenai arah hukum yang diberlakukan untuk mencapai tujuan pemberantasan korupsi berupa kebijakan pembuatan hukum baru dan penggantian hukum lama. ${ }^{27}$ Adapun pendapat Muh Risnain, dalam hal ini dapat mempermudah untuk menganalisa sejauh mana semangat pemberantasan korupsi pemerintah ditinjau dari kebijakan hukum yang diambil oleh pemerintah. Apakah kebijakan hukum yang diambil merupakan kebijakan hukum yang pro terhadap pemberantasan korupsi atau sebaliknya.

25 Abdul HakimGaruda Nusantara " Politik Hukum Nasional”, makalah disampaikan pada Karya Latihan Bantuan Hukum (KALABAHU), diselenggarakan Yayasan LBH Indonesia dan LBH Surabaya, September 1985.

26 Moh. Mahfud MD, Politik Hukum.., op.cit, hlm. 1.

27 Muh. Risnain, "Kesinambungan Politik Hukum Pemberantasan Korupsi “, Jurnal Rechtsvinding, Volume, Nomor 3, 2014, hlm. 317. 


\section{Politik Hukum Pemberantasan Korupsi}

1. Ketetapan MPR No XI/MPR/1998 Tahun 1998 Tentang Penyelenggara Negara Yang Bersih dan Bebas Korupsi, Kolusi dan Nepotisme.

Pasca runtuhnya rezim Orde Baru dan bergulirnya era reformasi berbagai tuntutan publik mencuat, antara lain mempertegas upaya pemberantasan korupsi kolusi dan nepotisme (disingkat $\mathrm{KKN}$ ) mengingat menjamurnya praktik KKN yang dilakukan oleh para penyelenggara negara saat itu. Berdasarkan Ketetapan MPR No XI/MPR/1998 Tahun 1998 Tentang Penyelenggara Negara Yang Bersih dan Bebas Korupsi, Kolusi dan Nepotisme disebutkan bahwa penyelenggara negara pada lembaga-lembaga eksekutif, legislatif, dan yudikatif harus melaksanakan fungsi dan tugasnya dengan baik dan bertanggung jawab kepada masyarakat, bangsa dan negara. ${ }^{28}$

Selama menjalankan fungsi dan tugasnya, penyelenggara negara harus jujur, adil, terbuka, dan terpercaya serta mampu membebaskan diri dari praktek korupsi, kolusi dan nepotisme. ${ }^{29}$ Untuk menghindarkan praktek-praktek korupsi, kolusi dan nepotisme, seseorang yang dipercaya menjabat suatu jabatan dalam penyelenggaraan negara harus bersumpah sesuai dengan agamanya, harus mengumumkan dan bersedia diperiksa kekayaannya sebelum dan setelah menjabat. ${ }^{30}$ Pemeriksaan terhadap kekayaan tersebut dilakukan oleh suatu lembaga yang dibentuk oleh Kepala Negara yang keanggotaannya terdiri dari pemerintah dan masyarakat.

Upaya pemberantasan korupsi, kolusi, dan nepotisme harus dilakukan secara tegas terhadap siapapun juga, baik

28 Pasal 2 ayat (1) Ketetapan MPR No XI/MPR/1998 Tahun 1998 Tentang Penyelenggara Negara Yang Bersih dan Bebas Korupsi, Kolusi dan Nepotisme.

${ }_{29}$ Pasal 2 ayat (2) Ketetapan MPR No XI/MPR/1998 Tahun 1998 Tentang Penyelenggara Negara Yang Bersih dan Bebas Korupsi, Kolusi dan Nepotisme.

30 Pasal 3 ayat (1) Ketetapan MPR No XI/MPR/1998 Tahun 1998 Tentang Penyelenggara Negara Yang Bersih dan Bebas Korupsi, Kolusi dan Nepotisme. 
pejabat negara, mantan pejabat negara, keluarga, kroninya maupun pihak swasta/konglomerat termasuk mantan Presiden Soeharto dengan tetap memperhatikan prinsip praduga tak bersalah dan hak-hak asasi manusia. ${ }^{31}$

2. Ketetapan MPR No. VIII/MPR/RI Tahun 2001 tentang Rekomendasi Arah Kebijakan Pemberantasan dan Pencegahan Korupsi.

Adapun Ketetapan MPR No XI/MPR/1998 Tahun 1998 merupakan komitmen awal pemerintah kala itu dalam memperkuat upaya pemberantasan korupsi, kolusi dan nepotisme pasca runtuhnya rezim Orde Baru. Melalui Ketetapan MPR No. VIII/MPR/RI Tahun 2001 tentang Rekomendasi Arah Kebijakan Pemberantasan dan Pencegahan Korupsi. Rekomendasi arah kebijakan ini dimaksudkan untuk mempercepat dan lebih menjamin efektivitas pemberantasan korupsi, kolusi, dan nepotisme sebagaimana diamanatkan dalam Ketetapan Majelis Permusyawaratan Rakyat Indonesia Nomor XI/MPR/1998 tentang Penyelenggara Negara yang Bersih dan Bebas Korupsi, dan Nepotisme, serta berbagai peraturan perundang-undangan yang terkait. ${ }^{32}$

Arah kebijakan pemberantasan KKN sebagaimana disebutkan dalam Ketetapan MPR No. VIII/MPR/RI Tahun 2001 meliputi: ${ }^{33}$

a. Mempercepat proses hukum terhadap aparatur pemerintah terutama aparat penegak hukum dan penyelenggara negara yang diduga melakukan praktek korupsi, kolusi nepotisme, serta dapat dilakukan tindakan administratif;

31 Pasal 4 Ketetapan MPR No XI/MPR/1998 Tahun 1998 Tentang Penyelenggara Negara Yang Bersih dan Bebas Korupsi, Kolusi dan Nepotisme.

32 Pasal 1 Ketetapan MPR No. VIII/MPR/RI Tahun 2001 tentang Rekomendasi Arah Kebijakan Pemberantasan dan Pencegahan Korupsi.

33 Pasal 2 Ketetapan MPR No. VIII/MPR/RI Tahun 2001 tentang Rekomendasi Arah Kebijakan Pemberantasan dan Pencegahan Korupsi. 
b. Melakukan penindakan hukum yang lebih bersungguh-sungguh terhadap semua kasus korupsi, termasuk korupsi yang telah tejadi di masa lalu, dan bagi mereka yang telah terbukti bersalah agar dijatuhi hukuman yang seberat-beratnya;

c. Mendorong partisipasi masyarakat luas dalam mengawasi dan melaporkan kepada pihak yang berwenang berbagai dugaan praktek korupsi, kolusi, dan nepotisme yang dilakukan oleh pegawai negeri, penyelenggara negara dan anggota masyarakat;

d. Mencabut, mengubah, atau mengganti semua peraturan perundang-undangan serta keputusan-keputusan penyelenggara negara yang berindikasi melindungi atau memungkinkan terjadinya korupsi, kolusi, dan nepotisme;

e. Merevisi semua peraturan perundang-undangan yang berkenaan dengan korupsi sehingga sinkron dan konsisten satu dengan yang lainnya;

f. Membentuk Undang-undang beserta peraturan pelaksanaanya untuk membantu percepatan dan efektivitas pelaksanaan pemberantasan dan pencegahan korupsi yang muatannya meliputi:

1) Komisi Pemberantasan Tindak Pidana Korupsi;

2) Perlindungan Saksi dan Korban;

3) Kejahatan Terorganisasi;

4) Kebebasan mendapatkan Informasi;

5) Etika Pemerintahan;

6) Kejahatan Pencucian Uang;

7) Ombudsman.

Politik hukum pemerintah dalam pemberantasan korupsi telah tertuang dalam beberapa undang-undang antara lain: 1) Undang-Undang Nomor 31 Tahun 1999 tentang Pemberantasan Tindak Pidana Korupsi; 2) Undang-Undang Nomor 20 Tahun 2001 tentang Perubahan Atas Undang-Undang No 31 Tahun 1999 tentang 
Pemberantasan Tindak Pidana Korupsi; 3) Undang-Undang Nomor 30 Tahun 2002 tentang Komisi Pemberantasan Korupsi; 4) Undang-Undang Nomor 19 Tahun 2019 tentang Perubahan Kedua Atas Undang-Undang Nomor 30 Tahun 2002 tentang Komisi Pemberantasan Korupsi; 5) Undang-Undang Nomo 38 Tahun 2008 tentang Ombudsman Republik Indonesia.

3. Undang-undang Nomor 31 Tahun 1999 tentang Pemberantasan Tindak Pidana Korupsi dan Undang-Undang Nomor 20 Tahun 2001 tentang Perubahan Atas Undang-Undang No 31 Tahun 1999 tentang Pemberantasan Tindak Pidana Korupsi.

Praktik korupsi tidak hanya melanda negara-negara berkembang, tetapi juga negar-negara maju seperti Amerika Serikat. Hanya saja korupsi di negara-negara maju tidak separah dengan korupsi di negara-negara berkembang seperti Indonesia. Instrumen dan supermasi hukum pada negar-negara maju dalam memberantas korupsi, betul-betul berjalan sebagaimana mestinya karena adanya keseriusan aparat hukumnya yang didukung oleh kemauan poltik (political will) kepala pemerintahan. Kenyataan sebaliknya di Indonesia, suburnya praktik korupsi terutama saat Orde Baru yang dilanjutkan di era Reformasi, kurang menyentuh perhatian pemerintah (eksekutif) dan wakil rakyat yang ada di parlemen (legislatif). ${ }^{34}$

Sejarah pemberantasan korupsi yang cukup panjang di Indonesia menunjukan bahwa pemberantasan korupsi memang membutuhkan penanganan yang ekstra keras dan membutuhkan kemauan politik yang sangat besar dan serius dari pemerintah yang berkuasa. Politik pemberantasan korupsi itu sendiri tercermin dari peraturan perundang-undangan yang dilahirkan pada periode

34 Marwan Mas, Pemberantasan Tindak Pidana Korupsi, lihat Ruslan Renggong, Hukum Pidana Khusus: Memahami Delik-delik di Luar KUHP, (Jakarta: Kencana, 2016), hlm. 59. 
pemerintahan tertentu. Lahirnya undang-undang yang secara khusus mengatur mengenai pemberantasan tindak pidana korupsi sesungguhnya tidaklah cukup untuk untuk menunjukan keseriusan atau komitmen pemerintah. Perlu dari sekedar melahirkan suatu peraturan perundang-undangan, yaitu menerapkan ketentuan yang diatur di dalam undang-undang dengan cara mendorong aparat penegak hukum yang berwenang untuk memberantas korupsi dengan cara-cara yang tegas, berani, dan tidak pandang bulu. ${ }^{35}$

Bertalian dengan apa yang dikemukakan sebelumnya, sejatinya aparat penegak hukum memerlukan payung hukum (umbrella act) dalam upaya penegakan hukum (law enforcement) khususnya pemberantasan tindak pidana korupsi. Dalam hal ini landasan hukum mengenai pemberantasan tindak pidana korupsi sebagaimana telah diamanatkan Ketetapan MPR No XI/MPR/1998 Tahun 1998 Tentang Penyelenggara Negara Yang Bersih dan Bebas Korupsi, Kolusi dan Nepotisme, diatur dalam Undang-undang Nomor 31 Tahun 1999 tentang Pemberantasan Tindak Pidana Korupsi (selanjutnya disebut UU Tipikor) dan Undang-Undang Nomor 20 Tahun 2001 tentang Perubahan Atas Undang-Undang No 31 Tahun 1999 tentang Pemberantasan Tindak Pidana Korupsi (Revisi UU Tipikor).

Berdasarkan konsideran UU Tipikor disebutkan bahwa tindak pidana korupsi sangat merugikan keuangan negara atau perekonomian negara dan menghambat pembangunan nasional, sehingga harus diberantas dalam ruang mewujudkan masyarakat adil dan makmur berdasarkan Pancasila dan Undang-Undang Dasar 1945. Akibat tindak pidana korupsi yang terjadi selama ini selain merugikan keuangan negara dan perekonomian negara, 
juga menghambat pertumbuhan dan kelangsungan pembangunan nasional yang menuntut efisiensi tinggi. ${ }^{36}$

Selanjutnya, dibentuknya undang-undang a quo menimbang Undang-undang Nomor 3 Tahun 1971 tentang Pemberantasan Tindak Pidana Korupsi sudah tidak sesuai lagi dengan perkembangan kebutuhan hukum dalam masyarakat, karena itu perlu diganti dengan Undang-undang Pemberantasan Tindak Pidana Korupsi yang baru sehingga diharapkan lebih efektif dalam mencegah dan memberantas korupsi. ${ }^{37}$

Pada perkembangannya, tindak pidana korupsi yang selama ini terjadi secara meluas, tidak hanya merugikan keuangan negara, tetapi juga telah merupakan pelanggaran terhadap hak-hak sosial dan ekonomi masyarakat secara luas, sehingga tindak pidana korupsi perlu digolongkan sebagai kejahatan yang pemberantasannya harus dilakukan secara luar biasa. ${ }^{38}$ Untuk lebih menjamin kepastian hukum, menghindari keragaman penafsiran hukum dan memberikan perlindungan terhadap hak-hak sosial dan ekonomi masyarakat, serta perlakuan secara adil dalam memberantas tindak pidana korupsi, perlu diadakan perubahan atas Undang-undang Nomor 31 Tahun 1999 tentang Pemberantasan Tindak Pidana Korupsi. ${ }^{39}$

Subjek hukum tindak pidana korupsi telah diatur secara jelas dalam UU Tipikor sebagai berikut: ${ }^{40}$

36 Lihat dalam Menimbang huruf a dan b Undang-undang Nomor 31 Tahun 1999 Republik Indonesia Tentang Pemberantasan Tindak Pidana Korupsi.

37 Lihat dalam Menimbang huruf c Undang-undang Nomor 31 Tahun 1999 Republik Indonesia Tentang Pemberantasan Tindak Pidana Korupsi.

38 Lihat dalam Menimbang huruf a Undang-Undang Nomor 20 Tahun 2001 tentang Perubahan Atas Undang-Undang No 31 Tahun 1999 tentang Pemberantasan Tindak Pidana Korupsi.

39 Lihat dalam Menimbang huruf c Undang-Undang Nomor 20 Tahun 2001 tentang Perubahan Atas Undang-Undang No 31 Tahun 1999 tentang Pemberantasan Tindak Pidana Korupsi.

40 Pasal 1 Undang-Undang Nomor 20 Tahun 2001 tentang Perubahan Atas Undang-Undang No 31 Tahun 1999 tentang Pemberantasan Tindak Pidana Korupsi. 
a. Korporasi adalah kumpulan orang dan atau kekayaan yang terorganisasi baik merupakan badan maupun bukan badan hukum.

b. Pegawai Negeri adalah meliputi:

1) pegawai negeri sebagaimana undang-undang tentang kepegawaian;

2) pegawai negeri sebagaimana dimaksud dalam kitab undang-undang hukum pidana;

3) orang yang menerima gaji atau upah dari keuangan negara atau daerah;

4) orang yang menerima gaji atau upah dari suatu korporasi yang menerima bantuan dari keuangan negara atau daerah;

5) orang yang menerima gaji atau upah dari korporasi lain yang mempergunakan modal atau fasilitas dari negara atau masyarakat.

c. Setiap orang adalah orang perseorangan atau termasuk korporasi.

Di samping itu diatur pula unsur-unsur tindak pidana korupsi di dalam UU Tipikor dan Revisi UU Tipikor. Rumusan unsur-unsur tindak pidana korupsi mempunyai maksud untuk memberikan gambaran tentang jenis-jenis tindak pidana korupsi dalam dua undang-undang a quo, cukup jelas dalam upaya pencegahan dan pemberantasan korupsi. Jika ditelaah secara cermat substansi UU a quo telah menjangkau berbagai jenis perbuatan yang telah dijadikan sebagai tindak pidana korupsi.

4. Undang-Undang Nomor 7 Tahun 2017 tentang Rencana Pembangunan Jangka Panjang 2005-2025.

Politik hukum pemerintah dalam pemberantasan korupsi dapat pula dilihat dalam Undang-Undang Nomor 7 Tahun 2017 tentang Rencana Pembangunan Jangka Panjang 2005-2025. Rencana Pembangunan Jangka Panjang Nasional Tahun 2005 - 2025 yang selanjutnya disebut sebagai RPJP 
Nasional adalah dokumen perencanaan pembangunan nasional untuk periode 20 (dua puluh) tahun terhitung sejak tahun 2005 sampai dengan tahun 2025.41

RPJP Nasional merupakan penjabaran dari tujuan dibentuknya Pemerintahan Negara Indonesia yang tercantum dalam Pembukaan Undang-Undang Dasar Negara Republik Indonesia Tahun 1945, yaitu untuk melindungi segenap bangsa dan seluruh tumpah darah Indonesia, memajukan kesejahteraan umum, mencerdaskan kehidupan bangsa, dan ikut melaksanakan ketertiban dunia yang berdasarkan kemerdekaan, perdamaian abadi, dan keadilan sosial dalam bentuk rumusan visi, misi dan arah Pembangunan Nasional. ${ }^{42}$ Untuk memastikan roadmap RPJP dapat dilihat dalam Lampiran yang merupakan satu kesatuan dan bagian yang tidak terpisahkan dalam Undang-Undang Nomor 7 Tahun 2017 tentang Rencana Pembangunan Jangka Panjang 2005-2025.43

Berdasarkan Lampiran Undang-Undang Nomor 7 Tahun 2017 tentang Rencana Pembangunan Jangka Panjang 2005-2025 telah dikonstruksikan politik hukum pemberantasan korupsi merupakan bagian dari pembangunan hukum. Pembangunan hukum juga diarahkan untuk menghilangkan kemungkinan terjadinya tindak pidana korupsi serta mampu menangani dan menyelesaikan secara tuntas permasalahan yang terkait kohrsi, korupsi, nepotisme (KKN). ${ }^{44}$

$41 \quad$ Pasal 1 angka 1 Undang-Undang Nomor 7 Tahun 2017 tentang Rencana Pembangunan Jangka Panjang 2005-2025.

42 Pasal 3 Undang-Undang Nomor 7 Tahun 2017 tentang Rencana Pembangunan Jangka Panjang 2005-2025.

$43 \quad$ Pasal 4 ayat (1) Undang-Undang Nomor 7 Tahun 2017 tentang Rencana Pembangunan Jangka Panjang 2005-2025.

44 Lampiran Undang-Undang Nomor 7 Tahun 2017 tentang Rencana Pembangunan Jangka Panjang 2005-2025. 


\section{Undang-Undang Nomor 30 Tahun 2002 tentang Komisi}

Pemberantasan Tindak Pidana Korupsi dan Undang-Undang Nomor 19 Tahun 2019 tentang Perubahan Kedua Undang-Undang Nomor 30 Tahun 2002 tentang Komisi Pemberantasan Tindak Pidana Korupsi

Dewasa ini korupsi masih tetap saja eksis bahkan menyeruak di berbagai sektor, sehingga wajar tindak pidana korupsi disebut dengan extra ordinary crime. Untuk mengatasi hal tersebut maka harus ditanggapi dengan extra ordinary action. ${ }^{45}$ Perlu diketahui ihwal KPK lahir dari rasa kegundahan publik dan ketidakpuasaan terhadap lembaga konvensional. KPK merupakan kebutuhan praktik bernegara yang terus bergerak mengikuti dinamika kompeksitas persoalan menghendaki hadirnya institusi baru. Karena pembagian kekuasaan negara secara konvensional yang mengasumsikan hanya ada tiga cabang kekuasaan di suatu negara tak lagi mampu menjawab kompleksitas yang muncul dalam perkembangan negara modern. ${ }^{46}$

Pada awal kehadirannya KPK didesain sebagai lembaga negara yang dalam melaksanakan tugas dan wewenangnya bersifat independen dan bebas dari pengaruh

45 Disarikan dari Firman Jaya Daeli (Fraksi Partai Demokrasi Indonesia Perjuangan) pada rapat Panja RUU Komisi Pemberantasan Korupsi (RUU KPK), tanggal 5 Desember 2001.

46 Disarikan dari pendapat Saldi Isra dalam kata pengantar buku Zainal Arifin Mochtar, Lembaga Negara Independen: Dinamika Perkembangan dan Urgensi Penataan Kembali Pasca-Amandemen Konstitusi, (Jakarta: Rajawali Pers, 2017), hlm. 82. Lihat bagian Menimbang huruf b Undang-Undang Nomor 30 Tahun 2002 tentang Komisi Pemberantasan Tindak Pidana Korupsi, disebutkan bahwa lembaga pemerintah yang menangani perkara tindak pidana korupsi belum berfungsi secara efektif dan efisien dalam memberantas tindak pidana korupsi. Lihat menimbang huruf c bahwa sesuai dengan ketentuan Pasal 43 Undang-Undang Nomor 31 Tahun 1999 tentang Pemberantasan Tindak Pidana Korupsi sebagaimana telah diubah dengan Undang-Undang Nomor 20 Tahun 2001 tentang Perubahan atas Undang-Undang Nomor 31 Tahun 1999 tentang Pemberantasan Tindak Pidana Korupsi, perlu dibentuk Komisi Pemberantasan Tindak Pidana Korupsi yang independen dengan tugas dan wewenang melakukan pemberantasan tindak pidana korupsi. 
kekuasaan manapun. ${ }^{47}$ Dalam menjalankan tugas dan wewenangnya KPK berasaskan: a. kepastian hukum; $b$. keterbukaan; c. akuntabilitas; d. kepentingan umum dan e. proporsionalitas. ${ }^{48}$

KPK dibentuk dengan tujuan meningkatkan daya guna dan hasil guna terhadap upaya pemberantasan tindak pidana korupsi. Untuk meningkatkan dayaguna dan hasil guna terhadap upaya pemberantasan tindak pidana korupsi, KPK mempunyai tugas sebagai berikut: ${ }^{49}$

a. koordinasi dengan instansi yang berwenang melakukan pemberantasan tindak pidana korupsi;

b. supervisi terhadap instansi yang berwenang melakukan pemberantasan tindak pidana korupsi;

c. melakukan penyelidikan, penyidikan, dan penuntutan terhadap tindak pidana korupsi;

d. melakukan tindak-tindak pencegahan tindak pidana korupsi; dan

e. melakukan monitor terhadap penyelenggara pemerintahan negara.

Susunan organisasi KPK dalam UU KPK terdiri sebagai berikut: a. Pimpinan komisi Pemberantasan Korupsi yang terdiri dari 5 (lima) Anggota Komisi Pemberantasan korupsi; b. Tim Penasihat yang terdiri dari 4 (empat) Anggota; dan c. Pegawai Komisi Pemberantasan Korupsi sebagai pelaksana tugas. ${ }^{50}$

Pimpinan KPK terdiri dari Ketua Komisi Pemberantasan Korupsi merangkap Anggota dan Wakil Ketua Komisi Pemberantasan Korupsi terdiri atas 4 (empat)

47 Lihat Pasal 3 Undang-undang Nomor 30 Tahun 2002 tentang Komisi Pemberantasan Tindak Pidana Korupsi.

48 Pasal 5 Undang-undang Nomor 30 Tahun 2002 tentang Komisi Pemberantasan Tindak Pidana Korupsi.

49 Pasal 6 Undang-undang Nomor 30 Tahun 2002 tentang Komisi Pemberantasan Tindak Pidana Korupsi.

$50 \quad$ Pasal 21 ayat (1) Undang-undang Nomor 30 Tahun 2002 tentang Komisi Pemberantasan Tindak Pidana Korupsi. 
orang, masing-masing merangkap Anggota. 51 Status Pimpinan KPK adalah sebagai pejabat negara. ${ }^{52}$ Selain itu Pimpinan KPK juga merupakan penyidik dan penuntut umum. ${ }^{53}$

Tim Penasihat diangkat oleh KPK setelah melalui proses seleksi pemilihan. ${ }^{54}$ Tim Penasihat terdiri dari 4 (empat) orang anggota. ${ }^{55}$ Dalam hal ini Tim Penasihat berfungsi memberikan nasihat dan pertimbangan sesuai dengan kepakarannya kepada Komisi Pemberantasan Korupsi dalam pelaksanaan tugas dan wewenang Komisi Pemberantasan Korupsi. 56 Selain itu dalam susunan organisasi KPK ada unsur Pegawai. Dalam hal ini Pegawai KPK adalah warga negara Indonesia yang karena keahliannya diangkat sebagai pegawai pada KPK. 57

Pasca terbitnya Revisi UU KPK, desain kelembagaan KPK dalam sistem ketatanegaraan mengalami perubahan di mana sebelumnya KPK bersifat independen dan bebas dari pengaruh kekuasaan manapun, kini KPK menjadi lembaga negara dalam rumpun kekuasaan eksekutif. 58 Yang dimaksud dengan "lembaga negara" adalah negara negara yang bersifat sebagai state auxiliary agency yang masuk

51 Pasal 22 Undang-undang Nomor 30 Tahun 2002 tentang Komisi Pemberantasan Tindak Pidana Korupsi.

52 Pasal 21ayat (4) Undang-undang Nomor 30 Tahun 2002 tentang Komisi Pemberantasan Tindak Pidana Korupsi.

53 Pasal 21 ayat (5) Undang-undang Nomor 30 Tahun 2002 tentang Komisi Pemberantasan Tindak Pidana Korupsi.

54 Pasal 22 ayat (1) Undang-undang Nomor 30 Tahun 2002 tentang Komisi Pemberantasan Tindak Pidana Korupsi.

55 Pasal 22 ayat (5) Undang-undang Nomor 30 Tahun 2002 tentang Komisi Pemberantasan Tindak Pidana Korupsi.

56 Pasal 23 Undang-undang Nomor 30 Tahun 2002 tentang Komisi Pemberantasan Tindak Pidana Korupsi

57 Pasal 24 ayat (2) Undang-undang Nomor 30 Tahun 2002 tentang Komisi Pemberantasan Tindak Pidana Korupsi

58 Pasal 3 Undang-Undang Nomor 19 Tahun 2019 tentang Perubahan Kedua Atas Undang-undang Nomor 30 Tahun 2002 tentang Komisi Pemberantasan Tindak Pidana Korupsi, disebutkan bahwa Komisi Pemberantasan Korupsi adalah lembaga negara dalam rumpun kekuasaan eksekutif yang dalam melaksanakan tugas dan wewenangnya bersifat independen dan bebas dari pengaruh kekuasaan manapun. 
dalam rumpun eksekutif. Dalam ketentuan ini yang dimaksud dengan "kekuasaan manapun" adalah kekuatan yang dapat mempengaruhi tugas dan wewenang Komisi Pemberantasan Korupsi atau anggota Komisi secara individual dari pihak eksekutif, yudikatif, legislatif, pihak-pihak lain yang terkait dengan perkara tindak pidana korupsi, atau keadaan dan situasi ataupun dengan alasan apapun 59

Berdasarkan kedua pengaturan a quo terlihat jelas pergeseran format kelembagaan KPK yang independen terbebas dari pengaruh manapun menjadi KPK yang masuk dalam lingkup eksekutif. Hal tersebut rasanya kontradiktif bahkan terkesan menegasikan makna independen. Di satu sisi, KPK dalam menjalankan tugas dan wewenang yang dimilikinya kini tetap bersifat independen dan bebas dari pengaruh kekuasaan manapun, di sisi lain KPK secara kelembagaan masuk dalam rumpun eksekutif. Apakah mungkin KPK bisa bekerja secara efektif seperti dahulu jika KPK terkungkung dalam kekuasaan eksekutif. ${ }^{60}$

Zainal Arifin Mochtar menyebutkan salah satu karakteristik lembaga yang lahir dan ditempatkan tidak menjadi bagian dari cabang kekuasaan yang ada meskipun pada saat yang sama ia menjadi lembaga negara independen yang mengerjakan tugas yang dulunya dipegang oleh pemerintah. ${ }^{61}$ Dengan demikian meletakkan lembaga antikorupsi pada salah satu cabang kekuasaan cenderung menyebabkan lembaga antikorupsi menjadi tidak independen, sehingga lebih jauh berdampak pada tidak profesionalnya kerja lembaga pemberantas korupsi tersebut. Jika tidak independen, intervensi mudah dilakukan, benturan kepentingan akan menjadi penghambat utama

59 Penjelasan Pasal 3 Undang-Undang Nomor 19 Tahun 2019 tentang Perubahan Kedua Atas Undang-undang Nomor 30 Tahun 2002 tentang Komisi Pemberantasan Tindak Pidana Korupsi.

60 Adam Setiawan dan Nehru Asyikin "Kedudukan KPK dalam Sistem Ketatanegaraan Pasca Diterbitkannya Revisi Undang-Undang KPK", Justitia Jurnal Hukum, Volume 04, Nomor 01, April 2020, hlm. 138.

61 Zainal Arifin Mochtar, op.cit, hlm. 64. 
kerja lembaga antikorupsi. ${ }^{62} \mathrm{Hal}$ selaras dikemukakan oleh John Quah di mana komisi antikorupsi dalam melaksanakan tugas hariannya harus terbebas dari pengaruh para pemimpin politik. Karena, komisi antikorupsi harus dapat melakukan proses hukum yang benar kepada siapapun, tanpa terkecuali, termasuk pada para pemimpin politik dan pejabat senior pemerintahan, tanpa merasa terancam atau takut sedikitpun. ${ }^{63}$

Dalam menjalankan tugas dan wewenangnya, KPK berasaskan pada: a. kepastian hukum; b. keterbukaan; c. akuntabilitas; $\mathrm{d}$. kepentingan umum; proporsionalitas; dan $\mathrm{f}$. Penghormatan terhadap hak asasi manusia. Berdasarkan UU a quo KPK mempunyai tugas antara lain: ${ }^{64}$

a. tindakan-tindakan pencegahan sehingga tidak terjadi Tindak Pidana Korupsi;

b. koordinasi dengan instansi yang berwenang melaksanakan Pemberantasan Tindak Pidana Korupsi dan instansi yang bertugas melaksanakan pelayanan publik;

c. monitor terhadap penyelenggaraan pemerintahan negara;

d. supervisi terhadap instansi yang berwenang melaksanakan Pemberantasan Tindak Pidana Korupsi;

e. penyelidikan, penyidikan, dan penuntutan terhadap Tindak Pidana Korupsi; dan

f. tindakan untuk melaksanakan penetapan hakim dan putusan pengadilan yang telah memperoleh kekuatan hukum tetap.

Sementara itu pasca terbitnya Revisi UU a quo, berimplikasi pula pada susunan organisasi KPK, dimana awalnya KPK terdiri dari unsur Pimpinan KPK, Tim

62 Denny Indrayana, op.cit., hlm 79.

63 Ibid.

64 Pasal 6 Undang-Undang Nomor 19 Tahun 2019 tentang Perubahan Kedua Atas Undang-undang Nomor 30 Tahun 2002 tentang Komisi Pemberantasan Tindak Pidana Korupsi. 
Penasihat dan Pegawai KPK, kini KPK terdiri dari unsur Dewan Pengawas yang berjumlah 5 (lima) orang, Pimpinan KPK yang bterdiri dari 5 (lima) orang Anggota, dan Pegawai KPK. 65

Adapun perubahan unsur KPK dari Tim Penasihat menjadi Dewan Pengawas, dalam hal ini telah menimbulkan diskursus baru, karena mengingat perbedaan tupoksi yang dimiliki Tim Penasihat dan Dewan Pengawas. Berdasarkan Revisi UU KPK, Dewan Pengawas mempunyai tugas sebagai berikut: ${ }^{6}$

a. mengawasi pelaksanaan tugas dan wewenang Komisi Pemberantasan Korupsi;

b. memberikan izin atau tidak memberikan izin Penyadapan, penggeledahan, dan/atau penyitaan;

c.menyusun dan menetapkan kode etik Pimpinan dan Pegawai Komisi Pemberantasan Korupsi;

d. menerima tindak lanjut laporan masyarakat mengenai adanya dugaan pelanggaran kode etik oleh Pimpinan dan Pegawai Komisi Pemberantasan Korupsi atau pelanggaran ketentuan dalam Undang-Undang ini;

e. menyelenggarakan sidang untuk memeriksa adanya dugaan pelanggaran kode etik oleh Pimpinan dan Pegawai Komisi Pemberantasan Korupsi; dan

f. melakukan evaluasi kinerja Pimpinan dan Pegawai Komisi Pemberantasan Korupsi secara berkala 1 (satu) kali dalam 1 (satu) tahun.

Merujuk pada konstruksi pasal a quo, dalam hal ini telah membatasi ruang gerak KPK dalam upaya pemberantasan korupsi, mengingat kewenangan Dewan Pengawas yang relatif sangat besar tentunya

65 Pasal 21 Undang-Undang Nomor 19 Tahun 2019 tentang Perubahan Kedua Atas Undang-undang Nomor 30 Tahun 2002 tentang Komisi Pemberantasan Tindak Pidana Korupsi.

66 Pasal 37B ayat (1) Undang-Undang Nomor 19 Tahun 2019 tentang Perubahan Kedua Atas Undang-undang Nomor 30 Tahun 2002 tentang Komisi Pemberantasan Tindak Pidana Korupsi. 
kontraproduktif dengan semangat pemberantasan korupsi hingga ke akar-akarnya. Dewan Pengawas yang seyogianya hanya mempunyai tugas mengontrol kinerja Pimpinan dan anggota KPK malah diberikan kewenangan lebih dalam hal memberikan izin atau tidak memberikan izin penyadapan, penggeledahan, dan/atau penyitaan yang masuk dalam kategori pro justitia.

Argumentasi Denny Indrayana semakin menguatkan bahwa pemberian izin kepada Dewan Pengawas, yang anggotanya semua dipilih Presiden, cenderung melanggar prinsip independensi KPK yang dalam Pasal 3 UU KPK dirumuskan, "Komisi Pemberantasan Korupsi adalah lembaga negara yang dalam melaksanakan tugas dan wewenangnya bersifat independen dan bebas dari pengaruh kekuasaan manapun". Nah, kewenangan penyadapan KPK yang harus seizin Dewan Pengawas, berpontensi melanggar tugas dan wewenang KPK "yang bersifat independen dan bebas dari pengaruh manapun". ${ }^{67}$ Oleh karena itu dengan kewenangan Dewan Pengawas yang begitu besar, Dewan Pengawas akan berpotensi menjadi kanal bagi pemangku kekuasaan khususnya ranah kekuasaan eksekutif untuk mengintervensi upaya pemberantasan korupsi yang dilakukan oleh KPK.

Selain itu disebutkan pula dalam Revisi UU a quo bahwa Pegawai KPK adalah Aparatur Sipil Negara sebagaimana dimaksud dalam peraturan perundang-undangan mengenai Aparatur Sipil Negara. ${ }^{68}$ Lebih lanjut disebutkan bahwa Pegawai KPK

67 Indriyanto Seno Aji, et.al, Pengujian Oleh Publik (Public Review) Terhadap Rancangan Undang-Undang Tentang Komisi Pemberantasan Tindak Pidana Korupsi, (Jakarta: ICW, 2016), hlm. 143.

68 Pasal 1 angka 6 Undang-Undang Nomor 19 Tahun 2019 tentang Perubahan Kedua Atas Undang-undang Nomor 30 Tahun 2002 tentang Komisi Pemberantasan Tindak Pidana Korupsi. 
merupakan anggota korps pegawai Aparatur Sipil Negara Republik Indonesia. ${ }^{69}$

Berdasarkan konstruksi Pasal yang menyebutkan bahwa Pegawai KPK merupakan Aparatur Sipil Negara (selanjutnya disebut ASN), maka proses pengangkatan Pegawai KPK bukan lagi merupakan kewenangan KPK melainkan kewenangan Kementerian Pendayagunaan Aparatur Negara dan Reformasi Birokrasi (MENPAN-RB) dan Badan Kepegawaian Negara (BKN). ${ }^{70} \mathrm{Di}$ samping itu perubahan status Pegawai KPK menjadi ASN berpotensi menimbulkan conflict of interst, tatkala pegawai KPK yang berstatus ASN menjalankan tugasnya dalam pemberantasan korupsi harus berhadapan dengan atasannya, atau sesama korps ASN yang terlibat kasus korupsi sehingga nantinya akan berpengaruh pada objektifitas upaya pemberantasan korupsi yang dilakukan.

Teori Contract Suigeneris yang dikemukakan oleh Buys menguatkan argumentasi bahwa Pegawai KPK yang berstatus ASN akan berpotensi menimbulkan conflict of insterst, karena dalam teori tersebut disyaratkan pegawai negeri harus setia dan taat selama menjadi Pegawai Negeri, meskipun dia setiap saat mengundurkan diri. ${ }^{71}$ Dengan kata lain Pegawai KPK yang berstatus ASN harus setia dan taat pada korpsnya, jika tidak yang bersangkutan akan dipinggirkan atau diberhentikan.

Berdasarkan kedua pengaturan a quo terlihat perbedaan yang sangat signifikan terkait KPK, baik itu dari segi format kelembagaan KPK, unsur-unsur KPK maupun tugas KPK. Hal demikian tentunya akan berimplikasi pada ikhtiar pemberantasan korupsi yang selama ini telah dilakukan, mengingat kinerja KPK (sebelum Revisi UU

69 Pasal 24 ayat (2) Undang-Undang Nomor 19 Tahun 2019 tentang Perubahan Kedua Atas Undang-undang Nomor 30 Tahun 2002 tentang Komisi Pemberantasan Tindak Pidana Korupsi.

70 Lihat Pasal 25 ayat (2) Undang-Undang Nomor 5 Tahun 2014 tentang Aparatur Sipil Negara.

71 Lihat Ridwan HR dan Nurmalita Ayuningtyas Harahap, Hukum Kepegawaian, (Yogyakarta: UII Press, 2018), hlm 23. 
KPK) terbukti efektif menangkap para koruptor melalui OTT dll. Dengan adanya perubahan UU KPK tidak menutup kemungkinan upaya pemberantasan korupsi akan mengalami stagnansi, seperti praktiknya saat ini beberapa tersangka masih menjadi DPO (Daftar Pencarian Orang) sebut saja Harun Masiku yang terlibat dalam kasus penyuapan Wahyu Setiawan mantan komisioner Komisi Pemilihan Umum.

\section{Peraturan Presiden Nomor 54 Tahun 2018 tentang Strategi Nasional Pencegahan Korupsi.}

Politik Hukum Pemberantasan Korupsi tidak hanya termaktub pada tingkatan Tap MPR dan Undang-undang, tetapi diatur pula dalam tingkatan Peraturan Presiden, dalam hal ini Peraturan Presiden Nomor 54 Tahun 2018 tentang Strategi Nasional Pencegahan Korupsi (selanjutnya disebut Perpres Stranas PK). Terbitnya Perpres Stranas PK menggantikan Peraturan Presiden Nomor 55 Tahun 2012 tentang Strategis Nasional Pencegahan dan Pemberantasan Korupsi Jangka Panjang Tahun 2012-2025 dan Jangka Menengah Tahun $2012-2014 .^{72}$

Pencegahan korupsi perlu dilakukan secara lebih optimal sehingga dibutuhkan upaya yang dilaksanakan bersama dan bersinergi oleh kementerian, lembaga, pemerintah daerah, pemangku kepentingan lainnya, dan Komisi Pemberantasan Korupsi dalam rangka mewujudkan masyarakat yang adil, makmur dan sejahtera. ${ }^{73}$ Dalam rangka mewujudkan upaya pencegahan korupsi diperlukan

72 Lihat Menimbang huruf c Peraturan Presiden Nomor 54 Tahun 2018 tentang Strategi Nasional Pencegahan Korupsi, disebutkan bahwa Peraturan Presiden Nomor 55 Tahun 2012 tentang Strategi Nasional Pencegahan dan Pemberantasan Korupsi Jangka Panjang Tahun 2012-2025 dan Jangka Menengah Tahun 2012-2014 sudah tidak sesuai lagi dengan perkembangan kebutuhan pencegahan korupsi sehingga perlu diganti.

73 Lihat Menimbang huruf b Peraturan Presiden Nomor 54 Tahun 2018 tentang Strategi Nasional Pencegahan Korupsi. 
strategi nasional yang lebih berfokus, terukur, dan berorientasi pada hasil dan dampak. ${ }^{74}$

Stranas PK adalah arah kebijakan nasional yang memuat fokus dan sasaran pencegahan korupsi yang digunakan sebagai acuan kementerian, lembaga, pemerintah daerah dan pemangku kepentingan lainnya dalam melaksanakan aksi pencegahan korupsi di Indonesia. ${ }^{75}$ Fokus Stranas PK meliputi tiga aspek yakni: a. perizinan dan tata niaga; b. keuangan negara; dan c. penegakan hukum dan reformasi birokrasi. ${ }^{76}$

Penyusunan Stranas PK dimaksudkan untuk mendorong upaya pencegahan korupsi yang lebih efektif dan efisien. Upaya pencegahan korupsi menjadi lebih efektif apabila terfokus pada sektor yang mempengaruhi performa pembangunan dan kepercayaan publik kepada Pemerintah. Pencegahan korupsi akan semakin efisien, apabila beban administrasi dan tumpang tindih dapat dikurangi secara signifikan melalui kolaborasi yang lebih baik antara kementerian, lembaga, pemerintah daerah, pemangku kepentingan lainnya, dan Komisi Pemberantasan Korupsi. ${ }^{77}$ Tujuan dari Stranas PK adalah sebagai berikut: ${ }^{78}$

a. memberikan arahan tentang upaya-upaya strategis yang perlu dilakukan oleh kementerian, lembaga, pemerintah daerah, dan pemangku kepentingan lain untuk mencegah korupsi;

b. mendorong program pencegahan korupsi yang berorientasi pada hasil (outcome) dan dampak (impact) bukan hanya luaran kegiatan (output) dengan capaian yang terukur; dan

74 Lihat Menimbang huruf c Peraturan Presiden Nomor 54 Tahun 2018 tentang Strategi Nasional Pencegahan Korupsi.

75 Pasal 1 angka 1 Peraturan Presiden Nomor 54 Tahun 2018 tentang Strategi Nasional Pencegahan Korupsi.

76 Pasal 3 ayat (1) Peraturan Presiden Nomor 54 Tahun 2018 tentang Strategi Nasional Pencegahan Korupsi.

77 Lampiran Peraturan Presiden Nomor 54 Tahun 2018 tentang Strategi Nasional Pencegahan Korupsi

78 Ibid. 
c. meningkatkan sinergi antara program pencegahan korupsi dengan kebijakan pemerintah pusat, pemerintah daerah, pemangku kepentingan maupun dengan kebijakan strategis Komisi Pemberantasan Korupsi.

Adapun Perpres Stranas PK yang dibentuk oleh Pemerintah telah mengakomodir upaya pencegahan secara bersinergi antara kementerian, lembaga pemerintah daerah dan pemangku kepentingan termasuk KPK. Namun yang menjadi kelemahan ada pada tahap implementasi, sebagaimana hasil pelaksanaan aksi pencegahan korupsi pada semester I menunjukkan ada 8 (delapan) Pemprov yang mendapatkan nilai rendah di bawah 50\%. Ke delapan Pemprov yang masih belum patuh pada upaya pencegahan korupsi itu adalah Sumatera Utara $(48 \%)$, Sumatera Barat (0\%), Jawa Tengah (49\%), Kalimantan Tengah (0\%), Kalimantan Barat (0\%), Sulawesi Tengah (0\%), Papua (33\%), dan Papua Papua Barat (42\%). ${ }^{79}$ Dengan demikian perlu adanya evaluasi secara komprehensif mengenai pelaksanaan aksi pencegahan korupsi.

\section{E. Karakter Produk Hukum Pemberantasan Korupsi.}

Untuk menentukan karakter produk hukum pemberantasan korupsi, rasanya perlu dikemukakan secara singkat indikator yang dapat digunakan. Dalam hal ini Penulis meminjam konseptual dan indkator-indikator yang digunakan oleh Mahfud MD, ada 2 (dua) karakter produk hukum yakni produk hukum resposif/populistik dan produk hukum konservatif/ortodoks. ${ }^{80}$

Pertama, produk hukum responsif/populistik adalah produk hukum yang mencerminkan rasa keadilan dan memenuhi harapan masyarakat. Dalam proses pembuatannya

79 Lihat

Berita

Stranas

PK,

https://stranaspk.kpk.go.id/id/berita/delapan-pemprov-dinilai-rendah-capaian-a ksi-pencegahan-korupsi, Lihat pula Laporan Pelaksanaan Strategi Nasional Pencegahan.

80 Moh. Mahfud MD, Politik Hukum..., op.cit, hlm. 32. 
memberikan peranan besar dan partispasi penuh kelompok-kelompok sosial atau individu di dalam masyarakat. Hasilnya bersifat responsif terhadap tuntutan-tuntutan kelompok sosial atau individu dalam masyarakat. Kedua, produk hukum konservatif/ortodoks/elitis adalah produk hukum yang isinya lebih mencerminkan visi sosial elite politik, lebih mencerminkan keinginan pemerintah, bersifat positivis-instrumentalis, yakni menjadi alat pelaksanaan ideologi dan program negara. Berlawanan dengan hukum responsif, hukum ortodoks lebih tertutup terhadap tuntutan-tuntutan kelompok maupun individu-individu di dalam masyarakat. Dalam pembuatannya peranan dan partisipasi masyarakat relatif kecil. ${ }^{81}$

Indikator yang digunakan adalah proses pembuatan hukum, sifat fungsi hukum, dan kemungkinan penafsiran atas sebuah produk hukum. Produk hukum yang berkarakter responsif, proses pembuatannya bersifat partisipatif, yakni mengundang sebanyak-banyaknya partisipasi masyarakat melalui kelompok-kelompok sosial dan individu di dalam masyarakat. Sedangkan proses pembuatan hukum yang berkarakter ortodoks bersifat sentralistik dalam arti lebih didominasi oleh lembaga negara terutama pemegang kekuasaan eksekutif. ${ }^{82}$

Dilihat dari fungsinya maka hukum yang berkarakter responsif bersifat aspiratif. Artinya memuat materi-materi yang secara umum sesuai dengan aspirasi atau kehendak masyarakat yang dilayaninya. Sehingga produk hukum itu dapat dipandang sebagai kristalisasi dan kehendak masyarakat. Sedangkan hukum yang berkarakter ortodoks bersifat positivis-instrumentalis. Artinya memuat materi yang lebih merefleksikan visi sosial dan politik pemegang kekuasaan atau memuat materi yang lebih merupakan alat untuk mewujudkan kehendak dan kepentingan program pemerintah. ${ }^{83}$

$\begin{array}{ll}81 & \text { Ibid. } \\ 82 & \text { Ibid. } \\ { }_{83} & \text { Ibid. }\end{array}$ 
Selanjutnya dari segi penafsiran, produk hukum yang berkarakter responsif/populistik biasanya memberi sedikit peluang bagi pemerintah untuk membuat penafsiran sendiri melalui berbagai peraturan pelaksanaan dan peluang yang sempit itu pun hanya berlaku untuk hal-hal yang betul-betul bersifat teknis. Sedangkan produk hukum yang berkarakter ortodoks/konservatif/elitis memberi peluang luas kepada pemerintah untuk membuat berbagai interpretasi dengan berbagai peraturan lanjutan yang berdasarkan visi sepihak dari pemerintah dan tidak sekedar masalah teknis. Oleh sebab itu, produk hukum yang berkarakter responsif biasanya memuat hal-hal penting secara cukup rinci, sehingga sulit bagi pemerintah untuk membuat penafsiran sendiri. Sedangkan produk hukum yang berkarakter ortodoks biasanya cenderung memuat materi singkat dan pokok-pokoknya saja untuk kemudian memberi peluang yang luas bagi pemerintah untuk mengatur berdasarkan visi dan kekuatan politiknya. ${ }^{84}$

Dewasa ini, pengaturan terkait pemberantasan korupsi sudah cukup komprehensif baik diatur dalam tingkatan Tap MPR maupun Peraturan Daerah. Namun dalam penulisan ini, Penulis hanya memaparkan sebagian peraturan yang dinilai sebagai fondasi awal dalam pemberantasan korupsi.

1. Ketetapan MPR Nomor XI/MPR/1998 Tahun 1998 tentang Penyelenggara Negara yang Bersih dan Bebas Korupsi, Kolusi, dan Nepotisme.

Ketetapan MPR Nomor XI/MPR/1998 Tahun 1998 tentang Penyelenggara Negara yang Bersih dan Bebas Korupsi, Kolusi, dan Nepotisme, dibentuk pada masa transisi dari rezim Orde Baru yang terkenal Otoriter ke era reformasi.

Jika ditelaah secara cermat karakter produk hukum dari Ketetapan MPR Nomor XI/MPR/1998 adalah berkarakter hukum responsif, karena baik secara substansi maupun proses pembentukannya telah mengakomodir segala tuntutan masyarakat yang menginginkan para

84 Ibid. 
penyelenggara negara terbebas dari praktik KKN mengingat praktik KKN yang begitu masif pada rezim Orde Baru. Berdasarkan konsideran Ketetapan MPR Nomor XI/MPR/1998 menyebutkan tuntutan hati nurani rakyat menghendaki adanya penyelenggara negara yang mampu menjalankan fungsi dan tugasnya secara sungguh-sungguh dan penuh tanggung jawab agar reformasi pembangunan dapat berdayaguna dan berhasil guna.

2. Ketetapan MPR Nomor VIII/MPR/2001 Tahun 2001 tentang Rekomendasi Arah Kebijakan Pemberantasan dan Pencegahan Korupsi, Kolusi, dan Nepotisme.

Ketetapan MPR Nomor VIII/MPR/2001 Tahun 2001, merupakan komitmen awal pemerintah kala itu dalam memperkuat upaya pemberantasan korupsi, kolusi dan nepotisme pasca runtuhnya rezim Orde Baru. sejak tahun 1998, masalah pemberantasan dan pencegahan korupsi, kolusi, dan nepotisme telah ditetapkan oleh Majelis Permusyawaratan Rakyat Republik Indonesia sebagai salah satu agenda reformasi, tetapi belum menunjukkan arah perubahan dan hasil sebagaimana diharapkan. terdapat desakan kuat masyarakat yang menginginkan terwujudnya berbagai langkah nyata oleh pemerintah dan lembaga-lembaga tinggi negara lainnya dalam hal pemberantasan dan pencegahan korupsi, kolusi, dan nepotisme

Rekomendasi arah kebijakan ini dimaksudkan untuk mempercepat dan lebih menjamin efektivitas pemberantasan korupsi, kolusi, dan nepotisme sebagaimana dalam Ketetapan Majelis Permusyawaratan Rakyat Republik Indonesia Nomor XI/MPR/1998 tentang Penyelenggara Negara yang Bersih dan Bebas Korupsi, Kolusi, dan Nepotisme, serta berbagai peraturan 
perundang-undangan yang terkait. ${ }^{85}$ Dari uraian tersebut dapat disimpulkan bahwa karakter produk hukum Ketetapan MPR Nomor VIII/MPR/2001 Tahun 2001 adalah hukum responsif karena Ketetapan MPR Nomor VIII/MPR/2001 Tahun 2001 merupakan pengaturan lebih lanjut dari Ketetapan MPR Nomor XI/MPR/1998.

Di samping itu pula mengapa Ketetapan MPR Nomor VIII/MPR/2001 Tahun 2001 masuk dalam kualifikasi karakter produk hukum yang responsif, karena salah satu arah kebijakan pemberantasan KKN memerintahkan untuk "membentuk undang-undang beserta peraturan pelaksanaannya untuk membantu percepatan dan efektivitas pelaksanaan pemberantasan korupsi dan pencegahan korupsi", yang diantaranya undang-undang: 1) KPK; 2) Perlindungan Saksi dan Korban; 3) Kebebasan Mendapatkan Informasi. Dengan kata lain, maksud dari membentuk undang-undang beserta peraturan pelaksanaannya untuk membantu percepatan dan efektivitas pelaksanaan pemberantasan korupsi dan pencegahan korupsi, secara tidak langsung memberikan dampak (impact) terhadap masyarakat berupa jaminan perlindungan mengingat tindak pidana korupsi tidak hanya merugikan keuangan negara, tetapi juga melanggar hak-hak sosial dan ekonomi masyarakat secara luas.

3. Undang-Undang Nomor 31 Tahun 1999 tentang Pemberantasan Tindak Pidana Korupsi dan Undang-Undang Nomor 20 Tahun 2001 tentang Perubahan Atas Undang-Undang No 31 Tahun 1999 tentang Pemberantasan Tindak Pidana Korupsi.

Politik hukum UU Tipikor beserta Revisi UU Tipikor merupakan landasan hukum yang dibentuk oleh Pemrintah

85 Pasal 1 Ketetapan MPR Nomor VIII/MPR/2001 Tahun 2001 tentang Rekomendasi Arah Kebijakan Pemberantasan dan Pencegahan Korupsi, Kolusi, dan Nepotisme. 
(DPR dan Presiden) dalam upaya mencegah dan memberantas tindak pidana korupsi. Karakter produk hukum dari peraturan a quo adalah hukum responsif. Alasannya adalah peraturan a quo dibentuk sebagai salah satu instrumen hukum yang dikehendaki oleh seluruh masyarakat agar segala tindak pidana korupsi segera diberantas, mengingat korupsi sangat merugikan keuangan negara, menghambat pertumbuhan dan kelangsungan pembangunan nasional yang menuntut efisiensi tinggi. Bahkan tindak pidana yang selama ini terjadi secara meluas, tidak hanya merugikan keuangan negara, tetapi juga telah merupakan pelanggarang terhadap hak-hak sosial dan ekonomi masyarakat secara luas, sehingga tindak pidana korupsi perlu digolongkan sebagai kejahatan yang pemberantasannya harus dilakukan secara luar biasa.

4. Undang-Undang Nomor 7 Tahun 2017 tentang Rencana Pembangunan Jangka Panjang 2005-2025.

Politik hukum pemberantasan korupsi dapat dilihat dalam Undang-Undang Nomor 7 Tahun 2017 tentang Rencana Pembangunan Jangka Panjang 2005-2025. Berdasarkan Lampiran undang-undang a quo, disebutkan secara eksplisit pembangunan hukum diarahkan untuk menghilangkan kemungkinan terjadinya tindak pidana korupsi serta mampu menangani dan menyelesaikan secara tuntas permasalahan terkait kolusi, korupsi, nepotisme (KKN). Karakter produk hukum Undang-Undang Nomor 7 Tahun 2017, adalah hukum responsif. Alasannya dapat ditinjau dari segi fungsinya hukum yang berkarakter responsif bersifat aspiratif. Artinya memuat materi-materi yang secara umum sesuai dengan aspirasi atau kehendak masyarakat yang dilayaninya. Dengan menyelipkan upaya pencegahan dan pemberantasan korupsi maka dalam hal ini telah mengakomodir tuntutan masyarakat agar upaya pencegahan dan pemberantasan korupsi dalam rencana pembangunan nasional. 
5. Undang-Undang Nomor 30 Tahun 2002 tentang Komisi Pemberantasan Tindak Pidana Korupsi dan Undang-Undang Nomor 19 Tahun 2019 tentang Perubahan Kedua Undang-Undang Nomor 30 Tahun 2002 tentang Komisi Pemberantasan Tindak Pidana Korupsi.

Politik hukum pemerintah dalam pemberantasan korupsi dapat ditinjau dari Undang-Undang Nomor 30 Tahun 2002 tentang Komisi Pemberantasan Tindak Pidana Korupsi dan Undang-Undang Nomor 19 Tahun 2019 tentang Perubahan Kedua Undang-Undang Nomor 30 Tahun 2002 tentang Komisi Pemberantasan Tindak Pidana Korupsi. Dalam hal ini kedua pengaturan a quo mempunyai karakter produk hukum yang berbeda. Hal demikian dapat dilihat dari segi fungsi dan segi penafsiran.

UU KPK mempunyai karakter produk hukum responsif. Jika dianalisis secara cermat, substansi UU KPK dipandang sebagai kristalisasi kehendak rakyat, karena kehadiran KPK merupakan trigger mechanism dari institusi penegak hukum yang dinilai lemah oleh publik dalam hal pemberantasan korupsi. Publik menilai kehadiran KPK merupakan solusi yang tepat dalam upaya pemberantasan korupsi mengingat lemahnya kontribusi penegak hukum konvensional. Alasan lainnya karena format kelembagaan KPK yang dalam melaksanakan tugas dan wewenangnya bersifat independen dan bebas dari pengaruh kekuasaan manapun, sehingga meminimalisir terjadinya campur tangan.

Namun pasca terbitnya Revisi UU KPK, format kelembagaan KPK mengalami perubahan secara elementer. KPK didesain sebagai lembaga yang masuk lingkup kekuasaan eksekutif. Selain itu munculnya Dewan Pengawas sebagai unsur KPK dengan kewenangan pro justitia dan perubahan status Pegawai KPK menjadi ASN,telah menimbulkan polemik. Publik menganggap Pemerintah (DPR dan Presiden) telah berhasil mereduksi kewenangan KPK. Berbagai penolakan pun 
tak terhindarkan, hampir di beberapa daerah termasuk Yogyakarta, dengan seruan "Gejayan Memanggil" aksi damai Mahasiswa dari berbagai kampus, yang pada intinya menolak terbitnya Revisi UU KPK. Oleh karena itu tidak heran karakter produk hukum dari Revisi UU KPK adalah ortodoks/konservatif. Dalam hal ini pembentuk produk hukum telah mengabaikan seluruh aspirasi rakyat agar Revisi UU KPK menjadikan KPK semakin kuat bukan malah sebaliknya.

Berdasarkan beberapa pengaturan yang telah disebutkan di atas, dapat ditarik suatu hipotesis bahwa pengaturan yang berkarakter responsif lebih mencerminkan kehendak rakyat. Berbeda halnya dengan Revisi UU KPK yang jika ditinjau dari materi muatannya tidak mencerminkan kehendak rakyat, KPK telah bertransformasi secara elementer tidak sesuai ekspektasi masyarakat, bahkan terkesan Revisi UU KPK hanya memuat kepentingan para pembentuk undang-undang. Sesuai dengan apa yang Zamboni pernah kemukakan

"the content of the law is either completly independent from or
completly dependent upon politics, particularly after growth of
the nation state and the current globalization occuring in law
making processes. As to this first aspect, the content of the law
cannot be viewed as completely independent from politics
because the organizational political form of the nation state is
characterized, in part, by the fact that the law (in particular in
its statutory forms) is a tool available to parliament sand
governments (i.e. the most important political actors) in orders
to effectuate programs within a certain community." 86

\section{F. Penutup}

Politik hukum pemerintah dalam pemberantasan korupsi tertuang dalam peraturan perundang-undangan, namun ada beberapa peraturan yang dijadikan fondasi awal dalam pemberantasan korupsi di era reformasi yaitu: a) Ketetapan MPR Nomor XI/MPR/1998 Tahun 1998 tentang Penyelenggara

86 Mauro Zamboni, Law and Politics: A Dilemma for Contemporary legal Theory, (Verlag Berlin Heidlberg: Spinger, 2008), hlm. 5-6. 
Negara yang Bersih dan Bebas Korupsi, Kolusi, dan Nepotisme;

b) Ketetapan MPR Nomor VIII/MPR/2001 Tahun 2001 tentang Rekomendasi Arah Kebijakan Pemberantasan dan Pencegahan Korupsi, Kolusi, dan Nepotisme; c) Undang-Undang Nomor 31 Tahun 1999 tentang Pemberantasan Tindak Pidana Korupsi dan Undang-Undang Nomor 20 Tahun 2001 tentang Perubahan Atas Undang-Undang No 31 Tahun 1999 tentang Pemberantasan Tindak Pidana Korupsi; d) Undang-Undang Nomor 7 Tahun 2017 tentang Rencana Pembangunan Jangka Panjang 2005-2025; e) Undang-Undang Nomor 30 Tahun 2002 tentang Komisi Pemberantasan Tindak Pidana Korupsi dan Undang-Undang Nomor 19 Tahun 2019 tentang Perubahan Kedua Undang-Undang Nomor 30 Tahun 2002 tentang Komisi Pemberantasan Tindak Pidana Korupsi.

Dari beberapa peraturan tersebut, Undang-Undang Nomor 19 Tahun 2019 tentang Perubahan Kedua Undang-Undang Nomor 30 Tahun 2002 tentang Komisi Pemberantasan Tindak Pidana Korupsi, dalam hal ini dinilai tidak mencerminkan semangat pemberantasan korupsi. Hal demikian dapat dilihat dari beberapa materi muatan undang-undang a quo, seakan antitesis dari peraturan sebelumnya yang dinilai lebih efektif terhadap pemberantasan korupsi. Dimana awalnya format kelembagaan KPK sebagai lembaga independen mengalami transformasi menjadi bagian kekuasaan eksekutif. Kehadiran Dewan Pengawas dalam unsur KPK dan perubahan status Pegawai KPK menjadi Aparatur Sipil Negara tidak mencerminkan semangat pemberantasan korupsi. Oleh sebab itu tidak heran apabila karakter produk hukum Undang-Undang Nomor 19 Tahun 2019 adalah ortodoks/konservatif berbeda dengan beberapa pengaturan pemberantasan korupsi lainnya yang bersifat responsif.

Pasca terbitnya Undang-Undang Nomor 19 Tahun 2019, banyak yang menilai politik hukum dari undang-undang a quo telah mensegregasikan KPK dalam upaya pencegahan dan pemberantasan korupsi. Oleh karena itu perlu adanya evaluasi yang lebih komprehensif tehadap KPK baik secara 
kelembagaan maupun kinerja struktur organisasinya. Dalam hal ini Presiden mempunyai pilihan untuk menerbitkan Peraturan Pemerintah Pengganti Undang-Undang untuk membatalkan Undang-Undang Nomor 19 Tahun 2019 tentang Perubahan Kedua Undang-Undang Nomor 30 Tahun 2002 tentang Komisi Pemberantasan Tindak Pidana Korupsi. Hal tersebut rasanya perlu dilakukan oleh Presiden sebagai bentuk dukungan Pemerintah terhadap ikhtiar pemberantasan korupsi. 


\section{Daftar Pustaka}

Buku.

Aji,Indriyanto Seno et.al, Pengujian Oleh Publik (Public Review) Terhadap Rancangan Undang-Undang Tentang Komisi Pemberantasan Tindak Pidana Korupsi, Jakarta: ICW, 2016.

Indrayana, Denny, Jangan Bunuh KPK: Kajian Hukum Tata Negara Penguatan Komisi Pemberantasan Korupsi, Malang: Intrans Publishing, 2016.

Kusumaatmadja, Mochtar, Konsep-konsep Hukum dalam Pembangunan: Kumpulan Karya Tulis Prof. Dr. Mochtar Kusumaatmadja, S.H., LL.M, Bandung: Alumni, 2002.

Mahfud MD, Moh, Politik Hukum di Indonesia, Jakarta: Rajawali Pers, 2017.

Mertokusumo, Sudikno, Mengenal Hukum: Suatu Pengantar, Yogyakarta: Cahaya Atma Pustaka, 2010.

Mochtar, Zainal Arifin, Lembaga Negara Independen: Dinamika Perkembangan dan Urgensi Penataan Kembali Pasca-Amandemen Konstitusi, Jakarta: Rajawali Pers, 2017.

Rahardjo, Satjipto, Ilmu Hukum, Cetakan VII, Bandung: Citra Aditya Bakti, 2014.

Renggong, Ruslan, Hukum Pidana Khusus: Memahami Delik-delik di Luar KUHP, Jakarta: Kencana, 2016.

Ridwan dan Nurmalita Ayuningtyas Harahap, Hukum Kepegawaian, Yogyakarta: UII Press, 2018.

Wahjono, Padmo Indonesia Negara Berdasarkan Atas Hukum, Jakarta: Ghalia Indonesia, 1986. 
Zamboni, Mauro, Law and Politics: A Dilemma for Contemporary legal Theory, Verlag Berlin Heidlberg: Spinger, 2008

\section{Jurnal/Makalah/Disertasi}

Cerar, Miro, The Relationship Between and Politics, Annual Survey of International \& Comparative Law, Volume 15, Issue 1, 2009.

Fariz, Donal, Pemerintahan Joko Widodo dan Serangan Politik Terhadap KPK, Jurnal Integrasi, Volume. 5, Nomor 2, 2019.

Hakim Garuda Nusantara, Abdul, Politik Hukum Nasional, makalah disampaikan pada Karya Latihan Bantuan Hukum (KALABAHU), diselenggarakan Yayasan LBH Indonesia dan LBH Surabaya, September 1985.

Mahfud MD, Moh, Mengefektifkan Kontrol Hukum Kekuasaan, Jurnal Ius Quia Iustum, Volume. 3, Nomor 6, 1996.

Quah, John S.T, Anti-Corruption Agencies In Four Asian Countries: A Comparative Analysis, International Public Management Review, Volume 8, Issue 2, 2007.

Risnain, Muh, Kesinambungan Politik Hukum Pemberantasan Korupsi “, Jurnal Rechtsvinding, Volume, Nomor 3, 2014.

Setiawan, Adam dan Nehru Asyikin, Kedudukan KPK dalam Sistem Ketatanegaraan Pasca Diterbitkannya Revisi Undang-Undang KPK, Justitia Jurnal Hukum, Volume 04, Nomor 01, April 2020.

Tamher, Samsul, Penyidikan Tindak Pidana Korupsi Di Wilayah Hukum Kejaksaan Tinggi Papua, Disertasi, Program Doktor Ilmu Hukum Universitas Hasanuddin Makassar, 2018. 
Wahjono, Padmo, Menyelisik Proses Terbentuknya Peraturan Perundang-undang, Majalah Forum Keadilan, Nomor 29, April 1991.

\section{Internet}

Setiawan, Adam, "Mengakhiri Polemik Capim KPK", https://news.detik.com/kolom/d-4691642/mengakhiri-pol emik-capim-kpk, (diakses 4 Juni 2020).

Transparency International Indonesia, chrome extension://oemmndcbldboiebfnladdacbdfmadadm/https: //riset.ti.or.id/wpcontent/uploads/2020/01/map-CPI-201 9.pdf, (diakses 4 Juni 2020).

Berita Stranas PK, https://stranaspk.kpk.go.id/id/berita/delapan-pemprov-d inilai-rendah-capaian-aksi-pencegahan-korupsi, Lihat pula Laporan Pelaksanaan Strategi Nasional Pencegahan.

\section{Peraturan Perundang-undangan}

Ketetapan MPR No XI/MPR/1998 Tahun 1998 Tentang Penyelenggara Negara Yang Bersih dan Bebas Korupsi, Kolusi dan Nepotisme.

Ketetapan MPR No. VIII/MPR/RI Tahun 2001 tentang Rekomendasi Arah Kebijakan Pemberantasan dan Pencegahan Korupsi.

Undang-undang Nomor 31 Tahun 1999 Tentang Pemberantasan Tindak Pidana Korupsi.

Undang-Undang Nomor 20 Tahun 2001 tentang Perubahan Atas Undang-Undang No 31 Tahun 1999 tentang Pemberantasan Tindak Pidana Korupsi. 
Undang-undang Nomor 30 Tahun 2002 tentang Komisi Pemberantasan Tindak Pidana Korupsi.

Undang-Undang Nomor 7 Tahun 2017 tentang Rencana Pembangunan Jangka Panjang 2005-2025.

Undang-Undang Nomor 19 Tahun 2019 tentang Perubahan Kedua Atas Undang-undang Nomor 30 Tahun 2002 tentang Komisi Pemberantasan Tindak Pidana Korupsi

Undang-Undang Nomor 5 Tahun 2014 tentang Aparatur Sipil Negara.

Peraturan Presiden Nomor 54 Tahun 2018 tentang Strategi Nasional Pencegahan Korupsi. 
POLITIK HUKUM TERHADAP PENGAKUAN HAK

ASASI WARGA NEGARA INDONESIA DI DALAM

HUKUM ADMINISTRASI NEGARA

\section{Nehru Asyikin \\ Praktisi Lembaga Bantuan Hukum Aksa Bumi \\ Jl. Sidikan No. 62 RT. 034/RW. 009, Sorosutan, Umbulharjo, \\ Yogyakarta, 55162. \\ Email : nehruasyikin1@gmail.com}

\section{A. Pendahuluan}

Suatu keberuntungan bagi warga negara dalam suatu negara apabila pemerintahannya memberikan perlindungan hak-hak asasi di dalam setiap kegiatan administrasi pemerintahan. Namun itu saja tidak cukup untuk memenuhi hak-hak asasi warga negaranya apabila dalam pelaksanaan pemenuhan hak-hak tersebut tidak terlaksana. Lebih parahnya pengakuan hak-hak asasi tersebut tidak tercantum di setiap peraturan (regeling) dan kebijakan (beschiking) yang memberi jaminan hak-hak tersebut.

Pada zaman seperti ini, perlindungan hak warga negara melalui hukum menjadi kebutuhan yang tidak dapat dihilangkan, sehingga perlakuan dan persamaan di dalam pemenuhan kepentingannya untuk meningkatkan kesejahteraan ekonomi bagi dirinya dan keluarganya merupakan bagian dari haknya sebagai warga negara di dalam negara hukum seperti di Indonesia.

Menurut ajaran yang umum, salah satu daripada syarat atau negara hukum ialah adanya jaminan atas hak-hak asasi. Jaminan ini harus terbaca atau tertafsir dari konstitusi yang berlaku, apakah ia konstitusi tertulis maupun tidak tertulis, setidaknya-tidaknya termaklumi dari praktik-praktik hukum yang berlaku sehari-hari. sebagai hak, maka hak-hak asasi ini tak lepas dari soal kebebasan dan kewajiban, baik di pihak 
pemegang kekuasaan maupun $3 / 4$ pihak pendukung hak asasi itu sendiri. ${ }^{87}$

Pada dimensi administrasi negara, penyelenggaraan tugas-tugas pemerintahan dan kenegaraan dalam suatu negara hukum itu terdapat aturan-aturan hukum yang tertulis dalam konstitusi atau peraturan-peraturan yang terhimpun dalam hukum tata negara. Meskipun demikian, untuk menyelenggarakan persoalan-persoalan bersifat teknis, Hukum Tata Negara ini tidak sepenuhnya dapat dilakasnakan dengan efektif. Maka kemudian, dibutuhkan hukum lain yang bersifat teknis. Hukum tersebut adalah hukum administrasi negara. ${ }^{88}$

Pada konteks hukum administrasi negara, hukum ini tidak hanya memuat peraturan perundang-undangan sebagai petunjuk dalam menjalankan suatu pemerintahan, tetapi dalam perjalanan pemerintahan tersebut menjadi keharusan untuk dibarengi dengan perlindungan hak-hak asasi dan jaminan hukum. Seperti, tidak membeda-bedakan warna kulit, ras, suku dan agama atau karena faktor kolusi dan nepotisme yang menyebabkan perlakuan penyelenggara pemerintahan membeda-bedakan pelayanan. Apalagi dalam kehidupan bernegara di Indonesia saat ini, pluralisme adalah ciri khas bangsa ini.

Paradoks Hak Asasi Manusia (HAM) ini akan banyak kita temukan di daerah-daerah yang sekarang menikmati otonomi yang luas. Konstelasi politik yang rentan karena ikatan koalisi jangka pendek telah memungkinkan kompromi politik dimanipulasi. Akibatnya, ideologi semakin digantikan oleh politik kepentingan jangka pendek yang sebagian didikte oleh rekayasa opini publik. Disinilah pluralisme sering dipangkas termasuk oleh partai politik yang platformnya pluralisme. Diskriminasi yang kita ingin hapus sekarang berganti dengan tuntutan diutamakannya putra daerah dengan segala nepotisme yang merupakan turunannya. Dalam skala kecil

87 Padmo Wahjono, Masalah Ketatanegaraan Indonesia Dewasa Ini (Jakarta: Ghalia Indonesia, 1984). Hlm. 323.

88 Ridwan HR, Hukum Administrasi Negara (Jakarta: PT Rajagrafindo Persada, 2017). Hlm. 23. 
kesemua praktik diskriminasi ini kita temukan di berbagai perusahaan dan organisasi. Terus terang realitas ini sangat berbahaya. ${ }^{89}$

Realitas penerapan HAM di dalam hukum administrasi negara menjadi sangat penting untuk memberikan perlindungan dan kepastian hukum. Dengan catatan bahwa setiap peraturan perundang-undangan itu memuat di dalam substansinya mengenai hak-hak warga negara secara impisit. Dengan kata lain, untuk melindungi hak-hak asasi warga negara dalam penyelenggaraan roda pemerintahan melalui hukum administrasi tersebut, hukum administrasi negara menjadi bagian dari garis kebijakan resmi tentang hukum yang akan diberlakukan baik dengan perbuatan hukum baru maupun dengan penggantian hukum lama dalam rangka mencapai tujuan negara seperti tercantum di dalam Pembukaan UUD 1945. ${ }^{90}$ Sehingga hak asasi warga negara harus menjadi bagian dari budaya hukum Indonesia dan selanjutnya harus ada prosedur hukum untuk mempertahankan dan melindungi Hak Asasi Manusia itu. ${ }^{91}$ Berdasarkan penjabaran sebelumnya, maka penulis mengangkat permasalahan yang di rumuskan sebagai berikut, bagaimana implementasi Politik Hukum Hak Asasi Warga Negara Indonesia dalam hukum administrasi negara dan bagaimana Hukum Administrasi Negara melindungi Hak asasi warga negara?

89 Todung Mulya Lubis, “Menegakkan Hak Asasi Manusia, Menggugat Dlskriminasi," Jurnal Hukum \& $\quad$ Pembangunan 39, no. 1 (2009): 58, https://doi.org/10.21143/jhp.vol39.no1.204. Hlm. 67-68.

90 Moh. Mahfud MD, Politik Hukum Di Indonesia (Jakarta: PT Raja Grafindo Persada, 2017). Hlm. 1.

91 Antonius Sujata, Reformasi Dalam Penegakan Hukum (Jakarta: Djambatan, 2000). Hlm. 32. 


\section{B. Politik Hukum Hak Asasi Warga Negara Indonesia dalam Hukum Administrasi Negara}

\section{Hubungan Hak Asasi Warga Negara Indonesia Menurut UUD 1945 dengan Hukum Administrasi Negara}

Menurut UUD 1945 hanya berbicara tentang "HAW" atau hak asasi warga negara (atau HAM yang partikularistik). Antara keduanya, HAM dan HAW jelas berbeda. Yang pertama mendasar kan diri pada paham bahwa secara kodrati manusia itu, di mana pun, mempunya hak-hak bawaan yang tidak bisa dipindahkan, diambil, atau dialihkan. Adapun yang terakhir, hanya mungkin diperoleh karena seseorang memliki status sebagai wara negara. ${ }^{92}$

Kaitan HAM dengan hukum sangat erat, karena sekalipun HAM merupakan hak negatif (negative rights) karena sifatnya yang kodrati dan universal sehingga tidak memerlukan pengesajan, namun dalam kehdiupan bermasyarakat, bangsa dan bernegara yang semakin kompleks, pengaturan hukum terhadap HAM (positivization of rights) akan memperkuat posisi Indonesia sebagai negara hukum. 93

Untuk melindungi kepentingan manusia di dalam masyarakat terdapat beberapa kaidah sosial. Semula beberapa kaedah tersebut tidak dibedakan. Baru setelah melalui proses yang lama manusia membedakan kaedah-kaedah tersebut. Tata kaedah tersebut terdiri dari kaedah kepercayaan atau keagamaan, kaedah kesusilaan, kaedah sopan santun dan kaedah hukum. ${ }^{94}$

Kewajiban menghormati hak asasi manusia tercermin dalam Pembukaan UUD 1945 yang menjiwai keseluruhan pasal dalam batang tubuhnya, terutama berkaitan dengan persamaan kedudukan warga negara dalam hukum dan

92 Majda El-Muhtaj, Hak Asasi Manusia Dalam Konstitusi Indonesia Dari UUD1945 Sampai Dengan Amandemen UUD 1945 Tahun 2002 (Jakarta: Kencana, 2005). Hlm. 95.

93 Bagir Manan, Kedaulatan Rakyat Hak Asasi Manusia Dan Negara Hukum (Jakarta: Radar Jaya, 1996). Hlm. 117.

94 Sudikno Mertokusumo, Mengenal Hukum Suatu Pengantar (Yogyakarta: Liberty, 1999). Hlm. 5. 
pemerintahan, hak atas pekerjaan dan penghidupan yang layak, kemerdekaan berserikat dan berkumpul, hak untuk mengeluarkan pikiran dengan lisan dan tulisan, kebebasan memeluk agama dan untuk beribadah sesuai dengan agama dan kepercayaannya itu, hak untuk memperoleh pendidikan dan pengajaran. ${ }^{95}$

Melaksanakan kewajiban yang diatur dalam UUD 1945 tersebut, MPR dengan Ketetapan MPR Nomor XVII/MPR/1998 tentang Hak Asasi Manusia, menugaskan kepada lembaga-lembaga tinggi negara dan seluruh aparatur pemerintah untuk menghormati, menegakkan, dan menyebarluaskan pemahaman mengenai hak asasi manusia kepada seluruh masyarakat, serta segera meratifikasi berbagai instrumen Perserikatan Bangsa Bangsa tentang Hak Asasi Manusia, sepanjang tidak bertentangan dengan Pancasila dan UUD 1945. 96

Adapaun hak-hak warga negara Indonesia dijamin dengan konstitusi, yaitu di dalam batang tubuh UUD Negara Republik Indonesia berbunyi sebagai berikut:

a. Pasal 28A, hak untuk hidup serta hak mempertahankan hidup dan kehidupannya;

b. Pasal 28B, hak berkeluarga dan melanjutkan keturunan dari perkawinan yang sah serta hak anak atas kelangsungan hidup, tumbuh, dan berkembang serta berhak atas perlindungan dari kekerasan dan diskriminasi;

c. Pasal 28C, hak mengembangkan diri melalui pemenuhan kebutuhan dasarnya, berhak mendapat pendidikan dan memperoleh manfaat dari ilmu pengetahuan dan teknologi, seni dan budaya, demi meningkatkan kualitas hidupnya dan demi kesejahteraan umat manusia serta hak untuk memajukan dirinya dalam memperjuangkan

95 Muhamad Rakhmat, "Hukum Administrasi Negara Indonesia,", http://www.jurnal.unma.ac.id/index.php/RBJ/article/viewFile/531/495. Akses 8 Juni 2020.

$96 \quad$ Ibid. 
haknya secara kolektif untuk membangun masyarakat, bangsa dan negaranya;

d. Pasal 28D, hak atas pengakuan, jaminan, perlindungan, dan kepastian hukum yang adil serta perlakuan yang sama dihadapan hukum serta hak untuk bekerja serta mendapat imbalan dan perlakuan yang adil dan layak dalam hubungan kerja, hak memperoleh kesempatan yang sama dalam pemerintahan dan hak atas status kewarganegaraan;

e. Pasal 28E, hak memeluk agama dan beribadat menurut agamanya, memilih pendidikan dan pengajaran, memilih pekerjaan, memilih kewarganegaraan, memilih tempat tinggal di wilayah negara dan meninggalkannya, serta berhak kembali, hak atas kebebasan meyakini kepercayaan, menyatakan pikiran dan sikap, sesuai dengan hati nuraninya, hak atas kebebasan berserikat, berkumpul dan mengeluarkan pendapat;

f. Pasal 28F, hak untuk berkomunikasi dan memperoleh informasi untuk mengembangkan pribadi dan lingkungan sosialnya, serta berhak untuk mencari, memperoleh, memiliki, menyimpan, mengolah, dan menyampaikan informasi dengan menggunakan segala jenis saluran yang tersedia;

g. Pasal 28G, hak atas perlindungan diri pribadi, keluarga, kehormatan, martabat, dan harta benda yang di bawah kekuasaannya, serta berhak atas rasa aman dan perlindungan dari ancaman ketakutan untuk berbuat atau tidak berbuat sesuatu yang merupakan hak asasi, hak untuk bebas dari penyiksaan atau perlakuan yang merendahkan derajat martabat manusia dan berhak memperoleh suaka politik dari negara lain;

h. Pasal $28 \mathrm{H}$, hak hidup sejahtera lahir dan batin, bertempat tinggal, dan mendapatkan lingkungan hidup yang baik dan sehat serta berhak memperoleh pelayanan kesehatan, hak mendapat kemudahan dan perlakuan khusus untuk memperoleh kesempatan dan manfaat 
yang sama guna mencapai persamaan dan keadilan, hak atas jaminan sosial yang memungkinkan pengembangan dirinya secara utuh sebagai manusia yang bermartabat, hak mempunyai hak milik pribadi dan hak milik tersebut tidak boleh diambil alih secara sewenang-wenang oleh siapapun;

i. Pasal 28I, Identitas budaya dan hak masyarakat tradisional dihormati selaras dengan perkembangan zaman dan peradaban, perlindungan, pemajuan, penegakan, dan pemenuhan hak asasi manusia adalah tanggung jawab negara, terutama pemerintah dan nuntuk menegakkan dan melindungi hak asasi manusia sesuai dengan prinsip negara hukum yang demokratis, maka pelaksanaan hak asasi manusia dijamin, diatur, dan dituangkan dalam peraturan perundang-undangan;

j. Pasal 29, Negara menjamin kemerdekaan tiap-tiap penduduk untuk memeluk agamanya masing-masing dan untuk beribadat menurut agamanya dan kepercayaannya itu.

Secara keseluruhan pasal-pasal yang tercantum di dalam konstitusi hampir seluruhnya berkenaan dengan administrasi, sehingga tidak bisa dipungkiri bahwa untuk menjalankan amanat konstitusi tersebut, penyelenggara pemerintah dapat menjalankan hak-hak warga negara tersebut dalam hukum administrasi yang menjamin adanya perlindungan dan kepastian hukum. Sebab pemenuhan hak-hak tersebut menjadi fokus badan-badan administrasi yang membuat peraturan dan keputusan yang nantinya diterapkan kepada masyarakat.

Oleh karena itu, politik hukum dapat dikatakan sebagai suatu disiplin ilmu hukum yang mengatur tentang cara bagaimana merubah ius constitutum menjadi ius constituendum, atau menciptakan hukum baru untuk mencapai tujuan mereka. Selanjutnya kegiatan politik hukum meliputi mengganti hukum dan menciptakan 
hukum baru karena adanya kepentingan yang mendasar untuk dilakukan perubahan sosial dengan membuat suatu regeling (peraturan) bukan beschiking (penetapan). ${ }^{97}$

Sedangkan pada wilayah Politik Hukum Nasional, adalah kebijakkan dasar penyelenggara negara (Republik Indonesia) dalam bidang hukum yang akan, sedang dan telah berlaku, yang bersumber dari nilai-nilai yang berlaku di masyarakat untuk mencapai tujuan negara yang di cita-citakan. Tujuan negara sebagai arah pembangunan nasional sejalan dan berkaitan erat dengan politik hukum yang berlaku dan berubah-ubah. Peranan Politik hukum nasional sangatlah penting dalam mencapai tujuan negara. Hal ini dikarenakan hukum nasional yang akan, sedang dan telah diberlakukan di wilayah yurisdiksi Republik Indonesia dijadikan sebagai pedoman dasar dalam proses penentuan nilai-nilai, penetapan, pembentukan dan pengembangan hukum nasional di Indonesia. ${ }^{98}$

\section{Pemikiran Hak Asasi Manusia dalam Administrasi Negara}

Politik hukum atas pengakuan hak asasi warga negara dalam hukum administrasidi Indonesia sebetulnya berbeda dengan konsep barat maupun konsep sosialis, di mana konsep hak asasi tersebut sangat berbeda penerapannya menyesuaikan ideologi suatu negara masing-masing. Sebelum mengkaji lebih luas, penulis membedakan konsep hak-hak asasi manusia antara Pancasila, Barat, Sosialis menurut pandangan Philipus M Hadjon dapat dilihat dalam bagan sebagai berikut:

97 Mia Kusuma Fitriana, "Peranan Politik Hukum Dalam Pembentukan Peraturan Perundang-Undangan Di Indonesia Sebagai Sarana Mewujudkan Tujuan Negara," Jurnal Legislasi Indonesia 12, no. 2 (2015): 1-27. Hlm. 24.

98 Ibid. 


\begin{tabular}{|c|c|c|c|}
\hline Uraian & $\begin{array}{l}\text { Pengakuan akan harkat } \\
\text { dan martabat manusia } \\
\text { yang bersumber pada } \\
\text { Pancasila }\end{array}$ & Konsep Barat & Konsep Sosialis \\
\hline Sumber & $\begin{array}{l}\text { Secara intersitik melekat } \\
\text { pada Pancasila yang } \\
\text { merupakan Grundnorm }\end{array}$ & $\begin{array}{l}\text { Bersumber } \\
\text { pada hukum } \\
\text { kondrat tetapi } \\
\text { pengakuan } \\
\text { terhadapnya } \\
\text { merupakan } \\
\text { hasil } \\
\text { perjuangan } \\
\text { rakyat } \\
\text { menuntut } \\
\text { haknya } \\
\text { terhadap } \\
\text { negara }\end{array}$ & $\begin{array}{lr}\text { Bersumber } & \text { pada } \\
\text { ajaran } & \text { Karl } \\
\text { Marx } & \end{array}$ \\
\hline Kewajiban & $\begin{array}{l}\text { Adanya hak berbarengan } \\
\text { dengan kewajiban } \\
\text { terhadap masyarakat dan } \\
\text { negara }\end{array}$ & $\begin{array}{l}\text { Mengutamaka } \\
\mathrm{n} \text { hak dan } \\
\text { meletakkan } \\
\text { kewajiban } \\
\text { pada nengara }\end{array}$ & $\begin{array}{l}\text { Mengutamakan } \\
\text { kewajiban } \\
\text { terhadap negara }\end{array}$ \\
\hline
\end{tabular}

Sumber: Philipus M Hadjon, Perlindungan Hukum Bagi Rakyat di Indonesia ${ }^{99}$

Pada pemaknaan secara administratif, Van Apeldorn memberikan makna bahwa politik hukum sebagai politik perundang-undangan. Politik hukum berarti menetapkan tujuan dan isi peraturan perundang-undangan. Pengertian politik hukum terbatas hanya pada hukum tertulis saja. Namun, substansi dari hukum tertulis dimaksudkan

99 Philipus M. Hadjon, Perlindungan Hukum Bagi Rakyat Di Indonesia, ed. PT Bina Ilmu, Cetakan 1 (Surabaya, 1987). Hlm. 67 
direfleksikan pada aplikasi dari ketentuan hukum di dalam penerapan-penerapannya dalam masyarakat. ${ }^{100}$

Sedangkan penerapan dari Politik hukum sebagai kebijakan hukum (legal policy) yang dibuat dan atau telah dilaksanakan secara rasional oleh pemerintah Indonesia, yang dalam impelementasinya meliputi:

a. Pembangunan hukum yang berintikan pembuatan hukum dan pembaharuan terhadap bahan-bahan hukum yang dianggap asing atau tidak sesuai dengan kebutuhan dengan penciptaan hukum yang diperlukan;

b. Pelaksanaan ketentuan hukum yang telah ada, termasuk penegasan fungsi lembaga dan pembinaan para anggota penegak hukum.

Politik hukum juga meliputi sosialisasi hukum yang wujudnya berupa bagaimana hukum disampaikan, kepada siapa disampaikan, apa saja yang disampaikan, dengan cara apa disampaikan, dan apa yang akan dicapai dari kebijakan sosialisasi itu. Sehingga politik hukum HAM dalam hal ini didefinisikan sebagai kebutuhan-kebutuhan hak-hak asasi manusia, kebutuhan-kebutuhan dasar manusia yang membangkitkan suatu hak adalah sesuatu yang logis. Sekaligus sah dan bermanfaat untuk menyatakan kebutuhan-kebutuhan dasar naluriah manusia itu sebagai hak. ${ }^{101}$

Dalam mazhab hukum alam konsepsi dasar hak-hak asasi manusia meliputi tiga hal, yaitu: hak hidup (the right to life). Hak kemerdekaan (the right to liberty) dan hak milik (the right to property). ${ }^{102}$ Sedangkan di dalam ilmu hukum kita berbicara tentang pelaksanaan keadilan (administration of justice) yang berarti mengatur hubungan hubungan dan

100 Samsul Wahidin, Politik Penegakan Hukum Di Indonesia (Yogyakarta: Pustaka Pelajar, 2017). Hlm. 27.

101 Ni'matul Huda, Politik Hukum HAM Indonesia (Yogyakarta: Pascasarjana FH UII, 2010). Hlm. 74.

102 Titik triwulan Tutik, Konstruksi Hukum Tatat Negara Indonesia Pasca Amandemen UUD 1945 (Jakarta: $\quad$ Prenadamedia Group, 2016). Hlm. 281-282 
menertibkan kelakuan manusia di dalam dan melalui pengadilan-pengadilan, dari masyarakat yang berorganisasi politik, sedang boleh para penulis filsafat hukum keadilan itu diartikan sebagai hubungan yang ideal antara manusia. ${ }^{103}$ Sementara pada kultur hukumnya terdapat nilai-nilai dan sikap-sikap yang mempengaruhi tegaknya atau bekerjanya hukum, baik kulutur di dalam internal hukum itu sendiri (Penegak Hukum) maupun kultur eksternal, yaitu budaya masyarakat pada umumnya. ${ }^{104}$

Mengenai budaya masyarakat, hal ini terjadi karena muncul respons masyarakat terhadap kehidupan pemerintahan sehari-hari yang dijalankan melalui kegiatan administrasi negara. Namun, semua itu tentu membutuhkan satu instrumen yang mampu memberi kewenangan atau legalitas atas segala tindakan administrasi negara tersebut. Apabila tidak, tentu akan terjadi ketegangan antara negara dan rakyat. Terlebih, administrasi negara cenderung menerobos privasi masyarakat sehingga untuk memberikan legalitas kegiatan administrasi negara, dibutuhkanlah satu instrumen, yakni hukum administrasi negara tersebut. Pada galibnya, hukum administrasi negara telah menjadi semacam sabuk yang melingkupi segenap kegiatan administrasi. Sabuk hukum ini tidak hanya memberikan legalitas atas semua tindakan administrasi negara, tetapi juga melindungi warga negara dari tindakan administrasi negara. Hukum administrasi negara berusaha menjadi batas sekaligus parameter tindakan tindakan administrasi negara. ${ }^{105}$

103 Nurus Zaman, "Membangun Politik Hukum Administrasi Pemerintahan Yang Bersumber Dari Nilai-Nilai Pancasila," Rechtidee 10, no. 2 (2015): 203-22, https://doi.org/https://doi.org/10.21107/ri.v10i2.1237. Hlm. 215.

104 Suparman Marzuki, Pengadilan HAM Di Indonesia (Yogyakarta: Erlangga, 2012). Hlm. 31.

105 Yos Johan Utama, "Pengertian Administrasi Negara Dan Hukum Administrasi 
Menurut Philipus M Hadjon, suatu inti yang terkandung di dalam hak, yaitu adanya suatu tuntutan (claim), sehingga berbicara tentang hak kita membayangkan bahwa di dalamnya ada suatu "claim" dan dalam kaitannya dengan perlindungan hukum bagi rakyat adanya suatu, "claim" dari rakyat: dan dalam hal ini The Raights of Man Today, mengatakan :

"Hak-hak asasi manusia adalah tuntutan-tuntutan yang dipertahankan yang dikenal "sebagai hak", bukan tuntutan-tuntutan atas cinta, atau rahmat atau persaudaraan, atau cinta kasih: orang tidak harus mendapat atau menerimanya. Tuntutan itu bukan hanya merupakan aspirasi atau pernyataan-pernyataan moral tetapi bahkan merupakan tuntutan hukum berdasarkan hukum tertentu yang dapat diterapkan". 106

Apabila melihat kembali fungsi administratif, sebetulnya dalam wilayah ketatanegaraan muncul suatu proses pemisahan kekuasaan bagaimana administrasi pemerintahan itu berjalan. Seperti V. S. Deshpande menjabarkan bahwa dalam prinsip pemisahan kekuasaan, administrasi umum adalah urusan eksekutif dan lembaga legislatif maupun peradilan. Dalam analisis akhir, Eksekutif bertanggung jawab kepada DPR setiap tindakan administrasinya tunduk pada kontrol Parlemen. Ini berarti bahwa eksekutif bertanggung jawab kepada parlemen. Meskipun hal ini berarti bahwa Parlemen sebenarnya mengganggu tindakan tertentu administrasi eksekutif karena setiap tindakannya harus menurut hukum. Sementara sifat kontrol Parlemen adalah hal yang umum, sifat pengendalian yudisial oleh sifatnya dibatasi untuk kasus-kasus individu. Maka seluruh proses administrasi akan tunduk pada pengawasan peradilan. Oleh karena itu,

106 Hadjon, Perlindungan Hukum Bagi...op.cit., hlm. 39 
tindakan eksekutif itu dapat dikontrol peradilan yang mencakup seluruh bidang administrasi. ${ }^{107}$

Meskipun perbuatan hukum dan hubungan hukum tersebut telah diatur dengan norma-norma hukum, namun tidak selamanya hubungan hukum antar subjek hukum itu berjalan harmonis, seimbang dan adil, atau terlaksana sesuai norma hukum yang berlaku. Dimungkinkan pada saat-saat tertentu ada subjek hukum yang tidak menjalankan kewajibannya secara legal sehingga ada subjek hukum lain yang terganggu atau melanggar hak-haknya, atau ada saat-saat tertentu dalam suatu hubungan hukum salah satu subjek hukum itu dengan sengaja atau karena kelalaiannya melanggar hak subjek hukum lain. Terhadap subjek hukum yang melanggar hak-haknya ini, hukum juga mengatur dan memberi jaminan tentang bagaimana hak-hak tersebut dikembalikan pada subjek hukum yang terlanggar haknya tersebut melalui proses hukum. ${ }^{108}$

\section{Politik Hukum Hak Asasi Manusia di Bidang Administrasi Negara}

Patut diakui memang pada dasarnya definisi hak asasi manusia juga masih menimbulkan perdebatan di sana sini terkait mengenai definisi atas hak asasi manusia tersebut. Namun yang jelas menurut penulis hak asasi manusia dapat terbagi ke dalam beberapa bagian, yaitu:

a. Hak asasi yang terlahir atas pemberian Tuhan yang tidak dapat dibantah lagi keberadaannya seperti hak untuk hidup dan hak asasi lainnya yang bersumber dari Tuhan mengiringi kehidupan manusia;

b. Hak asasi yang bersumber dari pemberian Negara dengan atau tanpa melalui undang-undang, seperti halnya hak atas pendidikan, penghidupan yang layak,

107 V. S. Deshpande, “Administrative Law," Indian Legal System 28, no. 3 (1994): 300-316, https://doi.org/10.1080/03069400.1994.9992903. Hlm. 339.

108 Ridwan, Tiga Dimensi Hukum Administrasi Dan Peradilan Administrasi (Yogyakarta: FH UII Press, 2009). Hlm. 119. 
dan lain sebagainya. Demokratisasi disuatu system pemerintahan. 109

Politik Hukum (Sekarang dan dimasa yang akan datang) harus pula memperhatikan pengaruh global. Dalam konteks global, politik hukum tidak dapat semata-mata melindungi kepentingan nasional, tetapi juga harus melindungi kepentingan internasional atau juga harus melindungi kepentingan lintas negara.

a. Politik hukum mengenai hak cipta, paten dan merek tidak terlepas dari kepentingan hak-hak tersebut yang dimiliki orang-orang asing. Tanpa memperhatikan kepentingan itu, bukan saja mengandung konflik hukum tetapi mungkin konflik politik dan ekonomi antarnegara;

b. Politik hukum perburuan mempengaruhi berbagai isu global seperti HAM, kesejahteraan pekerja, dan sebagainya. Persoalan adalah menerukan, sejauh mana masalah global itu benar-benar merukan suatu tuntutan global, atau sekedar kepentingan negara yang kuat "memaksakan" kehendak dan kepentingan negara lain. ${ }^{110}$

Apabila berkaca pada Peraturan Pemerintah Nomor 68 Tahun 1999 peran serta masyarakat pada Pasal 2 menjelaskan :

a. Peran serta masyarakat dalam penyelenggara negara untuk mewujudkan Penyelenggara Negara yang bersih dilaksanakan dalam bentuk:

1) hak mencari, memperoleh, dan memberikan informasi mengenai penyelenggaraan negara;

2) hak untuk memperoleh pelayanan yang sama dan adil dari Penyelenggara Negara;

109 Fauzan Khairazi, “Implementasi Demokrasi Dan Hak Asasi Manusia Di Indonesia," Jurnal Inovatif 8, no. 1 (2015): 72-94. Hlm. 81

110 Abdul Latif dan Hasbi Ali, Politik Hukum (Jakarta: Sinar Grafika, 2016). Hlm. 167. 
3) hak menyampaikan saran dan pendapat secara bertanggung jawab terhadap kebijakan Penyelenggara Negara; dan

4) hak memperoleh perlindungan hukum dalam hal melaksanakan haknya sebagaimana dimaksud dalam huruf $a, b$, dan c.

Kemudian mengenai Hak-hak lain yang diberikan oleh undang-undang dalam pencegahan korupsi di lingkungan pemerintahan yang dilakukan oleh masyarakat itu sendiri penormaannya terdapat pada Pasal 41 ayat 2 Undang-Undang Republik Indonesia Nomor 31 Tahun 1999 Tentang Pemberantasan Tindak Pidana Korupsi Peran serta masyarakat sebagaimana dimaksud dalam ayat diwujudkan dalam bentuk:

a. hak mencari, memperoleh dan memberikan informasi adanya dugaan telah terjadi tindak pidana korupsi;

b. hak untuk memperoleh pelayanan dalam mencari, memperoleh dan

c. memberikan informasi adanya dugaan telah terjadi tindak pidana korupsi kepada penegak hukum yang menangani perkara tindak pidana korupsi;

d. hak menyampaikan saran dan pendapat secara bertanggungjawab kepada penegak hukum yang menangani perkara tindak pidana korupsi;

e. hak untuk memperoleh jawaban atas pertanyaan tentang laporannya yang diberikan kepada penegak hukum dalam waktu paling lama 30 (tiga puluh) hari;

Selanjutnya pada Pasal 44 Undang-Undang Republik Indonesia Nomor 31 Tahun 1999 juga memberikan penormaan berupa :

"Setiap orang berhak sendiri maupun bersama-sama berhak mengajukan pendapat, permohonan, pengaduan, dan atau usaha kepada pemerintah dalam rangka pelaksanaan pemerintahan yang bersih, efektif, dan efisien, baik dengan 
lisan meupun dengan tulisan sesuai dengan ketentuan peraturan perundang-undangan."

Sedangkan pada Undang-Undang Republik Indonesia Nomor 39 Tahun 1999 Tentang Hak Asasi Manusia Pasal 14 juga menyebutkan bahwa dalam penyelenggaraan administrasi pemerintah itu, warga negara diberikan hak sebagai berikut:

a. Setiap orang berhak untuk berkomunikasi dan memperoleh informasi yang diperlukan untuk mengembangkan pribadinya dan lingkungan sosialnya;

b. Setiap orang berhak untuk mencari, memperoleh, memiliki, menyimpan, mengolah, dan menyampaikan informasi dengan menggunakan segala jenis sarana yang tersedia.

Sehingga apabila dilebur, pemaknaan Hak Asasi Manusia yang terdapat dalam Undang-Undang Nomor 39 Tahun 1999 Tentang Hak Asasi Manusia. Maka dapat dimaknai jika undang-undang tersebut melarang setiap penyelenggara pemerintah untuk tidak melakukan pembatasan, pelecehan, atau pengucilan yang langsung ataupun tak langsung didasarkan pada pembedaan manusia atas dasar agama, suku, ras, etnik, kelompok, golongan, status sosial, status ekonomi, jenis kelamin, bahasa, keyakinan politik, yang berakibat pengurangan, penyimpangan, atau penghapusan pengakuan, pelaksanaan, atau penggunaan hak asasi manusia dan kebebasan dasar dalam kehidupan baik individual maupun kolektif dalam bidang politik, ekonomi, hukum, sosial, budaya dan aspek kehidupan lainnya. ${ }^{111}$

Secara umum, penormaan atas perlindungan hak asasi manusia di patrikan sebagai Asas di dalam Undang-Undang Republik Indonesia Nomor 30 tahun 2014

111 Henni Muchtar, "Analisis Yuridis Normatif Sinkronisasi Peraturan Daerah Dengan Hak Asasi Manusia," Humanus 14, no. 1 (2015): 80, https://doi.org/10.24036/jh.v14i1.5405. Hlm. 83. 
tentang Administrasi Pemerintahan, menunjukkan adanya pengakuan hak-hak asasi manusia oleh pembuat legislasi di setiap norma di dalam peraturan perundang-undang. Hal ini wajib dinormakan tidak lain karena perintah konstitusi itu sendiri.

Sedangkan hak konstitusional yang hubungannya terhadap kepentingan administrasi warga negara tercantum dalam Pasal 28A-28J UUD 1945 yang mengandung arti jelas bahwa, jika ada warga negara tidak mendapatkan haknya atas pendidikan dan pekerjaan, maka warga negara itu bisa menuntut haknya kepada negara. Sebaliknya, jika ada warga negara tidak melaksanakan kewajiban pendidikannya, negara berhak mengenakan sanksi kepada yang bersangkutan. Berangkat dari kete Wintuan di atas, bisa ditarik benang merah bahwa negara menjamin kepada semua warga negaranya tanpa terkecuali untuk memperoleh pendidikan dan pekerjaan layak. ${ }^{112}$

Maka dengan demikian dapat ditarik benang merahnya jika di dalam politik hukum Hak asasi tersebut di dalam negara hukum demokratis harus bersifat promotif, protektif dan implementatif terhadap HAM guna mencegah penyalahgunaan kekuasaan dalam bentuk pelanggaran HAM. Promotif, berarti undang-undang yang dibuat memiliki kekuatan moral dan hukum yang memungkinkan setiap kebijakan, setiap orang dan kekuasaan menghormati dan menghargai HAM. Protektif, berarti undang-undang yang dibuat memiliki daya cegah terhadap pelbagai kemungkinan terjadinya pelanggaran HAM, sementara implementatif, berarti undang-undang yang dibuat harus bisa dilaksanakan atau diterapkan jika terjadi pelanggaran, dan bukan undang-undang yang tidak bisa dilaksanakan, baik karena rumusan pasalnya yang kabur, tidak jelas,

112 Jazim Hamidi, "Perlindungan Hukum Terhadap Disabilitas Dalam Memenuhi Hak Mendapatkan Pendidikan Dan Pekerjaan," Jurnal Hukum IUS QUIA IUSTUM 23, no. 4 (2016): 652-71, https://doi.org/10.20885/iustum.vol23.iss4.art7. Hlm. 654. 
duplikasi atau multi tafsir, maupun karena pelaksanaan undang-undang tidak dindependen. ${ }^{113}$

\section{Hukum Administrasi Negara Melindungi Hak Asasi Warga Negara}

\section{Keberadaan Hukum Administrasi Negara di Indonesia}

Menurut V. S. Deshpand menjelaskan jika ungkapan "Hukum Administrasi" dapat berarti dua hal yang berbeda, yaitu, (a) hukum yang berkaitan dengan administrasi, dan (b) hukum yang dibuat oleh administrasi. Yang terakhir itu sendiri akan terdiri dari dua jenis. Pertama, mungkin aturan, peraturan, perintah, skema, bye-law, dll, dibuat oleh otoritas administrasi kepada siapa yang berkuasa untuk membuat peraturan yang diberikan oleh konstitusi. Ini bisa disebut pembuatan aturan. Kedua, pastinya otoritas administratif memiliki kekuasaan untuk memutuskan tentang hukum dan / atau fakta yang mempengaruhi seseorang atau masyarakat tertentu pada umumnya, yaitu kekuasaan tersebut dilaksanakan secara yudisial. Keputusan semacam itu harus menerapkan undang-undang atau kebijakan administrasi dan instruksi untuk kasus-kasus tertentu. Dengan melakukan itu, maka mereka diharuskan membentuk badan hukum administrasi. ${ }^{114}$

Pembahasan atas usaha pembentukan Peradilan Administrasi Negara berawal dari Rochmat Soematri mengajukan kertas kerja dengan judul Peradilan Tata Usaha Negara dan Perlindungan Hak-Hak Asasi, dan pada akhirnya pada tahun 1982 Pemerintah mengajukan Rancangan Undang-Undang Peradilan Tata Usaha Negara kepada DPR menjelang akhir masa jabatan DPR periode tersebut. Rancangan Undang-Undang tersebut

113 Suparman Marzuki, "Politik Hukum Hak Asasi Manusia (HAM) Di Indonesia Pada Era Reformasi Studi Tentang Penegakan Hukum HAM Dalam Penyelesaian Pelanggaran HAM Masa Lalu," Jurnal Hukum Ius Quia Iustum (Universitas Islam Indonesia, 2000), https://doi.org/10.20885/iustum.vol7.iss14.art1. Hlm. 194.

114 Deshpande, Administrative Law...op.cit., hlm. 333. 
dikembalikan oleh DPR kepada Pemerintah untuk penyusunan kembali. Setelah melalui suatu proses pembahasan yang cukup lama akhirnya pada tanggal 29 Desember 1986 telah diundangkan Undang-Undang Nomor 5 Tahun 1986 tentang Peradilan Tata Usaha Negara. ${ }^{115}$

Setelah beberapa dekade, paradigma hak-hak asasi dalam administrasi negara kembai muncul pada tahun 2003, yaitu dikenal sebagai paradigma New Public Service (NPS) yang dikemukakan oleh Dernhart dan Derhart. Paradigma ini mengkritisi pokok-pokok pemikiran paradigma administrasi negara pro market. Ide pokok paradigma NPS adalah mewujudkan administrasi negara yang menghargai citizenship, demokrasi dan hak asasi manusia. Paradigma NPS memperlakukan publik pengguna layanan publik sebagai warga negara (citizen) bukan sebagai pelanggan (customer). Administrasi negara tidak sekedar bagaimana memuaskan pelanggan tapi juga bagaimana memberikan hak warga negara dalam mendapatkan pelayanan publik. Cara pandang paradigma NPS ini, menurut Dernhart diilhami oleh:

a. Teori politik demokrasi terutama yang berkaitan dengan relasi warga negara (citizens) dengan pemerintah, dan;

115 Pembentukan Peradilan Administrasi Negara di Indonesia dibagi atas dua periode berdasarkan masa berlakunya undang-undang Ketentuan Pokok Kekuasaan Kehakiman, yaitu Undang-Undang No. 19 Tahun 1964 yang diganti oleh Undang-Undang No. 14 Tahun 1970. Pada masa berlakunya, tidak nampak langkah-langkah yang pasti ke arah pembentukan peradilan administrasi negara. Suatu langkah usaha yang dilakukan Lembaga Pembinaan Hukum Nasional Departemen Kehakiman (sekarang BPHN) adalah menyusun konsep mengenai RUU Peradilan Tata Usaha Negara. Pada masa persiapan dan pembahasan RUU No 14 Tahun 1970, Peradilan Tata Usaha Negara merupakan salah satu topik yang ramai dibicarakan. Namun sayangnya setelah itu untuk suatu jangka waktu 5 tahun tidak ada tanda-tanda usaha ke arah pembentukan Peradilan Administrasi. Usaha ke arah pembentukan Peradilan Administrasi menampakkan diri ke permukaan pertama dengan diselenggaranya suatu simposium tentang Peradilan Tata Usaha Negara tahun 1967 dan pada tahun 1982 Pemerintah mengajukan kepada Dewan Perwakilan Rakyat sebuah RUU tentang Peradilan Tata Usaha Negara. Selanjutnya (Philipus M. Hadjon, Perlindungan Hukum...op.cit., hlm. 173-180) 
b. Pendekatan humanistik dalam teori organisasi dan manajemen. ${ }^{116}$

Berkaitan paradigma Dernhart di atas, maka menurut penulis mengutip Sri Nur hal ini berkenaan dengan prinsip prosedural yang menyatakan bahwa keputusan-kepurusan yang merugikan atau mengurangi Hak-hak seorang Warga Negara/Badan/Negara tidak boleh diambil sebelum memberi kesempatan secukupnya kepada yang bersangkutan untuk membela kepentingannya secara adil dan wajar. Sedangkan beberapa prinsip good governance dalam perkembangannya telah memiliki dasar dalam prinsip supremasi hukum (good governance dan hak asasi manusia), dalam prinsip demokrasi (good governance dan prinsip transparan dan partisipatif) dan dalam prinsip-prinsip efisien, efektif dan akuntabel. Prinsip-prinsip good governance dengan demikian tidak terpisah dan harus dilihat serta ditafsirkan bersamaan dengan prinsip-prinsip negara konstitusional yang demokratis. ${ }^{117}$

2. Perlindungan Hukum Warga Negara Berdasarkan Pengakuan Hak Asasi Manusia

Bagi pemikir hukum administrasi sebetulnya pengakuan hak-hak warga negara telah dirumuskan sejak tahun 1950 oleh pemerintah Belanda membentuk komisi yang diketuai oleh Mr. De Monchy yang bertugas menyelidiki cara-cara perlindungan hukum bagi penduduk/ rakyat. Komisi ini telah berhasil menyusun asas-asas umum untuk pelaksanaan suatu pemerintahan yang baik yang diberi nama "General Principle of Good Government"

Adapun asas-asas umum tersebut adalah :

116 Rakhmat, Hukum Administrasi...op.cit., hlm. 29-36.

117 Sri Nur Hari Susanto, "Good Governance Dalam Konteks Hukum Administrasi," Adminitrative Law $\mathcal{E}$ Governance Journal 2, no. 2 (2019): 206-17. Hlm. 208-212. 
a. Asas Kepastian Hukumartinya didalam pemerintah menjalankan wewenagnya haruslah sesuai dengan aturan-aturan hukum yang telah ditetapkannya. Pemerintah harus menghormati hak-hak seseoang yang diperoleh dari pemerintah dan tidak boleh ditarik kembali;

b. Asas Kesamaan artinya pemerintah dalam menghadapi kasus yang sama/ fakta yang sama, pemerintah harus bertindak yang sama tidak ada perbedaan, tidak ada pilih kasih dan lain sebagainya;

c. Asas Bertindak Cermat artinya pemerintah senantiasa bertindak secara hati-hati agar tidak menimbulkan kerugian bagi warga masyarakat;

d. Asas Fair Play artinya pemerintah harus memberikan kesempatan yang layak kepada warga masyarakat untuk mencari kebenaran dan keadilan;

e. Asas Meniadakan Akibat-Akibat Suatu Keputusan Yang Batal artinya Asas ini menghendaki jika terjadi pembatalan atas suatu keputusan, maka yang bersangkutan harus diberi ganti rugi atau rehabilitasi;

f. Asas Penyelenggraan Kepentingan Umum artinya tugas pemerintah untuk mendahulukan kepentingan umu daripada kepentingan pribadi. ${ }^{118}$

Implementasi dari asas-asas di muka telah dijadikan suatu norma yang mengikat bagi penyelenggara negara, sebagaimana telah secara eksplisit tertulis pada Bab III Pasal 3 Undang-Undang Nomor 28 Tahun 1999 menyebutkan, asas-asas umum terdapat suatu asas yang memberikan hak kepada warga negara, yaitu Asas Keterbukaan adalah asas yang membuka diri terhadap hak masyarakat untuk memperoleh informasi yang benar, jujur, dan tidak diskriminatif tentang penyelenggaraan Negara dengan tetap

118 Bewa Ragawino, “Hukum Administrasi Negara," 2006, http://pustaka.unpad.ac.id/wp-content/uploads/2009/05/hukum_adminis trasi_negara.pdf. Akses 8 Juni 2020. 
memperhatikan perlindungan atas hak asasi pribadi, golongan, dan rahasia Negara.

Sedangkan pada prinsipnya, hubungan antara Pemerintah dan Rakyat dengan berlandaskan pada falsafah dan ideologi negara Pancasila. Asas yang melandasi hubungan antara Pemerintah dan rakyat adalah asas keserasian yang bertumpu atas asas kerukunan. Dengan asas tersebut tidak berarti bahwa tidak mungkin terjadi sengketa antara pemerintah dan rakyat. Asas keserasian hubungan antara pemerintah dan rakyat tidak hanya berlaku bagi pemerintah dalam hubungannya dengan rakyat, tetapi juga menjadi landasan bagi Peradilan Administrasi Negara. 119 Karena penyelenggaraan pemerintahan bertumpu pada sumber daya administrasi yang berlandaskan peraturan perundang-undangan yang berlaku, sehingga peran administrasi negara dapat bergerak sesuai dengan kebutuhan warga negara.

Pada persoalan tersebut relevan untuk membahas pendapat Goerl 1980, yang mengemukakan adanya tiga macam peranan administrator publik yakni (1) sebagai birokrat, (2) sebagai aktor politik, dan (3) sebagai profesional. Sebagai birokrat administrator publik ditengarai sebagai pelaksana kebijakan yang telah dirumuskan oleh superior politiknya (pembuat kebijakan), sehingga dalam peran ini tidak memiliki peran politik, tetapi semata-mata sebagai instrumen yang mempunyai tanggung jawab administratif (administrative responsibility) belaka. Ia hanya sebagai pelaksana kepentingan publik dan bukan berperanan dalam menerjemahkan atau merumuskan kepentingan publik tersebut. Sebagai aktor politik, administrator publik mempunyai peranan untuk berusaha memuaskan kepentingan publik atas dasar nilai-nilai kemanusiaan dan selalu mempertahankan kepentingan pihak yang lemah posisinya (miskin materiil atau power). Dalam posisi ini menunjuk pada keperanannya dalam

119 Hadjon, Perlindungan Hukum...op.cit., hlm. 183-184 
proses perumusan kebijakan publik, artinya dalam menjalankan peran politiknya administrator publik selalu disemangati dengan kepentingan publik (public-spirited-administrator). Sedangkan sebagai professional, administrator publik dipesyaratkan untuk memiliki kemampuan teknis fungsional untuk menjalankan tugasnya dan selalu berorientasi pada pemberian pelayanan yang prima kepada masyarakat berdasarkan pada etika profesionalnya. Secara singkat dapat dika-takan, bahwa sesuai dengan profesionalisme yang dimiliki, administrator publik berfungsi dan mempunyai posisi sebagai perumus kebijakan publik yang berorientasi kepada kepentingan publik. ${ }^{120}$

Salah satu yang menjadi perosalan adalah bagaimana perlindungan hukum bagi masyarakat, diartikan bahwa hukum melindungi kepentingan seseorang dengan cara mengalokasikan suatu kekuasaan kepadanya untuk bertindak dalam rangka kepentingannya tersebut. Pengalokasian kekuasaan ini dilakukan secara terukur, dalam arti, ditentukan keluasan dan kedalamannya. Kekuasaan yang demikian itulah yang disebut hak. Tetapi tidak di setiap kekuasaan dalam masyarakat bisa disebut sebagai hak, melainkan hanya kekuasaan tertentu yang menjadi alasan melekatnya hak itu pada seseorang. Teori tentang perlindungan hukum bagi hak-hak rakyat dikemukakan oleh John Locke tahun 1691 dalam teori kontrak sosial sebagaimana dikutip dalam buku Bernard L Tanya, dkk, menyatakan bahwa ketika membentuk negara dalam teori kontrak sosial, hak-hak tersebut tidak ikut diserahkan kepada penguasa ketika kontrak sosial dilakukan. Oleh karena itu kekuasaan penguasa yang diberikan lewat kontrak sosial, dengan sendirinya tidak mungkin bersifat mutlak. Kalau begitu adanya kekuasaan

120 Badan Pembinaan Hukum Nasional, "Draf Laporan Kompendium Bidang Hukum Administrasi," 2008 ,

https://www.bphn.go.id/data/documents/kompedium_hukum_administra si.pdf. Akses 8 Juno 2020. 
tersebut justru untuk melindungi hak-hak kodrat dimaksud dari bahaya-bahaya yang mungkin mengancam, baik yang datang dari dalam maupun dari luar. Begitulah, hukum yang dibuat dalam negara pun bertugas melindungi hak-hak dasar tersebut. ${ }^{121}$

Sedangkan agar masyarakat tahu negara betul-betul melindungi hak-hak warga negara sehingga sudah tepat jika pada hakikatnya hukum administrasi adalah hukum yang berkaitan dengan kontrol kekuasaan pemerintah. Bagaimanapun juga, adalah jantung dari subjek. Tujuan utama hukum administrasi adalah untuk menjaga kekuasaan pemerintah dalam batas-batas hukum mereka, sehingga dapat melindungi warga negara dari pelecehan mereka. Mesin otoritas yang kuat harus dicegah agar tidak mengamuk. ${ }^{122}$

Pada pihak yang menjadi subjek hukum tersebut maka masyarakat harus mengetahui apa-apa saja bentuk perlindungan hukum bagi warga negara dari tindakan pemerintahan sebagai berikut:

a. Perlindungan hukum dalam rangka menjamin tepenuhinya hak-hak warga negara;

b. Perlindungan hukum dalam rangka mencegah terjadinya tindakan yang merugikan hak-hak warga negara;

c. Perlindungan hukum menyediakan akses bagi warga negara untuk menghentikan tindakan pelanggaran, mendapatkan ganti kerugian atau tindakan pemulihan atas pelanggaran haknya;

121 L Y Hari S I H Advianto, "Pengakuan Dan Perlindungan Hukum Hak Hak Wajib Pajak Dalam Sistem Hukum Pajak Indonesia" (Simposium Nasional Keuangan Negara, 2018). Hlm. 403.

122 Carol Harlow, "Global Administrative Law: The Quest for Principles and Values," The European Journal of International Law 17, no. 1 (2006): 187-214, https://doi.org/10.1093/ejil/chi158. 
1) Perlindungan hukum menjamin tersedianya ganti kerugian atau tindakan pemulihan terhadap hak warga negara yang telah dirugikan. ${ }^{123}$

Menurut Paton, suatu kepentingan merupakan sasaran hak, bukan hanya karena ia dilindungi oleh hukum, melainkan juga karena ada pengakuan terhadap itu. Hak tidak hanya mengandung unsur perlindungan dan kepentingan, tapi juga kehendak. Terkait fungsi hukum untuk memberikan perlindungan, Lili Rasjidi dan B. Arief Sidharta mengatakan bahwa hukum itu ditumbuhkan dan dibutuhkan manusia justru berdasarkan produk penilaian manusia untuk menciptakan kondisi yang melindungi dan memajukan martabat manusia serta untuk memungkinkan manusia menjalani kehidupan yang wajar sesuai dengan martabatnya. ${ }^{124}$

Dewasa ini badan-badan yang menangani perlindungan hukum bagi rakyat (represif) meliputi : rechtspraak van de gowenen rechter (di Belanda menangani perlindungan hukum bagi rakyat dengan mendasarkan kompetensinya sehubungan dengan onrechtmatige overheidsdaad), administratif rechtspraak, administratief beroep (bagian dari administrasi yang dapat melakukan pengujian/toetsing terhadap tindakan pemerintah), nationale ombudsman (melakukan toetsing atas dasar norma-norma kepatutan). ${ }^{125}$

Sehinga perlindungan hak asasi warga negara di bidang administrasi negara tidak hanya menjadi teks di dalam setiap kebijakan atau peraturan yang dibuat pemerintah baik di pusat maupun di daerah yang hanya mengakui kebebasan berdemonstrasi (mengutarakan pendapat) saja, atau diperbolehkan hanya sebatas

123 "Perlindungan Hukum Atas Dikeluarkannya Peraturan Kebijaksanaan Ditinjau Dari Perspektif Hukum Administrasi," http://e-journal.uajy.ac.id/16445/3/HK117992.pdf. Akses 8 Juni 2020.

124 Ibid.

125 Hadjon, Perlindungan Hukum...op.cit., hlm. 9-10 
membentuk suatu perkumpulan. Namun hak-hak yang diatur di dalam konstitusi yang dijalankan oleh badan-badan administrasi, seperti hak untuk bekerja, mendirikan tempat peribadatan, mendapatkan layanan kesehatan, mendapatkan pendidikan, administrasi kependudukan dan hak untuk memajukan perekonomiannya melalui penyelenggara pelayanan publik harus dapat berjalan dengan baik.

Menurut Forsyth di dalam tulisannya berjudul Administrative Law and Human Rights menjelaskan sebagai berikut:

"The task of administrative law, in general, is to impose the values of the rule of law upon that exercise of discretionary powers to ensure that that the powers vested in public authorities are not abused. But the particular task of administrative law in the era of human rights protection is to ensure that those powers are not exercised in a way that impinges upon the human rights of those affected."126

Menurut pemaknaan tersebut, bahwa kekuasaan kepada penguasa sudah saatnya masuk kedalam era perlindungan hak asasi manusia yang khusus fokus pada hukum administrasi negara. Hukum administrasi negara dapat memagari nilai-nilai aturan pada pelaksaan kepada otoritas publik. Tujuannya adalah untuk memastikan bahwa pemegang kekuasaan yang memiliki kekuatan yang diberikan oleh hukum tidak melanggar hak-hak warga negara. Hal ini karena antara individu dan negara di bidang hak asasi manusia adalah paradigma hukum publik. Jaminan hak asasi manusia pada dasarnya adalah kewajiban hukum vertikal, karena hal ini berarti tentang sejauh mana perlindungan kepada masyarakat dijalankan atas perintah

126 Forsyth, "Reconciling the Protection of Human Rights with the Principles of Administrative Law," https://www.venice.coe.int/SACJF/2009_08_BTW_Kasane/speeches/Forsyt h_Administrative Law and Human Rights.pdf. akses 8 Juni 2020. 
konstitusi yang bersifat horisontal, antara pemerintah dengan individu tersebut. ${ }^{127}$

Dengan demikian, patutlah apabila hukum administrasi negara dapat melindungi hak-hak asasi warga negara, hal serupa juga dituliskan oleh Janina Boughey yang mengatakan jika hukum administrasi telah terbukti menjadi kendaraan yang mampu mempromosikan hak asasi manusia dalam banyak situasi. Namun, ada juga keadaan di mana konsep hukum administrasi keadilan prosedural dan kesalahan yurisdiksi gagal melindungi beberapa hak yang paling mendasar. Walaupun hukum administrasi sangat fleksibel, ia dibatasi oleh beberapa batasan mendasar yang memiliki dasar dalam aturan hukum dan konstitusi. Tentu saja ada ruang untuk tantangan batas-batas konsep-konsep ini, yang meliputi pemisahan kekuasaan dan perbedaan antara hukum dan jasa, namun untuk menjaga integritas hukum administrasi, batas-batas ini tidak bisa diabaikan. Bagian artikel ini mempertimbangkan beberapa batasan konseptual pada kemampuan hukum administrasi untuk melindungi hak asasi manusia dalam segala keadaan: pemisahan kekuasaan, perbedaan antara hukum dan jasa dan kesulitan yang dimiliki hukum administrasi dalam mengatur aktor swasta, bahkan ketika menggunakan kekuatan publik. ${ }^{128}$

\section{Penutup}

Politik hukum mengenai Hak-Hak Asasi Manusia di Indonesia didasarkan oleh konsep Pancasila, yaitu adanya hak berbarengan dengan kewajiban terhadap masyarakat dan negara yang dalam pelaksanaan ketentuan hukum yang telah ada, termasuk penegasan fungsi lembaga dan pembinaan para anggota penegak hukum. Sedangkan secara khusus terdapat pedoman

127 Ibid.

128 Janina Boughey, "The Use of Administrative Law to Enforce Human Rights," Australian Journal of Administrative Law 17, no. 1 (2010): 25-38. Hlm. 32. 
yang tetap dipegang teguuh dalam pelaksanaannya dari pemerintah masih menggunakan Peraturan Pemerintah Nomor 68 Tahun 1999 peran serta masyarakat yang kemudian di normakan kembali di dalam Undang-Undang Republik Indonesia Nomor 31 Tahun 1999 tentang Pemberantasan Tindak Pidana Korupsi Peran serta masyarakat, kemudian secara khusus UU No. 39 Tahun 1999 tentang Hak Asasi Manusia, dari beberapa penormaan tersebut kemudian dalam administrasi pemerintah atas Undang-Undang Republik Indonesia Nomor 30 tahun 2014 tentang Administrasi Pemerintahan menunjukkan adanya pengakuan Hak-Hak Asasi Manusia oleh pembuat legislasi di setiap norma di dalam peraturan perundang-undang. Hal ini wajib dinormakan tidak lain karena perintah konstitusi itu sendiri.

Perlindungan hukum agar masyarakat tahu negara betul-betul melindungi hak-hak warga negara sehingga sudah tepat jika pada hakikatnya hukum administrasi adalah hukum yang berkaitan dengan kontrol kekuasaan pemerintah, suatu kepentingan merupakan sasaran hak, bukan hanya karena ia dilindungi oleh hukum, melainkan juga karena ada pengakuan terhadap itu. Hak tidak hanya mengandung unsur perlindungan dan kepentingan, tapi juga kehendak. Hukum administrasi telah terbukti menjadi kendaraan yang mampu mempromosikan Hak Asasi Manusia dalam banyak situasi. Sehingga tidak hanya pada perlindungan hukum yang tertulis di dalam peraturan perundang-undangan, tetapi juga harus memberikan perlindungan hukum di wilayah yudikatif yang harus menghadirkan kepastian hukum (rechtsmatigheid) sebagai benteng terakhir dari keberaadaan konsep administrasi negara yang berkeadilan. 


\section{Daftar Pustaka}

\section{Buku}

Advianto, L Y Hari S I H. “Pengakuan Dan Perlindungan Hukum Hak Hak Wajib Pajak Dalam Sistem Hukum Pajak Indonesia." 2018.

Ali, Abdul Latif dan Hasbi. Politik Hukum. Jakarta: Sinar Grafika, 2016.

El-Muhtaj, Majda. Hak Asasi Manusia Dalam Konstitusi Indonesia Dari UUD1945 Sampai Dengan Amandemen UUD 1945 Tahun 2002. Jakarta: Kencana, 2005.

Hadjon, Philipus M. Perlindungan Hukum Bagi Rakyat Di Indonesia. Edited by PT Bina Ilmu. Cetakan 1. Surabaya, 1987.

HR, Ridwan. Hukum Administrasi Negara. Jakart: PT Rajagrafindo Persada, 2017.

Huda, Ni'matul. Politik Hukum HAM Indonesia. Yogyakarta: Pascasarjana FH UII, 2010.

Marzuki, Suparman. Pengadilan HAM Di Indonesia. Yogyakarta: Erlangga, 2012.

Manan, Bagir. Kedaulatan Rakyat Hak Asasi Manusia Dan Negara Hukum. Jakarta: Radar Jaya, 1996.

MD, Moh. Mahfud. Politik Hukum Di Indonesia. Jakarta: PT Raja Grafindo Persada, 2017.

Mertokusumo, Sudikno. Mengenal Hukum Suatu Pengantar. Yogyakarta: Liberty, 1999. 
Ridwan. Tiga Dimensi Hukum Administrasi Dan Peradilan Administrasi. Yogyakarta: FH UII Press, 2009.

Sujata, Antonius. Reformasi Dalam Penegakan Hukum. Jakarta: Djambatan, 2000.

\section{Jurnal}

Boughey, Janina. "The Use of Administrative Law to Enforce Human Rights." Australian Journal of Administrative Law 17, no. 1 (2010): 25-38.

Deshpande, V. S. “Administrative Law." Indian Legal System 28, no. 3 300-316. https://doi.org/10.1080/03069400.1994.9992903.

Fitriana, Mia Kusuma. "Peranan Politik Hukum Dalam Pembentukan Peraturan Perundang-Undangan Di Indonesia Sebagai Sarana Mewujudkan Tujuan Negara." Jurnal Legislasi Indonesia 12, no. 2 (2015): 1-27.

Hamidi, Jazim. "Perlindungan Hukum Terhadap Disabilitas Dalam Memenuhi Hak Mendapatkan Pendidikan Dan Pekerjaan." Jurnal Hukum IUS QUIA IUSTUM 23, no. 4 (2016):

$652-71$

https://doi.org/10.20885/iustum.vol23.iss4.art7.

Harlow, Carol. "Global Administrative Law: The Quest for Principles and Values." The European Journal of International Law 17, no. 1 (2006): $187-214$. https://doi.org/10.1093/ejil/chi158.

Khairazi, Fauzan. "Implementasi Demokrasi Dan Hak Asasi Manusia Di Indonesia." Jurnal Inovatif 8, no. 1 (2015): 72-94. 
Lubis, Todung Mulya. "Menegakkan Hak Asasi Manusia, Menggugat Dlskriminasi." Jurnal Hukum \& Pembangunan 39, no. 1 (2009): 58. https://doi.org/10.21143/jhp.vol39.no1.204.

Marzuki, Suparman. "Politik Hukum Hak Asasi Manusia (HAM)

Di Indonesia Pada Era Reformasi Studi Tentang Penegakan Hukum HAM Dalam Penyelesaian Pelanggaran HAM Masa Lalu." Jurnal Hukum IUS QUIA IUSTUM. Universitas Islam Indonesia, 2000. https://doi.org/10.20885/iustum.vol7.iss14.art1.

Muchtar, Henni. "Analisis Yuridis Normatif Sinkronisasi Peraturan Daerah Dengan Hak Asasi Manusia." Humanus 14, no. 1 (2015): 80. https:/ / doi.org/10.24036/jh.v14i1.5405.

Susanto, Sri Nur Hari. "Good Governance Dalam Konteks Hukum Administrasi." Adminitrative Law \& Governance Journal 2, no. 2 (2019): 206-17.

Tutik, Titik triwulan. Konstruksi Hukum Tatat Negara Indonesia Pasca Amandemen UUD 1945. Jakarta: Prenadamedia Group, 2016.

Wahidin, Samsul. Politik Penegakan Hukum Di Indonesia. Yogyakarta: Pustaka Pelajar, 2017.

Zaman, Nurus. "Membangun Politik Hukum Administrasi Pemerintahan Yang Bersumber Dari Nilai-Nilai Pancasila." Rechtidee 10, no. 2 (2015): 203-22. https://doi.org/https://doi.org/10.21107/ri.v10i2.1237.

\section{Internet}

Badan Pembinaan Hukum Nasional. "Draf Laporan Kompendium Bidang Hukum Administrasi," 2008. https://www.bphn.go.id/data/documents/kompedium_h ukum_administrasi.pdf. 
Forsyth. "Reconciling the Protection of Human Rights with the Principles of Administrative Law," n.d. https://www.venice.coe.int/SACJF/2009_08_BTW_Kasane /speeches/Forsyth_Administrative Law and Human Rights.pdf.

"Perlindungan Hukum Atas Dikeluarkannya Peraturan Kebijaksanaan Ditinjau Dari Perspektif Hukum Administrasi," n.d. http:/ /e-journal.uajy.ac.id/16445/3/HK117992.pdf.

Ragawino, Bewa. "Hukum Administrasi Negara," 2006. http:// pustaka.unpad.ac.id/wp-content/uploads/2009/05 /hukum_administrasi_negara.pdf.

Rakhmat, Muhamad. "Hukum Administrasi Negara Indonesia," n.d.

http://www.jurnal.unma.ac.id/index.php/RBJ/article/vie wFile/531/495.

Yos Johan Utama. "Pengertian Administrasi Negara Dan Hukum Administrasi Negara." $\quad$ Modul, 2012. http://repository.ut.ac.id/3974/1/ADPU4332-M1.pdf.

Wahjono, Padmo. Masalah Ketatanegaraan Indonesia Dewasa Ini. Jakarta: Ghalia Indonesia, 1984. 
POLITIK HUKUM PENGELOLAAN,

PERTANGGUNGJAWABAN, DAN PENGAWASAN

DANA DESA

\section{Rheza Firmansyah}

Staf Pengawasan Badan Pengawas Pemilu Daerah Istimewa

Yogyakarta

Jl. DI Panjaitan No.49, RT.03, Mantrijeron, Kec. Mantrijeron, Kota

Yogyakarta, Daerah Istimewa Yogyakarta 55143

Email : rhezafirmansyah95@gmail.com

\section{A. Pendahuluan}

Dianutnya desentralisasi dalam organisasi negara tidak berarti ditinggalkannya asas sentralisasi, karena kedua asas tersebut tidak bersifat dikotomi melainkan kontinum. Pada prinsipnya, tidaklah mungkin dieselenggrakkan desentralisasi tanpa sentralisasi. Sebab desentralisasi tanpa sentralisasi, akan menghadirkan disentegrasi. Ada beberapa hal yang menjadi otoritas dari pusat (Jakarta) yakni pertahanan keamanan, masalah keagamaan, moneter fiscal, peradilan, dan hubungan luar negeri. Selain hal tersebut maka kewenangannya diserahkan dan didistribusikan ke daerah daerah berdasarkan peraturan perundang-undangan yang mengaturnya. Oleh karena itu otonomi daerah yang pada hakikatnya mengandung kebebasan dan keleluasaan berprasangka, memerlukan bimbingan dan pengawasan Pemerintah pusat dalam pelaksanaanya. Otonomi daerah diadakan bukan sekedar menjamin efisiensi penyelenggaraan pemerintahan. Bukan sekedar menampung kenyataan negara yang luas, penduduk banyak, dan pulau- pulau. Lebih dari itu, otonomi daerah merupakan dasar memperluas pelaksanaan demokrasi dan instrument mewujudkan tujuan negara yakni mengusahakan kesejahteraan umum. ${ }^{129}$

129 Bagir Manan, Menyongsong Fajar Otonomi Daerah (Yogyakarta: Pusat Studi Hukum Fakultas Hukum Universitas Islam Indonesia, 2001) hlm 4. 
Pasca diundangkannya Undang-Undang Nomor 6 Tahun 2014 yang mengatur tentang pemerintahan desa, secara tidak langsung desa telah diberikan wewenang otonomi untuk mengatur urusan rumah tangganya sendiri. Namun pasca dundangkan Undang-Undang tentang pemerintahan desa tersebut, diberlakukan dan dimasukkan ke dalam Lembaran Negara Republik Indonesia Nomor 5495, ternyata harapan yang tertuang di dalam Undang-Undang Nomor 6 tahun 2014 tersebut agar desa berdaya dengan sendirinya ternyata belum bisa memberikan dampak yang signifikan terhadap perkembangan desa-desa yang ada di Indonesia ini, atau boleh dikatakan otonomi desa ini bidang disebut kurang maksimal dan dapat mengundang potensi kegagalan bila hal ini tidak diperhatikan secara seksama baik melalui mekanisme pemerintah daerah yang bersinggungan langsung dengan pemerintahan desa ataupun pemerintah pusat yang dalam hal ini berperan sebagai decision maker pembuat kebijakan.

Dalam Undang-Undang Nomor 6 Tahun 2014 telah dicantumkan mengenai pengelolaan dana desa tersebut yang bersumber dari Anggaran Pendapatan Belanja Negara dan juga sebagai sumber Keuangan Desa dapat didapatkan dari Badan Usaha Milik Desa (Selanjutnya disebut BUMDes). Adanya dana desa yang bersumber dari APBN (Anggaran Pendapatan Belanja Negara) tentu sangat membantu dalam perencanaan pembangunan daerah tertinggal, akan tetapi adanya dana desa tersebut juga dapat menimbulkan masalah baru di dalam tata kelola Keuangan Negara, jika salah dalam pengelolaan dan menimbulkan kerugian terhadap Negara, maka kekeliruan tersebut dapat berujung pada tindak pidana korupsi mengingat dana desa termasuk dana dengan jumlah yang besar dan digelontorkan langsung melalui APBN. Sehingga dengan jumlah yang besar maka, dana tersebut perlu adanya pengawasan dan pengelolaan yang baik supaya tidak terjadi kesalahan dan berujung pada tindak pidana.

Dana desa bukanlah dana yang sedikit, menurut Direktur jenderal (Dirjen) Kementrian Keuangan Negara tahap 
penyaluran dana desa memiliki pagu anggaran sebesar Rp 20 Triliun pada RAPBN (Rancangan Anggaran Pendapatan Belanja Negara) 2015 dan akan ditransfer langsung Kementerian Keuangan pada pemerintah Kabipaten/Kota, setelah itu Bupati atau Walikota yang membaginya kepada seluruh desa. Mekanisme penyaluran tersebut sebagaimana yang diatur di dalam Peraturan Pemerintah Nomor 60 Tahun 2014 tentang Dana Desa yang bersumber dari APBN. Dalam Pasal 1 dan 2 Peraturan Pemerintah Nomor 60 Tahun 2016 mengatakan dana desa disalurkan oleh pemerintah kepada kabupaten/kota dari Rekening Kas Umum Negara (RKUN) kemudian ditransfer ke Rekening Kas Umum Daerah (RKUD). ${ }^{130}$ Secara normatif hal ini memang tidak terjadi masalah, namun apabila norma-norma ini diterapkan ke masyarakat desa bukan tidak mungkin menimbulkan masalah yang amat serius seraya mempertimbangkan kemampuan kepala desa beserta perangkatnya membuat Rancangan Anggaran Pendapatan Belanja Desa (Selanjutnya disebut RAPBDes). Dalam hal ini Komisi Pemberantasan Korupsi (KPK) mengingatkan penyaluran dana desa rawan terjadi korupsi dan salah sasaran dalam penyaluran dana desa ke desa- desa yang hendak dituju, termasuk transformasi yang terjadi setelah dana desa tersebut disalurkan. ${ }^{131}$ Dapat disimpulkan bahwa dengan adanya dana desa ini KPK dapat menjangkau elemen pemerintahan yang paling rendah dari NKRI yakni pemerintah desa jika menyalahgunakan wewenang dan merugikan negara dengan jumlah dana desa yang begitu besarnya.

Maka dalam hal ini penting untuk diperhatikan oleh pemerintah agar dana desa ini tepat sasaran. Pendampingan terhadap perangkat desa diperlukan agar para perangkat desa pun tahu bagaimana memanfaatkan dana desa untuk kepentingan transformasi sosial di sebuah desa agar desa

130 Pasal (1) dan (2) PP Nomor 60 Tahun 2016 Tentang Dana Desa yang Berasal Dari APBN.

131 Kompas, Sabtu 29 November 2014 
menjadi lebih baik dan menjadi desa yang berdaya dengan sendirinya. ${ }^{132}$ Berdasarkan latar belakang yang telah dijelaskan di atas, maka penulis mengambil dua pokok rumusan masalah yakni, bagaimana mekanisme pengelolaan dan pertanggungjawaban dana desa dan bagaimana politik hukum penataan pengelolaan, pertanggungjawaban dan pengawasan dana desa?

\section{B. Mekanisme Pengelolaan dan Pertanggungjawaban Dana Desa}

Pasca berlakunya Undang-Undang Nomor 6 Tahun 2014 tentang Desa, Desa sudah dipastikan tidak lagi mempunyai permasalahan di dalam maslah pendanan. Hal ini dikarenakan dengan adanya Undang-Undang Nomor 6 Tahun 2014 desa sudah memiliki dasar hukum sebagaimana sama dengan pemerintah daerah yang diatur oleh Undang-Undang tersendiri. Berkalunya Undang-Undang Nomor 6 Tahun 2014 tentang Desa tentu memberikan dampak yang sangat signifikan bagi perkembangan masyarakat desa dan Pemerintahan desa pada khususnya. Salah satu mengapa ada perubahan yang sangat signifikan adalah mengenai dana desa.

Dana desa sebagaimana diatur di dalam Undang-Undang Nomor 6 Tahun 2014 telah memberikan dampak yang cukup signifikan di dalam Pemerintahan desa tersebut. Sebelumnya desa yang kurang diperhatikan oleh pemerintah daerah bahkan pemerintah pusat. Kini diberikan pengakuan secara yuridis dan diberdayakan pula secara yuridis melalui adanya dana desa. Dana desa inilah yang kemudian bersumber langsung dari Anggaran dan Pendapatan Belanja Negara ditransfer melalui Anggaran Pendapatan dan Belanja Daerah Kabupaten/Kota yang digunakan untuk membiayai penyelenggaraan pemerintahan, pelaksanaan pembangunan, pembinaan kemasyarakatan, dan

132 Nimatul Huda, Hukum Pemerintahan Desa,(Malang: Setara Press 2015) hlm 235 . 
pemberdayaan masyarakat. ${ }^{133}$ Ini adalah merupakan lompatan yang sangat progresif di sektor otonomi, Pembuat Undang-Undang percaya desa mampu tumbuh dan berkembang dengan adanya Undang-Undang Nomor 6 Tahun 2014 .

Sebagai konsekuensi logis dari dana desa yang bersumber dari APBN tentunya dana desa masuk ke dalam sistem pengelolaan keuangan negara. Secara yuridis menganai keuangan negara dimaknai dengan semua hak dan kewaiban negara yang dapat dinilai dengan uang serta segala sesuatu baik berupa uang maupun berupa barang yang dapat dinilai dengan uang, serta segala sesuatu baik berupa uang maupun berupa barang yang dapat dijadikan miliki negara berhubung dengan pelaksanaan hak dan kewajiban tersebut. ${ }^{134}$ Dari definisi yuridis yang diterangkan oleh Undang-Undang Nomor 17 Tahun 2003 Tentang Keuangan Negara ini dapat ditinjau dari beberapa aspek. Pertama, definisi dan cakupan keuangan negara dalam arti yang luas, dan kedua pengertian keuangan negara dalam arti yang sempit.

Perumusan mengenai definisi keuangan negara didasarkan pendekatan yang digunakan. Kaitannya dengan definisi yang luas sebagaimana dijelaskan di dalam penjelasan Undang- Undang Keuangan Negara adalah sebagai berikut ${ }^{135}$;

1. Dari sisi obyek yang dimaksud keuangan negara meliputi semua hak dan kebijakan negara yang dapat dinilai dengan uang, termasuk kebijakan dan kegiatan dalam bidang fiscal, moneter dan pengelolaan kekayaan negara yang dipisahkan, serta segala sesuatu baik berupa uang maupun berupa barang yang dapat dijadikan milik negara berhubung dengan pelaksanaan hak dan kewajiban tersebut;

133 Lihat PP No 60 Tahun 2014 Tentang Dana Desa yang Bersumber Dari Anggaran Pendapatan Dan Belanja Negara

134 Lihat pasal 1 Undang-Undang No 17 Tahun 2003 Tentang Keuangan Negara

135 Lihat penjelasan Undang-Undang No. 17 Tahun 2003 Tentang Keuangan Negara 
2. Dari sisi subjek, yang dimaksud keuangan negara meliputi seluruh objek sebagaimana diatas yang dimiliki negara, dan/atau dikuasai oleh pemerintah pusat, pemerintah daerah, perusahaan negara/daerah, dan badan lain yang ada kaitannya dengan keuangan negara;

3. Dari sisi proses, keuangan negara mencakup seluruh rangkaian kegiatan yang berkaitan dengan pengelolaan objek sebagaimana di atas mulai dari perumusan kebijakan dan pengambilan keputusan sampai dengan pertanggungjawaban;

4. Dari sisi tujuan, keuangan negara meliputi seluruh kebijakan, kegiatan dan hubungan hukum yang berkaitan dengan pemilikan dan/ atau penguasaan objek sebagaimana di atas dalam rangka penyelenggaraan pemerintahan negara;

Dari penjelasan yang diberikan oleh Undang-Undang Nomor 17 Tahun 2003 dapat ditarik sebuah kesimpulan bahwa keuangan negara dalam arti luas adalah sesuatu yang tidak terpisahkan seperti: a) anggaran pendapatan dan belanja negara; b) anggaran pendapatan dan belanja daerah; c) keuangan negara pada Badan Usaha Milik Negara; dan d) Badan Usaha Milik Daerah. Sedangkan dalam artian sempit keuangan negara dimaknai sebagai anggaran pendapatan dan belanja negara yang ditetapkan dalam bentuk undang- undang. Artinya secara yuridis tidak dapat dipisahkan secara konsep antara keuangan negara dalam artian luas dan keuangan negara dalam artian yang sempit. Ruang lingkup keuangan negara sebagaimana di jelaskan di dalam Undang-Undang mengenai keuangan negara dapat dikategorikan sebagai berikut; 136

1. Hak negara untuk memungut pajak mengeluarkan dengan mengedarkan uang dan melakukan pinjaman; 
2. Kewajiban negara untuk menyelengggatakan tugas layanan umum pemerintahan negara dan membeyar tagihan pihak ketiga;

3. Penerimaan negara

4. Pengeluaran negara;

5. Penerimaan daerah;

6. Pengeluaran daerah

7. Kekayaan negara/kekayaan daerah yang dikelola sendiri atau oleh pihak lain berupa uang, surat berharga, piutang, barang, serta hak- hak lain yang dapat dinilai dengan uang, termasuk kekayaan yang pisahkan pada perusahaan negara/ perusahaan daerah;

8. Kekayaan pihak lain yang dikuasai oleh pemerintah dalam rangka penyelenggaraan tugas pemerintahan dan/atau kepentingan umum;

9. Kekayaan pihak lain yang diperoleh dengan menggunakan fasilitas yang akan diberikan oleh pemerintah.

Sedangkan dari sudut pengolaan keuanagn negara merupakan bagian dari pelaksanaan pemerintahan negara. Pengelolaan keuangan negara adalah keseluruhan kegiatan pejabat pengelola keuangan negara sesuai dengan keududkan dan kewenangannya, yang meliputi perencanaan, pelaksanaan, pengawasan, pertanggung jawaban, dan pemeriksaan keuangan negara. ${ }^{137}$ Berdasarkan konsep mengenai keuangan negara tersebut pantas maka dana desa secara otomatis masuk ke dalam sistem pengelolaan keuangan negara sebagaimana ketentuan peraturan perundang- undangan yang berlaku. Dalam hal ini pemerintah mengelokasikan dana Desa dalam APBN setiap tahun anggaran yang diperuntukkan bagi desa yang ditransfer melalui APBD Kabupaten/Kota. ${ }^{138}$ Dengan inilah pemerintah berharap agar pemerintahan desa dapat

137 Muhammad Djafar Saidi, Eka Merdekawati Djafar, Hukum Keuangan Negara Teori Dan Praktik, (Jakarta: Rajawali Press, 2017) hlm 17.

138 Lihat Pasal 95 PP No 43 Tahun 2014 
mengefektifkan program yang berbasis desa secara merata dan berkeadilan. 139

Dalam rangka pengalokasian dana desa tersebut dihitung berdasarkan jumlah desa dan dialokasikan dengan memperhatikan jumlah penduduk angka kemiskinan, luas wilayah, dan tingkat kesulitan geografis. ${ }^{140} \mathrm{Hal}$ ini lah yang kemudian membuat dana desa berbeda beda dari segi jumlah yang ditransfer oleh pemerintah kepada Pemerintah Daerah baik Kabupaten maupun Kota. Semakin miskin dan daerah sebuah desa tersebut semakin sulit secara geografis maka dana desa yang ditransfer pun bisa semakin banyak. Hal ini meupakan suatu langkah yang progresif dilakukan oleh pemerintah karena tidak setiap daerah memiliki potensi yang berbeda beda, maka dari segi penganggaran pun juga berbeda. Dengan adanya ketentuan pengaturan mengenai dana Desa beserta tata cara pengalokasiannya maka posisi dana desa sangat strategis dalam rangka pembangunan, pemberdayaan pemerintah dan masyarakat desa. Hal ini ditunjukkan dengan adanya data yang berasal dari Kementrian Keuanagan Republik Indonesia yang mencatat realisasi dana Desa sepanjang tahun 2015 dan 2016 sejak diundangkannya Undang-Undang Nomor 6 Tahun 2014 Tentang Desa.

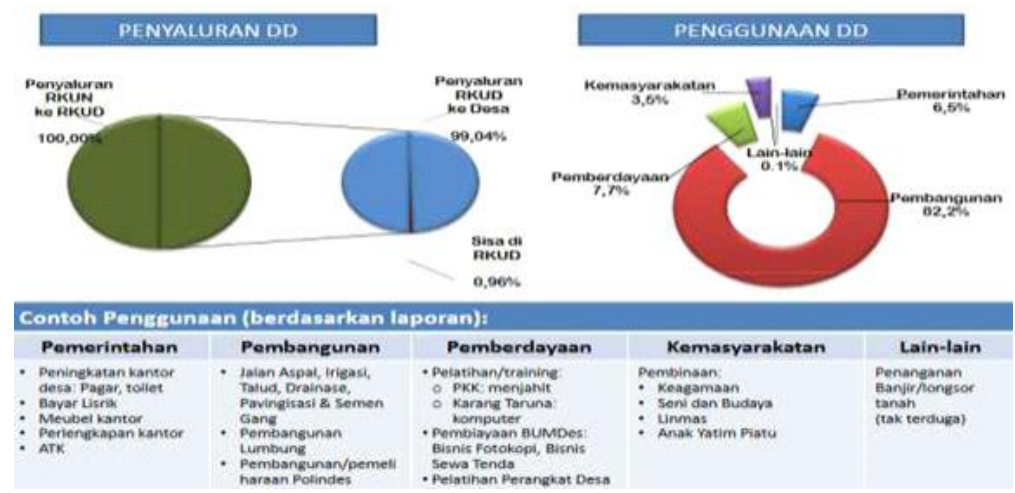

Gambar 1. Realisasi Dana Desa

139 Lihat Pasal 4 PP No 60 Tahun 2014 Tentang Dana Desa yang bersumber dari Anngaran Pendapatan dan Belanja Negara

${ }^{140}$ Lihat pasal 5 PP No 60 tahun 2014 

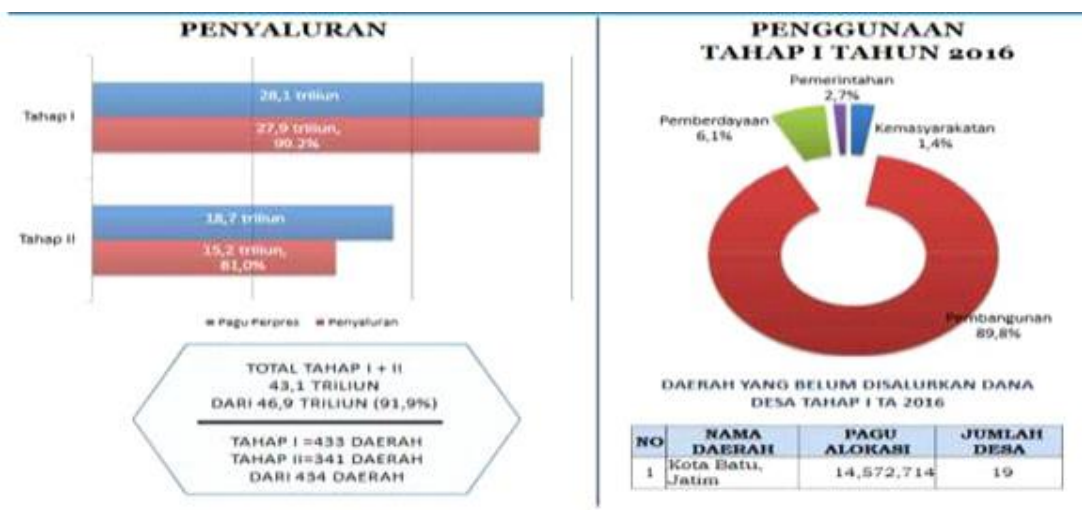

Gambar 2. Penyaluran dan Penggunaan Dana Desa ${ }^{141}$

\section{Politik Hukum Penataan Pengelolaan, Pertanggungjawaban dan Pengawasan Dana Desa}

Pasca diundangkan Undang-Undang Nomor 6 Tahun 2014 Tentang Desa, secara tidak langsung memberikan dampak positif bagi eksistensi peran pemerintah desa. Dalam hal ini desa dapat menjadi berdaya dengan adanya dana desa tersebut. besarnya dana desa dapat dijadikan sebagai modal dalam rangka pemberdayaan pemerintahan desa, masyarakat desa di berbagai sektor baik itu pendidikan, sosial ekonomi, maupun pengembangan budaya serta pariwisata yang menjadi potensi bagi desa. Namun ada beberapa hal yang bisa dijadikan catatan. Awal tahun 2014 lalu merupakan titik di mana gong pemberdayaan desa dibunyikaan seiring diundangkannya Undang-Undang tentang desa tersebut, lagi lagi di kala itu kepentingan politik menyambangi dunia hukum khususnya di bidang otonomi desa.

Isu mengenai pemberian alokasi dana desa kian di gembar gemborkan menjadi bahan kampanye baik itu secara personal maupun secara kelompok mewakili partai politik. Selain itu pasangan calon presiden dan wakil presiden turut menjanjikan akan menggelontorkan dana desa sejumlah $1 \mathrm{M}$

141 Siti Khoiriah, Utia Meylina,Analisis Sistem Pengelolaan Dana Desa Berdasarkan Regulasi Keuangan Desa, Jurnal Masalah- Masalah Hukum Fakultas Hukum Universitas Diponegoro, Jilid 46 No.1 Januari 2017, hlm 20-29 
untuk tiap- tiap desa di Indonesia, sedangkan di Indonesia sendiri terdapat 72.944 Desa. Artinya jika janji- janji politik ini terealisasi maka di dalam mata Anggaran Pendapatan dan Belanja Negara terdapat Rp 73 Triliyun untuk desa. ${ }^{142} \mathrm{Hal}$ ini tentu akan merubah pemerintahan desa secara tidak langsung. Upaya merubah desa menjadi basis otonomi akan terhambat jika tanpa diiringi dengan mekanisme pengawasan yang maksimal dan tanggung jawab perangkat desa, dapat menjadi bumerang yang justru dapat menghancurkan ikatan sosial warga/masyarakat desa. ${ }^{143}$ Sehingga di dalam pengelolaan dana desa tersebut perlu adanya pertangungjawaban serta pengawasan dalam pengalokasian dana desa tersebut.

\section{Pengelolaan Dana Desa}

Sebagaimana telah disinggung sebalumnya bahwa dalam Dana Desa tersebut bersumber dari APBN yang kemudian ditransfer malalui Rekenung Umum Kas Daerah (RKUD) selanjutnya akan langsung ditransfer ke Rekening Kas Desa. Dalam pelaksanaanya pengalokasian dana desa akan dihitung dengan memperhatikan jumlah penduduk, angka kemiskinan, luas wilayah dan tingkat kesulitan geografis yang terletak di desa tersebut. ${ }^{144}$ Dengan adanya ketentuan tersebut dapat dipastikan setiap desa berbedabeda akan tetapi di dalam prinsip pengalokasian dana desa memiliki tujuan yang sama yakni digunakan untuk penyelenggaraan pemerintahan, pembangunan, pemberdayaan masyarakat, dan kemasyarakatan.

Dalam mekanisme pencairan dana desa tersebut dilakukan secara bertahap. Tahap pertama dilakukan pada bulan April dengan ketentuan 40\% (empat puluh persen). Tahap kedua dilaksanakan pada bulan Agustus sebesar 40\% dan yang terakhir di Bulan November dengan besaran dana sebanyak $20 \%$. Supaya lebih mudah memahami mengenai

142 Nimatul Huda, op.cit, hlm 228

143 Ibid.

144 Lihat pasal 11 PP No 22 Tahun 2015 Tentang Perubahan atas PP No 60 tahun 2014 Tentang Dana Desa yang Berasal Dari APBN. 
mekanisme penyaluran dana desa dapat dilihat dengan tabel berikut; ${ }^{145}$

\begin{tabular}{|c|c|}
\hline $\begin{array}{c}\text { Kementrian } \\
\text { Keuangan Negara } \\
\text { (Rekening Kas } \\
\text { Umum Negara ) } \\
\text { Rp } 20 \text { Triluyun }\end{array}$ & $\begin{array}{c}\text { Tahapan: } \\
\text { Pertama- 40\% April } \\
\text { Kedua- } 40 \% \text { Agustus } \\
\text { Ketiga 20\% November }\end{array}$ \\
\hline $\begin{array}{c}\text { Pemerintah } \\
\text { Kabupaten/Kota } \\
\text { (Rekening Kas } \\
\text { Umum Daerah) } \\
508 \\
\text { Kabupaten/kota }\end{array}$ & $\begin{array}{c}\text { Persayaratan: } \\
\text { - } \quad \text { RKUN ditransfer ke } \\
\text { RKUD dengan syarat } \\
\text { adanya peraturan } \\
\text { bupati/walikota } \\
\text { tentang tata cara dan } \\
\text { adanya pengesahan } \\
\text { APBD } \\
\text { - Desa mendapat } \\
\text { pencairan setelah } \\
\text { memiliki Rencana } \\
\text { Pembangunan Jangka } \\
\text { Menengah (RPJM) } \\
\text { dan Rencana Kerja } \\
\text { Pemerintah Desa }\end{array}$ \\
\hline $\begin{array}{l}\text { Desa/Kas Desa } \\
74.000 \text { Desa } \\
\text { Rata -rata per } \\
\text { Desa } \\
\text { Rp 240s/d } 270 \\
\text { Juta }\end{array}$ & $\begin{array}{l}\text { Formula menghitung ADD } \\
\text { - Jumlah Penduduk } \\
\text { desa } \\
\text { - Luas wilayah desa } \\
\text { - Angka kemiskinan } \\
\text { desa } \\
\text { - Tingkat kesulitan } \\
\text { geografis desa } \\
\text { Penggunaan } \\
\text { - Penyelenggaraan } \\
\text { Pemerintahan, }\end{array}$ \\
\hline
\end{tabular}

145 Republika 15 Januari 2015, dikutip oleh Nimatul Huda, op.cit, hlm 232 


\begin{tabular}{|l|l|}
\hline & pembangunan, \\
pemberdayaan & \\
masyarakat dan \\
kemasyarakatan \\
Prioritas untuk \\
pembangunan dan \\
pemberdayaan \\
masyarakat
\end{tabular}

Tabel 1 Penyaluran Dana Desa.

Karena Dana Desa bersumber dari keuangan negara maka secara tidak langsung dalam pengelolaan dana desa tersebut ikut tunduk terhadap asas- asas hukum sebaimana yang ditentukan oleh Undang Undang yakni: ${ }^{146}$

a. Asas akuntabilitas yang berorientasi pada hasil adalah asas yang menentukan bahwa setiap kegiatan dan hasil akhir dari kegiatan pengelolaan keuangan negara harus dapat dipertanggung jawabkan kepada rakyat sebagai pemegang kedaulatan tertinggi negara sesuai dengan peraturan perundang- undangan yang berlaku;

b. Asas profesionalitas adalah asas yang mengutamakan keseimbangan antara hak dan kewajiban pengelola keuangan negara;

c. Asas proporsionalitas adalah asas yang mengutamakan keahlian berdasarkan kode etik dan ketentuan peraturan perundang- undangan yang berlaku;

d. Asas keterbukaan dan pengelolaan keuangan negara adalah asas membuka diri terhadaphak masyarakat untuk memperoleh informasi yang benar jujur, tidak diskriminatif tentang persoalan keuangan negara dengan tetap memperhatikan perlindungan atas hak asasi pribadi, golongan, dan rahasia negara;

146 Lihat Penjelasan Undang-Undang No 17 Tahun 2003 Tentang Keuangan Negara, dikutip oleh Muhammad Djafar Saidi, Eka Merdekawati Djafar, Hukum Keuangan Negara Teori Dan Praktik, (Jakarta: Rajawali Press, 2017) hlm 18 
e. Asas pemerikasaan keuangan oleh badan pemeriksa yang bebas mandiri adalah asas yang memberikan kebebasan bagi Badan Pemeriksa Keuangan untuk melakukan pemeriksaan keuangan dengan tidak dipengaruhi oleh siapapun.

Cukup berat jika dana desa diterapkan asas sebagaimana pengelolaan keuangan negara, akan tetapi setidak-tidaknya dalam rangka mencapai tujuan ini masyarakat beserta pemerintah desa diharapkan mampu melakukan pengelolaan dana desa tersebut dengan alokasi anggran yang lebih akuntabilitas. Maka dalam pelaksanaannya pemerintah daerah turut serta di dalam pengelolaan dana desa sekalipun dana tersebut hanya mampir di Rekening Kas Umum Daerah. Dalam upaya pembangunan desa daerah pun juga turut andil di dalam pengalokasian dana desa sebagai pendapatan desa. Pemerintah Kabupaten/Kota mengalokasikan kepada desa paling sedikit 10\%(sepuluh perseratus) dari realisasi penerimaan hasil pajak dan retribusi daerah kabupaten/kota.

\section{Pertanggungjawaban dan pengawasan Dana Desa}

Kaitannya dengan pertanggungjawaban dana desa kepala desa bertanggung jawab untuk menyampaikan realisasi penggunaan Dana Desa kepada bupati/walikota. Kemudian Bupati/ Walikota menyampaikan realisasi penyaluran dan konsolidasi penggunaan Dana Desa kepada Menteri dengan tembusan kepada gubernur. ${ }^{147}$ Kementrian yang berwenang menerima laporan realisasi dana desa adalah menteri yang menyelenggarakan urusan pemerintahan di bidang pembangunan dan pemberdayaan masyarakat desa. Adanya alur pertanggungjawaban dari desa hingga pusat ini didasari bahwa sistem keuangan desa

147 Lihat Pasal 24 PP No 8 Tahun 2016 Tentang Perubahan kedua PP No 60 Tahun 2014 Tentand Dana Desa Yang Bersumber dari APBN 
merupakan hierarki struktur keuangan sentral dari pemerintah di atasnya.Kabupaten/Kota, Provinsi, bahkan Pemerintah Pusat mempunyai andil besar dalam pengalokasian sumber keuangan desa ini. ${ }^{148}$

Sedangkan di dalam hal pengawasan dana desa setidaknya ada beberapa argumentasi yang dapat disandingkan dengan aspek yuridis pengawasan mengai dana desa. Dana desa adalah bagian dari keuangan negara artinya dalam pengawasannya dibutuhkan sistem yang memadai di dalam mengawal keuangan negara tersebut. dalam hal pengawasan keuangan negara terdapat unsurunsur yang dapat dijadikan sebagai barometer dalam melakukan pengawasan terhadap dana desa. Di antaranya: ${ }^{149}$

a. Adanya kewenangan yang jelas yang dimiliki oleh aparat pengawas;

b. Adanya suatu perencanaan yang mantap sebagai alat penguji terhadap pelaksanaan suatu tugas yang diawasi;

c. Tindakan pengawasan dapat dilakukan terhadap suatu proses terhadap kegiatan yang sedang berjalan maupun terhadap hasil yang dicapai dari kegiatan tersebut;

d. Tindakan pengawasan berakhir saat evaluasi akhir terhadap kegiatan yang dilaksanakan serta pencocokan hasil yang dicapai dengan rencana sebagai tolok ukurnya;

e. Untuk selanjutnya tindakan pengawasan akan diteruskan dengan tindak lanjut baik secara administrasif maupun secara yuridis.

Kategori tersebut merupakan barometer yang dilakukan ketika dana desa dimasukkan ke dalam alokasi dana desa yang diperuntukkan dengan beragam program

148 Sumbu, Telly (2010) Hubungan PemerintahPusat dengan Pemerintah Daerah dalam Ke r a n g k a P e n g e l o l a a $n$ Keuangan Negara dan Daerah, Jurnal Hukum No. 4 Vol. 17 Oktober.

149 W Riawan Tjandra, Hukum Keuangan Negara, (Jakarta: Grasindo,2014) hlm 225. 
sebagaimana garis besar program program yangv telah ditentukan secara yuridis menurut peraturan perundang-undangan yang berlaku.

Pengawasan dana desa ini dapat ditempuh dengan beberapa jalur salah satunya dengan pengawasan secara internal kelembagaan (internal control) dan pengawasan secara eksternal (external control). ${ }^{150}$ Pertama pengawasan secara internal kelembagaan, pengawasan ini dilakukan oleh suatu lembaga/badan/organ yang secara structural masih termasuk organisasi dalam lingkungan pemerintah, missal: pengawasan dana desa yang dilakukan oleh pejabat atasan terhadap bawahan seperti pengawasan yang dilakukan oleh Bupati/ Walikota kepada Kepala Desa dalam pelaksanaan program yang anggrannya berasal dari dana desa.

Kedua pengawasn eksternal, pengawasan ini dilakukan oleh badan/organ yang dilakukan di luar pemerintah dalam artian lembaga eksekutif. Dalam hal ini yang paling dekat dengan kepala desa adalah Badan Permusyawaratan Desa (BPD) sebagai lembaga legislatif yang duduk di wilayah pemerintahan Desa sebagai implementasi dari perwakilan masyarakat desa. Selain itu kaitannya dengan dana desa masyarakat desa juga dapat langsung mengawasi dari pengelolaan alokasi dana desa tersebut. BPK sebagai lembaga audit keuangan negara juga dapat mengawasi aliran dana desa ini karena dana desa adalah bagian dari keuangan negara.

\section{Analisis Politik Hukum Pengelolaan, Pertanggung jawaban dan Pengawasan Dana Desa}

Memahami persoalan dana desa tersebut tentu tidak bisa dipahami secara parsial. Artinya kebijakan dana desa ini bersinggungan dengan sistem keuangan negara sebagaimana dijelaskan dalam pembahasanan sebelumnya, selain itu pemerintah daerah juga memiliki andil dalam pendistribusian dana desa tersebut. Oleh karena kebijakan

150 W. Riawan Tjandra, op cit., hlm 226 
dana desa bersinggungan dengan berbagai hal tersebut, maka relevan jika melihat persoalan inidari kacamata politik hukum. Politik hukum dalam konteks yang umum dimaknai dengan legal policy yang akan atau telah dilaksanakan secara nasional oleh Pemerintah Indonesia yang meliputi: Pertama, pembangunan hukum yang berintikan pembuatan dan pembaruan terhadap materi materi hukum yang berintikan pembuatan dan pembaharuan materi hukum agar dapat sesuai dengan kebutuhan; kedua, pelaksanaan ketentuan hukum yang telaah ada termasuk penegasan fungsi lembaga dan pembinaan penegak hukum. ${ }^{151}$ Kedua makna ini jika diperas maka mengerucut pada blue print atau cetak biru dari arah pembangunan hukum dan penataan lembaga beserta aparatur lembaga tersebut. Dalam konteks dana desa jika dikaitkan dengan kerangka politik hukum maka terdapat setidaknya ada tiga hal meliputi: Pertama politik hukum yang berkaitan dengan materi pembentukan pemerintah desa berikut dana desa sebagai salah satu sumber pembiayaan pemerintahan, kedua pelaksanaan pengelolaan dana desa sebagaimana yang telah dijelaskan di dalam pembahasan sebelumnya, ketiga penegasan peran dan fungsi masing masing lembaga yang memiliki kewenangan dalam melakukan pengelolaan, pertanggungjawaban dan pengawasan dana desa.

Berdasarkan sejarah politik hukum pemerintahan desa dan otonomi desa setidaknya terdapat tujuh kali perubahan undang- undang yang mengatur tentang pemerintahan desa yaitu: Pertama, Pertama, Pengaturan pemerintahan desa di dalam Undang-Undang No. 22 Tahun 1948 Tentang Pokok- Pokok Pemerintahan Daerah, desa digolongkan sebagai pemerintah daerah tingkat III. Dalam penjelasaan umum Undang-Undang No. 22 Tahun 1948 menegaskan alasan mengenai pengaturan desa sebagai

151 Moh Mahfud MD, Politik Hukum di Indonesia , (Jakarta: Raja Grafindo Persada,2012), hlm 17 
daerah tingkat tiga. Ini disebabkan karena daerah otonom terbawah adalah desa, negeri, kota kecil dan sebagainya. Artinya dengan pengaturan yang demikian desa diletakkan ke dalam lingkungan pemerintahan yang modern, padahal sejatinya desa memiliki aspek historis yang sangat kuat. Kondisi demikian saat itu dipahami oleh pemerintahan kolonial, bahwa desa adalah sendi negara, maka dari itu haruslah diperbaiki dari segala aspek, diperkuat dan didinamisir supaya dapat mengalami kemajuan. Dalam pasal 18 ayat (3) Undang-Undang No. 22 Tahun 1948 menjelaskan bahwa "Kepala daerah Desa (kota kecil) diangkat oleh Kepala Daerah dari sedikit-sedikitnya dua dan sebanyak-banyaknya empat orang calon yang diajukan oleh Dewan Perwakilan Rakyat Daerah Desa (kota kecil)." Dengan adanya ketentuan pasal ini secara tidak langsung medelegitimasi terhadap eksistensi demokrasi yang ada di dalam wilayah desa. Sehingga terkesan adanya intevensi dari pemerintah daerah diatasnya dalam pemilihan kepala desa atau daerah yang semacamnya. Kedua, pengaturan desa dalam Undang-Undang No. 18 Tahun 1965 tentang PokokPokok Pemerintahan Daerah. Ketentuan umum dalam undang- undang ini menegaskan yang dimaksud dengan desa atau daerah setingkat dengan itu adalah kesatuan masyarakat hukum ${ }^{152}$ desan kesatuan penguasa yang berhak mengatur dan mengurus rumah tangganya sendiri sebagaimana yang dijelaskan di dalam penjelasan pasal 18 Undang-UndangD 1945. Ketiga, Pemerintahan desa menurut Undang-Undang No. 19 Tahun 1965 Tentang Desa praja. Dalam pasal 3 Undang-Undang No. 19 Tahun 1965 menegaskan bahwa Desapraja adalah badan hukum. Artinya setiap tindakan yang dilakukan oleh Desapraja dapat dinilai wewenangnya. ${ }^{153}$ Sehingga Desapraja bisa

152 Penjelasan mengenai masyarakat hukum telah dijelaskan di dalam sub bab yang sama salahsatunya yang memberikan penjelasan adalah Bagir Manan.

153 Secara teoritik dalam Hukum Administrasi Negara dikenal dengan legaliteitdbeginsel atau het beginsel van wetmatigheid van bestuur, berdasarkan prinsip 
menghadap di muka pengadilan dengan diwakili oleh Kepala Desapraja. Sedangkan makna mengenai Desa dalam undang- undang ini adalah kesatuan masyarakat hukum yang tertentu batas- batas daerahnya, berhal mengurus rumah tangganya sendiri, memilih penguasanya dan mempunyai harta benda sendiri. ${ }^{154}$ Jika diruntut , Undang-Undang ini lahir pasca adanya dektrit Presiden tahun 1959 sehingga spirit yang diusung oleh Undang-Undang ini adalah terciptanya manifestasi dari demokrasi terpimpin. Hal ini ditunjukkan dengan adanya beberapa indikator diantaranya: Pertama, Undang-Undang ini adalah bentuk penjabaran dari Pasal 18 Undang-UndangD 1945. Ini berarti bahwa kesatuan masyarakat hukum harus mendapat tempat dalam rangka Pemerintahan Daerah. Oleh karena kesatuankesatuan masyarakat hukum itu mempunyai pula hak mengurus rumah tangganya sendiri sebagai konsekuensi kesejarahan yang tumbuh berkembang, padahal di bawah daerah tingkat II hanya aka nada daerah administrasi belaka, maka dengan demikian posisi masyarakat hukum tersebut secara langsung dapat ditingkatkan menjadi daerah tingkat III, sehingga pada akhirnya daerah tingkat III inilah yang menggantikan masyarakat- masyarakat hukum yang ada sesuai dengan pedoman pelaksanaan Ketetapan MPRS No./MPRS/1960 Tengang Garis- Garis Besar Pola Pembangunan Nasional Semesta Berencana Tahapan Pertama 1961-1966. Kedua, dalam pasal 8 Undang-Undang No. 19 Tahun 1965 disebutkan secara tegas bahwa "Kepala Desapraja adalah penyelenggara utama urusan rumah-tangga Desapraja dan sebagai alat Pemerintah pusat." Karena sifatnya sebagai alat Pemerintah pusat sudah dapat dipastikan beberapa intervensi yang dilakukan oleh Pemerintah pusat dapat dilakukan mengenai Kepala Desapraja. Ketiga, tidak

tersirat bahwa wewenang pemerintahan berasal dari peraturan perundangundangan. Dalam Ridwan HR, Op.Cit, hlm 91

${ }_{154}$ Pasal 1 Undang-Undang No. 19 Tahun 1965. 
adanya sistem pengawasan yang dilakukan oleh Badan Musyawarah Desapraja kepada Pemerintah Desapraja. Dengan demikian lengkap sudah bahwa Badan Musywarah Desapraja hanya sebagai pelengkap saja, ibarat kata hidup segan mati pun tak mau.

Keempat, pemerintahan desa dalam Undang-Undang Nomor 5 Tahun 1974 Tentang Pemerintahan Daerah dan Undang-Undang Nomor 5 Tahun 1979 Tentang Desa, dalam undang-undang ini secara eksplisit memang tidak mengatur mengenai pemerintahan desa hanya pasal 88 dalam undang-undang ini menyebutkan pengaturan tentang Pemerintahan Desa ditetapkan dalam undang-undang. Sebagai implikasi dari adanya ketentuan pasal 88 ini maka setelahnya lahir Undang-Undang Nomor 5 Tahun 1979 Tentang Pemerintahan Desa. Undang-Undang ini dapat dikatakan sebagai pengaturan pertama mengenai pemerintahan desa yang diatur secara tersendiri. Dari Undang-Undang ini Pemerintah bersama dengan DPR mencoba merekonstruksi maka desa, sehingga bermakna bahwa

"Desa adalah suatu wilayah yang ditempati oleh sejumlah penduduk sebagai kesatuan masyarakat termasuk di dalamnya kesatuan masyarakat hukum yang mempunyai organisasi pemerintahan terendah langsung di bawah Camat dan berhak menyelenggarakan rumah tangganya sendiri dalam ikatan Negara Kesatuan Republik Indonesia."155

Dalam pemaknaan norma ini terkandung bahwa desa berada di bawah camat yang merupakan representasi dari Pemerintah Daerah. Kaitanya dengan ini, Pimpinan Pemerintahan Desa pun memiliki hubungan pertanggungjawaban dengan pejabat yang berwenang mengangkat melalui camat. ${ }^{156}$ Dalam undang-undang ini

155 Lihat Pasal 1 huruf (a) Undang-Undang No.5 Tahun 1979 Tentang Desa.

156 Lihat Pasal 10 Undang-Undang No. 5 Tahun 1979 
mengarahkan pada penyeragaman bentuk dan susunan pemerintah desa dengan corak nasional yang diharapkan mampu mewujudkan visi Demokrasi Pancasila secara nyata dengan menyalurkan aspirasi masyarakat dalam wadah yang disebut Lembaga Musyawarah Desa (LMD). Oleh karenanya di dalam Undang-Undang ini tidak mengakui adanya nagari, huta, sosor, marga, binua, lembang, parangiu dan lain- lain yang umumnya berada di luar pulau jawa.

Kelima, paca tumbangnya orde baru digantikan dengan reformasi keberadaan pemerintahan desa diatur dengan Undang-Undang Nomor 22 Tahun 1999 tentang Pemerintahan Daerah. Spirit yang diusung dalam undangundang ini adalah menegaskan pengakuan terhadap keragaman dan keunikan desa (atau dengan nama lain) sebagai self government community yang termanifestasi dalam frasa Istimewa dalam pasal 18 UUD 1945. Pemaknaan ini jelas berbeda dengan undang- undang sebelumnya (Undang-Undang Nomor 5 Tahun 1979) yang menempatkan desa unit pemerintahan paling rendah di bawah camat. Dalam undang-undang ini dijelaskan mengenai definisi pemerintahan desa yaitu: “Desa atau yang disebut dengan nama lain, selanjutnya disebut desa, adalah kesatuan masyarakat hukum yang memiliki kewenangan untuk mengatur dan mengurus kepentingan masyarakat setempat berdasarkan asal usul dan berada di daerah kabupaten. Dengan adanya payung hukum ini kini desa dapat membuat regulasi desa sendiri untuk mengatur dan mengurus kepentingan masyarakat setempat sesuai dengan hak asal-usul desa. Selain iti desa juga berhak mengelola aset desa melalui peraturan desa. Selain itu desa juga berhak mengelola aset desa melalui peraturan desa. Selain itu pemerintahan desa dalam Undang-Undang Nomor 22 Tahun 1999 didukung dengan Badan Perwakilan Desa. Istilah penyebutan ini dapat disesuaikan dengan kondisi masing- masing masyarakat. Anggota BPD ini dipilih oleh rakyat dari dan oleh penduduk yang memenuhi 
persyaratan. ${ }^{157}$ Fungsi dari BPD tersebut sebagai pengawas jalannya pemerintahan.

Keenam, pengaturan desa di dalam Undang-Undang No. 32 Tahun 2004, dalam pengaturan undang- undang ini posisi mengenai pemerintahan desa tidak mengalami perubahan secara substansial, hanya terjadi perubahan perubahan yang bersifat teknis saja diantaranya: 158

a. Desa dirumuskan sebagai kesatuan masyarakat hukum yang memiiki batas- batas wilayah yang berwenang untuk mengatur dan mengurus kepentingan masyarakat setempat, berdasarkan asal-usul dan adat istiadat masyarakat setempat yang diakui dan dihormati dalam system pemerintahan NKRI;

b. Desa yang semula ditentukan hanya ada di daerah kabupaten, kemudian juga bias ada di wilayah perkotaan;

c. Badan Perwakilan Desa diubah menjadi Badan Permusyawratan Desa;

d. Desa boleh membuat lembaga yang bias memberikan keuntungan material/ financial yang merupakan badan usaha miliki desa;

e. Masa jabatan kepala desa dan bdan perwakilan desa yang semula sama- sama lima tahun diubah menjadi enam tahun.

Ketujuh, pemerintahan desa di dalam UndangUndang Nomor 6 Tahun 2014. Undang undang ini disusun guna melakukan revisi terhadap beberapa pasal yang mengatur mengenai Pemerintahan Desa di dalam undangundang sebelumnya (Undang-Undang Nomor 32 Tahun 2004). Melalui undang- undang ini (Undang-Undang Nomor 6 Tahun 2014 Tentang Pemerintahan Desa), Negara berusaha untuk melindungi dan memberdayakan desa agar menjadi kuat, maju, mandiri, dan demokratis sehingga

157 Lihat Pasal 105 Undang-Undang No. 22 Tahun 1999

158 Mashuri Maschab, Politik Pemerintahan.

, Op. Cit, hlm 146-147 
dapat menciptakan landasan yang kuat dalam melaksanakan pemerintahan dan pembangunan menuju masyarakat yang adil, makmur dan sejahtera. Untuk menopang itu maka di dalam pasal 72 Undang-Undang tersebut mengamanatkan adanya dana desa. Dalam peraturan yang lebih teknis pengaturan dana desa terdapat pada:

a. Peraturan Pemerintah Nomor 43 Tahun 2014 Tentang Peraturan Pelaksanaan Undang-Undang Nomor 6 Tahun 2014 Tentang Desa.

b. Peraturan Pemerintah Nomor 47 Tahun 2015 Tentang Perubahan Atas PP Nomor 43 Tahun 2014 Tentang Peraturan Pelaksanaan Undang-Undang Nomor 6 Tahun 2014 Tentang Desa;

c. Peraturan Pemerintah Nomor 60 Tahun 2014 Tentang Dana Desa Yang Bersumber Dari APBN;

d. Peraturan Pemerintah Nomor 22 Tahun 2015 Tantang Perubahan Atas PP Nomor 60 Tahun 2014 Tentang Dana Desa Yang Bersumber Dari APBN;

e. Peraturan Pemerintah Nomor 8 Tahun 2016 Tentang Perubahan Kedua Atas PP Nomor 60 Tahun 2014;

f. Peraturan Menteri Keuangan No. 247 Tahun 2015 Tentang Tata Cara Pengalokasian, Penyaluran, Penggunaan, Pemantauan, Dan Evaluasi Dana Desa;

g. Peraturan Menteri Keuangan No. 49 Tahun 2016 Tentang Tata Cara Pengalokasian, Penyaluran, Penggunaan, Pemantauan, Dan Evaluasi Dana Desa;

h. Peraturan Menteri Dalam Negeri Nomor 113 Tahun 2014 Tentang Pengelolaan Keuangan Desa;

i. Peraturan Menteri Desa, Pembangunan Daerah Tertinggal, Dan Transmigrasi Nomor 21 Tahun 2015 Tentang Penetapan Prioritas Penggunaan Dana Desa Tahun 2016.

Berdasarkan sembilan peraturan ini, ditambah lagi dengan peraturan teknis dari pemerintah daerah setempat 
tentunya menambah panjang deretan peraturan teknis mengenai dana desa. Dengan demikian, kepala desa dan jajarannya beserta setidaknya harus memahami beragam regulasi teknis yang mengatur tentang pengelolaan dana desa. Banyaknya regulasi yang mengatur tentang dana desa, tidak menutup kemungkinan terjadi tumpang tindih antara satu peraturan dengan peraturan yang lainnya. Sebagai contoh, dalam tahapan pelaporan dana desa, dalam Peraturan Menteri Dalam Negeri Nomor 20 tahun 2018 laporan dana desa dilakukan secara berjenjang. Kemudian disisi lain desa juga dibebankan laporan pertanggungjawaban prioritas penggunaan dana desa yang didasarkan pada Pemerndes PDTT No 16 tahun 2018 tentang prioritas penggunaan dana desa. Akibatnya terjdi redundasi laporan realisasi dana desa meskipun dengan nama yang berbeda akan tetapi sama secara prinsip. Kemudian fungsi kelambagaan pengawasan Badan Permusyawaratan Desa juga memiliki kewenangan guna melakukan pengawasan, akan tetapi pengawasan yang dilakukan oleh Badan Permusyawaratan Desa hanya sebatas memberikan informasi saja tidak sampai melakukan upaya korektif terhadap pengelolaan dan penggunaan dana desa. ${ }^{159}$ Oleh karena itu maka politik hukum yang dicapai dalam aspek pengelolaan, pertanggungjawaban setidaknya mengerucut pada dua hal: Pertama, penataan peraturan perundang-undangan yang berkaitan dengan dana desa. Pada dasarnya ini adalah masalah klasik yang harus dipecahkan mengingat tidak semua perangkat desa dan jajarannya memiliki kapasitas yang sama dalam memahami regulasi atau peraturan perundang- undangan. Kedua, penguatan tugas dan wewenang Badan Permusyawaratan Desa atau yang disebut dengan mana lain dalam hal pengawasan pelaksanaan program yang didanai oleh Dana Desa. Badan Permusyawaratan Desa seharusnya memiliki

159 Rheza Firmansyah (2019) Pengelolaan dan Pertanggungjawaban Dana Desa di Kecamatan Kasihan, Tesis Magister Ilmu Hukum FH UII 
wewenang melakukan koreksi dan perbaikan apabila ditemukan kesalahan dalam penggunaan dan pengelolaan Dana Desa, dengan demikian mekanisme cheks and balances dapat berjalan dengan maksimal.

\section{Penutup}

Berlakunya Undang-Undang No.6 Tahun 2014 Tentang Desa merupakan lompatan yang sangat progresif di bidang otonomi desa. Pengakuan yang bisa dianggap setengah-setengah oleh pemerintah pusat terhadap pemerintah desa kini semakin menjadi utuh pengakuan sepenuhnya bahwa desa adalah otonomi asli dari bentuk Negara Kesatuan Republik Indonesia (NKRI). Pengakuan itu tidak cukup dengan diberikannya Undang-Undang yang membahas khusus tentang Desa, akan tetapi diberikannya dana desa marupakan sebuah bentuk nyata bahwa pembuat Undang- Undang dan pemerintah ingin desa bisa lebih berkembang dan maju. Dengan adanya Dana Desa secara otomatis merubah wajah Pemerintahan Desa menjadi basis otonomi yang kuat. Regulasi mengenai pengalokasian dana desa pun dibuat dengan sedemikian rapinya sehingga benar benar mencerminkan bahwa Indonesia adalah Negara Kesatuan yang peduli akan wilayah- wilayahnya. Namun perlu manjadi catatan besaran dana desa yang digelontorkan dari APBN sebanyak 73 triliyun menjadi rawan penyalahgunaan yang berujung pada tindak pidana korupsi. Oleh karena itu perlu adanya politik hukum untuk melindungi perangkat desa dan jajarannya agar tidak sampai terjerumus pada tindak pidana tersebut. Politik hukum yang dapat diupayakan adalah: Pertama, dalam melakukan penetapan dan penggunaan Dana Desa sebagaimana telah dilakukan dengan musyawarah desa hendaknya secara konsisten dilakukan supaya dalam penetapannya terhindar dari kesalahan baik secara administratif maupun kesalahan lain. Selain itu dengan adanya forum musywarah desa ini dapat membantu kinerja pemerintah desa khusnya dalam melaksanakan program/ kegiatan yang didanai oleh Dana 
Desa agar tepat sasaran dan terselenggara secara efektif dan efisien. Kedua, Pentingnya penguatan tugas dan wewenang Badan Permusyawaratan Desa atau yang disebut dengan mana lain dalam hal pengawasan pelaksanaan program yang didanai oleh Dana Desa. Badan Permusyawaratan Desa seharusnya memiliki wewenang melakukan koreksi dan perbaikan apabila ditemukan kesalahan dalam penggunaan dan pengelolaan Dana Desa, dengan demikian mekanisme cheks and balances dapat berjalan dengan maksimal. Ketiga, sinkronisasi (harmonisasi) regulasi yang mengatur tentang dana desa agar tidak terjadi tumpangtindih antara satu regulasi dengan regulasi yang lain. 


\section{Daftar Pustaka}

\section{Buku}

Huda,Ni'matul Hukum Pemerintahan Desa,Malang: Setara Press 2015

Manan, Bagir, Menyongsong Fajar Otonomi Daerah ,Yogyakarta: Pusat Studi Hukum Fakultas Hukum Universitas Islam Indonesia, 2001.

Moh Mahfud MD, Politik Hukum di Indonesia, Jakarta: Raja Grafindo Persada,2012

Nawawi, Hidari, Metode Penelitian Bidang Sosial, cet . ke- 13, Yogyakarta: Gadjah Mada University Press, 2012

Saidi,Muhammad Djafar, Eka Merdekawati Djafar, Hukum Keuangan Negara Teori Dan Praktik, Jakarta: Rajawali Press, 2017.

Sugiyono, Metode Penelitian Pendidikan Pendekatan Kuantitatif, Kualitatif,dan RED, cet. Ke 19,Bandung: Alfabeta, 2014,

Tjandra,W Riawan, Hukum Keuangan Negara, Jakarta: Grasindo,2014.

\section{Jurnal}

Siti Khoiriah, Utia Meylina,Analisis Sistem Pengelolaan Dana Desa Berdasarkan Regulasi Keuangan Desa, Jurnal Masalah- Masalah Hukum Fakultas Hukum Universitas Diponegoro, Jilid 46 No.1 Januari 2017.

Sumbu, Telly (2010) Hubungan PemerintahPusat dengan Pemerintah Daerah dalam Ke ra $n$ g a P e n g e lo l a a n Keuangan Negara dan Daerah, Jurnal Hukum No. 4 Vol. 17 Oktober. 


\section{Peraturan Perundang- Undangan}

Undang- Undang Dasar Negara Republik Indonesia Tahun 1945

Undang- Undang No. 17 Tahun 2003 Tentang Keuangan Negara

Undang- Undang No. 6 Tahun 2014 Tentang Desa

Peraturan Pemerintah No. 43 Tahun 2014 tentang Pelaksanaan Undang- Undang No. 6 Tahun 2014

Peraturan Pemerintah No. 60 Tahun 2014 Tentang Dana Desa Bersumber dari Anggran Pendapatan dan Belanja Negara

Peraturan Pemerintah No. 22 Tahun 2015 Perubatan Atas Peraturan Pemerintah No. 60 Tahun 2014 Tentang Dana Desa Bersumber dari Anggran Pendapatan dan Belanja Negara

Peraturan Pemerintah No. 8 Tahun 2016 Perubatan Kedua Atas Peraturan Pemerintah No. 60 Tahun 2014 Tentang Dana Desa Bersumber dari Anggran Pendapatan dan Belanja Negara

\section{Lain- Lain}

Harian Kompas 29 November 2014

Harian Republika 15 Januari 2015. 


\section{POLITIK HUKUM PENGATURAN PENERTIBAN DAN PENDAYAGUNAAN TANAH TERLANTAR DI INDONESIA}

\section{Satria Sukananda}

Kepala Subseksi Pendaftaran Hak Tanah Kementerian Agraria dan Tata Ruang/Badan Pertanahan Nasional, Kantor Pertanahan

Kabupaten Lingga

Email: Satria.sukananda@atrbpn.go.id

\section{A. Pendahuluan}

Tanah adalah karunia Tuhan Yang Maha Esa yang merupakan salah satu unsur dalam segala aktivitas kehidupan manusia. Semua aktivitas kehidupan manusia di dunia ini memerlukan tanah. Sebagai sumber daya alam, tanah memiliki nilai ekonomi sehingga kebijakan pertanahan haruslah merupakan bagian yang tidak terpisahkan (integral) dari kebijakan pembangunan nasional. ${ }^{160}$

Permintaan akan tanah semakin besar akibat meningkatnya pembangunan dan bertambahnya jumlah penduduk. Sebaran penduduk yang tidak merata, sedangkan luas tanah relatif tetap, secara akumulatif telah mengakibatkan permasalahan tanah semakin kompleks. Untuk dapat dimanfaatkan sesuai potensi maksimalnya, tanah harus dikelola secara terencana, terkoordinasi, dan terpadu. ${ }^{161}$

Keniscayaan dan kebutuhan memiliki tanah sudah tertanam sedemikian mendalam dalam lintasan sejarah

160 Petunjuk Teknis Pendayagunaan Tanah Terlantar Tahun 2018, (Jakarta: Direktorat Penertiban dan Pendayagunaan Tanah Terlantar \& Direktorat Jenderal Pengendalian Pemanfaatan Ruang dan Penguasaan Tanah Kementerian Agraria dan Tata Ruang/ Badan Pertanahan Nasional,2018) hlm 1. Lihat juga Satria Sukananda, Arti Penting Pendaftaran Tanah, https:/ / metrojambi.com/read/2019/05/21/43755/arti-penting-pendaftaran-tanah, Akses pada tanggal 21 Juni 2019.

161 Petunjuk Teknis Pendayagunaan Tanah Terlantar Tahun 2018...ibid. 
kehidupan manusia. Hal ini ditunjukkan dalam berbagai ungkapan daerah:162

"Sakdhumuk botok senyari bumi, yen perli ditohi pati" atau "ango' apoteya tolang ebanding apoteya mata" atau "uissi la pernah meringat" atau "ulos no so boi maribak".

Ungkapan-ungkapan ini menggambarkan kedudukan dan fungsi tanah yang begitu angat penting bagi kehidupan manusia. Tanah merupakan sumber penghidupan karena dari tanah mengalir semangat harga diri, kemakmuran, kekuasaan, dan kesakralan. Oleh karenanya, setiap orang berjuang untuk memiliki tanah dan mempertahankannya. Perjuangan tersebut disertai tekad bulat untuk mengobarkannya nyawa daripada menanggung malu atau kehilangan harga karena tidak punya tanah.

Secara yuridis normatif pengaturan prinsip-prinsip penguasaan dan pemanfaatan tanah diletakkan di dalam ketentuan Pasal 33 ayat (3) UUD 1945, yang selengkapnya dirumuskan bahwa: "Bumi dan air dan kekayaan alam yang terkandung di dalam dikuasai oleh Negara dan dipergunakan untuk sebesar-besarnya kemakmuran rakyat". Mencermati ketentuan Pasal 33 ayat (3) UUD 1945 tersebut, maka dapat disimpulkan bahwa ketentuan pasal tersebut mencerminkan adanya perintah kepada negara agar bumi, air, luar angkasa, dan kekayaan alam yang diletakkan dalam kekuasaan negara untuk mewujudkan kesejahteraan seluruh rakyat Indonesia. ${ }^{163}$

Kecenderungan penguasaan tanah yang terpusat dalam luasan yang sangat besar menjadikan pengusahaan tanah tersebut menjadi tidak optimal, bahkan cenderung dibiarkan terlantar sehingga tanah tersebut menjadi tidak berdaya guna

162 Departemen Penerangan RI, Pertanahan Dalam Era Pembangunan Nasional, (Jakarta: Ditjen Agraria Departemen Dalam Negeri, 1982) hlm. 18.

163 Saripudin, Konsep Penertiban dan Pendayagunaan Tanah Terlantar Dalam Perspektif Reforma Agraria, Jurnal Ilmu Hukum Vol. 11, No. 22, Hlm. 110153 (Agustus, 2015) hlm 111 
dan berhasil guna, baik bagi yang menguasai tanah tersebut, pemerintah, maupun bagi masyarakat sekitarnya. ${ }^{164}$

Penelantaran tanah harus dicegah dan ditertibkan untuk mengurangi atau menghapus dampak negatifnya. Pencegahan, penertiban, dan pendayagunaan tanah terlantar merupakan langkah dan prasyarat penting untuk menjalankan program-program pembangunan nasional, terutama di bidang agraria yang telah diamanatkan oleh UUD 1945. 165

Tindakan pemerintah untuk menertibkan tanah-tanah terlantar adalah mutlak diperlukan. Oleh karena itu, pemerintah menerbitkan Peraturan Pemerintah Nomor 11 Tahun 2010 tentang Penertiban dan Pendayaguna Tanah Terlantar. Sebagai pelaksana peraturan pemerintah tersebut maka diterbitkan Peraturan Kepala Badan Pertanahan Nasional Republik Indonesia Nomor 4 Tahun 2010 tentang Tata Cara Penertiban Tanah Terlantar Jo. Peraturan Kepala Badan Pertanahan Nasional Republik Indonesia Nomor 9 Tahun 2011 tentang Perubahan Atas Peraturan Kepala Badan Pertanahan Nasional Republik Indonesia Nomor 4 Tahun 2010 Tentang Tata Cara Penertiban Tanah Terlantar dan Peraturan Kepala Badan Pertanahan Nasional Republik Indonesia Nomor 5 Tahun 2011 tentang Tata Cara Pendayagunaan Tanah Negara Bekas Tanah Terlantar. Hal ini yang menjadi inspirasi penulis untuk melakukan kajian politik hukum mengenai pengaturan penertiban dan pendayagunaan tanah terlantar di Indonesia, khususnya terkait ketepatan pengaturan tersebut untuk mewujudkan penggunaan dan pemanfaatan tanah yang optimal di Indonesia sebagaimana diamanatkan oleh Undang-Undang Dasar Republik Indonesia Tahun 1945.

Menurut Padmo Wahjono pada dasarnya politik hukum adalah kebijakan penyelenggaraan negara yang bersifat mendasar dalam menentukan arah, bentuk, maupun isi dari hukum yang akan dibentuk dan tentang apa yang dijadikan

164 Petunjuk Teknis Pendayagunaan Tanah Terlantar Tahun 2018...Op.cit., hlm 1

165 Saripudin, Konsep Penertiban dan Pendayagunaan Tanah Terlantar....Op.cit., hlm 114 
sebagai kriteria untuk mengukuhkan sesuatu yang berkaitan dengan hukum yang akan datang. ${ }^{166}$ Sedangkan Soedarto mempunyai pandangan bahwa politik hukum sebagai kebijakan dari negara melalui badan- badan negara yang berwenang untuk menetapkan peraturan yang dikehendaki, yang diperkirakan akan digunakan untuk mengekspresikan apa yang dikandung dalam masyarakat dan mencapainya apa yang dicita-citakan. 167 Kemudian dari beberapa pendapat yang kemukakan oleh para sarjana hukum Indonesia ini, Moh Mahfud MD mencoba meringkasnya dengan memberikan definisi bahwa politik hukum adalah arahan atau garis resmi yang dijadikan dasar pijak dan cara untuk membuat dan melaksanakan hukum dalam rangka mencapai tujuan bangsa dan negara. ${ }^{168}$ Lebih lanjut Mahfud menegaskan bahwa politik hukum adalah legal policy atau garis kebijakan resmi tentang hukum yang akan diberlakukan baik dengan pembuatan hukum baru maupun dengan penggantian hukum lama dalam rangka mencapai tujuan negara. ${ }^{169}$

Dari definisi yang diutarakan oleh para sarjana hukum di atas dapat ditarik kesimpulan bahwa studi politik hukum adalah studi balik layar, yang maksudnya adalah studi dibalik dari undang-undang sebagai norma hukum apa yang sebenarnya terjadi ketika perumusan dan pembentukan undang-undang itu terjadi. Apakah benar-benar undang-undang tersebut dibentuk untuk masyarakat atau hanya kepentingan sesaat bagi politisi. Untuk menganalisa suatu undang-undang dapat dilihat dari sebuah kondisi politik di suatu negara. Hal ini dikarenakan pembentukan sebuah

166 Padmo Wahjono, Indonesia Negara Berdasarkan Atas Hukum cet II, (Jakarta: Ghalia Indonesia, 1986) hlm 160.

167 Soedarto, Perkembangan Ilmu Hukum dan politik Hukum dalam Hukum dan Keadilan, atau Lihat juga Abdul Manan Politik Hukum Studi Perbandingan dalam Praktik Ketatanegaraan Islam dan Sistem Hukum Barat, (Jakarta: Prenada Media Grup, 2016) hlm 9.

${ }_{168}$ Moh Mahfud MD, Membangun Politik Hukum Menegakkan Konstitusi, ( Jakarta: Raja Grafindo Persada, 2011) hlm 15.

${ }_{169}$ Moh Mahfud MD, Politik Hukum Di Indonesia, (Jakarta: Raja Grafindo Persada, 2012) hlm 1. 
peraturan perundang-undangan tidak bisa dilepaskan dengan fenomena politik yang terjadi. Hal ini dilatarbelakangi dengan adanya kekuatan politik yang ada di belakang Undang-undang tersebut. Fenomena ini menegaskan bahwa hukum dalam artian sebagai peraturan yang abstrak. Pasal-pasal imperatif merupakan kristalisasi dari kehendak-kehendak politik yang saling berinteraksi dan beririsan. Sidang parlemen bersama pemerintah untuk membuat undang-undang sebagai produk hukum pada hakikatnya merupakan adegan kontestasi agar kepentingan dan aspirasi semua kekuatan politik terakomodasi di dalam keputusan politik menjadi Undang-Undang. ${ }^{170}$

Dari uraian di atas, permasalahan yang diangkat dalam penulisan hukum ini adalah bagaimana pengaturan dan prosedur hukum penertiban dan pendayagunaan tanah terlantar di Indonesia, bagaimana dampaknya terhadap optimalisasi penggunaan dan pemanfaatan tanah di Indonesia, dan bagaimana alternatif politik hukum penertiban dan pendayagunaan tanah terlantar di masa depan dalam rangka mengurangi dampak negatif dari pengaturan penertiban dan pendayagunaan tanah terlantar saat ini.

B. Pengaturan dan Prosedur Hukum Penertiban dan Pendayagunaan Tanah Terlantar di Indonesia dan Dampaknya Terhadap Optimalisasi Penggunaan dan Pemanfaatan Tanah Di Indonesia

1. Pengertian Tanah Terlantar

Negara memberikan hak atas tanah atau hak pengelolaan kepada Pemegang Hak untuk diusahakan, dipergunakan, dan dimanfaatkan serta dipelihara dengan baik selain untuk kesejahteraan bagi Pemegang Hak juga ditujukan untuk kesejahteraan masyarakat, bangsa, dan negara. ketika Negara memberikan hak kepada orang atau badan hukum selain diiringi kewajiban-kewajiban yang ditetapkan dalam Undang-Undang Nomor 5 Tahun 1960 tentang Peraturan Dasar Pokok-Pokok Agraria dan surat

170 Ibid, hlm 10 
keputusan pemberian haknya. ${ }^{171}$ Pemegang Hak dilarang menelantarkan tanahnya, dan jika pemegang hak menelantarkan tanahnya, Peraturan Dasar Pokok-Pokok Agraria telah mengatur akibat hukumnya yaitu hapusnya hak atas tanah yang bersangkutan dan pemutusan hubungan hukum serta ditegaskan sebagai tanah yang dikuasai langsung oleh Negara. Bagi tanah yang belum ada hak atas tanahnya melainkan hanya dasar penguasaan semata, penggunaan atas tanah tersebut harus dilandasi dengan sesuatu hak atas tanah sesuai Pasal 4 juncto Pasal 16 Undang-Undang Nomor 5 Tahun 1960 tentang Peraturan Dasar Pokok-Pokok Agraria. Oleh karena itu, orang atau badan hukum yang telah memperoleh dasar penguasaan tanah, baik dengan pengadaan tanah itu dari hak orang lain, memperoleh penunjukan dari pemegang hak pengelolaan, memperoleh izin lokasi, atau memperoleh keputusan pelepasan kawasan hutan berkewajiban memelihara tanahnya, mengusahakannya dengan baik, tidak menelantarkannya, serta mengajukan permohonan untuk mendapatkan hak atas tanah. Meskipun yang bersangkutan belum mendapat hak atas tanah, apabila menelantarkan tanahnya maka hubungan hukum yang bersangkutan dengan tanahnya akan dihapuskan dan ditegaskan sebagai tanah yang dikuasai oleh Negara.

Oleh sebab itu, penelantaran tanah harus dicegah dan ditertibkan untuk mengurangi atau menghapus dampak negatifnya. Dengan demikian pencegahan, penertiban, dan pendayagunaan tanah terlantar merupakan langkah dan prasyarat penting untuk menjalankan program-program pembangunan nasional, terutama di bidang agraria yang telah diamanatkan oleh Undang-Undang Dasar Negara

171 Sahna, M. Yazid Fathoni dan Musakir Salat, Penerapan Prinsip Keadilan dalam Pembebasan Tanah Bagi Pembangunan untuk Kepentingan Umum, Jurnal Ius (Kajiian Hukum dan Keadilan), Vol. 3 No.9, (Desember 2015), hlm.422 
Republik Indonesia Tahun 1945 dan Peraturan Dasar Pokok-Pokok Agraria. ${ }^{172}$

Secara umum pengertian tanah terlantar adalah tanah yang tidak diusahakan atau dimanfaatkan. Menurut Peraturan Kepala Badan Pertanahan Nasional Republik Indonesia Nomor 4 Tahun 2010 tentang Tata Cara Penertiban Tanah Terlantar Jo. Peraturan Kepala Badan Pertanahan Nasional Republik Indonesia Nomor 9 Tahun 2011 tentang Perubahan Atas Peraturan Kepala Badan Pertanahan Nasional Republik Indonesia Nomor 4 Tahun 2010 Tentang Tata Cara Penertiban Tanah Terlantar, dibedakan antara tanah diindikasi terlantar dengan tanah terlantar. Tanah yang diindikasii terlantar adalah tanah yang diduga tidak diusahakan, atau tidak dimanfaatkan sesuai dengan keadaan atau sifat dan tujuan pemberian hak atau dasar penguasaannya yang belum dilakukan identifikasi dan penelitian. Adapun tanah terlantar adalah tanah yang sudah diberikan hak oleh negara berupa Hak Milik, Hak Guna Usaha, Hak Guna Bangunan, Hak Pakai, dan Hak Pengelolaan, atau dasar penguasaan atas tanah yang tidak diusahakan, tidak digunakan, atau tidak dimanfaatkan sesuai dengan keadaannya atau sifat dan tujuan pemberian hak atau dasar penguasaannya. ${ }^{173}$

Secara fisik tanah terlantar pada umumnya merupakan tanah yang ditumbuhi semak belukar atau tidak terurus. Selain itu, menurut kategori penggunaan tanah, tanah terlantar adalah tanah yang tidak dimanfaatkan sesuai dengan tujuan pemberian hak. Sebagai contoh semula yang direncanakan dalam SK Pemberian hak adalah untuk penanaman karet ternyata yang ditanam adalah kelapa sawit. ${ }^{174}$

172 Zaki Ulya, Ekspaktasi Pengelolaan Tanah Terlantar Oleh Baitul Mal Dalam Peningkatan Kesejahteraan Masyarakat, Jurnal Hukum dan Pembangunan, Vol. 46 No. 4 (Oktober-Desember 2016), hlm. 509.

173 Waskito dan Hadi Arnowo, Pertanahan, Agraria, dan Tata Ruang, (Jakarta: Kencana Prenada Media Group, 2018). Hlm. 313

174 Ibid. 
Kewajiban pemilik tanah untuk memanfaatkan tanah secara aktif merupakan amanat dari Pasal 10 Undang-Undang Pokok Agraria (UUPA). Amanat tersebut dapat dimaklumi mengingat ketersediaan tanah semakin terbatas sementara kebutuhan akan tanah semakin meningkat. Apabila tanah yang telah dimiliki dan dikuasai tidak diusahakan atau dimanfaatkan tidak saja melanggar UUPA di atas tetapi juga masuk kategori tanah telantar berdasarkan peraturan perundang-undangan yang berlaku.

Pada waktu diterbitkannya UUPA sekitar tahun 1960-an, tanah di Indonesia relatif masih tersedia secara luas tetapi oleh UUPA sudah diingatkan akan kewajiban pemilik tanah untuk memanfaatkan tanah. Sangat memungkinkan akan terjadi pengelompokan atau pemusatan pemilikan tanah tetapi tidak dimanfaatkan dengan tujuan spekulasi harga tanah yang dapat menyebabkan ketimpangan sosial. Semakin bertambahnya penduduk Indonesia sementara fenomena penumpukan luas areal tanah dalam skala luas mulai marak terjadi mendorong pemerintah membuat regulasi tentang penertiban tanah terlantar.

Regulasi mengenai tanah terlantar yang pertama kali lahir adalah PP Nomor 36 Tahun 1998 tentang Penertiban dan Pendayagunaan Tanah Terlantar. Di dalam peraturan tersebut diatur mengenai kriteria tanah terlantar, tata cara penertiban dan pendayagunaan, serta tindakan terhadap tanah terlantar. Lahirnya peraturan tersebut dalam perjalanan waktu masih dirasakan kurang efektif karena memberi peluang kepada pemilik tanah untuk menyiasati langkah-langkah penertiban.

Kelemahan yang terdapat dalam peraturan tersebut di atas kemudian mendorong lahirnya Peraturan Pemerintah Nomor 11 Tahun 2010 tentang Penertiban dan Pendayaguna Tanah Terlantar. Selanjutnya sebagai pelaksana peraturan pemerintah tersebut maka diterbitkan Peraturan Kepala Badan Pertanahan Nasional Republik Indonesia Nomor 4 Tahun 2010 tentang Tata Cara 
Penertiban Tanah Terlantar Jo. Peraturan Kepala Badan Pertanahan Nasional Republik Indonesia Nomor 9 Tahun 2011 tentang Perubahan Atas Peraturan Kepala Badan Pertanahan Nasional Republik Indonesia Nomor 4 Tahun 2010 Tentang Tata Cara Penertiban Tanah Terlantar. Dalam Pasal 2 Peraturan Pemerintah Nomor 11 Tahun 2010 tentang Penertiban dan Pendayagunaan Tanah Terlantar yang menyatakan bahwa: ${ }^{175}$

Obyek penertiban tanah terlantar meliputi tanah yang sudah diberikan hak oleh Negara berupa Hak Milik, Hak Guna Usaha, Hak Guna Bangunan, Hak Pakai, dan Hak Pengelolaan, atau dasar penguasaan atas tanah yang tidak diusahakan, tidak dipergunakan, atau tidak dimanfaatkan sesuai dengan keadaannya atau sifat dan tujuan pemberian hak atau dasar penguasaannya.

Pengecualian objek tanah terlantar berdasarkan aturan tersebut di atas adalah:

a. Tanah Hak Milik atau Hak Guna Bangunan atas nama perseorangan yang secara tidak sengaja tidak digunakan sesuai dengan keadaan atau sifat dan tujuan pemberian haknya;

b. Tanah yang dikuasai pemerintah baik secara langsung maupun tidak langsung dan sudah berstatus maupun belum berstatus Barang Milik Negara/Daerah yang tidak sengaja tidak digunakan sesuai keadaan atau sifat dan tujuan pemberian haknya.

\section{Identifikasi Tanah Terlantar}

Disadari penanganan tanah terlantar akan berhadapan dengan konsekuensi hukum, maka diperlukan langkah-langkah penanganan yang jelas dan tegas. Di dalam

175 Peraturan Pemerintah Nomor 11 Tahun 2010 tentang Penertiban dan Pendayagunaan Tanah Terlantar 
peraturan mengenai tanah terlantar telah diatur langkah-langkah penanganan sebagai berikut:

a. Inventarisasi tanah hak atau dasar penguasaan atas tanah yang terindikasi terlantar;

b. Identifikasi dan penelitian tanah terindikasi terlantar;

c. Rapat Panitia C;

d. Peringatan terhadap pemegang hak;

e. Penetapan tanah terlantar.

Data tanah terlantar berasal dari hasil pemantauan lapangan oleh Kantor Wilayah, Kantor Pertanahan, atau dari laporan dinas/instansi lainnya, laporan tertulis dari masyarakat, atau pemegang hak. Selain laporan adanya tanah terlantar, data lain sebagai pembanding adalah laporan penggunaan dan penguasaan tanah dari pemegang hak.

Inventarisasi data tanah terlantar dilakukan melalui:

a. Pengumpulan data mengenai tanah yang terindikasi terlantar meliputi data tekstual dan data spasial;

1) Data tekstual meliputi nama dan alamat pemegang hak, nomor, dan tanggal keputusan pemberian hak, nomor, tanggal, dan berakhirnya sertipikat, letak tanah, luas tanah, penggunaan tanah, luas tanah terindikasi terlantar;

2) Data spasial merupakan data grafis berupa peta yang dilengkapi dengan koordinat posisi bidang tanah terindikasi terlantar;

b. Pengelompokan data tanah yang terindikasi terlantar yang terhimpun menurut wilayah kabupaten/kota dan jenis hak/dasar penguasaan dengan format yang telah ditentukan;

c. Pengadministrasian data hasil inventarisasi tanah terindikasi terlantar dan diselenggarakan secara tertib dalam basis data untuk keperluan pelaporan, bahan analisis, dan penentuan tindakan selanjutnya. 
Hasil inventarisasi tanah terindikasi terlantar ditindaklanjuti dengan identifikasi dan penelitian aspek administrasi dan penelitian lapangan meliputi:

a. Hak milik, Hak Guna Usaha, Hak Guna Bangunan, dan Hak Pakai terhitung mulai 3 (tiga) tahun sejak diterbitkannya sertipikat;

b. Tanah yang telah memperoleh izin/keputusan/surat dasar penguasaan atas tanah dari pejabat yang berwenang terhitung sejak berakhirnya dasar penguasaan tersebut.

Kepala Kantor Wilayah menganalisis hasil inventarisasi untuk menyusun dan menetapkan target yang akan dilakukan idenfitikasi dan penelitian terhadap tanah terindikasi terlantar. Penetapan target berdasarkan pertimbangan lamanya tanah tersebut ditelantarkan dan/atau luas tanah yang terindikasi terlantar. Langkah-langkah yang dilakukan dalam kegiatan identifikasi adalah:

a. Verifikasi data fisik dan data yuridis meliputi jenis hak dan letak tanah;

b. Mengecek buku tanah dan/atau warkah dan dokumen lainnya untuk mengetahui keberadaan pembebanan, termasuk data, rencana, dan tahapan penggunaan, dan pemanfaatan tanah pada saat pengajuan hak;

c. Meminta keterangan dari pemegang hak dan pihak lain terkait apabila pemegang hak/kuasa/wakil tidak memberikan data dan informasi atau tidak di tempat atau tidak dapat dihubungi, maka identifikasi dan penelitian tetap dilaksanakan dengan cara lain untuk memperoleh data;

d. Melaksanakan pemeriksaan fisik berupa letak batas, penggunaan dan pemanfaatan tanah dengan menggunakan teknologi yang ada; 
e. Melaksanakan plotting letak penggunaan dan pemanfaatan tanah pada peta pertanahan berdasarkan hasil pemeriksaan fisik;

f. Membuat analisis penyebab terjadinya tanah terlantar antara lain menyangkut permasalahan-permasalahan penyebab terjadinya tanah terlantar, kesesuaian dengan hak yang diberikan, dan kesesuaian dengan tata ruang;

g. Menyusun laporan hasil identifikasi dan penelitian dengan format tertentu.

Pada tahapan pengumpulan data, Kepala Kantor Wilayah memberitahukan secara tertulis kepada pemegang hak bahwa akan dilakukan identifikasi dan penelitian. Pemberitahuan secara tertulis disampaikan langsung kepada pemegang hak sesuai alamat atau domisili pemegang hak. Jika tidak dijumpai lagi sesuai alamat atau domisili, maka pemberitahuan dilakukan melalui pengumuman di Kantor Pertanahan dan pemasangan papan pengumumman di lokasi tanah yang bersangkutan bahwa tanah tersebut sedang dalam tahap identifikasi dan penelitian oleh BPN. ${ }^{176}$

a. Rapat Panitia C

Setelah data hasil identifikasi dan penelitian dinilai cukup sebagai bahan pengambilan keputusan upaya penertiban. Kepala Kantor Wilayah membentuk Panitia C yang terdiri dari unsur Kantor Wilayah Badan Pertanahan Nasional, Kantor Pertanahan, Pemerintah Daerah, dan instansi yang berkaitan dengan peruntukan tanah yang bersangkutan.

Susunan keanggotaan menurut Peraturan Kepala BPN RI Nomor 9 Tahun 2011 adalah:

1) Ketua: Kepala Kantor Wilayah;

176 Petunjuk Teknis Pendayagunaan Tanah Terlantar Tahun 2019, (Jakarta: Direktorat Penertiban dan Pendayagunaan Tanah Terlantar \& Direktorat Jenderal Pengendalian Pemanfaatan Ruang dan Penguasaan Tanah Kementerian Agraria dan Tata Ruang/ Badan Pertanahan Nasional, 2019), hlm. 20 
2) Sekretaris: Kepala Bidang Pengendalian Pertanahan dan Pemberdayaan Masyarakat, merangkap anggota;

3) Anggota:

a) Sekretaris Daerah Kabupaten/Kota atau memberikan kuasa kepada pejabat struktural di bawahnya minimal Eselon III;

b) Dinas/Instansi Provinsi yang berkaitan dengan peruntukan tanahnya;

c) Dinas/Intansi Kabupaten/Kota yang berkaitan dengan peruntukan tanahnya;

d) Kepala Kantor Pertanahan.

Untuk membantu Panitia C, Kepala Kantor Wilayah membentuk sekretariat. Sekretariat Panita C membantu menyiapkan semua data yang diperlukan dan membuat resume permasalahan tanah yang terindikasi terlantar dan menjalankan tugas administrasi kesekretariatan.

Berdasarkan data yang dilaporkan, Panitia C melakukan identifikasi dan penelitian, meliputi: ${ }^{177}$

1) Melakukan verifikasi data fisik dan data yuridis;

2) Mengecek buku tanah dan/atau warkah dan dokumen lainnya untuk mengetahui keberadaan pembebanan, termasuk data, rencana, dan tahapan penggunaan dan pemanfaatan tanah pada saat pengajuan hak;

3) Meminta keterangan dari pemegang hak dan pihak lain yang terkait, dan Pemegang Hak dan pihak lain harus memberi keterangan atau menyampaikan data yang diperlukan;

4) Melaksanakan pemeriksaan fisik dengan menggunakan teknologi yang ada;

5) Melaksanakan ploting letak penggunaan dan pemanfaatan tanah pada peta pertanahan; 
6) Membuat analisis penyebab terjadinya tanah terlantar;

7) Menyusun laporan hasil idenfitikasi dan penelitian;

8) Melaksanakan sidang panitia untuk membahas dan memberikan saran pertimbangan kepada Kepala Kantor Wilayah dalam rangka tindakan penertiban tanah terlantar;

9) Membuat dan menandatangani Berita Acara dengan format tertentu.

\section{Penanganan Tanah Terlantar}

Apabila hasil identifikasi dan penelitian disimpulkan terdapat tanah yang ditelantarkan, Kepala Kantor Wilayah memberitahukan kepada pemegang hak dan sekaligus memberikan peringatan. Jumlah peringatan sebanyak 3 (tiga) kali. Jangka waktu peringatan hanya 1 (satu) bulan sejak diterbitkan surat peringatan. Isi dari surat peringatan secara umum adalah pemegang hak harus mengusahakan, menggunakan, dan memanfaatkan tanahnya sesuai tujuan pemberian haknya atau dasar penguasaannya yang akan dievaluasi kembali 1 (satu) bulan sejak diterbitkan surat peringatan. Sedangkan secara detil surat peringatan pertama menyebutkan hal-hal konkret yang harus dilakukan oleh pemegang hak dan sanksi yang dapat dijatuhkan apabila pemegang hak tidak mengindahkan atau tidak melaksanakan peringatan dimaksud.

Data luas tanah yang ditelantarkan yang digunakan untuk bahan pembuatan surat peringatan pertama adalah data dari hasil identifikasi penelitian Panita C, sedangkan data untuk surat peringatan kedua dan ketiga adalah data pada akhir peringatan sebelumnya. Tindakan konkret yang harus dilakukan Pemegang Hak terhadap peringatan yang dilayangkan oleh Kepala Kantor Wilayah, antara lain:178 
a. Mengusahakan, menggunakan, dan memanfaatkan tanahnya sesuai keadaan atau sifat dan tujuan pemberian haknya;

b. Dalam hal tanah yang digunakan tidak sesuai dengan sifat dan tujuan pemberian haknya, pemegang hak harus mengajukan permohonan perubahan hak atas tanah kepada Kepala sesuai dengan peraturan yang berlaku;

c. Mengajukan permohonan hak untuk dasar penguasaan atas tanah mengusahakan, menggunakan, atau memanfaatkan tanahnya sesuai dengan izin/keputusan/surat dari pejabat yang berwenang.

Sanksi yang dapat dijatuhkan terhadap pemegang hak karena tidak dapat memenuhi persyaratan yang disebut dalam surat peringatan adalah tanah hak atau dasar penguasaan atas tanahnya ditetapkan menjadi tanah terlantar, sekaligus hapus haknya, putus hubungan hukum, dan tanahnya ditegaskan dikuasai langung oleh negara.

Dalam masa peringatan pertama, kedua, dan ketiga, pemegang hak wajib menyampaikan laporan kemajuan penggunaan dan pemanfaatan tanah yang ditelantarkan setiap 2 (dua) minggu kepada Kepala Kantor Wilayah dengan tembusan Kepala Kantor Pertanahan. Kepala Kantor Wilayah melaksanakan pemantauan dan evaluasi lapangan terhadap laporan pemegang hak pada akhir masa setiap peringatan.

Keputusan Kepala BPN disampaikan kepada pemegang hak atau bekas pemegang hak dengan tembusan kepada Gubernur, Kepala Kantor Wilayah, Bupati/Walikota, Kepala Kantor Pertanahan, instansi terkait serta kepada pemegang Hak Tanggungan apabila terdapat Hak Tanggungan. Berdasarkan keputusan tersebut, Kepala Kantor Pertanahan wajib menarik, mencoret sertipikat hak atas tanah, dan/atau sertipikat hak tanggungan dalam daftar umum dan daftar isian lainnya dalam tata usaha pendaftaran. Dalam hal Kepala Kantor Pertanahan tidak 
dapat menarik, mencoret sertipikat hak atas tanah, dan/atau Sertipikat Hak Tanggungan, maka harus mengumumkan di surat kabar 1 (satu) kali dalam waktu 1 (satu) bulan atau memasang papan pengumuman di lokasi setelah dikeluarkannya keputusan ini yang menyatakan bahwa sertipikat tersebut tidak berlaku.

a. Penetapan Tanah Terlantar

Penetapan Tanah Terlantar berdasarkan persentase luas tanah yang ditelantarkan terbagi atas: ${ }^{179}$

1) 100 persen terlantar,

2) Lebih dari 25 persen sampai dengan kurang dari 100 persen terlantar;

3) Kurang dari atau sama dengan 25 persen terlantar.

Konsekuensi dari penetapan persentase tanah terlantar adalah:

1) Apabila seluruh hamparan tanah terlantar, maka Keputusan Penetapan Tanah Terlantar diberlakukan terhadap seluruh hamparan hak atas tanah tersebut;

2) Apabila sebagian hamparan yang ditelantarkan, maka Keputusan Penetapan Tanah Terlantar diberlakukan terhadap seluruh hak atas tanah tersebut, dan selanjutnya kepada bekas pemegang Hak diberikan kembali sebagian tanah yang benar-benar diusahakan, digunakan, dan dimanfaatkan sesuai dengan keputusan pemberian haknya, dengan melalui prosedur pengajuan permohonan hak atas tanah atas biaya pemohon sesuai ketentuan peraturan perundang-undangan;

3) Apabila tanah hak yang ditelantarkan kurang dari atau sama dengan 25 (dua puluh lima) persen, maka Keputusan Penetapan Tanah Terlantar dibelakukan hanya terhadap tanah yang ditelantarkan dan selanjutnya Pemegang Hak mengajukan permohonan revisi luas bidang tanah hak tersebut dan biaya revisi 
menjadi beban Pemegang Hak sesuai ketentuan peraturan perundang-undangan.

Keputusan penetapan tanah terlantar yang telah diberikan dasar penguasaan, diberlakukan hanya terhadap tanah yang ditelantarkan, dan selanjutnya bekas pemegang dasar penguasaan tersebut mengajukan permohonan hak atas tanah sesuai dengan peraturan perundang-undangan atas bidang tanah yang benar-benar diusahakan, digunakan, dan dimanfaatkan sesuai dengan izin/keputusan/surat yang telah ditetapkan oleh yang berwenang.

\section{b. Pendayagunaan Tanah Negara Bekas Tanah Telantar}

Tanah yang ditetapkan menjadi tanah terlantar harus melalui tahapan sebagaimana diatur dalam Peraturan Kepala Badan Pertanahan Nasional Republik Indonesia Nomor 4 Tahun 2010 tentang Tata Cara Penertiban Tanah Terlantar Jo. Peraturan Kepala Badan Pertanahan Nasional Republik Indonesia Nomor 9 Tahun 2011 tentang Perubahan Atas Peraturan Kepala Badan Pertanahan Nasional Republik Indonesia Nomor 4 Tahun 2010 Tentang Tata Cara Penertiban Tanah Terlantar. Selanjutnya pengaturan tanah negara tersebut diatur dengan Peraturan Kepala Badan Pertanahan Nasional Republik Indonesia Nomor 5 Tahun 2011 tentang Tata Cara Pendayagunaan Tanah Negara Bekas Tanah Terlantar.

Tanah negara bekas tanah terlantar adalah tanah yang sudah ditetapkan sebagai tanah terlantar, dihapuskan haknya, diputus hubungan hukumnya, dan ditegaskan menjadi tanah yang dikuasai langsung oleh negara merupakan Tanah Cadangan Umum Negara (TCUN).

TCUN dialokasikan secara nasional untuk kepentingan masyarakat dan negara melalui:

1) Reforma Agraria; 
2) Program Strategis Negara;

3) Cadangan Negara lainnya.

Pengalokasian TCUN disesuaikan dengan ketersediaan tanah serta tidak dalam keadaan sengketa fisik dan yuridis. Penerima TCUN wajib:

1) Mengusahakan sendiri tanahnya;

2) Meningkatkan hasil produksi;

3) Menjaga, meningkatkan kesuburan, dan kelestarian tanahnya.

Penerima TCUN untuk alokasi program strategis negara tidak diperbolehkan untuk mengubah pengembangan sektor yang telah ditentukan. ${ }^{180}$

4. Dampak Politik Hukum Pengaturan dan Prosedur Hukum Penertiban Dan Pendayagunaan Tanah Terlantar Terhadap Optimilasi Penggunaan Dan Pemanfaatan Tanah Di Indonesia

Arah dan prinsip politik hukum Pengaturan dan Prosedur Hukum Penertiban dan Pendayagunaan Tanah Terlantar di Indonesia terhadap optimalisasi penggunaan dan pemanfaatan tanah di Indonesia yang berlangsung sampai sekarang seperti yang digambarkan di atas sampai saat ini masih menimbulkan beberapa persoalan yaitu:

a. Konflik kewenangan antarinstansi pemerintah yang terkait dengan penertiban dan pendayaguanaan tanah terlantar, yang mana instansinya yaitu Kementerian Agraria dan Tata Ruang/Badan Pertanahan Nasional, Kementerian Kehutanan, Kementerian Pertanian dan kementerian terkait lainnya. Sumber konfliknya adalah berdasarkan Peraturan Pemerintah Nomor 11 Tahun 2010 tentang Penertiban dan Pendayagunaan Tanah Terlantar, Peraturan Kepala Badan Pertanahan Nasional

180 Waskito dan Hadi Arnowo, Pertanahan, Agraria, dan Tata Ruang..op.cit. hlm. 320 . 
Republik Indonesia Nomor 4 Tahun 2010 tentang Tata Cara Penertiban Tanah Terlantar Jo. Peraturan Kepala Badan Pertanahan Nasional Republik Indonesia Nomor 9 Tahun 2011 tentang Perubahan Atas Peraturan Kepala Badan Pertanahan Nasional Republik Indonesia Nomor 4 Tahun 2010 Tentang Tata Cara Penertiban Tanah Terlantar, salah satu objek yang dapat dilakukan identifikasi dan penelitian terhadap tanah terindikasi terlantar adalah Dasar Penguasaan Atas Tanah (DPAT) yang selanjutnya dapat berbentuk izin/keputusan/surat dari pejabat yang berwenang yang menjadi dasar bagi orang atau badan hukum untuk menguasai, menggunakan, atau memanfaatkan tanah, dapat berupa Izin Lokasi dan Pelepasan Kawasan Hutan. Di satu pihak terdapat produk hukum di luar Hak Atas Tanah yang diterbitkan oleh Kementerian terkait sedangkan yang dapat melakukan identifikasi dan penelitian hingga penetapan tanah telantar adalah Kementerian Agraria dan Tata Ruang/Badan Pertanahan Nasional yang sudah jelas Dasar Penguasaan Atas Tanah (DPAT) bukan merupakan produk hukumnya. Secara normatif yuridis, ketentuan hukum ini menimbulkan konfilik horizontal antar lembaga Kementerian.

b. Arah dan prinsip politik hukum Pengaturan dan Prosedur Hukum Penertiban dan Pendayagunaan Tanah Terlantar di Indonesia yang kapitalistik dan liberal ${ }^{181}$ yang digunakan selama ini memang di satu sisi telah menimbulkan kemajuan dalam penguasaan dan pemanfaatan tanah di Indonesia. Namun di balik keberhasilan atau dampak positif tersebut, politik hukum Pengaturan dan Prosedur Hukum Penertiban dan Pendayagunaan Tanah Terlantar di Indonesia juga telah

181 Nurhasan Ismail, Arah Politik Hukum Pertanahan dan Perlindungan Kepemilikan Tanah Masyarakat (Political Direction of Land Law and Protection of People's Land Ownership, Jurnal RechtVinding Media Pembinaan Hukum Nasional, Volume 1 Nomor 1, April (2020) hlm. 41 
mendatangkan dampak sampingan negatif. Di antara dampak sampingan negatifnya adalah:

1) Terjadinya kesenjangan dalam penguasaan dan pemanfaatan sumber daya alam berupa tanah. Dengan kata lain ada ketimpangan dalam distribusi penguasaan dan pemilikan tanah. Ada sekelompok kecil subyek menguasai dan menfaatkan tanah yang sangat luas/besar, namun sebagian besar warga masyarakat hanya menguasai dan memanfaatkan bagian sumber daya yang relatif terbatas. Secara umum, tingkat kesenjangan semakin meningkat seperti ditunjukkan oleh Indeks Gini sebesar 0,308 pada tahun 1999 dan 0,363 pada tahun 2005.182 Data di bidang pertanahan menunjukkan bahwa 0,2 \% dari pendudukan Indonesia menguasai sekitar $56 \%$ aset berupa properti, perkebunan, dan tanah pertanian. ${ }^{183}$, sehingga ada $99,80 \%$ penduduk Indonesia yang harus bersaing menguasai dan menfaatkan sisanya sebesar $44 \%$. Data lain di bidang pertanian menunjukkan bahwa pada tahun 2003 sebanyak 70\% rumah tangga petani hanya menguasai tanah pertanian rata-rata sebesar 0,17 Ha. ${ }^{184}$ Sebaliknya ada $10 \%$ pendudukan pedesaan yang menguasai $55,3 \%$ tanah pertanian. ${ }^{185}$ Bahkan jika dibandingkan dengan sektor perkebunan kelapa sawit, setiap perusahaan rata-rata menguasai

182 Joyo Winoto, Mandat Politik, Konstitusi dan Hukum Dalam Rangka Mewujudkan Tanah Untuk Keadilan dan Kesejahteraan Rakyat, tulisan yang disampaikan dalam Kuliah Umum di Balai Senat Universita Gadjah Mada, Bulaksumur- Yogyakarta, 2007, hlm. 5 di dalam Nurhasan Ismail, Arah Politik Hukum Pertanahan dan Perlindungan... ibid.

183 webugm@ugm.ac.id, Ketimpangan Kepemilikan Aset Sebagai Penyebab Kemiskinan, (Yogyakarta: Universitas Gadjah Mada, 2008)

184 Zulfadhli, H, Tanah Untuk Petani, tulisa yang disampaikan dalam Seminar Nasional HKTI "Reforma Agraria, Pelaksanaan Otonomi Daeran, dan Penataan Ruang, 2009; lihat juga Iwan N. Selamat, Ketimpangan Struktur Agraria Indonesia, 2009, di dalam dalam Nurhasan Ismail, Arah Politik Hukum Pertanahan dan Perlindungan... op.cit.

${ }^{185}$ Khudori, Petani Kemisikan, dan Reforma Agraria, dalam Kompas, Jakarta, 16 Maret 2007. 
7.500 Ha. ${ }^{186}$ Data kuantitatif di atas memang tidak mutakhir, namun secara kualitatif kesenjangan khususnya di perkotaan dapat dicermati dari fakta, yaitu: (1) Betapa sulitnya memperoleh tanah bagi pembangunan rumah susun milik atau rumah susun sewa yang diperuntukkan bagi kelompok masyarakat berpenghasilan rendah, namun sebaliknya begitu sangat mudahnya perolehan tanah untuk membangun rumah mewah atau menengah bagi kelompok masyarakat menengah ke atas; ${ }^{187}$ Sulitnya kaum miskin perkotaan mendapatkan ruang tempat berusaha, bahkan tempat usaha kecil atau pasar tradisional yang sudah ada mengalami kemandegan atau penggusuran. 188 Sebaliknya penyediaan ruang tanah bagi pasar-pasar modern seperti mall atau bisnis ritel dan bagi pembangunan kantor pemerintah dengan mudah dapat disediakan. ${ }^{189}$ Pelan tapi pasti dengan kemudahan itu telah menggusur dan meminggirkan kelompok miskin perkotaan dan pedagang tradisional. ${ }^{190}$ (3) Sempitnya ruang pedestarian bagi pejalan kaki pesepeda karena ruang lalu lintas hanya diperuntukkan bagi kendaraan pribadi. Konsekuensinya, pejalan kaki atau pesepeda harus berjalan di ruang pedestrian yang sempit atau

186 NN, Palm Oil Problem: Plantation Companies in Conflict With Villagers, Tuesday, May, 19th, dalam Jakarta Post, Jakarta, 2009, hlm. 5 di dalam Nurhasan Ismail, Arah Politik Hukum Pertanahan dan Perlindungan... ibid.

187 Eko Budihardjo, Metropolis atau Miseropolis, dalam Kompas, Jakarta, Sabtu 22 September 2007, hlm.6. di dalam Nurhasan Ismail, Arah Politik Hukum Pertanahan dan Perlindungan... ibid.

188 Lucinda, Di Tengah Kepungan Bisnis Ritel, dalam Harian Bernas, Yogyakarta, tanggal 18 Mei 2020, hlm.4. di dalam Nurhasan Ismail, Arah Politik Hukum Pertanahan dan Perlindungan... ibid.

189 Kompas, Tanah Perkotaan dan Perlindungan Rakyat Jelata, Tajuk Rencana, 2008.

190 Patrick McAusian, Tanah Perkotaan dan Perlindungan Rakyat Jelata, (Jakarta: PT. Gramedia, 1986), hlm. 16. 
menggunkan badan jalan dengan risiko tertabrak kendaraan bermotor.

2) Realitas kemiskinan masih menjadi problem bangsa Indonesia. Jika diukur dengan patokan angka garis kemiskinan yang digunakan pemerintah pada tahun 2010 yaitu sebesar Rp211.726,00 perkapita/bulan, maka pada tahun 2010 masih terdapat $13.33 \%$ atau 31,2 juta orang miskin. ${ }^{191}$ Jumlah orang miskin akan semakin tinggi lagi jika memasukkan orang yang memperoleh penghasilan tepat pada angka garis kemiskinan atau menggunakan angka garis kemiskinan yang ditetapkan Perserikatan Bangsa-Bangsa yaitu sebesar US\$3 atau sekitar Rp750.000,00 perkapita/bulan. ${ }^{192}$ Terlepas dari pro-kontra kriteria dan jumlah orang miskin, jumlah orang miskin di beberapa daerah berada di atas rata-rata angka kemiskinan nasional yaitu mencapai 2-3 kali lipat. Sebagian besar orang miskin itu berada di daerah pedesaan yaitu mencapai $64,23 \%$ pada tahun 2010. Sebagian daerah yang menjadi kantong-kantong kemiskinan tersebut mempunyai sumber daya alam yang relatif terbatas, namun sebagian lainnya berada di wilayah yang mempunyai sumber daya alam yang sangat kaya. Kantong kemiskinan yang terdapat di daerah yang miskin sumber daya alam masih dapat dipahami meskipun itu menunjukkan kurang maksimalnya pelaksanaan tanggung jawab negara. Sebaliknya, suatu keprihatian besar dan pertanyaan mendasar harus dikemukakan terhadap kantong kemiskinan yang terdapat di daerah yang sangat kaya sumber daya alam seperti di Papua, Kalimantan, dan Sumatera termasuk di wilayah pesisirnya.

191 Berita Resmi Statistik, Profil Kemiskinan di Indonesia 2010, dalam Berita Resmi Statistik No. 45/07/Th XIII, (Jakarta:Badan Pusat Statistik, 1 Juli 2010).

192 Kompas, 2011, Kemiskinan Tampak Nyata, Senin, 15 Agustus, hlm. 15. 
Persoalan-persoalan sebagaimana dijelaskan di atas muncul karena di dalam Peraturan Pemerintah Nomor 11 Tahun 2010 tentang Penertiban dan Pendayaguna Tanah Terlantar, Peraturan Kepala Badan Pertanahan Nasional Republik Indonesia Nomor 4 Tahun 2010 tentang Tata Cara Penertiban Tanah Terlantar Jo. Peraturan Kepala Badan Pertanahan Nasional Republik Indonesia Nomor 9 Tahun 2011 tentang Perubahan Atas Peraturan Kepala Badan Pertanahan Nasional Republik Indonesia Nomor 4 Tahun 2010 Tentang Tata Cara Penertiban Tanah Terlantar sebagai peraturan teknis mengenai penertiban dan pendayagunaan tanah telantar belum mengakomodir prioritas-prioritas tanah yang seharusnya menjadi titik fokus pemerataan pemanfaatan dan penggunaan tanah. Peraturan ini hanya mengatur bahwa hak atas tanah dapat dilakukan identifikasi dan penelitian terhitung mulai 3 (tiga) tahun setelah Surat Keputusan Pemberian Hak atas Hak Milik, Hak Guna Usaha, Hak Guna Bangunan, dan Hak Pakai terbit atau tanah yang memperoleh izin/keputusan/surat dasar penguasaan atas tanah dari pejabat yang berwenang terhitung sejak berakhirnya dasar penguasaan tersebut. Oleh karena itu, minimnya skala prioritas penertiban dan pendayagunaan tanah terlantar sebagaimana yang telah dijelaskan menjadi persoalan normatif tersendiri, karena tentunya kebijakan pemantauan bermuara pada kebijaksanaan pemerintah yang berkuasa pada periode tertentu, maka secara empiris-praktis ketimpangan-ketimpangan penguasaan, enggunaan serta pemanfaatan tanah untuk meningkatkan ekonomi masyarakat masih akan tetap terjadi.

3) Peraturan Pemerintah Nomor 11 Tahun 2010 tentang Penertiban dan Pendayagunaan Tanah Terlantar, 
Peraturan Kepala Badan Pertanahan Nasional Republik Indonesia Nomor 4 Tahun 2010 tentang Tata Cara Penertiban Tanah Terlantar Jo. Peraturan Kepala Badan Pertanahan Nasional Republik Indonesia Nomor 9 Tahun 2011 tentang Perubahan Atas Peraturan Kepala Badan Pertanahan Nasional Republik Indonesia Nomor 4 Tahun 2010 Tentang Tata Cara Penertiban Tanah Terlantar sebagai peraturan teknis penertiban dan pendayagunaan tanah terantar sesungguhnya adalah amanat dari dari Pasal 6, Pasal 27, Pasal 34, dan Pasal 40 Undang-Undang Nomor 5 tahun 1960 tentang Peraturan Dasar Pokok-Pokok Agraria yang menyatakan bahwa semua hak atas tanah mempunyai fungsi sosial, apabila tanah meski dilekatkan dengan hak atas tanah sebagaimana di atur di dalam Undang-Undang tidak dilakukan penggunaan dan pemanfaatan sesuai dengan peruntukan pemberian haknya, maka tanah tersebut dikategorikan sebagai tanah terlantar yang dapat dilakukan penghapusan atas haknya. Akan tetapi peraturan teknis tersebut belum mengkomodir hal-hal sebagai berikut:

a) Tata-tata cara permohonan pengeluaran dari basis data (data base) tanah terindikasi terlantar Kementerian Agraria dan Tata Ruang/Badan Pertanahan Nasional oleh pemegang hak atas tanah;

b) Penyelesaian sengketa, konflik, atau perkara yang berkaitan dengan tanah terlantar oleh pemegang hak atas tanah;

c) Ketidakjelasan bagaimana kedudukan kreditur jaminan hak tanggungan terhadap tanah yang ditetapkan sebagai tanah terlantar;

d) Upaya hukum yang dapat dilakukan oleh pemegang hak atas tanah jika tanah tersebut 
masuk dalam prosedur identifikasi dan penelitian hingga dengan penetapan tanah terlantar;

e) Belum adanya pengakuan atas penertiban dan pendayagunaan tanah terlantar yang dilakukan oleh Pemerintah Masyarakat Hukum Adat;

f) Belum adanya wadah untuk masyarakat ikut berperan dalam pelaksanaan penertiban tanah dan pendayagunaan terlantar.

Peraturan teknis yang belum lengkap ini menjadi persoalan tersendiri dari sisi perlindungan hukum. Perlindungan hukum yang menurut Sudikno Mertokusumo adalah suatu perbuatan yang melindungi subjek-subjek hukum dengan peraturan perundang-undangan yang berlaku dan pelaksanaannya, dapat dipaksakan dengan suatu sanksi yang dapat juga diartikan sebagai segala upaya hukum yang menjamin adanya kepastian hukum untuk memberikan perlindungan kepada masyarakat umum menjadi tidak terpenuhi dalam lalu lintas politik hukum penertiban tanah dan pendayagunaan terlantar di Indonesia. ${ }^{193}$

C. Alternatif Politik Hukum Penertiban dan Pendayagunaan Tanah Terlantar di Masa Depan Dalam Rangka Mengurangi Dampak Negatif Dari Pengaturan Penertiban Dan Pendayagunaan Tanah Terlantar Saat Ini

Untuk mengurangi atau bahkan meniadakan dampak negatif dari politik hukum Pengaturan dan Prosedur Hukum Penertiban dan Pendayagunaan Tanah Terlantar yang ada, maka perlu pemikiran untuk mengembangkan politik hukum pertanahan yang "prismatik". Arah politik hukum pertanahan prismatik ini dimaksudkan untuk mewujudkan dan mendorong kemajuan perekonomian Indonesia melalui penataan penguasaan dan pemanfaatan tanah namun tetap memberikan perhatian terhadap kelompok yang lemah secara

193 Eli Wuria Dewi, Hukum Perlindungan Konsumen, (Yogyakarta, Graha Ilmu, 2015) hlm. 30. 
sosial-ekonomi-politik dengan memberikan akses kepada mereka mempunyai tanah. Untuk mewujudkan tujuan tersebut, politik hukum pertanahan prismatik mendasarkan pada prinsip hukum tertentu sebagai dasar pengembangan kebijakan pertanahan, yaitu: ${ }^{194}$

1. Prinsip keberagaman hukum dalam kesatuan;

Prinsip ini menekankan pada penghormatan terhadap perbedaan hukum yang terdapat di bidang pertanahan khususnya dengan memberikan pengakuan dan penghormatan terhadap kewenangan pemerintah masyarakat hukum adat sebagaimana dikehendaki oleh Pasal 18B ayat (2) Undang-Undang Dasar Negara Republik Indonesia Tahun 1945. Namun pengakuan tersebut harus sesuai dengan kepentingan bangsa dan negara sebagai konsekuensi dari komitmen kebangsaan yang sudah disepakati. Ketika hal ini dapat diakomodir dalam politik hukum penertiban dan pendayagunaan tanah terlantar di Indonesia, maka dapat dikatakan bahwa penggunaan dan pemanfaatan tanah dapat dilakukan dengan optimal karena sebagian besar negara Indonesia adalah masyarakat hukum adat.

2. Prinsip persamaan atas dasar ketidaksamaan;

Prinsip ini menekankan bahwa untuk mewujudkan adanya persamaan secara sosial ekonomi terutama di Indonesia harus dikembangkan kebijakan pertanahan yang merdasarkan pada realita kesamaan (perbedaan) di antara kelompok-kelompok masyarakat. Bagi kelompok yang lemah harus ada intervensi negara untuk memberikan kemudahan dan fasilitas pemberian tanah. Dengan adanya perbedaan perlakuan tersebut, semua kelompok akan mencapai persamaan kondisi sosial ekonomi.

194 Nurhasan Ismail, Arah Politik Hukum Pertanahan dan Perlindungan...op.cit., hlm. 48. 
3. Prinsip mengutamakan keadilan dan kemanfaatan di atas kepastian hukum;

Prinsip ini menekankan bahwa mewujudkan pemerataan penguasaan dan pemilikan tanah merupakan kebijakan yang lebih memenuhi rasa keadilan dan kemanfaatan bagi masyarakat. Berdasarkan prinsip ini, menumpuk penguasaan dan pemanfaatan tanah merupakan tindakan yang tidak adil dan tidak bermanfaat karena hanya menimbulkan kecemburuan sosial dan penelantaran tanah yang merugikan kepentingan bersama.

Hal ini sejalan dengan teori tujuan hukum yang dikemukakan oleh Gustav Radburch bahwa tujuan hukum itu tidak hanya menciptakan kepastian terhadap hukum itu sendiri dalam artian hanya melihat bunyi-bunyi pasal yang dikenakan, melainkan juga harus menciptakan rasa keadilan dan kemanfaatan bagi masyarakat. ${ }^{195}$

4. Prinsip diferensiasi fungsi dalam keterpaduan;

Prinsip ini menekankan bahwa di satu sisi pembagian kewenangan di antara instansi pemerintah merupakan suatu kebutuhan untuk terjadinya efektivitas pencapian tujuan bersama. Oleh karenya harus dicegah tejadinya egoisme sektoral yang menyebabkan terjadinya hambatan terhadap pencapaian tujuan bersama. Untuk itu, keterpaduan di antara instansi pemerintah menjadi keniscayaan agar kebijakan yang dikembangkan tidak saling tumpang tindih dan saling menafikan.

5. Prinsip penggerakan peran masyarakat

Prinsip ini menenakan bahwa dalam era demokratisasi, transparansi dan era penegakan hak-hak

195 Satria Sukananda dan Chrisinta Dewi Destiana, Evaluasi Penegakan Hukum Tindak Pidana Korupsi Oleh Komisi Pemberantasan Korupsi (KPK) dalam Perspektif Sosiologi Hukum, Jurnal Peradilan Indonesia Teropong, Volume 7, Juli Desember (2019) lihat juga Satria Sukananda, et al., Sosiologi Hukum Kontemporer Analisis Kritis Terhadap Penegakan Hukum di Indonesia, (Yogyakarta: Litera, 2018) hlm. 106. 
asasi manusia, serta dalam menuju pemerintahan yang bersih, maka keterlibatan masyarakat di semua sektor pembangunan sangat diperlukan. ${ }^{196}$ Masyarakat secara kelompok maupun sendiri-sendiri dapat memberikan laporan terhadap adanya tanah-tanah yang diperkirakan ditelantarkan oleh para pemegang haknya untuk dilakukan idenfitikasi. Terhadap tanah tersebut, masyarakat dapat mengusulkan pemanfaatan tanah dimaksud sesuai peraturan perundang-undangan yang berlaku dengan memperhatikan kebutuhan dan kondisi setempat.

\section{Penutup}

Arah politik hukum Pengaturan dan Prosedur Hukum Penertiban dan Pendayagunaan Tanah Terlantar di Indonesia pada awalnya adalah untuk menjamin terwujudnya kemakmuran bagi seluruh rakyat indonesia. Untuk mewujudkan tujuan tersebut, Undang-Undang Nomor 5 Tahun 1960 tentang Peraturan Dasar Pokok-Pokok Agraria (UUPA) mengandung prinsip-prinsip penguasaan dan pemanfaatan tanah untuk mendorong kemajuan, industri, dan bidang lain yang pelaksanaanya tergantung pada ketersediaan tanah. Oleh karena itu untuk melaksanakan prinsip-prinsip tersebut diterbitkan Peraturan Pemerintah Nomor 11 Tahun 2010 tentang Penertiban dan Pendayagunaan Tanah Terlantar, Peraturan Pemerintah tersebut maka diterbitkan Peraturan Kepala Badan Pertanahan Nasional Republik Indonesia Nomor 4 Tahun 2010 tentang Tata Cara Penertiban Tanah Terlantar Jo. Peraturan Kepala Badan Pertanahan Nasional Republik Indonesia Nomor 9 Tahun 2011 tentang Perubahan Atas Peraturan Kepala Badan Pertanahan Nasional Republik Indonesia Nomor 4 Tahun 2010 Tentang Tata Cara Penertiban Tanah Terlantar dan Peraturan Kepala Badan Pertanahan Nasional Republik Indonesia Nomor 5 Tahun 2011 tentang Tata

196 Satria Sukananda, Tanggung Jawab Sosial Perusahaan (Studi Tentang Pengawasan dan Pertanggungjawaban Pelaksanaan Ketentuan Corporate Social Responsibility di Indonesia), (Banyumas: Pena Persada, 2020) hlm. 120, 
Cara Pendayagunaan Tanah Negara Bekas Tanah Terlantar. Namun demikian, pengaturan hukum penertiban dan pendayagunaan tanah terlantar di Indonesia saat ini masih memiliki dampak negatif politik hukum optimalisasi penggunaan dan pemanfaatan tanah di Indonesia.

Beberapa dampak politik hukum terhadap optimalisasi penggunaan dan pemanfaatan tanah di indonesia adalah:

1. Konflik kewenangan antarinstansi pemerintah yang terkait dengan penertiban dan pendayagunaan tanah terlantar, instansinya yaitu Kementerian Agraria dan Tata Ruang/Badan Pertanahan Nasional, Kementerian Kehutanan, Kementerian Pertanian dan Kementerian Terkait lainnya. Konflik kewenangan antar instansi pemerintah yang terkait dengan penertiban dan pendayaguanaan tanah terlantar, instansinya yaitu Kementerian Agraria dan Tata Ruang/Badan Pertanahan Nasional, Kementerian Kehutanan, Kementerian Pertanian, dan kementerian terkait lainnya. Sumber konfliknya adalah berdasarkan pengaturan hukum penertiban dan pendayagunaan tanah terlantar yang ada saat ini mengatur salah satu objek yang dapat dilakukan identifikasi dan penelitian terhadap tanah terindikasi terlantar adalah Dasar Penguasaan Atas Tanah (DPAT) yang selanjutnya dapat berbentuk izin/keputusan/surat dari pejabat yang berwenang yang menjadi dasar bagi orang atau badan hukum untuk menguasai, menggunakan, atau memanfaatkan tanah, dapat berupa izin Lokasi dan Pelepasan Kawasan Hutan. Di satu pihak terdapat produk hukum di luar Hak Atas Tanah yang diterbitkan oleh Kementerian terkait sedangkan yang dapat melakukan identifikasi dan penelitian hingga penetapan tanah telantar adalah Kementerian Agraria dan Tata Ruang/Badan Pertanahan Nasional yang sudah jelas Dasar Penguasaan Atas Tanah (DPAT) bukan merupakan produk hukumnya. Secara normatif yuridis, ketentuan hukum ini menimbulkan konfilik horizontal antarlembaga Kementerian. 
2. Terjadinya kesenjangan dalam penguasaan dan pemanfaatan sumber daya alam berupa tanah. Ada sekelompok kecil subyek menguasai dan memanfaatkan tanah yang sangat luas/besar, namun sebagian besar warga masyarakat hanya menguasai memanfaatkan bagian sumber daya yang relatif terbatas. hal ini dikarenakan di dalam pengaturan penertiban dan pendayagunaan tanah terlantar saat ini belum mengakomodir prioritas-prioritas tanah yang seharusnya menjadi titik fokus pemerataan pemanfaatan dan penggunaan tanah. Peraturan ini hanya mengatur bahwa hak atas tanah dapat dilakukan identifikasi dan penelitian terhitung mulai 3 (tiga) tahun setelah Surat Keputusan Pemberian Hak atas Hak Milik, Hak Guna Usaha, Hak Guna Bangunan, dan Hak Pakai terbit atau tanah yang memperoleh izin/keputusan/surat dasar penguasaan atas tanah dari pejabat yang berwenang terhitung sejak berakhirnya dasar penguasaan tersebut. Oleh karena itu, minimnya skala prioritas penertiban dan pendayagunaan tanah terlantar sebagaimana yang telah dijelaskan menjadi persoalan normatif tersendiri, karena tentunya kebijakan pemantauan bermuara kebijaksanaan pemerintah yang berkuasa pada periode tertentu, maka secara empiris-praktis ketimpangan-ketimpangan penguasaan, penggunaan serta pemanfaatan tanah untuk meningkatkan ekonomi masyarakat masih akan tetap terjadi.

3. Pengaturan penertiban dan pendayagunaan tanah terlantar saat ini memang bertujuan menjalankan amanat dari Pasal 6, Pasal 27, Pasal 34, dan Pasal 40 Undang-Undang Nomor 5 tahun 1960 tentang Peraturan Dasar Pokok-Pokok Agraria yang menyatakan bahwa semua hak atas tanah mempunyai fungsi sosial, apabila tanah meski dilekatkan dengan hak atas tanah sebagaimana diatur di dalam undang-undang tidak dilakukan penggunaan dan pemanfaatan sesuai dengan peruntukan pemberian haknya, maka tanah tersebut dikategorikan sebagai tanah terlantar yang dapat dilakukan 
penghapusan atas haknya. Akan tetapi peraturan teknis tersebut belum mengkomodir hal-hal sebagai berikut:

a. Tata-tata cara permohonan pengeluaran dari basis data (data base) tanah terindikasi terlantar Kementerian Agraria dan Tata Ruang/Badan Pertanahan Nasional oleh pemegang hak atas tanah;

b. Penyelesaian sengketa, konflik atau perkara yang berkaitan dengan tanah terlantar oleh pemegang hak atas tanah;

c. Ketidakjelasan bagaimana kedudukan kreditur jaminan hak tanggungan terhadap tanah yang ditetapkan sebagai tanah terlantar;

d. Upaya hukum yang dapat dilakukan oleh pemegang hak atas tanah jika tanah tersebut masuk dalam prosedur identifikasi dan penelitian hingga dengan penetapan tanah terlantar;

e. Belum adanya pengakuan atas penertiban dan pendayagunaan tanah terlantar yang dilakukan oleh Pemerintah Masyarakat Hukum Adat;

f. Belum adanya wadah untuk masyarakat ikut berperan dalam pelaksanaan penertiban tanah dan pendayagunaan terlantar.

Alternatif yang ditawarkan untuk mengurangi atau bahkan meniadakan dampak negatif dari politik hukum pengaturan dan prosedur hukum penertiban dan pendayagunaan tanah terlantar di Indonesia adalah mengembangkan politik hukum pertanahan yang "prismatik" dengan bersandar pada prinsip keberagaman hukum dan kesatuan; prinsip persamaan atas dasar ketidaksamaan; prinsip mengutamakan keadilan dan kemanfaatan di atas kepastian hukum; prinsip diferensiasi fungsi keterpaduan; dan prinsip penggerakan peran masyarakat. 


\section{Daftar Pustaka}

\section{Buku}

Arnowo, Waskito. d. (2018). Pertanahan, Agraria dan Tata Ruang. Jakarta: Kencana Prenada Media Group.

Dewi, E. W. (2015). Hukum Perlindungan Konsumen. Yogyakarta: Graha Ilmu.

Direktorat Penertiban dan Pendayagunaan Tanah Terlantar \& Direktorat Jenderal Pengendalian Pemanfaatan Ruang dan Penguasaan Tanah Kementerian Agraria dan Tata Ruang/Badan Pertanahan Nasional (2018). Petunjuk Teknis Pendayagunaan Tanah Terlantar 2018. Jakarta: Kementerian Agraria dan Tata Ruang/Badan Pertanahan Nasional.

Direktorat Penertiban dan Pendayagunaan Tanah Terlantar \& Direktorat Jenderal Pengendalian Pemanfaatan Ruang dan Penguasaan Tanah Kementerian Agraria dan Tata Ruang/ Badan Pertanahan Nasional (2019). Petunjuk Teknis Pendayagunaan Tanah Terlantar 2019 Jakarta: Kementerian Agraria dan Tata Ruang/Badan Pertanahan Nasional.

Indonessia, Departemen. Penerangan. (1982). Pertanahan Dalam Era Pembangunan Nasional. Jakarta: Ditjen Agraria Departemen Dalam Negeri.

Manan, Abdul. (2016). Politik Hukum Studi Perbandingan dalam Pratik Ketatanegaraan Islam dan Sistem Hukum Barat. Jakarta: Prenada Media Group.

McAusian, P. (1986). Tanah Perkotaan dan Perlindungan Rakyat Jelata. Jakarta: PT. Gramedia.

MD, Mahfud. Moh. (2011). Membangun Politik Hukum Menegakkan Konstitusi. Jakarta: Raja Grafindo Persada. 
MD, Mahfud. Moh. (2012). Politik Hukum di Indonesia. Jakarta: Raja Grafindo Persada.

Satria Sukananda, et.al. (2018). Sosiologi Hukum Kontemporer Analisis Kritis Terhadap Penegakan Hukum di Indonesia. Yogyakarta: Litera.

Statistik, Berita. Resmi. (2010). Profil Kemiskinan di Indonesia 2010, dalam Berita Statistik No.45/07/th XIII,. Jakarta: Badan Pusat Statistik 1 Juli 2010.

Sukananda, Satria. (2020). Tanggung Jawab Sosial Perusahaan (Studi Tentang Pengawasan dan Pertanggungjawaban Pelaksanaan Ketentuan Corporate Social Responsibility di Indonesia. Banyumas: Pena Persada.

Wahjono, P. (1986). Indonesia Negara Berdasarkan Atas Hukum cet II. Jakarta: Ghalia Indonesia.

\section{Jurnal \& Prosiding}

Ismail, Nurhasan. (April 2020). Arah Politik Hukum Pertanahan dan Perlindungan Kepemilikan Tanah Masyarkat (Political Direction of Land Law and Protection of People's Land Ownership. Jurnal Rechtvinding Media Pembinaan Hukum Nasional, Volume 1 Nomor1.

Satria Sukananda, Chrisinta Dewi Destiana. (Volume 7, Juli-Desember (2019)). Evaluasi Penegakan Hukum Tindak Pidana Korupsi Oleh Komisi Pemberantasan Korupsi (KPK) dalam Perspektif Sosiologi Hukum. Jurnal Peradilan Indonesia Teropong.

Zulfadhli, H, Tanah Untuk Petani, tulisan yang disampaikan dalam Seminar Nasional HKTI "Reforma Agraria, Pelaksanaan Otonomi Daeran, dan Penataan Ruang, 2009; lihat juga Iwan N. Selamat, Ketimpangan Struktur Agraria Indonesia, 2009 
Sahna, M. Y. (Desember 2015). Penerapan Prinsip Keadilan dalam Pembebasan Tanah Bagi Pembangunan untuk Kepentingan Umum. Jurnal Ius (Kajian Hukum dan Keadilan) Vol. 3 No.9, 422.

Saripudin. (2015 ). Konsep Penertiban dan Pendayagunaan Tanah Terlantar Dalam Perspektif Reforma Agraria. Jurnal Ilmu Hukum Vol. 11, No. 22, hlm 110-153.

Ulya, Z. ((Oktober - Desember 2016)). Ekspetasi Pengelolaan Tanah Terlantar oleh Baitul Mal Dalam Peningkatan Kesejahteraan Masyarakat. Jurnal Hukum dan Pembangunan Vol. 46 No. 4, 509.

\section{Internet \& Artikel Cetak}

Eko Budihardjo, Metropolis atau Miseropolis, dalam Kompas, Jakarta, Sabtu 22 September 2007.

Satria Sukananda, Arti Penting Pendaftaran Tanah, https://metrojambi.com/read/2019/05/21/43755/arti-pe nting-pendaftaran-tanah,webugm@ugm.ac.id, Ketimpangan Kepemilikan Aset Sebagai Penyebab Kemiskinan, (Yogyakarta: Universitas Gadjah Mada, 2008)

Lucinda, Di Tengah Kepungan Bisnis Ritel, dalam Harian Bernas, Yogyakarta, tanggal 18 Mei 2010

Khudori, Petani Kemisikan, dan Reforma Agraria, dalam Kompas, Jakarta, 16 Maret 2007.

NN, Palm Oil Problem: Plantation Companies in Conflict With Villagers, Tuesday, May, 19th, dalam Jakarta Post, Jakarta, 2009

Kompas, Tanah Perkotaan dan Perlindungan Rakyat Jelata, Tajuk Rencana, 2008. 
Kompas, 2011, Kemiskinan Tampak Nyata, Senin, 15 Agustus, hlm. 15. 
POLITIK HUKUM ZAKAT, WAKAF, DAN EKONOMI

SYARI'AH

\section{Fatma Hidayati}

Alumni Program Magister Ilmu Hukum Universitas Islam Indonesia

Email: hidayatifatma@gmail.com

\section{A. Pendahuluan}

Indonesia dalam lingkungan dunia Islam merupakan fenomena ke Islaman tersendiri yang mempunyai perbedaan dengan dunia Islam lain, baik dari sisi kenegaran maupun kondisi masyarakat. karenanya, para peneliti dunia islam merasa belum lengkap jika tidak mentertakan Indonesia dalam proyek penelitiannya. Selain Indonesia berpendudukan muslim terbesar di Dunia, juga karena di tengah-tengah kehidupan mayoritas muslim ini, segala persoalan kenegaraan, lebangsaan, dan kemasyarakatannya tidak dilandaskan kepada suatu paham kegamaan (keislaman). Justru, yang dijadikan pandangan hidup (way of life) adalah ideologi negara yaitu Pancasila, sejumlah nilai dasar yang digali dari bumi Indonesia sendiri yang pada tingkat tertentu bisa menjadi "titik temu" antar golongan masyarakat Indonesia.

Di dalam tatanan negara hukum (rechtstaat) yang berdasar Pancasila ini, masyarakat Muslim Indoensia mengamalkan sebagian hukum ajaran agamanya dan sebagian yang lain harus tunduk kepada "hukum negara" yang diadopsi dari Barat. Tentu saja secara simplistis dapat diasumsikan bahwa sepanjang sejarahnya, perjuangan penegakan Syri'at Islam di wilayah negara Pancasila ini senantiasa mengalami masa-masa ketegangan (tension) dan berganing of power yang cukup melelahkan, baik dalam eleman bangsa yang lain maupun dengan negara. Dialektika Syari'at Islam dengan kekuasaan politik negara Pancasila pun tak pelak lagi terjadi terus menerus. Pada wilayah inilah politik hukum suatu negara 
memegang peranan penting -bahkan kadang menghegemoni-dalam menentukan pemberlakukan Syari'at Islam. Perjuangan memformalkan Syari'at Islam melalui jalur konstitusional di Indonesia sebagian mengalami kesuksesan. Sebagai contoh, berbagai peraturan perundang-undangan yang telah diterbitkan antara lain Undang-Undang Nomor 1 Tahun 1974 tentang Perkawinan, Undang-Undang Nomor 7 Tahun 1989 tentang Pengadilan Agama, Intruksi Presiden Nomor 1 Tahun 1991 tentang Penyebarluasan Kompilasi Hukum Islam (KHI), Undang-Undang Nomor 13 Tahun 2008 tentang penyelenggraan Ibadah Haji, Undang-Undang Nomor 23 Tahun 2011 tentang Pengelolaan Zakat, Undang-Undang Nomor 10 Tahun 1998 tentang Perbangkan, Undang-Undang Nomor 11 Tahun 2006 tentang Pemerintahan Aceh, dan lain-lain.

Perkembangan ini terjadi sebagai jaminan bahwa reformasi Islam bekerja melalui birokrasi administrasi. Para ulama memegang posisi penting dalam ketatanegaraan yang berhubungan dengan masalah agama yang secara resmi bekerja di kantor pengadilan agama. Tokoh agama juga berkerja sebagai konsultan hukum Islam dalam lembaga zakat dan wakaf. Mekanisme pengorganisasian praktik Syariah di dalam struktur sistem negara tidak dapat dihindarai karena berhubungan dengan masalah publik. ${ }^{197}$ Berdasarkan uraian sebelumnya penulis akan mengerucutkan pembahasan pada politik hukum Zakat, wakaf dan Ekonomi Syari'ah. Yang mana dalam pembahasannya akan banyak membahas sejarah formalisasi Syari'at Islam yang berkaitan erat dengan diundangkannya peraturan berkenaan dengan Zakat, Wakaf dan Ekonomi Syariah.

197 Muhammad Qasim Zaman, The Ulama in Contemporary Islam: Custodians of Change, (Princeton: Princeton Univ. Press), hlm. 2 


\section{B. Regulasi Zakat, Wakaf dan Ekonomi Syari'ah}

\section{Formalisasi Syari'at Islam di Era Orde Lama}

Sikap Akomodasi masyarkat Islam khususnya Nahdlatul Ulama terhadap kekuasaan Soekarno atau dalam bahasa Deliar Noer, "Politik penyesuaian diri" dalam bidang politik praktis berbeda bila bersinggugan denagn keyakinan agama. Terlihat dengan tampilan NU sebagai penentang Partai Komuni Indonesia dengan menandinginya dalam semua aspek kehidupan. Kolaborasi NU dengan pemerintahan Soekarno berlangsung sampai runtuhnya Demokrasi Terpimpin. Kehancuran Demokrasi Terpimpin terjadi setalah terjadinya kudeta yang gagal oleh Gerakan 30 S (yang diduga didalangi oleh PKI) pada 1965. Konfigurasi politik pada era ini dikualifasikan sebagai otoriter di tangan Presiden Soekarno, jika dilihat dari bekerjanya pilar-pilar demokrasi, kekuasaan partai-partai dan parlemen sangat lemah sebaliknya kekuasaan Presiden sangat kuat. Sikap akomondasi yang dilakukan oleh tokoh-tokoh Islam saat itu menghasilkan beberapa formalisasi Islam di Era Orda Lama berupa:

a. Pembentukan Kementrian Agama; 198

b. Pengelolaan Peradilan Agama; ${ }^{199}$

c. Undang-Undang Pencatatan Nikah, Talak, dan Rujuk;200

d. Undang-undang Pencegahan Penyalahgunaan dan/atau Penodaan Agama 1965. ${ }^{201}$

Di era Orde lama ini Pancasila sebagai dasar konstitusi negara dalam mengawasi praktik agama di Indonesia. Kementerian Agama mengimplementasikan hlm. 13-14.

199 D.S. Lev, Peradilan Agama Islam di Indonesia: Suatu Studi tentang Landasan Politik Lembaga-lembaga Hukum, alih bahasa Zaini Ahmad Noeh, (Jakarta: Intermasa, 1980), hlm. 85-86.

200 Achmad Gunaryo, Pergumulan Politik dan Hukum Islam: Reposisi Peradilan Agama dari peradilan "Pupuk Bawang" Menuju Peradilan yang Sesungguhnya. (Yogyakarta: Pustaka Pelajar, 2006), hlm. 105-106

201 Ibid. 106-107 
birokratisasi Islam dan agama lainnya di Indonesia. Penggabungan Syariah ke dalam sistem birokrasi adalah manifestasi bagi negara. Keterlibatan negara dalam administrasi bukanlah bertujuan untuk mengendalikan atau membatasi urusan beragama, melainkan untuk mengelola hubungan sosial beragama sesuai denagn konstitusi negara. Departemen Agama memiliki fungsi mengimplementasikan kebijakan pemerintah tentang agama demi kepentingan yang lebih luar biasa untuk memelihara persatuan nasional. 202 Oleh karena itu, departemen agama mengorganisasi Islam dan Agama-agama lain sebagai badan administrasi pusat.

\section{Formalisasi Syari'at Islam di Era Orde Baru}

Pemerintah Orde Baru Awalnya berlanggam libertarian yang sebenarnya adalah langgam tansisi untuk mencari format tetap politik Orde Baru. Sejak Orde Baru dimulai, Indonesia mengalami kembali konfigurasi politik otoriter yang birokratis. Program pembangunan nasional yang menitikberatkan pada ekonomi harus diamankan dengan stabilitas nasional sebagai prasyaratnya. ${ }^{203}$ Format politik Orde Baru yang dibentuk tahun 1966 menempatkan militer sebagai kekuatan politik dominan. Persoalan utama yang dihadapi pemerintah Orde Baru saat itu adalah krisis dari razim sebelumnya, berupa krisis ekonomi dan politik. Untuk mengatasi krisis ini pemerintah mengambil kebijakan berupa pembangunan ekonomi yang berorientasi keluar dan kebijakan politik yang mendukung pembangunan ekonomi. ${ }^{204}$

Konfigurasi politik di Era Orde Baru tidak bisa disebut demokratis dikarenakan dominannya peran Golkar

202 Asep Saepudin Jahar, Bureaucratizing Sharia In Modern Indonesia: The Case Of Zakat, Waqaf And Family Law, (Jakarta: Studia Islamika: Indonesia Jornal For Islam Studies, 2019), hlm 111-114

203 Moh. Mahfud MD, Politik Hukum di Indonesia, (Jakarta: RajaGrafindo Persada, 2012), hlm. 195.

204 Abdul Aziz Taba, Islam dan Negara dalam Politik Orde Baru, (Jakarta: Gema Insani Press, 1996), hlm. 168-187 
sebagai partai pemerintah dan lemahnya kontestasi politik di antara partai-partai politik yang ada. Masa Orde Baru hubungan antara Islam dan Negara mengalami metamorfosis. Pada awalnya, hubungan mereka bersifat antagonistik (1966-1981), kemudian berubah menjadi resiprokal kritis (1982-1985). Sejak tahun 1985, hubungan di antara keduanya berpola akomodatif. ${ }^{205}$ Beberapa fenomena yang menandai hubungan akomodatif Islam dan negara adalah: pertama, keluarnya kebijakan pemerintah untuk menghapus larangan berbusana muslimah (jilbab) disekolah-sekolah; kedua, pengesahan Rancangan Undang-Undang Peradilan Agama; ketiga, Pengirimanan Dai ke daerah-daerah transmigran; empat, pendirian Bank Muamalat, Sosialisasi Kompilasi Hukum Islam (KHI) dan lainnya yang menyangkut kegiatan keagamaan khususnya Islam. 206

Pemerintahan Orde Baru melakukan formalisasi beberapa aspek hukum Islam menjadi hukum negara. Penerapan Syari'at Islam sangat tergantung dengan restu pada pemerintah yang sangat berkuasa. Adapun beberapa penerapannya adalah:

a. Undang-Undang Pendidikan Nasional, dalam rangka memperluas sosialisasi nilai-nilai Islam, kaum Muslim berharap agar mata pelajaran agama juga dimasukan ke dalam kurikulum sekolah-sekolah negeri maupun swasta yang berada di bawah pengawasan Departemen Pendidikan dan Kebudayaan.tahun 1950, melalui Undang-Undang Nomor 4 Tahun 1950 memutuskan pembelajaran agama diberikan disemua sekolah negeri 207 meskipun ada beberapa Pasal menimbulkan polemik.sehingga mengharuskan dikeluarkannya Ketetapan MPR No XXVII/MPRS/1966 tentang Agma dan Ketatapan MPRS No II/ MPRs/1960.

205 Ibid., hlm. 239-240.

206 Ibid., hlm. 262-266.

207 Undang-undang No. 4 Tahun 1950 Tentang Dasar-dasar Pendidikan dan Pengadjaran di sekolah. 
b. Kompilasi Hukum Islam (Intruksi Presiden Nomor 1 Tahun 1991) guna melengkapi Pengadilan Agama dengan acuan hukum yang terpadu, negara mendukung upaya Kompilasi Hukum Islam (KHI) yang telah selesai tahun 1991. KHI ini isinya berkaitan dengan perkawinan, warisan dan wakaf, yang berfungsi sebagai acuan hukum yang tunggal dalam pengadilan agama. ${ }^{208}$ Bagi Departemen Agama maupun hakim-hakim Pengadilan Agama, secara politisi, intruksi pemberlakuan KHI memiliki arti penting. Tujuan jangka panjang Inpres No 1 Tahun 1991 tentang KHI dan SK Menteri Agama No 154 Tahun 1991 adalah menjadikan hukum Islam semakin mengakar di masyarakat.

Pada rezim Orde Baru, Suharto menanggapi usulan penyelenggaran administrasi zakat dengan mengeluarkan Keputusan Presiden Nomor 07/PRIN/1968 pada tanggal 31 Oktober 1968. 209 Inisiatif Presiden ini tidak bertujuan mendukung implementasi Syari'at tetapi untuk tujuan politiknya mendapatkan dukungan komunitas Islam selama fase awal kepresidenan. Razim Orde Baru di awal kepemimpinannya enggan melegalkan administrasi zakat dalam lembaga pemerintahan. Namun, Soeharto juga tidak membatasi atau mengintruksikan Departemen Agama untuk mnegatur zakat. Kementrian Urusan Agama misalnya diizinkan untuk mengumpulkan dana dari muslim yang merupakan Pegawai Negeri Sipil pada tahun 1984 untuk tujuan kesejahteraan sosial. Berkenaan dengan administrasi zakat departemen Agama mengeluarkan intruksi Nomor 16/1989 yang berkaitan dengan zakat, infak, dan shadaqah yang berlaku hingga hirarki terendah yaitu Kantor Urusan Agama di tingkat kecamatan.

208 Bahtiar Effendy, Islam dan Negara: Transformasi Gagasan dan Praktik Politik Islam di Indonesia, (Jakarta: Democracy Project-Yayasan Abad Demokrasi, 2011), hlm. 339-340.

209 Cholid Fadlullah, Mengenal Hukum Hukum ZIS (Zakat, Infaq/Sedekah) dan Pengalamannya di DKI Jakarta, (Jakarta: BAZIS DKI Jakarta), hlm. 94. 
Sejak Indonesia merdeka, di beberapa daerah di tanah air, pejabat-pejabat pemerintah yang menjadi penyelenggara negara telah ikut serta membantu pemungutan dan pendayagunaan zakat. Sebagai langkah konkret, pemerintah mengeluarkan Peraturan Menteri Agama Nomor 4 tahun 1968 tentang Pembentukan Badan Amil Zakat dan Peraturan Menteri Agama Nomor 5 Tahun 1968 tentang pembentukan baitul mal di tingkat Pusat, provinsi, dan Kabupaten/Kotamadya. Seharusnya pada tahun 1967 pemerintah telah menyiapkan RUU Zakat yang diajukan ke DPR Gotong Royong dengan harapan akan mendapat dukungan dari Menteri Sosial dan Menteri Keuangan. Namun Menteri Keuangan berpendapat bahwa peraturan zakat tidak perlu dibuat dalam bentuk Undang-undang melainkan cukup dengan Peraturan Menteri. Atas pertimbangan itu, intruksi Menteri Agama Nomor 1 Tahun 1970 keluar yang menunda pelaksanaan Peraturan Menteri Agama Nomor 4 dan 5 Tahun 1968. Perhatian pemerintah terhadap pelaksanaan zakat terjadi pada masa orde baru, yang diaktualisasikan dengan anjuran Presiden Soeharto untuk melaksanakan zakat secara efektif dan efisien serta mengembangkannya dengan cara-cara yang lebih luas dengan pengarahan yang lebih tepat. Saat itu, Presiden mengumumkan kepada seluruh umat Islam Indonesia bahwa secara pribadi dia bersedia untuk mnegurus pengumpulan zakat secara besar-besaran sebagai amil zakat. 210

Anjuran tersebut mendorong terbentuknya badan amil zakat diberbagai provinsi yang dipelopori oleh Pemerintah Daerah DKI Jakarta. Pembentukan Amil Zakat ini kemudian diikuti oleh daerah lain denagn dukungan pemerintah setempat dan ulama. ${ }^{211}$ Pada Tahun 1991 Surat Keputusan Bersama Menteri Agama dan Menteri Dalam

210 M Dawam Rahardjo, "Zakat dalam Prespektif Sosial Ekonomi," dalam Pesantren nomor 2/vol. III/1986, hlm. 40.

211 Sahid HM., Legislasi Hukum Islam di Indonesia: Studi Formalisasi Syariat Islam, (Surabaya: Pustaka Idea, 2016), hlm. 118-119 
Negeri Nomor 29 dan 47 Tahun 1991 tentang Pembinaan Amil Zakat, Infak, dan Sedekah (BAZIS) keluar. BAZIS ini dibentuk mulai dari tingkat pusat, provinsi, kabupaten/kotamadya, kecamatan sampai tingkat desa/kelurahan. Program ini disambut baik oleh umat Islam karena membantu umat Islam dalam pengelolaan zakat melalui kelembagaan yang lebih representatif, memiliki kemampuan manajerial, dan berada di bawah pembinaan dan pengawasan pemerintah agar harta zakat lebih berfungsi untuk pengentasan kemiskinan dalam rangka pemberdayaan umat. ${ }^{212}$

Pada tahun 1991, perjanjian kerjasama antara Kementrian Dalam Negeri dan Departemen Agama menyebabkan Penertiban bersama surat Nomor 29 dan 47/ 1991 tentang Bantuan dalam Organisasi zakat. Perjanjian bersama ini ditindaklanjuti oleh Departemen Agama dengan intrusi Nomor 5/1998 dengan intruksi yang sama. aturan zakat ini tidak dimaksudkan untuk memfasilitasi urusan keagamaan khususnya Islam dalam administrasi zakat, tetapi lebih berusaha untuk meningkatkan dukungan politik Muslim dan memperkuat razim Orde Baru. ${ }^{213}$

\section{Syari'at Islam di Indonesia dalam Kekuasaan Politik Pemerintah Era Reformasi}

Krisis finansial Asia yang menyebabkan ekonomi Indoensia melemah dan semakin besarnya ketidakpuasan masyarakat Indonesia terhadap pemerintahan Soeharto yang tidak demokrasi menyebabkan terjadinya demontrasi besar-besaran yang dilakukan berbagai organ aksi mahasiswa di berbagai wilayah Indonesia menuntut reformasi di segala bidang. Konfigurasi Politik pada era Reformasi dikualifikasikan sebagai konfigurasi politik yang demokratis. Jika dilihat dari bekerjanya pilar-pilar

212 Ibid., hlm 120.

213 Asep Saepudin Jahar, The Clash of Muslims and the State: Waqf and Zakat in Post Independence Indonesia: Studia Islamika 13 (3), hlm. 156-57 
demokrasi, kekuatan partai-partai dan perlemen saat ini kuat, sebaliknya kekuasaan Presiden sebagai kepala eksekutif terbatas dan kehidupan pers yang bebas. ${ }^{214}$

\section{Perjuangan Islam politik Melalui Amandemen Keempat UUD 1945}

Reformasi telah membuka jalan bagi demokrasi dan Islamisasi ruang publik sekaligus gelombang demokrasi pasca-tumbangnya razim Soeharto memungkinkan semua kalangan, termasuk kelompok Islam fundamentalis, berani menyuarakan aspirasi mereka secara lebih terbuka dan vulgar. Dari semua aspirasi yang paling kuat adalah tampilnya Syari'at ke ruang publik. ${ }^{215}$ Munculnya berbagai kelompok Islam seperti Fron Pembela Islam (FPI), Laskar Jihad (LJ), Majelis Mujahidin Indonesia dan lainnya yang menuntut dicantumkannya kembali "dengan kewajiban menjalankan Syari'at Islam bagi pemeluknya" dalam amandemen Pasal 29 UUD 1945 pada tahun 2002. Tuntutan ini didukung oleh beberapa partai meskipun perjuangan melalui parlemen ini gagal, karena tidak didukung oleh mayoritas kekuatan politik di parlemen. Dalam perjuangan ini tidak terjadi gejolak politik yang berarti yang mana menunjukan bahwa tuntutan pemberlakuan Syari'at Syari' at Islam di tingkat pusat oleh berbagai kelompok Islam tersebut tidak mewakili aspirasi kebanyakan umat Islam di Indonesia. ${ }^{216}$

\section{Formalisasi Syari'at Islam di Era Reformasi}

Pada era Reformasi, meskipun gagasan tentang negara berdasarkan agama(Islam) ditolak dalam proses amandemen UUD 1945, ternyata secara masif dilakukan

214 Jimly Asshidiqie, Konstitusi dan Konstitusionalisme Indonesia, (Jakarta: Sinar Grafika, 2011), hlm. 42-43

215 Sukron Kamil dkk., Syariah Islam dan HAM: Dampak Perda Syariah terhadap Kebebasan Sipil, Hak-Hak Perempuan, dan Non-Muslim, (Jakarta: CRSC UIN Syarif Hidayatullah dan KAS, 2007), hlm. xxi

216 Sukron Kamil Dkk., Syariah...Op.Cit., hlm. 108-109 
oleh pemerintah pusat hingga pemerintah daerah. Kenyataan ini menunjukan fenomena akomodasi kepentingan Islam di akhir-akhir kekuasaan Orde Baru. Adapun formalisasi yang terjadi di Era ini sebagai berikut:

a. Undang-Undang Pengelolaan Zakat

Secara historis, sejak Islam masuk ke Indonesia, zakat merupakan salah satu sumber dana untuk pengembangan ajaran Islam. Di zamana kolonial, zakat digunakan untuk perjuangan bangsa Indonesia menentang penjajahan Belanda. Kerena khawatir dana zakat tersebut digunakan untuk melakukan perlawanan, pemerintah Hindia Belanda mengeluarkan Bijblad Nomor 1893 yang berisi kebijakan pemerintah untuk mengawasi pelaksanaan zakat yang dilakukan oleh penghulu atau naib agar tidak terjadi penyelewengan keuangan. Untuk melemahkan kekuatan rakyat yang bersumber dari zakat, pemerintah juga melarang semua pegawai atau priyai pribumi ikut membantu pelaksanaan zakat. Larangan ini ditunjukan dalam Bijblad Nomor 6200 tanggal 28 Februari 1905. Larangan tersebut berdampak negatif pada pelaksanaan zakat bagi umat Islam, sehingga perlawanan umat Islam terhadap penjajah mengalami penurunan. ${ }^{217}$ Sikap pemerintah kolonial bisa dipahami dari teori pemisahan anatara Islam ibadah dan Islam politik dari Snouck Hurgronje. Menurutnya "Musuh Kolonialisme bukanlah Islam sebagai agama, melainkan Islam sebagai doktrin politik." 218 Untuk itu, pemerintah kolonial sangat berhati-hati apabila ibadah zakat 'disalahgunakan' untuk menggalang perlawanan terhadap pemerintah.

Pada tahun 1999, pemerintahan Presiden B.J. Habibie mengesahkan Undang-Undang Nomor 38 tahun 1999 tentang Pengelolaan Zakat. Penjelasan atas

217 Muharam Marzuki dkk., Islam untuk Disiplin Ilmu Hukum, (Dirjen Kelembagaan Agama Islam Departemen Agama RI, 2002), hlm. 150-151

218 Aqib Suminto, Politik Islam Hindia-Belanda, (Jakarta: LP3ES, 1986), hlm. 11. 
Undang-Undang Nomor 38 tahun 1999 menyatakan bahwa Bangsa Indonesia senantiasa melaksanakan pembangunan yang bersifat fisik materiil mental spiritual, antara lain melalui pembangunan di bidang agama. Zakat merupakan sumber dana potensial yang dapat dimanfaatkan untuk memajukan kesejahteraan umum bagi seluruh masyarakat. denagn dibentuknya Undang-undang tentang Pengelolaan Zakat. Dalam Pasal 2 Undang-undang ini menyatakan pengakuan negara tentang kewajiban Muslim, "setiap warga negara Indonesia yang beragama Islam dan mampu atau badan yang dimiliki oleh muslim berkewajiban menunaikan zakat."

Selanjutnya, karena Undang-undang Nomor 38 tahun 1999 tentang Pengelolaan Zakat dianggap sudah tidak sesuai dengan perkembangan kebutuhan hukum dalam masyarakat, maka pemerintah menggantinya dengan Undang-undang No 23 Tahun 2011 tentang Pengelolaan Zakat. Dalam upaya mencapai tujuan pengelolaan zakat, dibentuk Badan Amil Zakat Nasional (BAZNAS) yang berkedudukan di ibukota negara. BAZNAS provinsi, dan BAZNAS kabupaten/kota. BAZNAS merupakan lembaga pemerintah nonstruktural tang bersifat mandiri dan bertanggung jawab kepada Presiden melalui Menteri. BAZNAS merupakan lembaga yang berwenang melakukan tugas pengelolaan zakat secara nasional. Untuk membantu BAZNAS dibentulah Lembaga Amil Zakat (LAZ) yang memiliki tugas pelaksanaan pengumpulan, pendistribusian, dan pendayagunaan zakat secara nasional. ${ }^{219}$ Pengelolaan zakat mendapat fasilitas dari pemerintah melalui pembentukan lembaga pengelola zakat dan pengatur formal dengan payung Undang-Undang Pengelolaan

219 Penjelasan Atas Undang-undang No 23 tahun 2011 Tentang Pengelolaan Zakat. 
Zakat. Zakat dianggap sebagai ibadah murni sebagai salah satu aspek pembangunan nasional.

b. Undang-Undang Wakaf

Pengaturan wakaf erat kaitanya denagn sosial dan adat di Indonesia, maka dalam pelaksanaanya disesuaikan dengan hukum adat yang berlaku di Indonesia, denagn tidak mengurangi nilai-nilai ajaran Islam yang terdapat dalam wakaf itu sendiri. ${ }^{220} \mathrm{Di}$ zaman Hindia-Belanda tahun 1905 pemerintah memberikan edaran berupa Bijblad bahwa wakaf tanah harus memberi tahu kepada pemerintah agar tidak terkena perubahan dan rencana yang dibuat pemerintah. Adanya pemberitahuan itu, pemerintah dapat menunjuk tanah yang diwakafkan agar tidak terkena gusuran atau kepentingan pemerintah, sehingga wakaf dapat berfungsi seterusnya. Pada tahun 1931, 1934, dan 1936 pemerintah membuat aturan berupa Bijblad-Bijblad dan tidak mengubah hukum Islam tentang wakaf. ${ }^{221}$ Setelah Proklamasi 17 Agustus 1945, peraturan wakaf tetap berlaku berdasarkan bunyi Pasal II Aturan Peralihan UUD 1945. Dan sejak 1946 urusan tanah wakaf menjadi urusan Kemanterian Agama bagian D (ibadah sosial). Hal ini didasarkan pula pada Peratiran Pemerintah Nomor 33 Tahun 1949 dan Peraturan Menteri Agama Nomor 9 dan 10 tahun 1952. Peraturan ini menyatakan bahwa Jawatan Urusan Agama, denagn kantor-kantor seluran vertikal di daerah: KUAP, KUAK, dan KUA Kecamatan mempunyai kewajiban menyelidiki, menentukan, mendaftar, dan mengawasiatau menyelenggarakan pemilihan wakaf. Dengan demikian wakaf tanah menajdi wewenang Menteri Agama dan

220 Achmad Djunaidi dan Thobieb Al-Asyhar, Menuju Era Wakaf Produktif: Sebuah Upaya Progresif untuk Kesejahteraan Umat, (Jakarta: Mitra Abadi Press, 2006), hlm. 47.

221 Rachmadi Usman, Hukum Perwakafan di Indonesia, (Jakarta: Penerbit Sinar Grafika, 2013) hlm. 9-10. 
dalam pelaksanaan dilimpahkan kepada Kepala Akntor Urusan Agama Kebupaten.222 Lahirnya Undang-Undang Nomor 5 Tahun 1960 tentang Peraturan Dasar Pokok-pokok Agraria telah memperkokoh eksistensi wakaf di Indoensia dan menjadi perhatian pemerintah. ${ }^{223}$ Oleh karena itu dalam Pasal 49 Undang-Undang Nomor 5 Tahun 1960 menyatakan:

1) Hak milik tanah badan-badan keagamaan dan sosial sepanjang dipergunakan untuk usaha dalam bidang keagamaan dan sosial, diakui dan dilindungi. Badan-badan tersebut dijamin pula akan memperoleh tanah yang cukup untuk bangunan dan usahanya dalam bidang keagamaan dan sosial;

2) Untuk keperluan peribadatan dan keprluan suci lainya sebagai dimaksud dalam Pasal 14 dapat diberikan tanah yang dikuasai langsung oleh negara denagn hak pakai;

3) Perwakafan tanah milik dilindungi dan diatur dengan Peraturan Pemerintah.

Sejak berlakunya peraturan ini maka semua peraturan perundang-undangan tentang perwakafan sebelumnya dinyatakan tidak berlaku. Untuk memperkuat eksistensi perwakafan di Indonesia, Undang-Undang Nomor 7 Tahun 1989 tentang Peradilan Agama dikeluarkan sebagaimana yang tertuang dalam pasal 49. Sebagai hukum materiil untuk menjadi pegangan hakim Peradilan Agama dalam memutuskan sengketa wakaf, pemerintah mengeluarkan Kompilasi Hukum Islam (KHI) Buku III tentang Hukum Perwakafan. Tahun 2004 Presiden Soesilo Bambang Yudhoyono mengesahkan Undang-undang Nomor 41 Tahun 2004 tentang Wakaf, berbagai hal penting tentang pengembangan wakaf dapat dioptimalkan, terutama tentang masalah nazir, harta benda yang diwakafkan,

222 Sahid HM., Legislasi..., Op.Cit., hlm. 108.

223 Ibid., hlm. 108-109. 
peruntukan harta wakaf dan tentang wakaf tunai maupun produktif. 224 Denagn demikian dalam Undang-undang ini telah terjadi modernisasi pengertian badan wakaf untuk menyesuaikan zaman modern.

c. Formalisasi Ekonomi Syariah

Untuk mengakomodasi sistem ekonomi Syariah, pemerintah mengizinkan beroprasinya bank Syariah melalui serangkaian peraturan perundang-undangan. Ada beberapa peratura yang mendukung perkembangan hukum ekonomi Syariah di Indonesia, diantaranya:

1) Undang-Undang Nomor 7 Tahun 1992 tentang Perbankan;

2) Peraturan Pemerintah Nomor 72 Tahun 1922 tentang Bank Berdasarkan Bagi Hasil;

3) Peraturan Pemerintah Nomor 73 Tahun 1992 tentang Bank Perkreditan Rakyat Berdasarkan Bagi Hasil;

4) Undang-Undang Nomor 10 Tahun 1998 tentang Perubahan atas Undang-Undang Nomor 7 Tahun 1992 tentang Perbankan;

5) Undang-Undang Nomor 21 Tahun 2008 tentang Perbankan;

6) Undang-Undang Nomor 19 Tahun 2008 tentang Surat Berharga Syariah Negara;

7) Peraturan Mahkamah Agung (PERMA) Nomor 2 Tahun 2008 tentang Kompilasi Hukum Ekonomi Syariah. ${ }^{225}$

Pendirian Bank Muamalat Indonesia (BMI) dan Bank Perkreditan Rakyat (BPR) Islam memberikan angin segar bagi umat Islam. Pada awal pendirian BMI keberadaan bank Syari'ah belum mendapat perhatian yang optimal dalam tatanan industri perbankan nasional.

224 Abdul Manan, Aneka Masalah Hukum Perdata Islam di Indonesia, (Jakarta: Kencana, 2006), hlm. 253-254

225 Mardani, Hukum Bisnis Syariah, (Jakarta: Prenada media Group, 2014), hlm. 70. 
Bank yang menggunakan sistem Syari'ah hanya disebut sebagai "bank dengan sistem bagi hasil,". Peluang beroprasinya perbankan berdasarkan prinsip Syari'ah semakin jelas dengan lahirnya Undang-undang Nomor 10 Tahun 1998 tentang Perubahan atas Undang-Undang Nomor 7 Tahun 1992, kejelasan peluang tersebut dapat dilihat pada Pasal 1 angka 12, Pasal 6 huruf (u), Pasal 7 huruf (c), Pasal 8 ayat (1) dan beberapa pasal lainya. Dalam Undang-undang tersebut diatur denagn rinci landasan hukum serta jenis-jenis usaha yang dapat dioprasikan dan diimplementasikan oleh bank Syariah. Undang-Undang ini yang mengawali tumbuh dan berkembang pesatnya perbankan Syariah di Indonesia. 226

\section{Politik Hukum Zakat, Wakaf, dan Ekonomi Syari'ah}

Undang-undang tentang administrasi zakat pasca Orde Baru sebagai implikasi birokrasi. Ada dua Undang-undang penting tentang zakat yaitu Undang-Undang Nomor 38 tahun 1999 tentang Zakat dan Undang-Undang Nomor 23 tahun 2011 tentang Zakat. Kedua Undang-undang ini diumumkan secara resmi sebagai tanggapan atas tuntutan penerapan administrasi zakat di bawah lembaga hukum yang dapat langsung mengarah ke perbaikan sosial dan ekonomi. Tujuan mendasar dari administrasi zakat adalah untuk mengamankan keadilan dan mewujudkan kesejahteraan sosial di kalangan umat Islam. Adanya administrasi ini berkaitan denagn mekanisme tata pemerintahan yang baik di Indonesia yang erat kaitanya denagn transparasi, distribusi keadilan, pengawasan dan dampak untuk tujuan agama, ekonomi, dan sosial. Adanya aturan ini memungkinkan keterlibatan publik dalam mempercepat penggalangan dana zakat baik pengumpulan secara kolektif melalui kolaborasi dengan lembaga swasta maupun publik. Intansi zakat diizinkan bekerja sama dengan bank dan perusahaan swasta dalam mengumpulkan dana baik lembaga pemerintah maupun lembaga non pemerintah

226 Sahid HM., Legislasi..., Op.Cit., hlm. 126-127. 
sebagaimana yang tertera dalam kedua Undang-undang tersebut. Undang-undang ini juga mencakup bentuk sedekah seperti hibah, sadaqah, dan macam-macam zakat. Hal ini merupakan indikasi interpretasi modern yang tidak hanya sebagai sebuah ritual keagamaan saja melainkan dasar sosial berupa engatasi kemiskinan dan penerapan keadialn dalam masyarakat.

Dalam dua Undang-undang ini dua jenis lembaga zakat berwenang secara hukum mengatur zakat yaitu BAZNAS dan LAZ seperti yang sudah di jelasakan di atas. Dalam versi terbaru dari Undang-Undang zakat Nomor 23 tahun 2011, posisi BAZNAS lebih signifikan terutama mengenai peranan dalam pengawasan zakat. BAZNAS memiliki wewenang untuk mengawasi LAZ dan merekomendasikan pendirian LAZ. Di masa lalu otoritas ini diberikan kepada direktorat zakat dan wakaf di Kementrian Agama. Posisi BAZNAS di tingkat nasional, provinsi, dan kabupaten/kota menjadi sangat penting sebagai kekuatan politik, sosial, dan ekonomi. Administrasi ini bukan sebagai bentuk Syari'at tetapi lebih merupakan upaya untuk mnegatur zakat di kalangan umat Islam melalui sistem menajemen modern. Pendekatan ini dapat mengasilkan dua konsekuensi yaitu distribusi zakat akan digunakan untuk tindakan prioritas dalam mendukung kebutuhan masyarakat tidak mampu dan pengumpulan zakat di kalangan umat Islam dapat diperkirakan setiap tahun manfaat pengembangan program dalam pengentasan kemiskinan. Sementara di tingkat nasional kedudukan hukum administrasi zakat bertujuan untuk mengamankan administrasi birokrasi. 227

Pengumpulan wajib zakat bagi pegawai pemerintah yang langsng dipotong dari gaji bulanan merupakan bentuk dari mengambil kendali atas adminitrasi zakat dibawah otoritas sebagai sarana untuk memajukan kepentingan politik. Bahwa apa yang menjadi pewajiban sudah sesuai denagn tuntutan agama. Secara tidak langsng aturan ini akan berimplikasi pada pandangan masyarakat tentang pemimpin yang agamis yang

227 Asep Saepudin Jahar, BUREAUCRATIZING...Op.Cit. hlm. 217-219 
peduli terhadap muslim dan masyarakat tidak mampu, secara politis strategi ini umumnya akan mendapat dukungan langsung dari masyarakat.

Implementasi Islam di Indoensia khususnya dalam zakat, wakaf dan ekonomi Syariah bukanlah upaya Syariahisasi atau islamisasi melainkan upaya memeperkuat neagra modern dan demokratis yang mengharuskan birokratisasi agama. Institusionalisasi Syariah dalam institusi negara dan aturan resmi adalah bentuk birokratisasi rasional. Hal ini dilakukan untuk mereorganisasi kehidupan sosial, termasuk tradisi keagamaan di bawah sistem negara. Konsekuensi menanamkan Islam ke dalam sistem negara adalah dengan dibentuknya administrasi aturan tertulis yang formal dan rasional. Posisi Depag (Departemen Agama) dan Pengadilan Agama sebagai institusi negara adalah aspek penting untuk dipertimbangkan terkait biroktarisasi wakaf, zakat dan aturan berbasias agama Islam lainnya. Tren modernisasi melibatkan adopsi mekanisme birokrasi sebagai kendaraan untuk mengelola organisasi di dalam maupun di luar. Islam di Indonesia dituntut untuk beradaptasi dan bernegosiasi dengan sistem negara modern yang ada harus sesuai dengan aturan sekuler daripada mengganti hukum yang ada. Birokratisasi dapat mengambil berbagai pendekatan sesuai dengan kebutuhan sosial tertentu dan realitas. Penegakan Syari'ah yang memiliki konotasi keagamaan yang kental membutuhkan kurang lebih legitimasi, prosedur dan proses formal. Hal ini sejalan dengan kecenderungan transformasi dari birokrasi keagamaan dan lembaga keagamaan yang mirip dengan adaptasi sekuler Islam daripada proses de-sekularisasi.

\section{Penutup}

Di Indonesia, birokrasi Syari'ah telah muncul sebagai bentuk menanggapi kebutuhan untuk mengatur kehidupan Muslim dalam rangka negara modern. Adanya administrasi hukum zakat, wakaf dan keperdataan lain yang menyangkut agama menunjukan bagaimana pemerintah berupaya 
menerapkan Syari'ah dalam kerangka negara konstitusional yang berkomitmen untuk demokratis terhadap hukum yang plural dan Pancasila. Meskipun Syari'ah telah mengakali birokrasi, isi hukum Syari'ah telah dikembangkan, diadaptasi dan dipilih dari prinsip-prinsip fiqh klasik suni yang sangat umum dalam lingkungan Islam Indonesia.

Hal ini mencerminkan adanya tren pemerintahan negara modern yang membutuhkan rasionalisasi dan kepastian dalam mengatur masyarakat. positifisasi Undang-undang ini bertujuan untuk memberikan kepastian hukum dan keadilan bagi semua muslim di bawah payung hukum. Birokrasi ini memiliki dua konsequensi yaitu doktrin Islam telah di modernisasi dan masalah hukum yang terkait denagn sosial keagamaan telah dilembagakan dan peraturan hukum telah diformalkan untuk memastikan hak-hak orang dilindungi dalam kerangka hukum negara dan Pancasila. 


\section{Daftar Pustaka}

\section{Buku}

Asshidiqie, Jimly. 2011. Konstitusi dan Konstitusionalisme Indonesia, (Jakarta: Sinar Grafika)

D.S. Lev. 1980. Peradilan Agama Islam di Indonesia: Suatu Studi tentang Landasan Politik Lembaga-lembaga Hukum, alih bahasa Zaini Ahmad Noeh, (Jakarta: Intermasa)

Djunaidi, Achmad dan Thobieb Al-Asyhar. 2006. Menuju Era Wakaf Produktif: Sebuah Upaya Progresif untuk Kesejahteraan Umat (Jakarta: Mitra Abadi Press)

Effendy, Bahtiar. 2011. Islam dan Negara: Transformasi Gagasan dan Praktik Politik Islam di Indonesia, (Jakarta: Democracy Project-Yayasan Abad Demokrasi)

Fadlullah, Cholid. Mengenal Hukum Hukum ZIS (Zakat, Infaq/Sedekah) dan Pengalamannya di DKI Jakarta, (Jakarta: BAZIS DKI Jakarta)

Gunaryo, Achmad. 2006. Pergumulan Politik dan Hukum Islam: Reposisi Peradilan Agama dari peradilan "Pupuk Bawang" Menuju Peradilan yang Sesungguhnya. (Yogyakarta: Pustaka Pelajar)

HM., Sahid. 2016. Legislasi Hukum Islam di Indonesia: Studi Formalisasi Syari'at Islam, (Surabaya: Pustaka Idea)

Jahar, Asep Saepudin. 2006. The Clash of Muslims and the State: Waqf and Zakat in Post Independence Indonesia. (Jakarta: Studia Islamika 13 (3)Journal For Islamic Studies)

2019. Bureaucratizing Sharia In Modern Indonesia: The Case Of Zakat, Waqaf And Family Law, (Jakarta: Studia Islamika: Indonesia Jornal For Islam Studies) 
Kamil, Sukron, dkk.. 2007. Syariah Islam dan HAM: Dampak Perda Syariah terhadap Kebebasan Sipil, Hak-Hak Perempuan, dan Non-Muslim, (Jakarta: CRSC UIN Syarif Hidayatullah dan KAS)

Manan, Abdul. 2006. Aneka Masalah Hukum Perdata Islam di Indonesia (Jakarta: Kencana)

Mardani. 2014. Hukum Bisnis Syariah, (Jakarta: Prenada media Group)

Marzuki, Muharam, dkk.. 2002. Islam untuk Disiplin Ilmu Hukum, (Dirjen Kelembagaan Agama Islam Departemen Agama RI)

MD, Moh. Mahfud. 2012. Politik Hukum di Indonesia, (Jakarta: RajaGrafindo Persada)

Noer, Deliar. 1983. Administrasi Islam di Indonesia, (Jakarta: Rajawali)

Penjelasan Atas Undang-undang No 23 tahun 2011 Tentang Pengelolaan Zakat.

Rahardjo, M Dawam. 1986. "Zakat dalam Prespektif Sosial Ekonomi," dalam Pesantren nomor 2/vol. III/1986

Suminto, Aqib. 1986. Politik Islam Hindia-Belanda (Jakarta: LP3ES)

Taba, Abdul Aziz. 1996. Islam dan Negara dalam Politik Orde Baru, (Jakarta: Gema Insani Press)

Undang-undang No. 4 Tahun 1950 Tentang Dasar-dasar Pendidikan dan Pengadjaran di sekolah.

Usman, Rachmadi. 2013. Hukum Perwakafan di Indonesia (Jakarta: Penerbit Sinar Grafika) 
Zaman, Muhammad Qasim. The Ulama in Contemporary Islam: Custodians of Change, (Princeton: Princeton Univ. Press) 
POLITIK HUKUM PENGATURAN HAK ATAS TANAH

DALAM PENANAMAN MODAL DAN IMPLIKASINYA TERHADAP KESEJAHTERAAN RAKYAT

\section{Reni Ratna Anggreini \\ Mahasiswa Program Magister Ilmu Hukum Universitas Islam Indonesia \\ Email: renyratna2795@gmail.com}

\section{A. Pendahuluan}

Investasi merupakan salah satu penggerak proses penguatan perekonomian negara, karena itu untuk mempercepat pembangunan ekonomi dan mewujudkan kedaulatan politik dan ekonomi Indonesia diperlukan peningkatan penanaman modal untuk mengolah potensi ekonomi riil dengan menggunakan modal yang berasal, baik dari dalam negeri maupun dari luar negeri. Pengaturan penanaman modal atau investasi pada dasarnya meliputi hak atas tanah yang merupakan salah satu masalah pokok dalam kegiatan investasi di Indonesia. Mengingat tanah memiliki arti yang sangat penting dalam investasi, maka kebijakan ekonomi pemerintah diorientasikan untuk kemudahan investasi.

Perubahan itu ditandai dengan ditetapkannya Undang-Undang Nomor 25 Tahun 2007 tentang Penanaman Modal. Pertimbangan pemerintah ini juga dilandasi ketika Indonesia menghadapi perubahan ekonomi global dan keikutsertaan Indonesia dalam berbagai kerja sama internasional perlu diciptakan iklim penanaman modal yang kondusif, promotif, memberikan kepastian hukum, keadilan, dan efisien dengan tetap memperhatikan kepentingan ekonomi nasional.Kebijakan investasi atau penanaman modal di Indonesia pada dasarnya merujuk pada ketentuan Pasal 33 UUD 1945. Esensialisasi Pasal 33 UUD 1945 adalah 
perekonomian Indonesia berorientasi pada ekonomi kerakyatan. 228

Kemudian, terkait pengaturan mengenai hak atas tanah dalam UU No. 25 Tahun 2007 tentang Penanaman modal, terdapat ketentuannya dalam Pasal 21 dan Pasal 22.229 Dalam pasal tersebut diatur mengenai kemudahan akses dalam memperoleh hak atas tanah untuk kepentingan penanaman modal yang terdiri atas Hak Guna Usaha (HGU), Hak Guna Bangunan (HGB), dan Hak Pakai. Tujuannya adalah sebagai promosi dengan harapan bahwa para investor atau pemodal akan tertarik dan menanamkan modalnya serta menjalankan usahanya di Indonesia.

Landasan utama pengaturan penguasaan atas tanah untuk usaha-usaha dibidang agraria diatur dalam Undang-Undang Nomor 5 Tahun 1960 tentang Peraturan Dasar Pokok-Pokok Agraria (UUPA). Kemudian diatur lanjut dalam peraturan pelaksananya yaitu dalam Peraturan Pemerintah Nomor 40 Tahun 1996 tentang Hak Guna Usaha, Hak Guna Bangunan, dan Hak Pakai. Namun, pada Peraturan Pemerintah No. 40 Tahun 1996, pemerintah dinilai lebih memberikan kelonggaran kepada para investor atau pemodal untuk jangka waktu penguasaan tanah yang relative lebih lama

228 Ekonomi kerakyatan adalah suatu sistem ekonomi yang menjamin keterlibatan rakyat sebagai subjek yang mengendalikan jalannya roda ekonomi negara, atau suatu sistem perekonomian yang menjamin dilakukannya produksi oleh semua, untuk semua, dibawah pimpinan atau kepemilikan rakyat. Sritua Arif, Ekonomi Kerakyatan Indonesia: Mengenang Bung Hatta Bapak Ekonomi Kerakyatan Indonesia, (Surakarta: Muhammadiyah University Press, 2002) hlm.153

229 Pasal 21 UUPM menyatakan Pemerintah memberikan kemudahan pelayanan dan/atau perizinan kepada perusahaan penanaman modal salah satunya untuk memperoleh hak atas tanah. Pasal 22 ayat (1) yang menyatakan: Kemudahan pelayanan dan/atau perizinan hak atas tanah sebagaimana dimaksud dapat diberikan dan diperpanjang di muka sekaligus dan dapat diperbarui kembali atas permohonan penanam modal, berupa : (a) HGU dapat diberikan dengan jumlah 95 tahun dengan cara dapat diberikan dan diperpanjang di muka sekaligus selama 60 tahun dan dapat diperbarui selama 35 tahun; (b) HGB dapat diberikan dengan jumlah 80 tahun dengan cara dapat diperpanjang di muka sekaligus selama 50 tahun dan dapat diperbarui selama 30 tahun; dan (c) Hak Pakai dapat diberikan dengan jumlah 70 tahun dengan cara diperpanjang di muka sekaligus selama 45 tahun dan dapat diperbarui selama 25 tahun. 
dibandingkan dengan undang-undang sektoralnya yaitu UU Pokok Agraria. Selain itu, ketentuan jangka waktu penguasaan atas tanah ini juga terdapat perbedaan antara Undang-Undang No. 25 Tahun 2007 (UUPM) dengan Undang-Undang No. 5 Tahun 1960 (UUPA).

Dalam rangka pemberian hak atas tanah tersebut seringkali negara dengan hak menguasai negara memberikan tanah yang dikuasai langsung oleh negara maupun tanah-tanah yang dikuasai oleh masyarakat hukum adat (tanah-tanah adat). Namun demikian seringkali pemberian hak atas tanah itu kurang memberikan perlindungan terhadap tanah yang dikuasai oleh rakyat. Terhadap hak atas tanah yang sering menuai konflik adalah pengaturan Hak Guna Usaha dalam PP No. 40 Tahun 1996. Menurut Pasal 8 ayat (1) menyebutkan bahwa "HGU dapat dapat diberikan untuk jangka waktu paling lama 35 tahun dan dapat diperpanjang paling lama 25 tahun". Pernyataan dalam Pasal 1 masih sejalan dengan UUPA, namun ada pernyataan tambahan pada Pasal 8 ayat (2), yaitu "sesudah jangka waktu Hak Guna Usaha dan perpanjangannya sebagaimana dimaksud dalam ayat (1) berakhir, kepada pemengang hak dapat diberikan pembaharuan Hak Guna Usaha di atas tanah yang sama". Pernyataan tersebut dianggap telah melenceng dengan ketentuan dalam UUPA yang mana tanpa adanya pembaharuan lagi terhadap pemberian hak atas tanah termasuk HGU.

Hal ini juga sama dengan ketentuannya dalam Pasal 22 UU Penanaman Modal yang mana "dapat diperpanjang dimuka sekaligus dan dapat diperbarui kembali". Hal ini secara langsung akan memberikan kerancuan terhadap penerapan hukum dalam pemberian hak atas tanah dilapangan. Pada dasarnya bagi masyarakat agraria yang mengutamakan kesejahteraan rakyat dalam penerapan pemberian hak atas tanah akan tetap berpegang teguh pada Undang-Undang No. 5 Tahun 1960 (UUPA). Sedangkan bagi pihak investor atau pemodal, mereka akan cenderung mengutamakan keuntungan individu dan berharap banyak 
terhadap kemudahan yang diberikan pemerintah melalui Undang-Undang No. 25 Tahun 2007 (UUPM). Apabila melihat struktur hukum yang mendukung pelaksanaan kebijakan tersebut dengan kompetensi dan jumlah sumber daya yang terbatas akan menjadikan pelaksanaan dilapangan menjadi tumpang tindih dan tidak adanya kepastian hukum. ${ }^{230}$

Beberapa contoh konflik tanah antara masyarakat dengan pengusaha atau investor setelah diberlakukannya Peraturan Pemerintah No. 40 Tahun 1996, adalah kasus Perkebunan Kakao PT. Delta Subur Permai, Kabupaten Luwuk, Sulawesi Tengah tentang pengambilan tanah masyarakat Seseba atas nama izin HGU di dataran Banggai oleh perusahaan untuk perkebunan kakao. Konflik muncul karena lahan perkebunan kakao milik masyarakat diambil paksa oleh perusahaan. ${ }^{231}$ Kemudian kasus yang serupa terjadi di Kecamatan Sukolilo, Pati, Jawa Tengah yaitu antara PT. Semen Gresik dengan warga Samin yang bermata pencaharian sebagai petani, konflik muncul karena lahan pertanian milik mereka akan diambil alih oleh perusahaan semen atas nama HGU yang melibatkan aparat pemerintah dan militer. ${ }^{232}$

Melihat permasalahan di atas besar kemungkinan akan terjadi penindasan terhadap kaum petani yang selama ini sudah terpinggirkan dan akan semakin terpuruk karena ketiadaan lahan dan tidak mempunyai keahlian yang khusus apabila akan terlibat sebagai tenaga kerja dalam bidang usaha agraria yang dilaksanakan oleh investor atau pemodal. Kebijakan pemerintah dalam UU No. 25 Tahun 2007 (UUPM) dan PP No.40 Tahun 1996 dinilai tidak berpihak kepada kepentingan rakyat dan telah mencederai Pasal 33 UUD 1945.

230 Ketidakpastian hukum disebabkan oleh beberapa faktor, salah satunya adalah substansi peraturan perundang-undangan yang tidak sinkron. Siti Anisah dan Lucky Suryo Wicaksono, Hukum Investasi, (Yogyakarta: FH UII Press, 2017), hlm. 58

${ }^{231}$ https:/ / www.mongabay.co.id/2013/11/12/sawit-di-banggai-dari-penye robotan-lahan-sampai-ekspansi-di-cagar-alam/ Diakses pada 10 Juni 2020

232 https://news.detik.com/berita/d-924481/warga-samin-tolak-pembangu nan-pabrik-semen-gresik Diakses pada 10 Juni 2020 
Berkaitan dengan Pasal 33 UUD 1945, Boedi Harsono berpendapat bahwa "bangsa Indonesia memberikan amanat yang besar kepada Negara dengan memberikan hak menguasai." 233 Hak menguasai dari Negara yang bersumber pada hak bangsa melalui pernyataan dalam Pasal 33 ayat (3) UUD 1945 yang berbunyi "Bumi dan air dan kekayaan alam yang terkandung di dalamnya dikuasai oleh negara dan dipergunakan untuk sebesar-besarnya kemakmuran rakyat". Pengertian meguasai terletak pada hukum publik dan Negara bertindak sebagai penguasa, namun penguasaan tersebut harus menuju pada kesejahteraan dan kemakmuran rakyat. ${ }^{234}$

Tanah dalam wilayah Negara Republik Indonesia merupakan salah satu sumber daya utama, yang selain mempunyai nilai batiniah yang mendalam bagi rakyat Indonesia, juga berfungsi sangat strategis dalam memenuhi kebutuhan rakyat yang makin beragam dan meningkat, baik dalam tingkat nasional maupun dalam hubunganya dengan dunia Internasional. Sebagaimana diketahui masalah tanah merupakan masalah yang multidimensial, berkaitan dengan aspek politik, ekonomi, sosial, budaya maupun ekologi. Sifat konstan dari tanah dan terus bertambahnya manusia yang membutuhkan tanah, hal ini secara langsung juga akan menambah tinggi nilai tanah. Secara filosofis tanah adalah untuk kesejahteraan rakyat, sedangkan tujuan pengaturan hukum adalah keadilan.

Melihat beberapa contoh kasus pertanahan yang ada di Indonesia dan dikaitkan dengan kebijakan pemerintah dalam rangka peningkatan investasi, maka kajian politik hukum pertanahan dalam pengaturan penanaman modal di Indonesia juga merupakan salah satu bentuk konfigurasi politik tertentu yang akan melahirkan produk hukum dengan karakter tertentu. Politik dan hukum berangkat dari asumsi bahwa hukum merupakan produk politik sehingga hukum dipandang

233 Boedi Harsono, Menuju Kesempurnaan Hukum Tanah Nasional, (Jakarta: Universitas Trisakti, 2007), hlm.47

234 Ibid., hlm.49 
sebagai formalisasi yuridis dari kehendak-kehendak politik yang saling berinteraksi dan berkaitan. ${ }^{235}$ Politik hukum memegang peran yang penting bagi berfungsi atau tidaknya suatu pranata hukum sebagai filter terhadap munculnya berbagai kepentingan dimaksud. Sebagai negara yang sedang berkembang, Indonesia memerlukan keberadaan investor dalam mengembangkan pembangunan wilayahnya. Atas dasar pemikiran di atas, tampak secara mendasar bahwa di dalam kegiatan investasi diperlukan turut sertanya pemerintah berperan serta dalam mengantisipasi iklim investasi dalam suatu negara.

Berkaca dari kegagalan era sebelumnya yaitu era orde lama dan orde baru, pemerintah mencoba menetralisir antara lain dengan menata ulang rumusan kebijakan penatagunaan tanah yang berkaitan dengan kepentingan umum. Terakhir dengan keluarnya Perpres 36 Tahun 2005 yang kemudian diamandemen dengan Perpres 65 Tahun 2006 tentang Pengadaan Tanah Bagi Pelaksanaan Pembangunan Untuk Kepentingan Umum. Namun, aturan tersebut terkesan berpihak kepada pemilik tanah dengan memberikan definisi lebih konkret mengenai makna kepentingan umum. Namun terhadap implementasinya di lapangan ternyata aturan ini masih menuai kritik dari berbagai pihak karena masih ada kesan dominasi pemerintah terhadap penentuan politik kebijakan penatagunaan tanah dalam konteks investasi. Publik masih menengarai bahwa rumusan kepentingan umum merupakan sebagian alih-alih pemerintah untuk mempercepat proses peralihan hak atas tanah kepada investor melalui konsinyasi ganti rugi ke pengadilan meskipun berstatus titipan. 236

235 Mengenai hubungan antara hukum dan politik secara teoritis sebenarnya bisa dipergunakan asumsi yang berbalikan yaitu hukum yang mempengaruhi poitik atau politik yang mempengaruhi hukum. Moh. Mahfud MD, Politik Hukum di Indonesia, (Jakarta: Penerbit PT. Raja Grafindo Persada, 2012), hal. 293

${ }^{236}$ I Gede A.B Wiranto, “Urgensi dan Relevansi Pengaturan Tanah dalam Kegiatan Penanaman Modal Atau Investasi", Jurnal Hukum dan Dinamika Masyarakat, Edisi No.2 Vol.4, (2007), hlm 134-135 
Memperhatikan vitalnya fungsi tanah dalam kegiatan investasi, dikaitkan dengan keberadaan tanah yang telah diamanatkan dalam sistem hukum nasional yaitu bahwa tanah memiliki fungsi sosial, maka tulisan ini hendak memberikan sumbangan pemikiran ke arah politik hukum pengelolaan tentang tanah dalam rangka peningkatan investasi dalam undang-undang penanaman modal di Indonesia. Berdasarkan hal tersebut, maka sangat menarik untuk di kaji terkait apakah pembentukan UUPM terdapat sinkronisasi dengan UUPA dalam hal pemberian hak atas tanah untuk kegiatan investasi. Mengingat pengaturan mengenai jangka waktu perpanjangan dalam UUPM yang jauh lebih lama dibanding dengan UUPA dapat menimbulkan ketidakadilan bagi masyarakat Indonesia. Berdasarkan uraian tersebut, menarik untuk menelusuri arah politik hukum pengaturan hak atas tanah dalam kegiatan investasi atau penanaman modal di Indonesia dan implikasi politik hukum pertanahan dalam upaya peningkatan investasi terhadap kesejahteraan ekonomi rakyat?

\section{B. Arah Politik Hukum Pengaturan Hak Atas Tanah Dalam Kegiatan Investasi atau Penanaman Modal di Indonesia}

\section{Pengertian Politik Hukum}

Politik hukum menurut Mahfud MD adalah legal policy atau garis (kebijakan) resmi tentang hukum yang akan diberlakukan baik dengan pembuatan hukum baru maupun dengan penggantian hukum lama, dalam rangka mencapai tujuan negara. 237 Sedangkan Padmo wahyono mengatakan politik hukum adalah kebijakan dasar yang menentukan arah, bentuk, maupun isi hukum yang akan dibentuk. Selain itu juga Padmo Wahjono memperjelas definisi tersebut dengan menyatakan bahwa kebijakan penyelenggaraan negara terkait kriteria dalam pembentukan hukum baik dari segi penerapan dan juga penegakan hukum itu sendiri. ${ }^{238}$ Satjipto Rahardjo mendefinisikan politik hukum sebagai

237 Moh. Mahfud MD, op.cit., hlm.1

238 Moh. Mahfud MD, loc.cit 
suatu proses keharusan untuk menentukan suatu pilihan mengenai tujuan maupun cara-cara yang hendak dijalankan untuk mencapai tujuan. ${ }^{239}$ Politik hukum adalah persoalan pencapaian tujuan bersama. Untuk mencapai tujuan yang diinginkan, maka ruang lingkup politik hukum mencakup 3 (tiga) hal, yaitu: 1) Tujuan (ideal) yang hendak dicapai melalui hukum; 2) Cara atau metode yang tepat untuk mencapai tujuan itu; dan 3) Konfigurasi hukum yang efektif mewujudkan tujuan tersebut. ${ }^{240}$

Kemudian, bagaimana posisi hukum itu sendiri ketika berhadapan dengan hukum politik, ada 3 (tiga) kategori hukum yaitu Pertama, hukum bersifat represif adalah di mana hukum hanya menjadi alat politik yaitu sebagai legalitas kepentingan politik tertentu yang berakses kuat. Kedua, hukum bersifat otonom (mandiri) dan terlepas dari komponen kekuatan lain di mana hukum ditegakkan oleh hukum itu sendiri. Ketiga, hukum bersifat responsif yaitu hukum sebagai bentuk dari hasil reduksi berbagai kepentingan politik dan dijadikan sebagai keputusan hukum yang bernilai keadilan. ${ }^{241}$

Sejatinya hukum dan politik saling mempengaruhi, tidak ada yang lebih unggul. Adanya asumsi bahwa hukum merupakan produk politik (politik determinan atas hukum), politik sebagai independent variable secara ekstrem dibedakan atas politik yang demokratis dan politik yang otoriter. Sedangkan hukum sebagai dependent variable dibedakan atas hukum yang responsif dan hukum yang ortodoks. Politik demokratis adalah sistem politik yang membuka kesempatan bagi partisipasi rakyat secara aktif dalam menentukan kebijaksanaan umum, politik otoriter adalah

239 Satjipto Rahardjo, Ilmu Hukum, Cetakan Ketujuh, (Bandung: Titra Aditya Bhakti, 2012) hlm. 398-399

240 Bernard L. Tanya, Politik Hukum Agenda Kepentingan Bersama, (Yogyakarta: Genta Publishing, 2011), hlm. 6

241 Philipe Nonet Philip Selzink, Law and Society in Transition Toward Responsive Law (New York: Harper and Row, 1978), Dikutip dari M. Najih dan Soimin, Pengantar Hukum Indonesia Sejarah, Konsep Tata Hukum, dan Politik Hukum Indonesia (Malang: Setara Press, 2016), hlm. 86 
sistem politik yang memungkinkan negara berperan sangat aktif dalam mengambil hampir seluruh inisiatif dalam pembuatan kebijaksanaan negara. Produk hukum yang responsif adalah produk hukum yang mencerminkan rasa keadilan dan memenuhi harapan masyarakat. Produk hukum ortodoks/ elitis adalah produk hukum isinya lebih mencerminkan visi sosial elit politik, keinginan pemerintah, menjadi alat pelaksanaan ideologi dan program negara. ${ }^{242}$

Politik hukum satu negara berbeda dengan politik hukum negara yang lain. Menurut Sunaryati Hartono, faktor-faktor yang akan menentukan politik hukum tidak semata-mata ditentukan oleh apa yang kita cita-citakan atau tergantung pada kehendak pembentuk hukum, praktisi atau para teoretisi belaka, akan tetapi ikut ditentukan pula oleh kenyataan serta perkembangan hukum di lain-lain negara serta perkembangan hukum internasional. Perbedaan politik hukum suatu negara tertentu dengan negara lain inilah yang kemudian menimbulkan apa yang disebut dengan Politik Hukum Nasional. ${ }^{243}$

\section{Arah Politik Hukum Pengaturan Hak Atas Tanah Dalam UU No. 25 Tahun 2007 tentang Penanaman Modal}

Mengenai pertanahan, sesuai dengan isi yang terdapat dalam Pasal 33 ayat (3) Undang-Undang Dasar 1945, bahwa ruang lingkup bumi menurut Undang-Undang Pokok Agraria (UUPA) adalah permukaan bumi, dan tubuh bumi di bawahnya serta yang berada di bawah air. Permukaan bumi sebagai bagian dari bumi juga disebut tanah. Tanah yang dimaksudkan di sini bukan mengatur tanah dalam segala aspeknya, melainkan hanya mengatur salah satu aspeknya, yaitu tanah dalam pengertian yuridis yang disebut dengan hak penguasaan atas tanah. ${ }^{244}$

242 Mahfud MD, op.cit., hlm. 30-32

243 Sunaryati Hartono, Politik Hukum Menuju Satu Sistem Hukum Nasional, (Bandung; Alumni Press, 1991), hlm. 23. Lihat juga pada Mahfud MD, Ibid., hlm. 2

244 Urip Santoso, Hukum Agraria Kajian Komprehensif, (Jakarta: Kencana, 2012), hlm. 75 
Tanah termasuk aset yang selain mempunyai nilai ekonomis yang tinggi juga merupakan barang bagi kelangsungan kegiatan usaha penanaman modal (investasi). Ketersediaan tanah bagi penanaman modal (investasi) menjadi prasyarat mendasar. Sejak era feodalisme hingga kapitasme mutakhir, tanah merupakan modal yang memiliki nilai strategis dalam investasi. Pada masa feodalisme, tanah merupakan modal yang paling penting karena perekonomian bertumpu kepada luas tanah dan kesuburan tanah, maka diera kapitalisme mutakhir yang ditandai dengan pergerakan modal antar negara yang semakin cepat, sehingga tanah menjadi faktor yang menentukan dalam menarik investasi. 245

Upaya pemerintah untuk menarik investor khususnya investor asing dalam rangka mempercepat peningkatan investasi juga harus dibarengi dengan iklim usaha nasional yang kondusif (favourable) sifatnya. ${ }^{246}$ Upaya pemerintah dalam menciptakan iklim investasi yang kondusif adalah salah satunya dengan memberikan kemudahan pelayanan atau perizinan kepada perusahaan penanaman modal untuk memperoleh hak atas tanah. ${ }^{247}$ Hak atas tanah yang diberikan tersebut meliputi Hak Guna Usaha (HGU), Hak Guna Bangunan (HGB), dan Hak Pakai. Dalam Pasal 22 ayat (1) UU No. 25 Tahun 2007 tentang Penanaman Modal mengatur telah mengatur mengenai kemudahan pelayanan atau perizinan hak atas tanah yang dapat diberikan dan diperpanjang dimuka sekaligus dan dapat diperbarui kembali atas permohonan penanam modal, berupa:

245 Efrimol, “Kebijakan Pemerintah Tentang Pengaturan Mengenai Pertanahan dalam Penanaman Modal di Indonesia" dalam https://online-journal.unja.ac.id/index.php/jimih/article/view/533

246 Aminuddin Ilmar, Hukum Penanaman Modal di Indonesia (Jakarta: Kencana, 2006), hlm. 27

247 Pasal 21 Ayat (1) Undang-Undang No. 25 Tahun 2007 tentang Penanaman Modal 
a. Hak Guna Usaha dapat diberikan 95 tahun dengan cara diperpanjang dimuka sekaligus selama 60 Tahun dan dapat diperbarui 35 Tahun;

b. Hak Guna Bangunan diberikan 80 Tahun dengan cara diperpanjang dimuka sekaligus selama 50 Tahun dan dapat diperbarui 30 Tahun; dan

c. Hak Pakai diberikan 70 Tahun dengan cara diperpanjang dimuka sekaligus 45 Tahun dan dapat diperbarui selama 25 Tahun.

Ayat (2) pasal ini menerangkan hak atas tanah sebagaimana dimaksud pada ayat (1) dapat diberikan dan diperpanjang dimuka sekaligus untuk kegiatan penanaman modal, dengan persyaratan antara lain:

a. Penanaman modal dilakukan dalam jangka panjang dan terkait dengan perubahan struktur perekonomian Indonesia yang lebih berdaya saing;

b. Penanaman modal dengan tingkat risiko penanaman modal yang memerlukan pengembalian modal dalam jangka panjang sesuai dengan jenis kegiatan penanaman modal yang dilakukan;

c. Penanaman modal tidak memerlukan areal yang luas

d. Penanaman modal dengan menggunakan hak atas tanah negara; dan

e. Penanaman modal tidak mengganggu rasa keadilan masyarakat dan tidak merugikan kepentingan umum.

Selain itu, perpanjangan hak atas tanah tersebut dapat dihentikan atau dibatalkan oleh pemerintah jika perusahaan penanam modal menelantarkan tanah, merugikan kepentingan umum, menggunakan atau memanfaatkan tanah tidak sesuai maksud dan tujuan, serta melanggar ketentuan peraturan perundang-undangan dibidang pertanahan. ${ }^{248}$

248 Pasal 22 Undang-Undang No. 25 Tahun 2007 tentang Penanaman Modal 
Berbeda dengan UU No. 5 Tahun 1960 tentang Peraturan Dasar Pokok Agraria (UUPA) yang anti modal asing. Menteri Agraria Sadjarwo dalam pidatonya tanggal 14 September 1960 mengenai Naskah RUU Pokok Agraria dimuka Sidang Pleno DPR-GR antara lain menyatakan:

\begin{abstract}
“...Rancangan Undang-Undang ini selain akan menumbangkan puncak kemegahan penanaman modal asing yang telah berabad-abad memeras kekayaan dan tenaga bangsa Indonesia, hendaknya akan mengakhiri pertikaian dan sengketa-sengketa tanah antara rakyat dan kaum pengusaha asing, dengan aparat-aparatnya yang mengadu dombakan aparat-aparat pemerintah dengan rakyatnya sendiri, yang akibatnya mencetus sebagai peristiwa-peristiwa berdarah dan berkali-kali pentraktoran-pentraktoran yang sangat menyedihkan."
\end{abstract}

Kemudian, dalam pidatonya kembali selanjutnya ia mengatakan bahwa "modal asing hanya mempunyai sifat sementara, sesuai dengan apa yang dibutuhkan oleh pembangunan semesta berencana. Dengan lahirnya Undang-Undang Pokok Agraria ini, secara tidak langsung telah mengeliminasi investasi asing." 249

Ketentuan pengaturan Hak atas tanah dalam UU Penanaman Modal (UUPM) berbeda dengan ketentuan yang ada dalam UUPA. Berdasarkan UU No.5 Tahun 1960 (UUPA), hak atas tanah dapat diberikan paling lama 35 tahun dan setelah itu dapat diperpanjang 25 tahun lagi. Namun seiring berjalannya waktu, jangka waktu ini tidak memadai lagi untuk investor. Dinegara-negara lain, seperti Malaysia, Singapura, Vietnam dan Cina hak atas tanah untuk investor berkisar antara 75 tahun sampai dengan 90 tahun. 250

249 Sadjarwo dalam Boedi Harsono, Hukum Agraria Indonesia (Jakarta, Djambatan, 2003), hlm. 607-614 Dikutip dari Erman Rajagukguk, Hukum Investasi Penanaman Modal Asing (PMA) dan Penanaman Modal Dalam Negeri (PMDN), (Jakarta: Rajagrafindo Persada, 2019), hlm. 117-118

250 Erman Rajagukguk., loc.cit 
Seiring berjalannya waktu Indonesia kembali membutuhkan Investasi asing. Pada tahun 1996, pemerintah Indonesia berusaha untuk memodifiasi hak atas tanah bagi investor dengan mengeluarkan Peraturan Pemerintah No. 40 Tahun 1996 tentang Hak Guna Usaha, Hak Guna Bangunan dan Hak Pakai Atas Tanah. Dalam PP No. 40 Tahun 1996 diatur mengenai pembaharuan hak atas tanah di atas tanah yang sama setelah berakhirnya jangka waktu perpanjangan hak atas tanah. Misalnya pada ketentuan Hak Guna Usaha, Menurut Pasal 8 ayat (1) menyebutkan bahwa "HGU dapat dapat diberikan untuk jangka waktu paling lama 35 tahun dan dapat diperpanjang paling lama 25 tahun". Pernyataan dalam Pasal 1 masih sejalan dengan UUPA, namun ada pernyataan tambahan pada Pasal 8 ayat (2), yaitu "sesudah jangka waktu Hak Guna Usaha dan perpanjangannya sebagaimana dimaksud dalam ayat (1) berakhir, kepada pemengang hak dapat diberikan pembaharuan Hak Guna Usaha di atas tanah yang sama".

Pernyataan pasal a quo dinilai telah melenceng dari UUPA, sehingga apabila dilakukan pembaharuan Hak Guna Usaha maka jangka waktunya dua kali jangka waktu HGU dan dua kali perpanjangan HGU. Selain itu, pada Pasal 11 PP No. 40 Tahun 1996 menyatakan bahwa:

a. Untuk kepentingan penanaman modal, permintaan perpanjangan atas pembaharuan HGU dapat dilakukan sekaligus dengan membayar uang pemasukan yang ditentukan untuk itu pada saat pertama kali mengajukan permohonan HGU.

b. Dalam hal pemasukan telah dibayar sekaligus sebagimana dimaksud dalam ayat (1), untuk perpanjangan atau pembaharuan HGU hanya dikenakan biaya administrasi yang besarnya ditetapkan oleh Menteri

Ketentuan dalam PP No. 40 Tahun 1966 sejalan dengan UU Penanaman Modal yang mengatur mengenai 
"dapat diperbarui dan diperpanjang dimuka sekaligus". Namun, dalam aturan tersebut pemerintah terlihat lebih memberikan keleluasaan terhadap para investor dalam hal penguasaan lahan jika dibandingkan dengan UUPA. Banyak kalangan menilai bahwa pembaharuan Hak Atas Tanah bertentangan dengan semangat UUPA karena pemanfaatan lahan dan pengelolaan lahan adalah untuk kepentingan investor. Setelah habisnya jangka waktu dan perpanjangan jangka waktu kemudian terdapat pembaharuan kembali diatas yang sama adalah salah satu contoh kepentingan ekonomi yang terakomodir melalui kekuasaan politik yang hendak melanggengkan kepentingannya terhadap pemanfaatan dan pengelolaan lahan. Kepentingan ekonomi melalui kekuasaan politik sudah menyusup dalam pembuatan perangkat yuridis sehingga kebijakan tersebut pada akhirnya akan menampikkan keadilan dan harapan untuk sebesar-besarnya bagi kemakmuran rakyat indonesia. ${ }^{251}$

Namun apabila dianalisis kembali, istilah pembaharuan hak yang didapati dalam PP No. 40 Tahun 1996 dan UU No. 25 Tahun 2007 tentang Penanaman Modal tidak sepenuhnya bertentangan dengan UUPA berdasarkan dua alasan. Pertama, UUPA sendiri tidak mengatur apakah yang akan terjadi setelah HGU dan HGB itu berakhir setelah diperpanjang jangka waktunya kecuali menyebutkan bahwa HGU dan HGB akan hapus apabila jangka waktu berakhir. Logikanya adalah, dengan hapusnya HGU atau HGB tersebut, di atas tanah bekas HGU dan HGB yang statusnya kini menjadi tanah negara dapat diberikan sesuatu hak atas tanah, termasuk kemungkinan diberikan HGU dan HGB baru, baik kepada pemohon baru, maupun pemohon bekas pemegang hak.

${ }^{251}$ Ni Ketut Sri Parwati dan Sudjito, "Politik Hukum Pemberian Hak Guna Usaha Setelah Berlakunya Undang-Undang Penanaman Modal Nomor 25 Tahun 2007 Dan Implikasinya Terhadap Nasib Petani", Mimbar Hukum, Edisi No. 1 Vol. 21, (2009), hlm. 146 
Jika pemohonnya adalah bekas pemegang hak yang lama yang masih memenuhi persyaratan, maka istilah yang lebih tepat digunakan adalah pembaharuan hak, mengingat bahwa HGU atau HGB itu tidak dimohon untuk pertama kali, tetapi dimohon menjelang berakhirnya perpanjangan waktu HGU atau HGB tersebut. Kedua, Penggunaan istilah pembaharuan hak, yang tentunya juga masih membuka kemungkinan untuk diberi perpanjangan apabila syarat-syaratnya dipenuhi, adalah sesuai dengan metode interpretasi terhadap Pasal 29 dan Pasal 35 UUPA sebagai salah satu cara pembangunan hukum dengan jalan penemuan hukum (rechtsvinding). ${ }^{252}$

Namun, Mahkamah Konstitusi dalam putusannya No. 21-22/PUU-V/2007 menyatakan bahwa kata-kata "diperpanjang dimuka sekaligus" dalam Pasal 22 UU No. 25 Tahun 2007 tentang Penanaman Modal tidak mempunyai kekuatan hukum. Alasannya antara lain bertentangan dengan UU Dasar 1945 sebab solusi yang diberikan pemerintah dalam upaya peningkatan investasi dengan memberikan kemudahan-kemudahan bagi investor asing secara ekstrim dinilai tidak adil. Oleh karena itu, Pasal 22 ayat (1) dalam UUPM tersebut tidak berlaku lagi, dan ketentuan tentang jangka waktu HGU, HGB, dan Hak Pakai yang dapat diperoleh investor kembali kepada ketentuan dalam Undang-Undang No. 5 Tahun 1960 tentang Pokok-Pokok Agraria. 253

Undang-Undang Pokok Agraria harus kembali dinaikan dan mempertegas posisinya sebagai undang-undang pokok keagrarian di Indonesia yang berdasarkan pada Pasal 33 Undang-Undang Dasar 1945. Telepas dengan kelemahan yang terdapat dalam Undang-Undang Pokok Agraria, maka UUPA ini harus menjadi acuan dasar dalam pembuatan undang-undang lain

${ }^{252}$ Erman Rajagukguk, Hukum Investasi Penanaman Modal...op.cit., hlm. 120

253 Putusan 21, 22 PUU-2007 Penanaman Modal, dalam https://ditjenpp.kemenkumham.go.id 
yang terkait dengan pengatuaran hak atas tanah dalam hal ini adalah Undang-Undang No. 25 Tahun 2007 tentang Penanaman Modal. Pasal 33 UUD 1945 menjadi landasan dalam pembentukan UUPA dan menjadi acuan utama negara dalam menguasai dan mengatur pemanfaatan tanah dan sumber daya alam yang disebut sebagai hak menguasai negara.

Hak menguasai negara adalah hak rakyat pada tingkat negara sebagai organisasi tertinggi sehingga negara tidak memiliki kewenangan untuk menjual atau menggadaikan tanah. Masalah agraria akan muncul ketika kewenangan hak menguasi negara diperhadapkan dengan hak milik individu dan hak komunal atau hak ulayat. Rakyat yang sudah ada sebelum negara ada mempunyai hak yang melekat pada dirinya seperti hak hidup, hak ekonomi, hak politik, hak sosial budaya dan hak ekologis. ${ }^{254}$

Hak menguasai negara dalam Pasal 33 UUD termuat dalam ayat (2) dan (3) yang menyatakan, bahwa:

“(2) Cabang-cabang produksi yang penting bagi Negara dan yang menguasai hajat hidup orang banyak dikuasai oleh Negara.

(3) Bumi dan air dan kekayaan alam yang terkandung di dalamnya dikuasai oleh Negara dan dipergunakan untuk sebesar-besarnya kemakmuran rakyat."

Pada implementasinya Hak Menguasai Negara (HMN) mengalami multitafsir sesuai dengan kepentingannya masing-masing sesuai bidang. Mahkamah Konstitusi kemudian memberikan tafsir baru, bahwa Hak Menguasai Negara (HMN) dimana negara dituntut mempunyai kewenangan dalam 4 (empat) hal, yaitu:

254 Winahyu Erwiningsih, Hak Menguasai Negara Atas Tanah, Cetakan Pertama (Yogyakarta: Total Media Press, 2009), hlm. 66 
mengatur (regelendaad), mengurus (bestuurdaad), mengelola (beheersdaad), dan mengawasi (toezichthoundensdaad). ${ }^{255}$

Pemberian hak atas tanah kepada investor yang merupakan kewenangan negara berdasarkan Hak Menguasai Negara. Namun, pengaturan hak atas tanah dalam UU Penanaman Modal dinilai tidak sejalan dengan ketentuan yang ada dalam UUPA. Kondisi ini sempat menciptakan kesenjangan dan memicu berbagai permasalahan tanah dalam kegiatan investasi di Indonesia. Kesenjangan ini ditandai oleh ketidak konsistenan antara amanat dan semangat dari prinsip-prinsip UUPA dalam penjabarannya dan dengan peraturan pelaksananya. Sejumlah peraturan pelaksana UUPA dan peraturan terkait investasi dalam UUPM yang mencerminkan insinkronisasi adalah: 256

a. Pemberian jangka waktu hak atas tanah yang relatif lebih lama kepada pengusaha atau investor disektor seperti pertanian, perkebunan, kehutanan, serta properti

b. Ketentuan yang mendorong pemahaman bahwa tanah merupakan komoditas dan mengabaikan nilai lainnya, seperti fungsi sosial dan nilai religius

c. Ketentuan yang mendorong pengabaian terhadap hak-hak tradisional atas tanah masyarakat khususnya tanah adat

d. Peraturan yang memberi peluang terjadinya pengabaian dan kemerosotan kesejahteraan pemegang hak atas tanah yang terkena pengambilalihan untuk kepentingan investasi dalam rangka pembangunan

Perkembangan gagasan politik agaria Indonesia menemukan bentuk kostitusionalnya yang dirumuskan dalam Pasal 33 UUD 1945 dan UUPA. Politik agraria

255 A.P Parlindungan, Komentar Atas Undang-Undang Pokok Agraria, (Bandung: Mandar Maju, 2008) hlm.44

256 Sri Hajati, "Pengaturan Hak Atas Tanah dalam Kaitannya dengan Investasi" Desertasi (Surabaya: Fakultas Hukum Universitas Airlangga, 2003) hlm. 11 
konstitusional jelas mencerminkan pilihan pada (neo) populisme. Disamping itu UUPA juga berkarakter anti ruah tanah, anti modal asing yang sifatnya mengeksploitasi kekayaan bangsa Indonesia sedemikian rupa sehingga hal tersebut sangat merugikan kepentingan bangsa Indonesia. UUPA juga menentang strategi sosialis yang dianggap "meniadakan hak-hak individu atas tanah" tetapi hak atas tanah tersebut mempunyai fungsi sosial. ${ }^{257} \mathrm{Hal}$ ini bisa kita lihat bahwa secara umum strategi politik agraria dapat dibedakan menjadi 3 (tiga) ciri ideal yang menjadi pembeda antara satu sistem dengan sistem lainnya, yaitu:

a. Penguasaan tanah;

b. Tenaga kerja dan

c. Tanggung jawab atau pengambilan keputusan mengenai produksi, akumulasi dan investasi. 258

Politik hukum yang terkandung dalam Undang-Undang No. 5 Tahun 1960 (UUPA) berkarakter responsif ${ }^{259}$, yang mengakui hak individu atas tanah, tetapi hak atas tanah tersebut memiliki fungsi sosial. Melalui "Hak Menguasai Negara", pemerintah mengatur agar tanah-tanah tersebut digunakan untuk sebesar-besarnya kemakmuran rakyat. Namun, seiring dengan berjalannya waktu pemerintah kembali harus mengambil langkah dalam program pembangunannya, salah satunya dengan menarik modal sebanyak mungkin dengan mengundang para investor khususnya asing untuk masuk ke Indonesia.

257 Pasal 6 Undang-Undang No. 5 Tahun 1960 tentang Peraturan Dasar Pokok Agraria

258 Sri Hajati, op.cit., hlm. 47-48

259 UUPA dikatakan Responsif, pertama UUPA disahkan berdasarkan rancangan yang telah disiapkan oleh periode sebelumna. Kedua, UUPA membongkar dasar-dasar kolonialisme yang ditentang oeh semua pemerintah tanpa tergantung konfigurasi politiknya. Ketiga, UUPA memuat materi yang tidak menyangkut hubungan kekuasaan. Keempat, tidak semata-mata memuat bidang hukum administrasi negara tetapi juga keperdataan. Moh. Mahfud MD, op.cit., hlm. 355-356 
Terhadap wewenang yang dimiliki pemerintah dalam hal penguasaan tanah untuk kegiatan investasi. UUPA yang sebelumnya berkarakter responsif atau populis, namun karena interpretasi pemerintah dalam bentuk peraturan perundang-undangan yang lain untuk keperluan pragmatis dalam rangka pelaksanaan program pembangunan (investasi) menjadikan UUPA berwatak konservatif. ${ }^{260}$ Namun, dengan adanya putusan Mahkamah Konstitusi dalam putusannya No. 21-22/PUU-V/2007, tidak membuat sepenuhnya karakter produk hukum pertanahan kembali pada watak yang responsif, mengingat pada pelaksanaan PP No. 40 Tahun 1966 yang masih sering menuai konflik pertanahan dibidang HGU dan hal ini tidak sesuai dengan amanah yang terkandung dalam Pasal 33 UUD 1945.

Sedangkan politik hukum pengaturan hak atas tanah yang terkandung dalam Undang-Undang No. 25 Tahun 2007 tentang Penanaman Modal (UUPM) lebih mencerminkan ke arah politik otoriter, sebab dalam pembuatan perundang-undangan tersebut di mana negara berperan sangat aktif dalam mengambil hampir seluruh inisiatif dalam pembuatan kebijaksanaan negara. Sebagai akibatnya, produk hukum yang dihasilkan lebih bersifat ortodoks di mana isinya lebih mencerminkan visi sosial elite politik, mencerminkan keinginan pemerintah, dan program negara.

Dalam pandangan banyak kalangan, undang-undang ini dinilai sangat pro-investor asing. Ini dapat dilihat pada fakta-fakta yang menyangkut hak atas tanah, jika pada undang-undang sebelumnya hak atas tanah bagi investor asing hanya berkisar 30-an tahun, melalui undang-undang ini penguasaan tanah diperlonggar hingga 60 tahun. Demikian juga dengan hak guna usaha yang diperlonggar menjadi 65 tahun, hak guna bangunan menjadi 60 tahun, dan hak pakai hingga 70 tahun. Selain itu, undang-undang ini juga membuka bidang-bidang usaha yang dulunya 
tertutup untuk asing. Bahkan asing dapat menanamkan investasinya dibidang penanaman padi. ${ }^{261}$

\section{Implikasi Politik Hukum Pertanahan Dalam Upaya Peningkatan Investasi Terhadap Kesejahteraan Ekonomi Rakyat}

Dalam perjalanan UU Pokok Agraria sampai dengan saat ini, ada lima masalah dibidang pertanahan yang sering mencuat ke permukaan, yaitu:

1. Fungsi sosial tanah (Pasal 6)

2. Batas maksimum pemilikan tanah (Pasal 7)

3. Pemilikan tanah guntai262 (Pasal 10)

4. Monopoli pemilikan tanah (Pasal 13)

5. Penetapan ganti rugi tanah (Pasal 18)

Kelima hal ini baik secara langsung maupun tidak langsung telah memicu munculnya berbagai bentuk konflik pertanahan yang sulit diselesaikan. Masalah menjadi semakin rumit, karena gencarnya aktivitas pembangunan menyebabkan terlupakannya unsur keadilan dibidang pertanahan. Penerapan Pasal 6 UUPA tentang fungsi sosial tanah, misalnya masih sering kontras dalam praktik dilapangan. Kebijakan pertanahan dalam usaha-usaha dibidang agraria seperti pemberian hak atas tanah oleh pemerintah kepada investor sebagaimana diatur dalam Pasal 22 Undang-Undang No. 25 Tahun 2007 tentang Penanaman Modal dengan jangka waktu penggunaan tanah yang relatif lebih lama memberikan dampak negatif bagi perkembangan ekonomi rakyat, ${ }^{263}$ khususnya pada masyarakat petani.

261 Yoseph Umarhadi, Jebakan Liberalisasi: Pragmatisme, Dominasi Asing, dan Ketergantungan Ekonomi Indonesia, Cetakan Pertama (Yogyakarta: Cakrawala Institute, 2010) hlm. 43

${ }^{262}$ Tanah guntai adalah tanah yang terletak disuatu desa, tetapi dimiliki oleh seseorang lain yang tidak bertempat tinggal didesa tersebut. Tanah seperti ini seringkali ditelantarkan sehingga pada asasnya sangat bertentangan dengan jiwa UUPA. Lihat Peraturan Pemerintah No. 224 Tahun 1961

263 Konsep ekonomi rakyat menghendaki pembagian penguasaan sumberdaya ekonomi yang lebih luas dan merata serta tepat sasaran agar 
Selain itu, kebijakan pemerintah melalui PP No. 40 Tahun 1966 untuk pengaturan Hak Guna Usaha, sampai dengan saat ini masih banyak menyisakan konflik yang belum terselesaikan. Munculnya kebijakan baru seperti UU Penanaman Modal akan semakin menambah beban konflik pertanahan. Beberapa contoh konflik antara masyarakat dengan pengusaha atau investor diantaranya adalah, sebagai berikut:

1. Kasus yang terjadi di Desa Sorokonto Wetan, Pageruyung, Kendal, Jawa Tengah. Konflik terjadi antara warga petani dengan PT. Semen Indonesia. Berawal ketika 3 petani Surokonto dituntut karena telah mempergunakan lahan milik PT. Sumurpitu yang telah beralih HGU nya kepada PT. Semen. Sebelumnya pada tahun 1972 tanah tersebut adalah HGU milik PT. Sumurpitu yang telah habis jangka waktunya kemudian diperpanjang pada tahun 1998. Ternyata fakta dilapangan menunjukkan, bahwa tanah tersebut tidak pernah dimanfaatkan oleh pihak perusahaan sejak tahun 1972 dan menjadi terlantar. Disisi lain tanah pertanian garapan masyarakat tersebut merupakan tanah turun-temurun (adat) semenjak tahun 1950. Secara yuridis bahwa tanah yang HGU nya tidak dimanfaatkan maka secara hukum dianggap terlantar dan tanah tersebut wajib didistribusikan negara kepada masyarakat melalui reforma agraria. Namun, sebelum kasus ini sampai pengadilan, keputusan pemerintah yang langsung memberikan perpanjangan HGU tanpa observasi dilapangan dinilai tidak berpihak kepada kemaslahatan masyarakat dan cenderung mengabaikan prosedur yang ada hingga menyebabkan konflik berkepanjangan. ${ }^{264}$

2. Kasus Perkebunan Kakao PT. Delta Subur Permai, Kabupaten Luwuk, Sulawesi Tengah tentang pengambilan tanah masyarakat Seseba atas nama izin Hak Guna Usaha

kemakmuran menjadi milik setiap warga negara, bukan milik segelintir orang. Julius Bobo, Transformasi Ekonomi Rakyat (PT. Pustaka Cidesindo, 2003), hlm. 81

264 https://kpa.or.id/media/baca2/opini/8/Polemik_Pembangunan_Pabri k_Semen_Rembang_dan_Jerat_UU_P3H_untuk_Petani Diakses pada 20 Juni 2020 
(HGU) di dataran Banggai oleh perusahaan untuk perkebunan kakao. Konflik muncul karena lahan perkebunan kakao milik masyarakat diambil paksa oleh perusahaan, Bahkan beberapa lokasi yang menurut masyarakat bukanlah bagian HGU, akan dijadikan lahan inti milik perusahaan. penolakan petani dijawab intimidasi dari perusahaan, dan berujung penangkapan petani oleh kepolisian. ${ }^{265}$

3. Kasus yang terjadi di Sulawesi Tengah antara warga sebagai pemilik perkebunan kelapa sawit dengan PT. Mamuang terkait sengketa lahan perkebunan. Konflik terjadi disebabkan karena PT. Mamuang perusahaan kelapa sawit mengambil paksa lahan perkebunan dan mengklaim tanah kebun milik Hemsi (pemilik kebun) tersebut sebagai wilayah Hak Guna Usaha (HGU) perusahaan. ${ }^{266}$

Dengan demikian, peraturan dalam PP No. 40 Tahun 1966 telah menindas rasa keadilan masyarakat petani yang jelas-jelas membutuhkan lahan untuk kesejahteraan hidup mereka. Para pemodal diuntungkan oleh kebijakan pemerintah yang lebih condong pada pertumbuhan ekonomi. Dengan dalih demi pembangunan, tanah-tanah garapan petani atau tanah milik masyarakat adat diambil alih oleh para pemodal yang memanfaatkan peluang pengalihan hak atas tanah yang terdapat pada UU Penanaman Modal. Dengan demikian, muncul sumber konflik baru yaitu antara usaha petani kecil dengan para pemodal besar, ironisnya tidak hanya didukung oleh perangkat yuridis dalam peraturan perundang-undangan tetapi juga aparat keamanan. ${ }^{267}$

Kemudian apabila mengacu pada Peraturan Menteri Pertanian No. 26/Permentan/05.140/2/2007 yang dikeluarkan

265

https:// www.mongabay.co.id/2013/11/30/tolak-sawit-petani-banggai-ditangkapi $\angle$ Diakses pada 25 Juni 2020

266

https:// www.tirto.id/warga-gugat-t-mamuang-terkait-sengketa-lahan-perkebunan Diakses pada 25 Juni 2020

267 Ni Ketut Sri Parwati dan Sudjito, op.cit., hlm. 152 
pada 28 Februari 2007 menetapkan satu perusahaan hanya diizinkan mengembangkan areal kelapa sawit dalam satu kawasan maksimal 100.000 ha. Sedangkan untuk perusahaan perkebunan negara, koperasi usaha perkebunan, perusahaan perkebunan yang sudah "go public", bisa mengembangkan areal perkebunan kelapa sawit melebihi 100.000 ha dalam satu kawasan. Begitu juga pengembangan perkebunan kelapa sawit diprovinsi Papua diizinkan sampai lebih dari 100.000 ha. ${ }^{268}$

Meskipun peraturan tersebut telah mengakomodir batasan luas tanah pertanian, dalam praktik dilapangan sedikit demi sedikit terkikis oeh sifat kapitalistik para investor atau pemodal. Hal ini juga yang menimbulkan konflik kewenangan antara instansi pemerintah yang terkait dengan pertanahan yaitu Badan Pertanahan Nasional (BPN) disatu pihak dengan Kementrian Pertanian, Kehutanan, dan kementrian terkait lainnya. Sumber konfliknya adalah perbedaan cara dalam mewujudkan amanah Pasal 33 ayat (3) UUD 1945. Kemudian disatu pihak terdapat kebijakan yang mengembangkan cara pemerataan penguasaan dan pemanfaatan tanah untuk mewujudkan kemakmuran rakyat, sedangkan yang lain mengembangkan cara konsentrasi tanah untuk mewujudkan arah politik hukum pertanahan tersebut. ${ }^{269}$

Kepentingan-kepentingan politik dan ekonomi berpengaruh besar pada struktur hukum yang ada yang pada akhirnya juga merusak budaya hukum yang ada. Politik hukum pertanahan yang kapitalistik dan liberal yang digunakan selama ini memang disatu sisi telah menimbulkan kemajuan dalam pembangunan di sektor strategis seperti sektor pertanian, perkebunan, dan properti di Indonesia. Namun dibalik keberhasilan atau dampak positif tersebut, politik hukum pertanahan juga mendatangkan dampak negatif, di antaranya adalah terjadinya kesenjangan dalam penguasaan

${ }^{268}$ Erman Rajagukguk, Hukum Investasi Penanaman Modal Asing (PMA)... op.cit., hlm.117

${ }^{269}$ Nurhasan Ismail, “Arah Politik Hukum Pertanahan dan Perlindungan Kepemilikan Tanah Masyarakat", Jurnal Rechtsvinding, Edisi No. 1 Vol. 1 (2012) hlm. 45 
dan pemanfaatan sumber daya alam berupa tanah di mana ada ketimpangan dalam distribusi penguasaan dan pemilikan tanah. Ada sekelompok kecil subjek yang menguasai dan memanfaatkan tanah yang sangat luas dan besar, namun sebagian besar dari warga masyarakat hanya menguasai tanah dan memanfaatkan bagian sumber daya yang relatif terbatas.

Selain itu, politik hukum pertanahan juga telah mendorong terjadinya konflik struktural atara kelompok subjek yaitu: 270

1. Berlangsung dan berkembangnya konflik struktural yang dipicu oleh kebijakan negara yang mendorong terjadinya kesenjangan sosial ekonomi dan kemiskinan didaerah yang kaya akan sumberdaya alam. Konflik struktural melibatkan kelompok masyarakat lokal baik atas dasar kebutuhan maupun historis yang mempunyai keterkaitan dengan objek konflik, para pelaku usaha atau investor yang memperoleh akses dan aset dalam skala besar, dan pemerintah sebagai pelaksana kewenangan negara dalam pembuatan kebijakan dan pendistribusian akses dan aset. Jumlah dan intensitas konflik terus berlangsung sejalan dengan rendahnya tingkat harapan masyarakat akan kemungkinan terjadinya perubahan kebijakan yang akan memberikan perlindungan hukum terhadap akses memperoleh tanah atau hak atas tanah. Akibatnya banyak masyarakat lokal dalam kondisi tanpa harapan dan perubahan mengungkapkannya dalam bentuk-bentuk konflik. Namun ketika bentuk konflik tersebut tidak mendapatkan respons postif dari negara, konfliknya berubah menjadi tindakan kekerasan. ${ }^{271}$

2. Konflik struktural antara pemilik tanah yang terkena pengadaan tanah untuk kepentingan umum dengan instasi pemerintah yang memerlukan tanah. Konflik ini akan terus berlangsung karena disatu sisi pemilik tanah merasa tidak

270 Nurhasan Ismail, Ibid., hlm. 47-48

271 Seperti yang terjadi konflik tanah di Pasuruan, Kebumen, Lampung, Sumatra Utara, Kalimantan, Sulawesi Barat, NTB, dan Papua. Pemicunya adalah adanya kesenjangan terhadap pemberlakuan kebijakan pertanahan yang berat sebelah dan jauh meninggalkan ruh UUPA 
mendapatkan perlindungan hukum terhadap hak-hak individunya dengan rendahnya ganti rugi yang diberikan. Namun disisi lain, instansi pemerintah didorong untuk mencari cara untuk mempercepat perolehan tanah termasuk cara yang represif seperti konsinyasi ganti rugi ke pengadilan meskipun tanpa persetujuan pemilik tanah tanpa berupaya memenuhi harapan pemilik tanah mendapatkan ganti rugi yang menjamin keberlangsungan kesejahteraan mereka sebagaimana yang dikehendaki oleh Perpres No. 36 Tahun 2005 tentang Pengadaan Tanah Bagi Pelaksanaan Pembangunan Untuk Kepentingan Umum. ${ }^{272}$

Kebijakan pemberlakuan UUPM dapat dikatakan belum menyiapkan struktur hukum dengan sumber daya yang memadai dan berkompeten untuk terlaksananya kebijakan tersebut sebagaimana dikehendaki oleh amanat Pasal 33 ayat (3) UUD 1945. Bila UUPM merupakan konsesus sepihak dari pemerintah tanpa peran serta masyarakat, maka akan terjadi penyelewengan-penyelewengan yang berakhir pada penindasan keadilan masyarakat dan merusak tatanan sosial budaya hukum yang ada. Apabila keadaan seperti ini dibiarkan hingga muncul sebuah konflik tanpa penyelesaian yang berarti, maka harapan untuk terwujudnya pemerataan ekonomi hanya sebatas slogan dan tidak pernah menyentuh lapisan masyarakat bawah (petani) karena terganjal kepentingan para pemodal.

Alternatif untuk mengurangi atau bahkan meniadakan persoalan tentang tanah sebagai dampak negatif dari politik hukum pertanahan, maka perlu pemikiran untuk mengembangkan politik hukum pertanahan yang

272 Implikasi praktis di lapangan ternyata aturan tersebut masih menuai kritik dari berbagai pihak karena masih ada kesan dominasi pemerintah terhadap penentuan politik kebijakan penatagunaan tanah dalam konteks investasi. Sebagaimana kasus pengalihan "paksa" hak atas tanah yaitu kasus SukoliloSurabaya dan kasus Kedung Ombo di Jawa Tengah dan berbagai kasus tanah lainnya yang penyelesaiannya relatif memerlukan waktu cukup lama dan memakan korban jiwa dan material. I Gede A.B Wiranto, loc.cit 
"prismatik". 273 Sebagai hukum prismatik, prinsip-prinsip UUPA dijabarkan dari 2 (dua) kelompok nilai sosial yaitu modern dan tradisional sesuai dengan kemajemukan masyarakat Indonesia. Melalui prinsip-prinsip hukum yang diramu dari perpaduan antara nilai sosial modern dan tradisional dimaksudkan agar pengaturan penguasaan dan pemanfaatan tanah mengarah pada terciptanya kemakmuran yang merata bagi semua orang dan kelompok masyarakat.

Melalui perpaduan prinsip-prinsip hukum tersebut, UUPA disatu sisi hendak mendorong kemajuan ekonomi pertanian dan industri dengan memberikan hak atas tanah secara individual kepada setiap orang atau perusahaan dalam skala besar (investor) dan mewajibkan kepada mereka produksi secara optimal. Namun disisi lain, UUPA berusaha mencegah terjadinya dampak sosial ekonomi politik negatif dari proses pencapaian kemajuan dengan membebankan fungsi sosial hak atas tanah, kewajiban konservasi tanah, perlakuan khusus bagi kelompok yang lemah, pewadahan dalam koperasi bagi usaha skala besar, dan larangan monopoli..$^{274}$

Arah politik hukum pertanahan yang prismatik ini dimaksudkan untuk mewujudkan dan mendorong kemajuan perekonomian indonesia melalui penataan penguasaan dan pemanfaatan tanah namun tetap memberikan perhatian terhadap kelompok yang lemah secara sosial, ekonomi dan politik dengan memberikan akses kepada mereka yang mempunyai tanah. Untuk mewujudkan tujuan tersebut, politik hukum pertanahan prismatik mendasarkan pada prinsip hukum tertentu sebagai dasar pengembangan kebijakan pertanahan yaitu: 275

273 Nurhasan Ismail, Perkembangan Hukum Pertanahan: Pendekatan Ekonomi Politik (Jakarta: HUMA dan Magister Hukum UGM, 2007) hlm. 3

274 Ibid., hlm. 4.

275 Ana Silviana, "Politik Hukum Pertanahan Prismatik Mewujudkan Kesejahteraan Rakyat Dalam Kepemilikan Tanah", 2018 hlm. 14-15 Lihat juga dalam Nurhasan Ismail, Perkembangan Hukum Pertanahan... op.cit., hlm. 12 
1. Prinsip Keberagaman Hukum dalam Kesatuan

Prinsip ini menekankan pada penghormatan terhadap perbedaan hukum yang terdapat dalam masyarakat dibidang pertanahan khususnya dengan memberikan pengakuan dan penghormatan terhadap masyarakat hukum adat sebagaimana dikehendaki oleh pasal 18 B ayat (2) UUD 1945, yang merumuskan bahwa:

"Negara mengakui dan menghormati kesatuan-kesatuan masyarakat hukum adat beserta hak-hak tradisionalnya sepanjang masih hidup dan sesuai dengan perkembangan masyarakat dan prinsip Negara Kesatuan Republik Indonesia yang diatur dalam undang-undang."

Namun pengakuan dan penghormatan tersebut harus sesuai dengan kepentingan bangsa dan negara sebagai konsekuensi dari komitmen kebangsaan yang sudah disepakati.

2. Prinsip Persamaan Atas Dasar Ketidaksamaan

Prinsip ini menekankan bahwa untuk mewujudkan adanya persamaan secara sosial ekonomi terutama di masyarakat ekonomi majemuk seperti indonesia harus dikembangkan kebijakan pertanahan yang mendasarkan pada realita ketidaksamaan (perbedaan) di antara kelompok-kelompok masyarakat. Bagi kelompok masyarakat yang sudah mampu, dapat mempunyai tanah berdasarkan persyaratan dan prosedur yang umum berlaku. Namun bagi kelompok masyarakat yang lemah harus ada intervensi negara untuk memberikan kemudahan dan fasilitas pemberian tanah. Dengan adanya perbedaan perlakuan tersebut, semua kelompok akan mencapai persamaan kondisi sosial ekonomi. 
3. Prinsip Mengutamakan Keadilan dan Kemanfaatan di Atas Kepastian Hukum;

Prinsip ini menekankan bahwa mewujudkan pemerataan, penguasaan dan pemilikan tanah merupakan kebijakan yang lebih memenuhi rasa keadilan dan kemanfaatan bagi masyarakat. Berdasarkan prinsip ini, menumpuk penguasaan dan pemanfaatan tanah merupakan tindakan yang tidak adil dan tidak bermanfaat karena hanya menimbulkan kecemburuan sosial dan penelantaran tanah yang merugikan kepentingan bersama.

4. Prinsip Diferensiasi Fungsi dalam Keterpaduan

Prinsip ini menekankan bahwa disatu sisi pembagian kewenangan di antara instansi pemerintah merupakan suatu kebutuhan untuk terjadinya efektifitas pencapaian tujuan bersama. Oleh karenanya, harus dicegah terjadinya egoisme sektoral yang menyebabkan terjadinya hambatan terhadap pencapaian tujuan bersama. Untuk itu, keterpaduan di antara instansi pemerintah menjadi keniscayaan agar kebijakan yang di kembangkan tidak saling tumpang tindih dan saling menafikan.

Merujuk pada pilihan kebijakan pertanahan dalam kaitannya dengan penguasaan tanah adalah keseimbangan antara memberikan ruang gerak bagi berkembangnya investasi sekaligus melindungi dan memberdayakan masyarakat dalam memenuhi kebutuhanya atas tanah. ${ }^{276}$ Kebijaksanaan pertanahan harus mampu menjamin keadilan untuk mendapat akses dalam perolehan dan pemanfaatan tanah. Implementasi pada keempat prinsip dalam politik hukum pertanahan Prismatik harus tertuang dan dijabarkan dalam peraturan perundang-undangan yang mengatur mengenai pertanahan yang tentunya tetap bersumber pada UUPA dan Pasal 33 ayat 3 UUD 1945.

${ }^{276}$ Maria W. Soemarjono, "Tanah dari Rakyat, oleh Rakyat, dan untuk Rakyat", Media Transparansi Online, Edisi 2 November 1989 


\section{Penutup}

Salah satu upaya pemerintah untuk menarik investor adalah dengan memberikan kemudahan investasi kepada perusahaan penanaman modal untuk memperoleh hak atas tanah yang dituangkan dalam Pasal 21 dan Pasal 22 UU Penanaman Modal. Namun, dalam aturan tersebut pemerintah lebih memberikan keleluasaan terhadap investor dalam hal penguasaan tanah jika dibandingkan dengan Undang-Undang Nomor 5 Tahun 1960 (UUPA). Dalam hal ini mengenai jangka waktu penguasaan tanah, pembaharuan, dan pemberian "dapat diperpanjang dimuka sekaligus". Ketentuan tersebut sejalan dengan PP No. 40 Tahun 1966. Inilah yang kemudian memicu berbagai permasalahan tanah dalam kegiatan investasi di Indonesia. Politik hukum yang terkandung dalam UUPA pada awalnya berkarakter responsif. Namun karena interpretasi pemerintah terkait pertanahan dalam bentuk peraturan perundang-undangan yang lain untuk keperluan pragmatis dalam rangka pelaksanaan program pembangunan yang dinilai pro investor menjadikan UUPA berwatak konservatif dalam masanya. Meskipun putusan Mahkamah Konstitusi No. 21-22/PUU-V/2007 telah membatalkan Pasal 22 UUPM, hal ini tidak membuat sepenuhnya karakter produk hukum pertanahan kembali pada watak yang responsif, mengingat pada pelaksanaan PP No. 40 Tahun 1966 yang masih sering menuai konflik pertanahan terkait Hak Guna Usaha (HGU).

Kebijakan pemberian hak atas tanah oleh pemerintah kepada investor dalam UU No. 25 Tahun 2007 (UUPM) maupun PP No. 40 Tahun 1966 ternyata banyak menimbulkan dampak negatif, di antaranya adalah terjadinya kesenjangan dalam penguasaan dan pemanfaatan sumber daya alam berupa tanah di mana ada ketimpangan dalam distribusi penguasaan dan pemilikan tanah. Hal ini secara langsung berdampak terhadap kesejahteraan ekonomi rakyat khususnya kesejahteran Petani. Kebijakan tersebut dinilai tidak sejalan dengan amanah yang terkandung dalam Pasal 33 ayat (3) UUD 1945 dan pada akhirnya akan menampikkan keadilan bagi 
kemakmuran rakyat. Pentingnya memberikan keseimbangan antara ruang gerak bagi berkembangnya investasi sekaligus melindungi dan memberdayakan masyarakat dalam memenuhi kebutuhanya atas tanah. Politik hukum pertanahan "Prismatik" merupakan pilihan hukum yang tepat dalam mewujudkan tanah untuk kemakmuran rakyat dan kepemilikannya. 


\section{Daftar Pustaka}

\section{Buku}

Anisah, Siti dan Lucky Suryo Wicaksono. Hukum Investasi. Yogyakarta: FH UII Press, 2017

Arif, Sritua. Ekonomi Kerakyatan Indonesia: Mengenang Bung Hatta Bapak Ekonomi Kerakyatan Indonesia. Surakarta: Muhammadiyah University Press, 2002

Bernard L. Tanya, Politik Hukum Agenda Kepentingan Bersama, Yogyakarta: Genta Publishing, 2011

Bobo, Julius. Transformasi Ekonomi Rakyat. PT. Pustaka Cidesindo, 2003

Erwiningsih, Winahyu. Hak Menguasai Negara Atas Tanah. Yogyakarta: Total Media Press, 2009

Harsono, Boedi. Menuju Kesempurnaan Hukum Tanah Nasional. Jakarta: Universitas Trisakti, 2007

Hukum Agraria Indonesia. Jakarta: Djambatan, 2003

Hartono, Sunaryati. Politik Hukum Menuju Satu Sistem Hukum Nasional. Bandung; Alumni Press, 1991

Ilmar, Aminuddin. Hukum Penanaman Modal di Indonesia. Jakarta: Kencana, 2006

Ismail, Nurhasan. Perkembangan Hukum Pertanahan: Pendekatan Ekonomi Politik. Jakarta: HUMA dan Magister Hukum UGM, 2007

Mahfud MD, Moh. Politik Hukum di Indonesia. Jakarta: Penerbit PT. Raja Grafindo Persada, 2012 
Nonet, Philipe dan Philip Selzink. Law and Society in Transition Toward Responsive Law. New York: Harper and Row, 1978

Najih, M dan Soimin. Pengantar Hukum Indonesia Sejarah, Konsep Tata Hukum, dan Politik Hukum Indonesia. Malang: Setara Press, 2016

Parlindungan, A.P. Komentar Atas Undang-Undang Pokok Agraria. Bandung: Mandar Maju, 2008

Rajagukguk, Erman. Hukum Investasi Penanaman Modal Asing (PMA) dan Penanaman Modal Dalam Negeri (PMDN). Jakarta: Rajagrafindo Persada, 2019

Rahardjo, Satjipto, Ilmu Hukum, Cetakan Ketujuh, (Bandung: Titra Aditya Bhakti, 2012

Santoso, Urip. Hukum Agraria Kajian Komprehensif. Jakarta: Kencana, 2012

Umarhadi, Yoseph. Jebakan Liberalisasi: Pragmatisme, Dominasi Asing, dan Ketergantungan Ekonomi Indonesia. Yogyakarta: Cakrawala Institute, 2010

\section{Jurnal}

I Gede A.B Wiranto, “Urgensi dan Relevansi Pengaturan Tanah dalam Kegiatan Penanaman Modal Atau Investasi", Jurnal Hukum dan Dinamika Masyarakat, Edisi No.2 Vol.4, (2007)

Ni Ketut Sri Parwati dan Sudjito, "Politik Hukum Pemberian Hak Guna Usaha Setelah Berlakunya Undang-Undang Penanaman Modal Nomor 25 Tahun 2007 Dan Implikasinya Terhadap Nasib Petani", Mimbar Hukum, Edisi No. 1 Vol. 21, (2009) 
Nurhasan Ismail, "Arah Politik Hukum Pertanahan dan Perlindungan Kepemilikan Tanah Masyarakat", Jurnal Rechtsvinding, Edisi No. 1 Vol. 1 (2012)

Sri Hajati, Pengaturan Hak Atas Tanah dalam Kaitannya dengan Investasi. Desertasi Surabaya: Fakultas Hukum Universitas Airlangga, 2003

\section{Internet}

https://kpa.or.id/media/baca2/opini/8/Polemik_Pembangunan _Pabrik_Semen_Rembang_dan_Jerat_UU_P3H_untuk_Peta $\underline{\text { ni }}$

https://www.mongabay.co.id/2013/11/30/tolak-sawit-petani-ba nggai-ditangkapi/

https://tirto.id/warga-gugat-pt-mamuang-terkait-sengketa-lahanperkebunan-dcc 4

Putusan 21, 22 PUU-2007 Penanaman Modal, https://ditjenpp.kemenkumham.go.id

\section{Undang-Undang}

Undang-Undang Dasar Negara Republik Indonesia Tahun 1945

Undang-Undang No. 25 Tahun 2007 tentang Penanaman Modal

Undang-Undang No. 5 Tahun 1960 Tentang Peraturan Dasar Pokok Agraria

Peraturan Pemerintah No. 40 Tahun 1966 tentang Hak Guna Usaha, Hak Guna Bangunan dan Hak Pakai

Perpres No. 36 Tahun 2005 tentang Pengadaan Tanah Bagi Pelaksanaan Pembangunan Untuk Kepentingan Umum. 


\section{POLITIK HUKUM INVESTASI INDONESIA}

\section{Rivaldhy Harmi}

Praktisi Hukum Kantor Hukum Rivaldhy Harmi \& Rekan Jalan Cinta Damai No.02, Tanjungpinang Timur, Kepulauan Riau,

29125

Email: rivaldhyharmi@gmail.com

\section{A. Pendahuluan}

Globalisasi mempengaruhi banyak aspek dalam kehidupan negara-negara di dunia, salah satunya dalam aspek ekonomi. Globalisasi memberikan dampak terbukanya pasar antar negara di dunia. Masuknya aliran dana atau modal ke negara lain dalam bentuk investasi merupakan salah satu dari dampak tersebut. Indonesia sebagai negara yang terdampak oleh globalisasi tentunya harus melakukan pembangunan ekonomi demi mencapai tujuan negara, yakni memajukan kesejahteraan umum.

Tujuan negara tersebut terkandung dalam Undang-Undang Dasar Negara Republik Indonesia Tahun 1945. Merupakan amanat konstitusi yang mendasari pembentukan seluruh peraturan perundang-undangan, yang akan dibahas khususnya dalam bidang perekonomian. Konstitusi mengamanatkan agar pembangunan ekonomi nasional harus berdasarkan prinsip demokrasi yang mampu menciptakan terwujudnya kedaulatan ekonomi Indonesia.

Penanaman modal berperan penting untuk meningkatkan kesejahteraan rakyat dan mendatangkan banyak manfaat. Untuk itu, pemerintah perlu terus berupaya meningkatkan penanaman modal, yaitu dengan menciptakan iklim investasi yang kondusif. Hal ini yang menjadi latar 
belakang terbitnya Undang Undang tentang Penanaman Modal yang pertama di tahun 1967.

Alasan utama suatu Negara membutuhkan investor adalah untuk meningkatkan pertumbuhan ekonomi. Dengan meningkatnya pertumbuhan ekonomi, suatu negara dapat memberikan manfaat dan/atau keuntungan lainnya, diantaranya penyediaan lapangan pekerjaan, alih teknologi, mengembangkan industri substitusi impor untuk menghemat devisa, membangun sarana dan prasarana, serta mengembangkan daerah tertinggal.

Investor yang akan masuk ke suatu negara memiliki penilaian tersendiri yang menjadi pertimbangan mereka, apakah akan berinvestasi atau tidak di negara tersebut. Penilaian itu meliputi beberapa aspek, diantaranya: keuntungan ekonomi, kepastian hukum, dan stabilitas ekonomi. Tiga aspek tersebut yang menjadi aspek pokok pertimbangan bagi investor. Kemampuan suatu negara dalam memenuhi tiga persyaratan tersebut menjadi hal yang berharga dalam mendatangkan investor.

Untuk menarik modal asing dibutuhkan adanya keuntungan ekonomi bagi investor, seperti tersedianya bahan baku yang dekat dengan sumber daya alam, lokasi untuk mendirikan pabrik yang cukup, tenaga kerja yang murah dan pasar yang prospektif. Dengan melihat beberapa potensi yang dimiliki, Indonesia masih menjadi tempat tujuan penanaman modal yang menarik bagi investor asing meskipun dua aspek lainnya, stabilitas ekonomi dan kepastian hukum, masih dipertanyakan banyak pihak. ${ }^{277}$

Faktor lain yang menjadi syarat investasi asing adalah tersedianya lahan untuk mendirikan industri pendukung. Saat ini Indonesia masih kalah dengan China perihal penyediaan industri pendukung. Hal ini pun menjadi alasan yang kuat mengapa para investor lebih memilih China sebagai tempat

277 Erman Rajagukguk, Hukum Investasi di Indonesia: Anatomi Undang-Undang No. 25 Tahun 2007 Tentang Penanaman Modal, (Jakarta: Fakultas Hukum Unversitas Al-Azhar Indonesia, 2007), hlm. 27-28. 
berinvestasi. Beberapa hal yang dapat dilakukan untuk membangun industri pendukung, diantaranya: dengan menarik investor asing untuk membangun langsung industri pendukung; dan menumbuhkan industri lokal agar mampu mendirikan industri pendukung. ${ }^{278}$

Aspek kedua yakni, stabilitas politik (political stability). Investor tentu akan memilih meletakkan modalnya di suatu negara yang tingkat keamanan negaranya tinggi. Situasi negara yang carut-marut, dipenuhi oleh konflik politik, tentu akan menjadi negara yang sangat tidak menarik bagi para investor. Investor akan datang ke suatu negara untuk mengembangkan usahanya jika negara yang bersangkutan terbangun proses stabilitas politik yang baik.

Pertikaian antar elite politik menjadi salah satu pemicu instabilitas yang mengakibatkan mengganjalnya recovery ekonomi di Indonesia. Konflik politik sangat berpengaruh terhadap dunia usaha Indonesia. Dengan country risk yang sangat tinggi di Indonesia maka banyak investor yang enggan datang ke Indonesia. Faktor lain yang menjadi penghambat, kegagalan mengatasi korupsi yang mewabah serta memperbaiki transparansi dan efisiensi. ${ }^{279}$

Aspek atau syarat yang terakhir dalam mendatangkan investasi adalah adanya jaminan kepastian hukum (Legal Certainty). Perlunya suatu tatanan hukum yang memiliki nilai kebenaran dan keadilan serta tidak bersifat diskriminatif. Kepastian hukum ini harus ada dari level tertinggi hingga level terendah sampai dengan level penyelesaian apabila ada sengketa atau permasalahan. Artinya kepastian hukum itu harus ada pada tingkat Undang-Undang, Peraturan Daerah, hingga Keputusan Pengadilan. Untuk menjamin adanya konsistensi dalam pelaksanaan peraturan diperlukan adanya dukungan aparatur hukum yang profesional dan bermoral serta didukung oleh adanya budaya hukum

$\begin{array}{ll}278 & \text { Ibid., hlm. } 30 . \\ 279 & \text { Ibid., hlm. } 33 .\end{array}$


masyarakat. ${ }^{280}$ Sehubungan dengan hal tersebut, maka permasalahan yang menjadi fokus kajian dalam penelitian ini adalah bagaimanakah politik hukum investasi di Indonesia

\section{B. Sejarah Hukum Investasi di Indonesia}

Investasi dipandang sebagai sebuah kegiatan penanaman modal asing tentunya sudah ada dari jaman penjajahan Belanda atau bahkan mungkin sebelumnya. Berbeda halnya ketika berbicara tentang sejarah hukum investasi, hukum investasi dimaknai sebagai sebuah aturan yang dibuat untuk mengatur kegiatan penanaman modal.

Dalam rangka mengundang investasi asing, diperlukan suatu aturan yang jelas dan pasti, sehingga para investor akan merasa aman dan terhindar dari keragu-raguan dalam menanamkan modal. Maka pada tahun 1958 diterbitkanlah Undang-Undang Nomor 78 Tahun 1958 tentang Penanaman Modal Asing dengan harapan dapat memperbesar produksi nasional, yang bertujuan untuk mempercepat pembangunan ekonomi Indonesia sehingga dapat meningkatkan kesejahteraan rakyat Indonesia.

Namun, Pemerintahan Soekarno mengganggap bahwa dengan mengikis habis penanaman modal asing di Indonesia, dapat memperbesar produksi nasional dalam negeri sehingga dapat meningkatkan taraf hidup rakyat Indonesia. Hal tersebut mendasari dicabutnya Undang-Undang Nomor 78 Tahun 1958 tentang Penanaman Modal Asing dengan diterbitkannya Undang-Undang yang baru, yakni Undang-undang Nomor 16 Tahun 1965 tentang Pencabutan Undang-Undang Nomor 78 Tahun 1958 Tentang Penanaman Modal Asing, yang telah diubah dan ditambah dengan Peraturan Pemerintah Pengganti Undang-Undang Nomor 15 Tahun 1960.

Selanjutnya, untuk mewujudkan cita-cita dan tujuan bangsa Indonesia harus dicapai secara menyeluruh. Cita-cita pembangunan nasional tidak hanya dilakukan secara fisik 
namun juga non fisik. ${ }^{281}$ Untuk melaksanakan pembangunan tersebut tentunya dibutuhkan dana yang tidak sedikit sehingga negara perlu mengundang investor asing untuk masuk ke Indonesia. Maka pada tahun 1966 diterbitkanlah Ketetapan MPRS No. XXIII Tahun 1966 tentang Pembaharuan Kebijaksanaan Landasan Ekonomi Keuangan dan Pembangunan sebagai landasan hukum secara formal untuk mengatur masalah investasi asing.

Berbeda dengan pemerintahan orde lama, pemerintahan orde baru mengambil beberapa langkah strategis untuk mengubah sistem ekonomi Indonesia yang dari sistem ekonomi komando kepada sistem ekonomi pasar. Sebagai tindak lanjut dari diterbitkannya TAP MPRS No. XXIII Tahun 1966 tentang pembaruan Landasan Kebijakan Ekonomi Keuangan dan Pembangunan yang bertujuan untuk mendorong swasta masuk ke sektor-sektor strategis serta mendorong pertumbuhan ekonomi Indonesia selama pemerintahan orde baru yaitu dengan diterbitkannya Undang Undang Nomor 1 Tahun 1967 tentang Penanaman Modal Asing dan Undang Undang Nomor 6 Tahun 1968 tentang Penanaman Modal Dalam Negeri.

Perlunya pengaturan pemerintah terhadap penanaman modal asing dimaksudkan untuk memberikan arah terhadap penanaman modal asing yang dilaksanakan di Indonesia agar dapat berperan dalam pembangunan nasional. Dengan kata lain, kebijakan penanaman modal asing di Indonesia, ditetapkan berdasarkan pemikiran bahwa penanaman modal asing harus dapat memberikan kontribusi untuk memperkuat dan memperkokoh struktur pembangunan nasional. Maka dengan adanya berbagai pengaturan terhadap penanaman modal asing tidak lain dimaksudkan untuk lebih memberi peluang yang lebih luas kepada para penanam modal asing

281 Sentosa Sembiring, Hukum Investasi: Pembahasan Dilengkapi dengan Undang-Undang Nomor 25 Thun 2007 tentang Penanaman Modal, (Bandung: CV. Nuansa Aulia, 2007), hlm. 122. 
dalam melaksanakan kegiatannya melalui dukungan iklim penanaman modal asing yang kondusif. 282

Pada tahun 1994 pemerintah melalukan suatu terobosan dengan tujuan mengundang lebih banyak investor asing untuk datang. Pemerintah mengeluarkan Peraturan Pemerintah Nomor 20 Tahun 1994 tentang Kepemilikan Saham Dalam Perusahaan yang Didirikan Dalam Rangka Penanaman Modal Asing. Pertimbangan dikeluarkannya Peraturan Pemerintah ini adalah bahwa dalam rangka lebih mempercepat peningkatan dan perluasan kegiatan ekonomi dan pembangunan nasional pada umumnya, diperlukan langkah-langkah untuk lebih mengembangkan iklim usaha yang semakin mantap dan lebih menjamin kelangsungan penanaman modal asing. ${ }^{283}$

Di akhir era orde baru terjadi suatu peristiwa penting internasional yang sangat mempengaruhi tatanan hukum investasi nasional Indonesia. Seperti yang diketahui pada era orde baru terdapat dua undang undang yang membedakan penanaman modal yang dilakukan oleh asing dan oleh pemodal dalam negeri. Dengan adanya dua kebijakan yang mengatur tentang penanaman modal ini, memberikan gambaran adanya pemisahaan antara penanaman modal asing dan penanaman modal dalam negeri. Pemisahan pengaturan penanaman modal ini bertolak belakang dengan prinsip perdagangan internasional.

Seiring perkembangan jaman, lahirnya World Trade Organization (WTO), sebuah organisasi internasional yang akan menjadi tempat bernaungnya negara-negara dalam berdagang secara internasional, politik hukum investasi Indonesia harus menyesuaikan diri. Sebagai langkah awal penyesuaian ini, pemerintah menerbitkan Undang Undang Nomor 7 Tahun 1994 tentang Pengesahan Agreement Establishing The World Trade Organization (Persetujuan Pembentukan Organisasi Perdagangan Dunia).

282 Aminuddin Ilmar. Hukum Penanaman Modal di Indonesia. (Jakarta: Prenada Media, 2004), hlm. 37.

283 Sembiring, Op.Cit., hlm. 140. 
Dengan bergabungnya Indonesia di WTO tentunya Indonesia harus berusaha menegakkan prinsip-prinsip pokok yang dikandung dalam General Agreement on Tariff and Trade/GATT 1947 (Persetujuan Umum mengenai Tarif dan Perdagangan Tahun 1947), berikut persetujuan susulan yang telah dihasilkan sebelum perundingan Putaran Uruguay. Termasuk didalamnya yang membahas mengenai Trade Related Investment Measures/TRIMs (Ketentuan Investasi yang berkaitan dengan Perdagangan), yang bertujuan untuk mengurangi atau menghapus segala kebijakan di bidang investasi yang dapat menghambat kegiatan perdagangan.

Seiring dengan perubahan perekonomian global dan keikutsertaan Indonesia dalam berbagai kerja sama internasional perlu diciptakan iklim penanaman modal yang kondusif, promotif, memberikan kepastian hukum, keadilan, dan efisien dengan tetap memperhatikan kepentingan ekonomi nasional, Undang-Undang Nomor 1 Tahun 1967 tentang Penanaman Modal Asing dan Undang-Undang Nomor 6 Tahun 1968 tentang Penanaman Modal Dalam Negeri telah diganti karena tidak sesuai lagi dengan kebutuhan percepatan perkembangan perekonomian dan pembangunan hukum nasional, khususnya di bidang penanaman modal. Kesan diskriminatif yang dilakukan kepada investor asing dengen investor dalam negeri membuat kedua Undang-Undang tersebut sudah tidak relevan lagi. Pemerintah Indonesia membentuk aturan penanaman modal yang tidak memisahkan antara penanaman modal asing dan penanaman modal dalam negeri, yaitu Undang-Undang Nomor 25 Tahun 2007 tentang Penanaman Modal.

\section{Regulasi tentang Penanaman Modal}

Selain diatur dalam Undang-Undang Nomor 25 Tahun 2007, regulasi tentang penanaman modal dapat ditemukan dalam berbagai peraturan perundang-undangan, antara lain:284

284 Siti Anisah, Lucky Suryo Wicaksono, Hukum Investasi, (Yogyakarta: FH UII Press, 2007), hlm. 11-12. 
1. Peraturan Pemerintah Nomor 45 Tahun 2008 tentang Pedoman Pemberian Insentif dan Pemberian Kemudahan Penanaman Modal di Daerah;

2. Peraturan Presiden Nomor 76 Tahun 2007 tentang Kriteria dan Persyaratan Bidang Usaha yang Tertutup dan Terbuka dengan Persyaratan bagi Penanaman Modal;

3. Peraturan Presiden Nomor 27 Tahun 2009 tentang Pelayanan Terpadu Satu Pintu di Bidang Penanaman Modal;

4. Peraturan Presiden Nomor 16 Tahun 2012 tentang Rencana Umum Penanaman Modal;

5. Peraturan Presiden Nomor 44 Tahun 2016 tentang Daftar Bidang Usaha yang Tertutup dan Terbuka dengan Persyara tan bagi Penanaman Modal;

6. Peraturan Kepala Badan Koordinasi Penanaman Modal Nomor 6 Tahun 2011 tentang Tata cara Pelaksanaan, Pembinaan, dan Pelaporan Pelayanan Terpadu Satu Pintu di Bidang Penanaman Modal;

7. Peraturan Kepala Badan Koordinasi Penanaman Modal Nomor 14 Tahun 2015 tentang Pedoman dan Tata Cara Izin Prinsip Penanaman Modal;

8. Peraturan Kepala Badan Koordinasi Penanaman Modal Nomor 15 Tahun 2015 tentang Pedoman dan Tam Cara Perizinan dan Non-perizinan Penanaman Modal;

9. Peraturan Kepala Badan Koordinasi Penanaman Modal Nomor 16 Tahun 2015 tentang Pedoman dan Tata Cara Pelayanan Fasilitas Penanaman Modal;

10. Peraturan Kepala Badan Koordinasi Penanaman Modal Nomor 17 Tahun 2015 tentang Pedoman dan Tata Cara Pengendalian Pelaksanaan Penanaman Modal;

11. Peraturan Kepala Badan Koordinasi Penanaman Modal Nomor 6 Tahun 2016 tentang Perubahan atas Peraturan Kepala BKPM Nomor 14 Tahun 2015 tentang Pedoman dan Tata Cara Izin Prinsip Penanaman Modal.

Selain itu, terdapat Bilateral, Regional, dan Multilateral Investment Treatis yang telah diratifikasi oleh Pemerintah 
Indonesia. Hal tersebut menjadi penting dikarenakan Indonesia juga mengenal penanaman modal asing. Untuk itu, dalam aspek internasional juga perlu diperhatikan kesepakatan-kesepakatan khususnya yang telah diratifikasi atau ditandatangani baik Bilateral, Regional, dan Multilateral Investment Treatis yang terkait dengan penanaman modal. Treatis atau perjanjian dimaksud yang perlu diperhatikan antara lain :285

1. Undang-Undang Nomor 32 Tahun 1968 tentang Persetujuan atas Konvensi tentang Penyelesaian Perselisihan antara Negara dan Warga Negara Asing mengenai Penanaman Modal (Convention on the Settlement of Investment Disputes between States and Nationals of Other States) atau dikenal dengan ICSID;

2. Undang-Undang Nomor 7 Tahun 1994 tentang Pengesahan Agreement Establishing the World Trade Organization yang didalanmya juga mencakup kesepakatan-kesepakatan mengenai Trade Related Aspects of Intellectual Property Rights (TRIPS), Trade Related Aspects of Investment Measures (TRIMS) dan General Agreement on Trade in Services (GATS):

3. Keputusan Presiden Nomor 34 Tahun 1981 tentang Pengesahan Convention on the Recognition and Enforcement of Foreign Arbitral Awards;

4. Keputusan Presiden Nomor 31 Tahun 1986 tentang Pengesahan Convention Establishing the Multilateral Investment Guarantee Agency atau dikenal dengan MIGA;

5. Perjanjian-perjanjian internasional yang berhubungan dengan kerja sama investasi dan perdagangan internasional lainnya yang bersifat bilateral (Bilateral Investment Treaty atau BITS), maupun multilateral (misalnya ASEAN Free Trade Agreement, Asia-Pasific Economic Cooperation, dan ASEAN-China Free Trade Agreement).

Pengaturan penanaman modal di Indonesia berkembang sangat dinamis sejak diberlakukannya otonomi daerah. 
Pembagian urusan kewenangan pemerintah di bidang penanaman modal yang semula ada di Pemerintah Pusat sebagian dialihkan kepada Pemerintah Daerah baik itu pemerintah daerah provinsi, pemerintah daerah kabupaten atau kota. Peraturan yang berkaitan dengan investasi oleh pemerintah (pusat dan daerah) antara lain:286

1. Undang-Undang atau Peraturan Daerah yang mengatur tentang Anggaran dan Pendapatan Belanja Negara atau Daerah;

2. Undang-Undang Nomor 17 Tahun 2003 tentang Keuangan Negara;

3. Undang-Undang Nomor 1 Tahun 2004 tentang Pembendaharaan Negara;

4. Undang-Undang Nomor 2 Tahun 2015 tentang Penetapan Peraturan Pemerintah Pengganti Undang-Undang Nomor 2 Tahun 2014 tentang Perubahan atas Undang-Undang Nomor 23 Tahun 2014 tentang Pemerintahan Daerah Menjadi Undang-Undang;

5. Peraturan Pemerintah Nomor 5 Tahun 2005 tentang Pengelolaan Keuangan Daerah;

6. Peraturan Pemerintah Nomor 44 Tahun 2005 tentang Tata Cara Penyertaan dan Penatausahaan Modal Negara pada Badan Usaha Milik Negara dan Perseroan Terbatas;

7. Peraturan Pemerintah Nomor 6 Tahun 2006 tentang Pengelolaan Barang Milik Negara atau Daerah;

8. Peraturan Pemerintah Nomor 49 Tahun 2011 tentang Perubahan Atas Peraturan Pemerintah No. 1 Tahun 2008 tentang Investasi Pemerintah;

9. Peraturan Menteri Dalam Negeri Nomor 52 Tahun 2012 tentang Pedoman Pengelolaan Investasi Pemerintah Daerah.

\section{Hukum Investasi dalam Kaitannya dengan Perdagangan Internasional}

Isu globalisasi ekonomi semakin marak setelah disetujui dan ditandatanganinya kesepakatan GATT-Puturan Uruguay 
oleh 122 Negara anggota di Marrakesh, Maroko pada tanggal 15 April 1994 (Marrakesh Meeting). Pada pertemuan perundingan tersebut disetujui perubahan nama GATT menjadi WTO.

GATT merupakan suatu kesepakatan perdagangan multilateral yang berlaku sejak tahun 1948 dengan tujuan utama yang diantaranya memuat beberapa hal mengenai liberalisasi perdagangan yang bertujuan untuk meningkatkan jumlah perdagangan dunia sehingga meningkatkan produksi, dan memperjuangkan penurunan tarif dan penghapusan hambatan-hambatan perdagangan seperti hambatan tarif bea masuk (tariff barrier) dan/atau hambatan lainnya (non tariff barrier), ${ }^{287}$ serta mengatur perdagangan yang mencakup tentang hak kekayaan intelektual (intellectual property rights) dan penanaman modal/investasi yang berkaitan dengan Perdagangan (investment measures). ${ }^{288}$

Selama pertemuan perundingan pada Putaran Uruguay berlangsung, terdapat 15 hal yang menjadi topik dalam agenda perundingan, di antara agenda perundingan tersebut membahas mengenai beberapa hal-hal yang dirundingkan, salah satu di antaranya adalah perundingan di bidang aspek-aspek dagang yang terkait dengan ketentuan investasi yang berkaitan dengan perdagangan (Investment Measure).

Pada perundingan Putaran Uruguay tersebut kemudian disepakati perjanjian mengenai aspek-aspek dagang yang terkait dengan ketentuan investasi yang berkaitan dengan perdagangan atau lebih dikenal dengan sebutan TRIMs yang merupakan salah satu dari perjanjian utama WTO dan bertujuan untuk mengurangi atau menghapus segala kebijakan di bidang investasi yang dapat menghambat kegiatan perdagangan

Pada aspek-aspek dagang yang terkait dengan ketentuan investasi yang berkaitan dengan perdagangan memuat

${ }^{287}$ https:/ / republika.co.id/berita/kolom/wacana/18/06/18/paiqqw385-pe rang-dagang-ascina-dan-runtuhnya-masa-depan-wto Akses 14 Juli 2018.

288 Syahmin AK, Hukum Dagang Internasional dalam Kerangka Studi Analitik, (Jakarta: Raja Grafindo Persada, 2007), 35. 
beberapa prinsip di antaranya adalah prinsip non diskriminasi (Principle of Non-Discrimination) yang mensyaratkan kewajiban pada suatu negara penerima invetasi (host country) untuk tidak melakukan diskriminasi atau perbedaan dalam memberikan perlakuan terhadap negara lain yang menanamkan modal di negaranya (most favoured nation) dan keharusan memberikan perlakuan yang sama oleh negara penerima investasi terhadap investor asing dan investor dalam negeri (National Treatment). ${ }^{289}$

Indonesia menganggap WTO sebagai wadah yang tepat untuk meningkatkan perekonomian negara, terutama dalam menjalankan hubungan perdagangan internasional yang baik dan menguntungkan. Dalam hubungan perdagangan internasional, keberhasilan Indonesia dalam meningkatkan pembangunan nasional juga akan bergantung pada perkembangan tatanan ekonomi dunia serta kemantapan sistem perdagangan internasional di samping kemampuan penyesuaian ekonomi nasional terhadap perkembangan yang ada. Salah satu faktor yang sangat mempengaruhi perekonomian dunia, adalah tatanan atau sistem yang merupakan dasar dalam hubungan perdagangan antar negara. Tatanan atau sistem yang dimaksud adalah GATT.

Persetujuan tersebut terwujud pada tahun 1947, dan Indonesia telah ikut serta dalam persetujuan tersebut sejak tanggal 24 Februari 1950. Manfaat dari keikutsertaan Indonesia dalam persetujuan tersebut pada dasarnya bukan saja memungkinkan terbukanya peluang pasar internasional yang lebih luas, tetapi juga menyediakan kerangka perlindungan multilateral yang lebih baik bagi kepentingan nasional dalam perdagangan internasional, khususnya dalam menghadapi mitra dagang dalam hubungan perdagangan internasional.

Indonesia sebagai negara anggota WTO telah meratifikasi kesepakatan pendirian WTO berdasarkan Undang-Undang Nomor 7 Tahun 1994 tentang Pengesahan Persetujuan Pembentukan Organisasi Perdagangan Dunia pada tanggal 02 November 1994. Sebagai konsekuensinya Indonesia

289 Siti Anisah, Lucky Suryo Wicaksono, Op.Cit., 270. 
berkewajiban untuk menyempurnakan atau mempersiapkan peraturan perundangan yang diperlukan. Khusus untuk kebijakan penanaman modal, maka Indonesia dalam menetapkan kebijakannya harus disesuaikan dengan aturan-aturan dalam TRIMs, atau aspek-aspek dagang yang terkait dengan ketentuan investasi yang berkaitan dengan perdagangan.

Indonesia dalam meratifikasi TRIMs berdasarkan Lampiran 1A ayat (7) Undang Undang Nomor 7 Tahun 1994 Tentang Persetujuan Pembentukan Organisasi Perdagangan Dunia. Karena suatu Perjanjian Perdagangan Internasional mengikat berdasarkan kesepakatan para pihak yang membuatnya, ketika suatu negara telah meratifikasinya, maka negara tersebut berkewajiban untuk mengundangkannya kedalam aturan hukum nasionalnya. ${ }^{290}$

Di Indonesia, Penanaman Modal diatur dalam Undang-Undang Penanaman Modal Nomor 25 Tahun 2007 tentang Penanaman Modal, sebagai pengganti Undang-undang Nomor 6 Tahun 1968 tentang Penanaman Modal Dalam Negeri dan Undang-undang Nomor 1 Tahun 1967 tentang Penanaman Modal Asing.

\section{E. Arah dan Kebijakan Hukum Investasi Indonesia Pasca Trade Related Investment Measures}

Kebijakan investasi Pemerintah Indonesia sebelum meratifikasi kesepakatan pendirian WTO berdasarkan Undang Undang Nomor 7 Tahun 1994 tentang Pengesahan Persetujuan Pembentukan Organisasi Perdagangan Dunia adalah kebijakan investasi berdasarkan Undang Undang Nomor 1 Tahun 1967 tentang Penanaman Modal Asing sebagaimana telah diubah dengan Undang-Undang Nomor 11 Tahun 1970 tentang Perubahan dan Tambahan Undang Undang Nomor 1 Tahun 1967 tentang Penanaman Modal Asing, dan Undang Undang Nomor 6 Tahun 1968 tentang Penanaman Modal Dalam Negeri

290 Huala Adolf, Hukum Perdagangan Internasional, (Jakarta: Raja Grafindo Persada, 2004), hlm. 78. 
sebagaimana telah diubah dengan Undang Undang Nomor 12 Tahun 1970 tentang Perubahan dan Tambahan Undang Undang Nomor 6 Tahun 1968 tentang Penanaman Modal Dalam Negeri.

Sebagai implikasi dari diratifikasinya kesepakatan pendirian WTO berdasarkan Undang Undang Nomor 7 Tahun 1994 tentang Pengesahan Persetujuan Pembentukan Organisasi Perdagangan Dunia, khusus untuk kebijakan penanaman modal, Indonesia berkewajiban untuk menyempurnakan dan/atau mempersiapkan serta menerapkan ketentuan-ketentuan yang disepakati berdasarkan Persetujuan tentang Kebijakan Investasi yang berkaitan dengan Perdagangan (TRIMs) berdasarkan Lampiran 1A ayat (7) Undang Undang Nomor 7 Tahun 1994 tentang Pengesahan Persetujuan Pembentukan Organisasi Perdagangan Dunia dalam peraturan perundang-undangan yang berlaku dengan tetap memperhatikan hukum nasional dan/atau hukum internasional yang berlaku, maka pada 26 April 2007 di era Pemerintahan Presiden Susilo Bambang Yudhoyono yang sangat pro-neoliberal, dibentuk dan diundangkanlah Undang Undang Nomor 25 Tahun 2007 tentang Penanaman Modal. Kesesuaian antara Undang Undang Nomor 25 Tahun 2007 tentang Penanaman Modal dengan Kebijakan Investasi yang berkaitan dengan Perdagangan (TRIMs) merupakan suatu kewajiban yang harus dipatuhi oleh Pemerintah Indonesia.

Pada Undang Undang Nomor 25 Tahun 2007 tentang Penanaman Modal ini, modal asing tidak lagi dibatasi, bisa mencapai 100\%. Hak Guna Usaha bisa 94 tahun dan jika waktunya sudah habis, bisa diperpanjang 35 tahun lagi. Lebih tragis lagi tidak ada lagi perlakuan berbeda antara modal asing dan domestik. Akibatnya, sebagian besar sumber daya alam dan sektor ekonomi strategis dikuasai asing. Akhirnya, seperti diperingatkan Bung Karno, sebagian besar keuntungan mengalir keluar, sedangkan rakyat ditinggal kering-kerontang. Konon, rakyat Indonesia hanya menikmati $10 \%$ dari 
keuntungan ekonomi, sedangkan $90 \%$ nya dibawa oleh pihak asing keluar. ${ }^{291}$

Kehadiran Undang Undang Nomor 25 Tahun 2007 tentang Penanaman Modal di Indonesia disambut dengan perbedaan pandangan yang sangat tajam. Sebagian mengatakan bahwa Undang-Undang Nomor 25 Tahun 2007 tentang Penanaman Modal ini terlalu liberal, berbeda dengan landasan filosofis dan konstitusional ekonomi Indonesia yang ditetapkan dalam UUD NRI Tahun 1945 sehingga dirasa kurang tepat untuk meningkatkan iklim investasi. Hal ini dikarenakan penurunan iklim investasi yang disebabkan tingginya biaya berbisnis (pungli, perizinan pusat dan perda serta kenaikan tarif BBM dan listrik) yang mengakibatkan menurunnya pasar Indonesia karena menurunnya daya beli. ${ }^{292}$

Beberapa pihak menolak disebut sebagai penganut ekonomi neoliberalisme, namun kenyataannya neoliberalisme telah merasuk hampir di seluruh kegiatan ekonomi di Indonesia. "Bohong kalau ada yang bilang Indonesia atau seseorang bebas dari neoliberal. Praktik ekonomi neoliberal telah digunakan dalam seluruh praktik investasi, perdagangan, dan keuangan di negara ini," ujar Indah Suksmaningsih, Direktur Eksekutiftif Institute Global for Justice (IGJ), dalam konferensi Pers Pernyataan Sikap IGJ di Jakarta, Selasa (9/8). Untuk memperkuat argumennya, Indah memberikan beberapa contoh, pertama di bidang investasi, puncak penerapan aturan yang berwatak neoliberalisme adalah dalam undang-undang investasi, yaitu dikeluarkannya Undang Undang Nomor 25 Tahun 2007 tentang Penanaman Modal. Undang-Undang semasa Presiden Susilo Bambang Yudhono ini memberikan fasilitas, intensif, dan kemudahan yang sangat luas kepada penanam modal. "Penguasa tanah diperbolehkan hingga 95

291 http://www.berdikarionline.com/legalisasi-neokolonialisme/ Akses 14 Juli 2018.

http:// www.hukumonline.com/berita/baca/hol15450/penerapan-liberalisas i-dalam-ruu-pm-tidak-tepat Akses 14 Juli 2018. 
tahun, zaman Hindia Belanda saja batasnya cuma sampai 75 tahun," terangnya. ${ }^{293}$

Paham ekonomi neoliberal, merujuk pada sistem perekonomian yang menjadikan pasar sebagai panglima dengan peran negara seminimal mungkin. Paham itu sesuai rekomendasi Konsensus Washington yang antara lain mensyaratkan liberalisasi perdagangan melalui kesepakatan dalam WTO dan berbagai perjanjian dengan lembaga keuangan multilateral sebagai prasyarat pemberian utang. ${ }^{294}$

Perlakuan sama antara penanaman modal asing dan penanamana modal dalam negeri sebagai prinsip dasar penyusunan kebijakan penanaman modal dipandang sebagai tindakan yang gegabah dan tidak berpihak pada kepentingan rakyat banyak. Indonesia sebagai negara yang merdeka dan berdaulat, secara politik memiliki hak untuk mengatur sistem ekonominya dengan mengutamakan kepentingan negara dan rakyatnya bukan justru mendahulukan kepentingan asing. Sedangkan dari pihak pemerintah memiliki alasan mengapa dirasakan perlu ada liberalisasai dalam penanaman modal, hal ini dikarenakan pemerintah optimis investasi usaha di berbagai bidang akan semakin meningkat. Investasi adalah instrumen yang penting dalam pembangunan nasional. Diperlukan undang-undang yang benar-benar berbeda dan menarik bagi penanaman modal asing maupun penanaman modal dalam negeri.

Terlepas dari perbedaan pandangan tersebut, Indonesia sebagai negara anggota organisasi perdagangan dunia memiliki kewajiban internasional yang telah disepakatinya. Tidak terkecuali Undang-Undang Nomor 25 Tahun 2007 tentang Penanaman Modal harus pula harmonis dengan kesepakatan-kesepakatan internasional yang diterima Indonesia pada berbagai kerjasama internasional. Jika hal ini

293 https://nasional.kompas.com/read/2009/06/09/13313833/Kebijakan.E konomi.Indonesia.100.Persen.Liberal Akses 14 Juli 2018.

294

https://edukasi.kompas.com/read/2009/06/12/05541479/.neoliberalisme Akses 14 Juli 2018. 
tidak dipenuhi, maka Indonesia akan dibawa kedalam penyelesaian sengketa oleh negara-negara lain yang bersangkutan.

\section{F. Kepentingan Nasional dan Persoalan Politik Hukum dalam Undang-Undang Nomor 25 Tahun 2007 Tentang Penanaman Modal}

Tujuan pembentukan Undang-Undang Nomor 25 Tahun 2007 tentang Penanaman Modal adalah untuk mengatur pelaksanaan penanaman modal di Indonesia, baik bagi penanam modal dalam negeri maupun asing. Manfaat adanya penanaman modal atau investasi ini untuk meningkatkan pertumbuhan ekonomi (economic growth). Apabila pertumbuhan ekonomi meningkat tentunya akan memberikan pengaruh bagi banyak aspek, diantaranya:

1. Menciptakan lapangan pekerjaan

2. Meningkatkan pembangunan ekonomi berkelanjutan

3. Meningkatkan kemampuan daya saing usaha nasional

4. Meningkatkan kapasitas dan kemampuan teknologi nasional

5. Mendorong pengembangan ekonomi kerakyatan

6. Mengolah ekonomi potensial untuk menjadi kekuatan ekonomi riil dengan menggunakan dana yang berasal dari dalam negeri maupun luar negeri.

7. Meningkatkan kesejahteraan masyarakat.

Dalam pelaksanaan investasi tentu akan ditemui hambatan-hambatan dalam pelaksanaannya. Permasalahan ini telah menjadi hambatan dan membuat Indonesia kalah bersaing dibandingkan dengan negara lain. Investor sangat berharap adanya perubahan serta percepatan ke arah yang lebih baik dari iklim penanaman modal di Indonesia. Hambatan-hambatan tersebut, diantaraya:

1. Pembenahan Kebijakan, dan Implementasi Investasi

Hal yang terjadi bahwa tidak adanya konsistensi dalam kebijakan, pengaturan dan implementasi Investasi. 
Inkonsistensi dapat dilihat dari tugas dan fungsi pokok Badan Koordinasi Penanaman Modal, apakah sebagai "one stop services center" atau sebagai badan promosi investasi. Hal ini dapat membingungkan investor/calon investor.

2. Masalah dan hambatan birokrasi

Sudah bukan rahasia umum rentang birokrasi di daerah yang terlalu panjang, ini telah mengakibatkan biaya yang mahal serta terbuka peluang korupsi atau pungutan liar yang dapat mengakibatkan buruknya iklim investasi di Indonesia.

3. Ketidakpastian dalam interpretasi dan implementasi otonomi daerah.

Dengan banyaknya permasalahan terkait perda dibidang investasi menunjukkan bahwa pemahaman terhadap otonomi daerah masih keliru. Permasalahan dimaksud banyak terkait dengan masalah pajak dan retribusi daerah yang mengakibatkan kegiatan investasi menjadi unpredictable. Jika permasalahan ini terus berlanjut, maka daya saing investasi akan selalu menurun karena rendahnya minat investor untuk berinvestasi di daerah.

4. Sumber daya manusia dan permasalahan kebijakaan ketenagakerjaan

Penerapan kebijakan di bidang ketenagakerjaan yang tidak transparan telah mengakibatkan kondisi ketenagakerjaan menjadi kurang produktif, tenaga kerja yang tidak terampil, etos kerja yang lemah, kenaikan upah minimum yang terlalu cepat, dan maraknya demo dan pemogokan serta kasus-kasus perburuhan yang membuat investor melakukan relokasi usahanya ke beberapa negara tetangga yang lebih kondusif. Tingkat pendidikan dan rendahnya kompetensi yang dimiliki sumber daya manusia telah menjadi salah satu pertimbangan investor untuk berinvestasi di daerah. 
5. Tingkat korupsi yang masih tinggi

Pelaksanaan otonomi daerah yang masih menunjukkan berbagai kelemahan bahkan makin merebakkan praktek korupsi dan pungutan liar ke daerah-daerah. Dalam praktek dilapangan banyak yang menggunakan instrumen regulasi sebagai justifikasinya.

6. Kurangnya insentif bidang pajak maupun non pajak

Dalam implementasinya di daerah, skema insentif yang diatur dalam berbagai aturan ternyata tidak dilaksanakan sebagaimana mestinya, sehingga kebijakan investasi yang di tetapkan oleh pemerintah tidak sepenuhnya dapat dirasakan manfaatnya oleh investor.

7. Rendahnya jaminan dan perlindungan investasi

Meskipun Undang-Undang Penanaman modal telah mengatur jaminan dan perlindungan terhadap kegiatan investasi dan pemerintah secara aktif menyepakati berbagai perjanjian bilateral mengenai promosi dan perlindungan investasi, namun dalam prakteknya kurang terlihat komitmen yang sungguh-sungguh dalam perlindungan investasi.

8. Lemahnya penegakan dan kepastian hukum

Munculnya berbagai kasus seperti : kasus cemex, divestasi KPC, Karaha Bodas, Mining Churcil, dan lainnya menunjukkan bahwa penegakan hukum khususnya hukum kontrak masih lemah. Hal ini mengakibatkan ketidakpastian hukum dan pada akhirnya mengurangi daya saing Indonesia sebagai negara tujuan investasi.

9. Lemahnya koordinasi antar kelembagaan

Ketidakjelasan tupoksi dari lembaga pemerintahan telah menimbulkan koordinasi yang tidak harmonis dalam konteks kegiatan investasi. Terlebih kondisi di daerah kerap terjadi saling lempar tanggung jawab antar dinas. Kordinasi 
yang kurang terjadi oleh adanya pertimbangan subyektif yang berlatar belakang kepentingan suatu kelompok (politis) maupun ekonomi.

10. Permasalahan lain

Permasalahan lain yang membutuhkan perhatian serta pembenahan adalah: masalah stabilitas politik dan keamanan yang relatif rentan terjadi seperti di Aceh dan Papua. Hal ini sangat berpengaruh pada arus investasi yang akan ke daerah tersebut.

\section{G. Penutup}

Tiga faktor penting dalam pertimbangan penanam modal untuk melakukan investasi atau tidak di suatu negara adalah keuntungan ekonomi (economic opportunity), stabilitas politik (political stability), dan kepastian hukum (legal certainty). Unsur kepastian hukum inilah yang ingin perintah Indonesia penuhi dengan diterbitkannya Undang-Undang Nomor 25 Tahun 2007 tentang Penanaman Modal. Demi memberikan kepastian hukum untuk meyakinkan para investor untuk meletakkan dana atau modalnya di Indonesia.

Bergabungnya Indonesia dalam organisasi perdagangan dunia yakni World Trade Organization sangat memengaruhi corak dan arah kebijakan politik hukum dalam pembentukan aturan mengenai investasi di Indonesia, terutama dalam Undang-Undang Nomor 25 Tahun 2007 tentang Penanaman Modal. Arah kebijakan yang neoliberal, dimana pasar di Indonesia dibuka lebar melalui investasi namun tetap diatur oleh pemerintah dalam pelaksanaannya. 


\section{Daftar Pustaka}

\section{Buku}

Adolf, Huala. Hukum Perdagangan Internasional. Jakarta: Raja Grafindo Persada, 2004.

AK, Syahmin. Hukum Dagang Internasional dalam Kerangka Studi Analitik. Jakarta: Raja Grafindo Persada, 2007.

Ilmar, Aminuddin. Hukum Penanaman Modal di Indonesia. Jakarta: Prenada Media, 2004.

Rajagukguk, Erman. Hukum Investasi di Indonesia: Anatomi Undang-Undang No. 25 Tahun 2007 Tentang Penanaman Modal. Jakarta: Fakultas Hukum Unversitas Al-Azhar Indonesia, 2007.

Sembiring, Sentosa. Hukum Investasi: Pembahasan Dilengkapi dengan Undang-Undang Nomor 25 Tahun 2007 tentang Penanaman Modal. Bandung: CV. Nuansa Aulia, 2007.

Siti Anisah, Lucky Suryo Wicaksono. Hukum Investasi. Yogyakarta: FH UII Press, 2007.

Sutrisno, Salim HS dan Budi. Hukum Investasi di Indonesia. Jakarta: PT RajaGrafindo Persada, 2014.

\section{Internet:}

Nugroho, Wisnu. Kebijakan Ekonomi Indonesia 100 Persen Liberal. Bisnis \& Keuangan Media Daring, Jakarta: https://nasional.kompas.com/read/2009/06/09/1331383 3/Kebijakan.Ekonomi.Indonesia.100.Persen.Liberal, 2009.

Nugroho, Wisnu. Neoliberalisme. Media Daring, Jakarta: https://edukasi.kompas.com/read/2009/06/12/05541479 /.neoliberalisme, 2009. 
Qorib, Fathan. Penerapan Liberalisasi dalam RUU PM Tidak Tepat. Berita Media Daring, Jakarta: https://www.hukumonline.com/berita/baca/hol15450/p enerapan-liberalisasi-dalam-ruu-pm-tidak-tepat, 2006.

Rudi Hartono, Rini. Legalisasi Neokolonialisme. Artikel Media Daring, Jakarta: http://www.berdikarionline.com/legalisasi-neokolonialis me/, 2012. 


\section{POLITIK HUKUM PENAGGULANGAN TINDAK PIDANA TERORISME DI INDONESIA}

\section{Ade Riyanda Prasetia Putra}

Dosen Luar Biasa Fakultas Syariah Universitas Islam Negeri Sultan Thaha Saifuddin Jambi

JL Jambi - Muara Bulian KM 16, Simp Sei Duren Muara Jambi, Beringin, Kec. Ps. Jambi, Kota Jambi

Email: adeyanda059@gmail.com

\section{A. Pendahuluan}

Pada tanggal 11 September 2001, ada kejadian mahadahsyat yang menggemparkan dunia yaitu peristiwa peledakan menara kembar World Trade Center (WTC) dan Pentagon di Kota New York, Amerika Serikat. WTC adalah pusat perdagangan saham sedangkan Pentagon adalah Markas Besar Pertahanan Amerika Serikat. Ribuan orang yang mayoritas warga negara Amerika Serikat harus meregang nyawa karena menjadi korban kebiadaban pelaku penyerangan tersebut. Tak pelak peristiwa ini seperti tamparan bagi negara adidaya sekaliber Amerika Serikat karena pada kenyataan Negeri Paman Sam itu adalah negara yang memiliki fasilitas canggih jika dibandingkan dengan negara-negara lain di dunia. Kecanggihan teknologinya sangat termasyur sehingga untuk mendeteksi pelaku kejahatan yang akan menyerang warga negaranya bukan sesuatu yang sulit bagi mereka. Namun peristiwa 11 September seakan menjadi koreksi adidaya itu, bahwa pelaku kejahatan atau teror bisa datang kapan saja dengan segala fasilitas yang dimilikinya pula. ${ }^{295}$

Setahun pasca peledakan WTC dan Pentagon, tepatnya 12 Oktober 2002, di Indonesia terjadi peristiwa yang serupa bahkan tidak kalah dahsyatnya yakni peristiwa yang serupa

295 Hariman Satria, Anatomi Hukum Pidana Khusus, (Yogyakarta: UII Press, 2014), hlm. 95. 
bahkan tidak kalah dahsyatnya yakni peristiwa peledakan Paddys Cape dan Sari Club, di Jalan Legian, Kuta Bali kemudian dikenal dengan Bom Bali I. Peristiwa tersebut menewaskan lebih dari dua ratus jiwa dan melukai ratusan orang lainnya. Di antara korban tersebut warga negara asing yang paling banyak adalah berasal dari Australia serta sebagian lagi dari Amerika. Kejadian ini mendorong Amerika Serikat dan sekutunya seperti Australia, mendesak Pemerintah Indonesia untuk menangani secara serius di Pulau Dewata tersebut. Oleh karena tekanan dunia Internasional, Presiden Megawati menandatangani Peraturan Pemerintah Pengganti Undang-Undang Nomor 1 Tahun 2002 tentang Pemberantasan Tindak Pidana Terorisme (selanjutnya disebut Perppu Pemberantasan Tindak Pidana Terorisme) yang kemudian pada masa sidang DPR setahun berikutnya, ditetapkan sebagai Undang-Undang. 296

Menurut Prof. Muladi terorisme merupakan kejahatan luar biasa yang membutuhkan pula penangan dengan mendayagunakan cara-cara luar biasa karena berbagai hal:

1. Terorisme merupakan perbuatan yang menciptakan bahaya terbesar terhadap hak asasi manusia. Dalam hal ini hak asasi manusia untuk hidup dan hak asasi untuk bebas dari rasa takut;

2. Target terorisme bersifat random atau indiscriminate yang cenderung mengorbankan orang-orang tidak bersalah;

3. Kemungkinan digunakannya senjata-senjata pemusnah massal dengan memanfaatkan teknologi modern;

4. Kecenderungan terjadinya sinergi negatif antar organisasi terorisme nasional dengan organisasi internasional;

5. Kemungkinan kerjasama antara organisasi teroris dengan kejahatan yang terorganisasi baik yang bersifat nasional maupun transnasional;

6. Dapat membahayakan perdamaian dan keamanan internasional. 
Pada perkembangannya pencegahan dan pemberantasan tindak pidana terorisme di Indonesia tidak semata-mata ditinjau dari masalah hukum yang hanya dilakukan melalui kebijakan-kebijakan yang dirumuskan dalam undang-undang (atau yang dikenal dengan istilah kebijakan penal) saja, tetapi juga harus diimbangi dengan kebijakan-kebijakan non penal dalam upaya pencegahan tindak pidana terorisme. Permasalahan di luar politik hukum yang terdapat dalam undang- undang seperti masalah ekonomi dan sosial budaya berkaitan erat dengan masalah ketahanan bangsa sehingga kebijakan dan langkah pencegahan dan pemberantasannya-pun ditujukan untuk memelihara keseimbangan dalam kewajiban melindungi kedaulatan negara, hak asasi korban dan saksi, serta hak asasi tersangka/terdakwa. Pada tulisan ini terminologi yang dipakai adalah "Politik Hukum Pidana" dalam mengkaji penanggulangan tindak pidana terorisme. Istilah "kebijakan" dalam tulisan ini diambil dari istilah "policy" (Inggris) atau "politiek" (Belanda). Bertolak dari kedua istilah asing ini, maka istilah "kebijakan hukum pidana". Dalam kepustakaan asing istilah "politik hukum pidana" ini sering dikenal dengan berbagai istilah, antara lain "penal policy", "criminal law policy" atau "strafrechts politiek". 297 Pengertian kebijakan atau politik hukum pidana hukum pidana dapat dilihat dari politik maupun dari politik kriminal. Menurut Prof. Sudarto " Politik Hukum" adalah:

a. Usaha untuk mewujudkan peraturan-peraturan yang baik sesuai dengan keadaan dan situasi pada suatu saat; ${ }^{298}$

b. Kebijakan dari negara melalui badan-badan yang berwenang untuk menetapkan peraturan-peraturan yang dikehendaki yang diperkirakan bisa digunakan untuk mengekspresikan apa yang terkandung dalam masyarakat dan untuk mencapai apa yang dicita-citakan. ${ }^{299}$

297 Barda Nawawi Arief, Bunga Rampai Kebijakan Hukum Pidana: Perkembangan Penyusunan Konsep KUHP Baru, (Jakarta: Kencana, 2017), hlm. 26.

298 Sudarto, Hukum dan Hukum Pidana, (Bandung: Alumni, 1981), hlm. 159.

299 Sudarto, Hukum Pidana dan Perkembangan Masyarakat, (Bandung: Sinar Baru, 1983), hlm. 20. 
Bertolak dari pengertian demikian Prof. Sudarto selanjutnya menyatakan, bahwa melaksanakan "politik hukum pidana" berarti mengadakan pemilihan untuk mencapai hasil perundang-undangan pidana yang paling baik dalam arti memenuhi syarat keadilan dan daya guna. ${ }^{300}$ Dalam kesempatan lain beliau menyatakan, bahwa melaksanakan "politik hukum pidana" berarti, "usaha mewujudkan peraturan perundang-undangan pidana yang sesuai dengan keadaan dan situasi pada suatu waktu dan untuk masa-masa yang akan datang. ${ }^{301}$ Dengan demikian, dilihat sebagai bagian dari politik hukum, maka politik hukum pidana mengandung arti, bagaimana mengusahakan atau membuat atau membuat dan merumuskan suatu perundang-undangan pidana yang baik. Berdasarkan uraian tersebut, menarik untuk menelusuri secara holistik terkait Politik Hukum Penaggulangan Tindak Pidana Terorisme di Indonesia?

\section{B. Pandangan Umum Politik Hukum}

Secara etimologis politik hukum berasal dari padanan kata "politik" dan "hukum" itu sendiri. Kata politik menurut Prof. Miriam adalah usaha menggapai kehidupan yang baik. Filusuf seperti Plato dan Aristoteles menganggap politics sebagai suatu usaha untuk mencapai masyarakat politik (polity) yang terbaik. Sedangkan definisi hukum menurut Prof. Sudikno Mertokusumo adalah keseluruhan kumpulan peraturanperaturan atau kaidah-kaidah dalam suatu kehidupan bersama: keseluruhan peraturan tentang tingkah laku yang berlaku dalam suatu kehidupan bersama, yang dapat dipaksakan pelaksanaannya dengan suatu sanksi. 302 Dalam perkembangannya para ahli hukum dalam mendefinisikan hukum dengan definisi yang berbeda-beda. Imanuel Kant pernah mengatakan bahwa "Noch such die Juristen eine Definition zu ihrem begrife von recht" (masih saja para ahli hukum mencari

300 Sudarto, Hukum dan...,Op.cit, hlm.161.

301 Sudarto, Hukum Pidana dan......,Op.cit, hlm. 93.

302 Sudikno Mertokusumo, Mengenal Hukum: Suatu Pengantar, (Yogyakarta: Cahaya Atma Pustaka, 2010), hlm. 49. 
definisi mengenai pengertian hukum).

Padmo Wahjono mengatakan bahwa politik hukum adalah kebijakan dasar yang menentukan arah, bentukm maupun isi hukum yang dibentuk. ${ }^{303}$ Dalam tulisannya yang lain Padmo Wahjono memperjelas definisi tersebut dengan mengatakan bahwa politik hukum adalah kebijakan penyelenggara negara tentang apa yang dijadikan kriteria untuk menghukumkan sesuatu yang di dalamnya mencakup pembentukan, penerapan, dan penegakan hukum. ${ }^{304}$ Politik Hukum menurut Teuku Mohammada Radhie adalah sebagai bentuk pernyataan kehendak penguasa negara mengenai hukum yang berlaku di wilayahnya dan mengenai arah perkembangan hukum yang dibangun. ${ }^{305}$ Abdul Hakim Garuda dalam makalahnya yang berjudul "Politik Hukum Nasional" yang disampaikan pada Karya Latihan Bantuan Hukum (Kalabahu), memberikan pengertian politik hukum sebagai kebijakan hukum (legal policy) yang hendak diterapkan atau dilaksanakan secara nasional oleh suatu pemerintahan negara tertentu. 306

Dari berbagai definisi tentang politik hukum yang diberikan oleh para ahli. Prof Mahfud MD, mengatakan bahywa politik hukum adalah legal policy atau garis (kebijakan) resmi tentang hukum yang akan diberlakukan baik dengan pembuatan hukum baru maupun dengan penggantian hukum lama, dalam rangka mencapai tujuan negara." Dengan demikian, politik hukum merupakan pilihan hukumhukum yang akan dicabut atau tidak diberlakukan yang kesemuanya dimaksudkan untuk mencapai tujuan negara seperti tercantum

303 Padmo Wahjono, Indonesia Negara Berdasarkan Atas Hukum, (Jakarta: Ghalia Indonesia, 1986), hlm. 160.

304 Padmo Wahjono, "Menyelisik Proses Terbentuknya Peraturan Perundang-undangan", dalam Majalah Forum Keadilan, No. 29, April 1991, hlm. 65.

305 Teuku Mohammada Radhie, " Pembaharuan dan Politik Hukum Dalam Rangka Pembangunan Nasional”, Jurnal Prisma, Nomor 6 Tahun II Desember 1973, hlm. 4 .

306 Abdul Hakim Garuda, "Politik Hukum Nasional", makalah disampaikan pada Karya Latihan Bantuan Hukum (Kalabahu), diselenggarakan Yayasn Lembaga Bantuan Hukum Indonesia dan Lembaga Bantuan Hukum Surabaya, September 1985. 
di dalam pembukaan UUD 1945. ${ }^{307}$

Politik dan hukum mempunyai hubungan satu sama lain. Sri Soemantri pernah mengonstatasi hubungan antara hukum dan politik Indonesia ibarat perjalanan lokmotif karena kereta api yang keluar dari relnya. Jika hukum diibaratkan rel dan politik diibaratkan lokomotif maka sering terlihat lokomotif itu keluar dari rel yang seharusnya dilalui. ${ }^{308}$ Prinsip (atau sekedar semboyan) yang menyatakan politik dan hukum harus bekerja sama dan saling menguatkan melalui ungkapan "hukum tanpa kekuasaan adalah angan-angan, kekuasaan tanpa hukum kelaliman", menjadi semacam utopi belaka. ${ }^{309}$

Penulis akan mengerucutkan politik hukum dalam lingkup hukum pidana yakni politik hukum pidana. Sebagaimana telah dikemukakan sebelumnya Pengertian kebijakan atau politik hukum pidana hukum pidana dapat dilihat dari politik maupun dari politik kriminal. Prof. Sudarto “ Politik Hukum" adalah:

1. Usaha untuk mewujudkan peraturan-peraturan yang baik sesuai dengan keadaan dan situasi pada suatu saat; $; 10$

2. Kebijakan dari negara melalui badan-badan yang berwenang untuk menetapkan peraturan-peraturan yang dikehendaki yang diperkirakan bisa digunakan untuk mengekspresikan apa yang terkandung dalam masyarakat dan untuk mencapai apa yang dicita-citakan. ${ }^{311}$

Bertolak dari pengertian demikian Prof. Sudarto selanjutnya menyatakan, bahwa melaksanakan "politik hukum pidana" berarti mengadakan pemilihan untuk mencapai hasil perundang-undangan pidana yang paling baik dalam arti memenuhi syarat keadilan dan daya guna. ${ }^{312}$ Dalam kesempatan lain beliau menyatakan, bahwa melaksanakan "politik hukum

307 Moh. Mahfud MD, Politik Hukum di Indonesia, (Jakarta: Rajawali Pers, 2017), hlm. 1.

\footnotetext{
308 Ibid.

309 Ibid.

310 Sudarto, Hukum dan ....., Loc.Cit

311 Sudarto, Hukum Pidana dan Perkembangan...Loc.Cit.

312 Sudarto, Hukum dan...,Op.Cit, hlm.161.
} 
pidana" berarti, "usaha mewujudkan peraturan perundang-undangan pidana yang sesuai dengan keadaan dan situasi pada suatu waktu dan untuk masa-masa yang akan datang. ${ }^{313}$

Dengan demikian, dilihat sebagai bagian dari politik hukum, maka politik hukum pidana mengandung arti, bagaimana mengusahakan atau membuat atau membuat dan merumuskan suatu perundang-undangan pidana yang baik. Pengertian demikian terlihat pula dalam definisi "penal policy" dari Marc Ancel yang telah dikemukakan pada uraian pendahuluan yang secara singkat dapat dinyatakan sebagai "suatu ilmu sekaligus seni yang bertujuan untuk memungkinkan peraturan hukum positif dirumuskan secara lebih baik". Dengan demikian yang dimaksud "peraturan hukum positif" (the positive rules) dalam definisi Marc Ancel itu jelas adalah peraturan perundang-undangan dengan hukum pidana. Dengan demikian, istilah "penal policy" menurut Marc Ancel adalah sama dengan istilah "kebijakan atau politik hukum pidana".

Lebih lanjut menurut A. Mulder "Strafrechttspolitiek" adalah garis kebijakan untuk menentukan: ${ }^{314}$

1. Seberapa jauh ketentuan-ketentuan pidana yang berlaku perlu diubah atau diperbarui;

2. Apa yang dapat diperbuat untuk mencegah terjadinya tindak pidana;

3. Cara bagaimana penyidikan, penentuan, peradilan dan pelaksanaan pidana harus dilaksnakan.

Definisi Mulder di atas bertolak dari pengertian "sistem hukum pidana" menurut Marc Ancel yang menyatakan, bahwa tiap masyarakat yang teroganisir memiliki sistem hukum pidana terdiri dari: (a) peraturan-peraturan hukum pidana dan sanksinya; (b) suatu prosedur hukum pidana; dan (c) suatu

313 Sudarto, Hukum Pidana dan......,Op.Cit, hlm. 93.

314 A. Mulder, "Strafrechtpolitiek", Delikt en Delinkwent, lihat Barda Nawawi Arief, Bunga Rampai Kebijakan Hukum Pidana..., Op.Cit, hlm. 27. 
mekanisme pelaksanaan (pidana). ${ }^{315}$

Menurut Barda Nawawi Arief, usaha dan kebijakan untuk membuat peraturan hukum pidana yang baik pada hakikatnya tidak dapat dilepaskan dari tujuan penanggulangan kejahatan. Jadi kebijakan atau politik hukum pidana juga merupakan bagian dari politik kriminal. Dengan perkataan lain, dilihat dari sudut politik kriminal, maka politik hukum pidana identik dengan pengertian "kebijakan penanggulangan kejahatan dengan hukum pidana". Usaha penanggulangan kejahatan dengan hukum pidana pada hakikatnya juga merupakan bagian dari usaha penegakan hukum (khususnya penegakan hukum pidana). Oleh karena itu, sering pula dikatakan bahwa politik atau kebijakan hukum pidana merupakan bagian pula dari kebijakan penegakan hukum (law enforcement policy). ${ }^{316}$

\section{Penanggulangan Kejahatan}

G. P Hoefnagels ${ }^{317}$ menguraikan beberapa upaya penanggulangan kejahatan, yaitu; penerapan hukum pidana (criminal law application); pencegahan tanpa pidana (prevention without punishment);mempengaruhi pandangan masyarakat tentang kejahatan; dan pemidanaan melalui media masa ( influencing views of society on crime and punishment/mass media). Berdasarkan pendapat G P. Hoefnagels 318 di atas dapat disimpulkan bahwa penanggulangan kejahatan secara umum dapat ditempuh melalui dua pendekatan yaitu penal dan non penal. Keduanya dalam fungsinya harus berjalan beriringan secara sinergis, saling melengkapi. Jika pendekatan pertama yang ditempuh, maka ini berarti bahwa penanggulangan suatu kejahatan dilakukan dengan menggunakan kebijakan hukum pidana (penal policy/criminal law policy/strafrechtspolitiek), yaitu, "usaha mewujudkan peraturan perundang-undangan pidana

315 Ibid.

316 Ibid.

317 Barda Nawawi Arief, Bunga Rampai Kebijakan Hukum Pidana, (Bandung: Citra Aditya Bakti, 2002), hlm. 1.

318 Ibid., hlm 28. 
yang sesuai dengan keadaan dan situasi pada suatu waktu dan untuk masa yang akan datang". Artinya, hukum pidana difungsikan sebagai sarana pengendali sosial, yaitu dengan sanksinya yang berupa pidana untuk dijadikan sarana, menanggulangi kejahatan. Sedangkan upaya non penal dapat ditempuh dengan melakukan pendekatan agama, budaya/kultural, moral/edukatif sebagai upaya preventif dengan melakukan serangkaian program kegiatan dengan fokus pengkuatan, penanaman nilai budi pekerti yang luhur, etika sosial, serta pemantapan keyakinan terhadap agama melalui pendidikan agama.

Secara kasar dapatlah dibedakan, bahwa upaya penanggulangan kejahatan lewat jalur "penal" lebih menitikberatkan pada sifat "repressive" (penindasan/ pemberantasan/penumpasan) sesudah kejahatan terjadi, sedangkan jalur "non penal" lebih menitikberatkan pada sifat "preventive" (pencegahan/ penangkalan/ pengendalian) sebelum kejahatan terjadi. Dikatakan sebagai perbedaan secara kasar, karena tindak represif pada hakikatnya juga dapat dilihat sebagai tindakan preventif dalam arti luas.

Kejahatan atau tidak kriminal merupakan bentuk perilaku yang menyimpang dari kebiasaan masyarakat atau anti sosial. Perilaku menyimpang ini sangat menganggu tatanan kehidupan sosial yaitu ancaman yang nyata terhadap norma-norma sosial yang mendasari keteraturan sosial. Kejahatan tersebut dapat menimbulkan ketegangan individu maupun sosial, hal itu disebabkan terlanggarnya hak-hak yang dimiliki oleh individu dan masyarakat.. ${ }^{319}$

Beberapa dekade terakhir berkembang ide-ide perbuatan tanpa pidana, artinya tidak semua tindak pidana menurut undang-undang pidana dijatuhkan pidana, serentetan pendapat dan beberapa hasil penelitian menemukan bahwa pemidanaan tidak memiliki kemanfaatan ataupun tujuan, pemidanaan tidak menjadikan lebih baik. Karena itulah

319 Salman Luthan, Kebijakan Kriminalisasi Di Bidang Keuangan, (Yogyakarta: UII Press, 2014), hlm. 14. 
perlunya sarana nonpenal diintensifkan dan diefektifkan, di samping beberapa alasan tersebut, juga masih diragukannya atau dipermasalahkannya efektifitas sarana penal dalam mencapai tujuan politik kriminal.

Mengingat upaya penanggulangan kejahatan lewat jalur "non penal" lebih bersifat tindakan pencegahan untuk terjadinya kejahatan, maka sasaran utamanya adalah menangani faktor-faktor kondusif penyebab terjadinya kejahatan. Faktor-faktor kondusif itu antara lain berpusat pada masalah-masalah atau kondisi-kondisi sosial yang secara langsung atau tidak langsung dapat menimbulkan atau menumbuhsuburkan kejahatan. Dengan demikian, dilihat dari sudut politik kriminal secara makro dan global, maka upaya-upaya non penal menduduki posisi kunci dan strategis dari keseluruhan upaya politik kriminal.

Barda Nawawi Arief mengemukakan bahwa kebijakan atau upaya penanggulangan kejahatan pada hakikatnya merupakan bagian integral dari upaya perlindungan masyarakat (social defence) dan upaya mencapai kesejahteraan masyarakat (social welfare). Oleh karena itu, dapat dikatakan bahwa tujuan akhir atau tujuan utama dari politik kriminal ialah perlindungan masyarakat untuk mencapai kesejahteraan masyarakat. ${ }^{320}$

Bila dalam kebijakan penanggulangan tindak pidana atau politik kriminal digunakan upaya/sarana hukum pidana (penal), maka kebijakan hukum pidana harus diarahkan pada tujuan dari kebijakan sosial (social policy) yang terdiri dari kebijakan/upaya-upaya untuk kesejahteraan sosial (social welfare policy) dan kebijakan/upaya-upaya untuk perlindungan masyarakat (social defence policy).

Sehubungan dengan hal tersebut Marc Ancel sebagaimana dikutip oleh Barda Nawawi Arief dan Muladi menyatakan bahwa : hlm. 4.

${ }^{320}$ Barda Nawawi Arief, Bunga Rampai Kebijakan Hukum Pidana....., Op.Cit, 
"Tiap masyarakat mensyaratkan adanya tertib sosial, yaitu seperangkat peraturan-peraturan yang tidak hanya sesuai dengan kebutuhan untuk kehidupan bersama tetapi juga sesuai dengan aspirasi-aspirasi warga masyarakat pada umumnya. Oleh karena itu peranan yang besar dari hukum pidana merupakan kebutuhan yang tak dapat dielakkan bagi suatu sistem hukum. Perlindungan individu maupun masyarakat tergantung pada perumusan yang tepat mengenai hukum pidana yang mendasari kehidupan masyarakat itu sendiri. Oleh karena itu sistem hukum pidana, tindak pidana, penilaian hakim terhadap si pelanggar dalam hubungannya dengan hukum secara murni maupun pidana merupakan lembaga-lembaga (institusi) yang harus tetap dipertahankan. Hanya saja dalam menggunakan hukum pidana Marc Ancel menolak penggunaan fiksi-fiksi yuridis dan teknik-teknik yuridis yang terlepas dari pernyataan sosial."

Dengan demikian dapat dikatakan, bahwa politik kriminal pada hakikatnya juga merupakan bagian integral dari politik sosial (yaitu kebijakan atau upaya untuk mencapai kesejahteraan sosial). Penegakan hukum dengan sarana penal merupakan salah satu aspek saja dari usaha masyarakat menanggulangi kejahatan. Disamping itu masih dikenal usaha masyarakat menanggulangi kejahatan melalui sarana non penal. Usaha non penal dalam menanggulangi kejahatan sangat berkaitan erat dengan usaha penal. Upaya non penal ini dengan sendirinya akan sangat menunjang penyelenggaraan peradilan pidana dalam mencapai tujuannya. Pencegahan atau atau menanggulangi kejahatan harus dilakukan pendekatan integral yaitu antara sarana penal dan non penal.

Menurut G.F Hoefnagels upaya penanggulangan yang merupakan bagian dari kebijakan sosial pada hakikatnya juga merupakan bagian integral dari upaya perlindungan masyarakat (social defence) yang dapat ditempuh dengan 2 jalur, yaitu: 321

1. Jalur penal, yaitu dengan menerapkan hukum pidana (criminal law application);

321 Ibid. 
2. Jalur non penal, yaitu dengan cara :

a. Pencegahan tanpa pidana (prevention without punisment), termasuk di dalamnya penerapan sanksi administrative dan sanksi perdata;

b. Mempengaruhi pandangan masyarakat mengenai kejahatan dan pembinaan lewat media massa (influencing views of society on crime and punishment).

Apabila dilihat dari sudut kebijakan kriminal, upaya penanggulangan kriminalitas dengan menggunakan sarana penal saja bukan kebijakan yang strategis, karena kebijakan penal mempunyai keterbatasan dan mengandung beberapa kelemahan (sisi-sisi negatif) antara lain: ${ }^{322}$

1. Sebab-sebab kejahatan yang demikian kompleks berada diluar jangkauan hukum pidana;

2. Hukum pidana hanya merupakan bagian kecil (sub-sistem) dari sarana kontrol sosial yang tidak mungkin mengatasi masalah kejahatan sebagai masalah kemanusiaan dan kemasyarakatan yang sangat kompleks (sebagai masalah sosio-psikologis, sosio-politik, sosio-ekonomi, dan sebagainya);

3. Penggunaan hukum pidana dalam menanggulangi kejahatan hanya merupakan "kurieren am symptom". Oleh karena itu, hukum pidana hanya merupakan " pengobatan simptomatik" dan bukan "pengobatan kausatif";

4. Sanksi hukum pidana merupakan "remidium" yang mengandung sifat kontradiktif/paradoksal dan mengandung unsur - unsur serta efek samping negatif;

5. Sistem pemidanaan bersifat fragmentair dan individual/personal, tidak bersifat struktural/fungsional;

6. Keterbatasan jenis sanksi dan sistem perumusan sanksi pidana yang bersifat kaku dan imperatif;

322 Barda Nawawi Arief, Beberapa Aspek Kebijakan Penegakan dan Pengembangan Hukum Pidana, (Bandung: Citra Aditya Bakti, 2005), hlm 74-75. 
7. Bekerjanya/berfungsinya hukum pidana memerlukan sarana pendukung yang lebih bervariasi dan lebih menuntut "biaya tinggi".

Mengingat upaya penanggulangan kejahatan lewat jalur "non penal" lebih bersifat tindakan pencegahan untuk terjadinya kejahatan, maka sasaran utamanya adalah menangani faktor-faktor kondusif penyebab terjadinya kejahatan.

Contoh Kebijakan Penal antara lain kasus pencurian satu buah semangka oleh 2 (dua) warga Kelurahan Bujel, Kecamatan Mojoroto, Kota Kediri, atas nama Basar dan Kholil yang didakwa melakukan tindak pidana pencurian sebuah semangka milik tetangganya. Saat tertangkap semangka curian belum sempat dimakan, proses hukum tetap dilanjutkan dan keduanya dijerat Pasal 362 KUHP dengan ancaman hukuman 5 (lima) tahun penjara. Meski tindak pidana yang dilakukan Basar dan Kholil secara materil dan formil telah memenuhi unsur pencurian dengan melangagar Pasal 362 KUHP. Meski begitu penyelesaiannya semestinya dapat dilakukan di tingkat kepolisian. Dengan mempertimbangkan bobot perkara yang dianggap sangat rendah dan didukung dengan barang bukti yang sangat sepele, semestinya penyelesaian dapat dilakukan atas dasar kemanusiaan. Kasus ini dilanjut sampai pengadilan karena kejaksaan tidak mungkin menolak limpahan berkas dari kepolisian. Apalagi tindak pidananya memang sudah memenuhi unsur pelanggaran Pasal 362 KUHP. Untuk tindak pidana yang dilakukan Basar dan Kholil dianggap sangat sepele karena nilai barang curian yang terlalu kecil.

Contoh Kebijakan Non Penal Beberapa masalah dan kondisi sosial yang dapat merupakan faktor kondusif penyebab timbulnya kejahatan, jelas merupakan masalah yang tidak dapat diatasi semata-mata dengan "penal". Di sinilah keterbatasan jalur "penal" dan oleh karena itu, harus ditunjang oleh jalur "non penal". Salah satu jalur "nonpenal" untuk mengatasi masalah-masalah sosial seperti dikemukakan di atas adalah lewat jalur "kebijakan sosial" (social policy). Yang dalam 
skema G.P. Hoefnagels di atas juga dimasukkan dalam jalur "prevention without punishment". Kebijakan sosial pada dasarnya adalah kebijakan atau upaya-upaya rasional untuk mencapai kesejahteraan masyarakat. Jadi identik dengan kebijakan atau perencanaan pembangunan nasional yang meliputi berbagai aspek yang cukup luas dari pembangunan.

Salah satu aspek kebijakan sosial yang kiranya patut mendapat perhatian ialah penggarapan masalah kesehatan jiwa masyarakat (social hygiene), baik secara individual sebagai anggota masyarakat maupun kesehatan/kesejahteraan keluarga (termasuk masalah kesejahteraan anak dan remaja), serta masyarakat luas pada umumnya. Penggarapan masalah "mental health", "national mental health" dan "child welfare" ini pun dikemukakan dalam skema Hoefnagels di atas sebagai salah satu jalur ("prevention of crime without punishment") (jalur "nonpenal"). Prof. Sudarto pernah juga mengemukakan, bahwa "kegiatan karang taruna, kegiatan Pramuka dan penggarapan kesehatan jiwa masyarakat dengan pendidikan agama" merupakan upaya-upaya non penal dalam mencegah dan menanggulangi kejahatan.

Barda Nawawi mengemukakan pola hubungan antar kebijakan hukum pidana (penal policy) dengan upaya penanggulangan kejahatan, beliau mengatakan bahwa pencegahan dan penanggulangan kejahatan harus dilakukan denga pendekatan integral dan ada keseimbangan antara penal dan non penal. Pencegahan dan pendekatan kejahatan dengan sarana penal merupaka penal policy atau Penal law Enforcement policy, yang fungsionalisasinya melalui beberapa tahap seperti tahap Formulasi (kebijakan legislatif), Aplikasi (kebijakan yudikatif) dan Eksekusi (kebijakan Administratif). ${ }^{323}$

\section{Politik Hukum Penanggulangan Tindak Pidana Terorisme}

Dalam kamus Oxford School Dictionary \& Thesaurus, teror adalah usaha menciptakan ketakutan yang sangat dalam oleh hlm. 2.

${ }^{323}$ Barda Nawawi Arief, Bunga Rampai Kebijakan Hukum Pidana......, Op.Cit, 
seseorang atau kelompok. Teroris adalah orang yang menggunakan kekerasan untuk menimbulkan rasa takut, biasanya untuk tujuan politik. Terorisme adalah penggunaan penggunaan kekerasan untuk menimbulkan ketakutan dalam usaha mencapai tujuan. ${ }^{324}$ Istilah terorisme menurut Paul Wilkinson adalah aksi teror yang sistematis, rapi, dan dilakukan oleh organisasi tertentu. ${ }^{325} \mathrm{Hafid}$ Abbas terorisme adalah pemakaian kekuatan atau kekerasan tidak sah melawan orang atau properti untuk mengintimidasi atau menekan pemerintah, masyarakat sipil atau bagian-bagiannya untuk memaksa tujuan sosial dan politik. ${ }^{326}$

Lebih lanjut, menurut James Adams, menyatakan bahwa terorisme adalah penggunaan atau ancaman kekerasan fisik oleh individu-individu atau kelompok-kelompok untuk tujuan politik, baik untuk kepentingan atau melawan kekuasaan yang ada apabila tindakan-tindakan terorisme dimaksudkan untuk mengejutkan, melumpuhkan atau mengintimidasi suatu kelompok atau sasaran yang lebih besar daripada korban-korban secara langsung. Menurut Central Intelegence Agency (CIA), terorisme adalah ancaman atau penggunaan kekerasan untuk tujuan politik yang dilakukan oleh individu atau kelompok, atas nama atau menentang pemerintah sah, dengan menakut-nakuti masyarakat yang lebih luas daripada korban langsung teroris. ${ }^{327}$

Kendati tidak diatur secara eksplisit dalam ketentuan umum Perppu Pemberantasan Tindak Pidana Terorisme, namun yang dimaksud tindak pidana terorisme adalah setiap tindakan dari seseorang yang dengan sengaja menggunakan kekerasan atau ancaman kekerasan menimbulkan suasana teror atau rasa takut terhadap orang secara meluas atau

324 Robert Allen, Oxford School Dictionary \& Thesaurus (Oxford: Oxford University Press, 2005), hlm. 705.

325 Wahid Sunardi dan Imam Siddiq, Kejahatan Terorisme Perspektif Agama, Haka Asasi Manusia dan Hukum, (Bandung: Refika Aditama, 2004), hlm. 29.

${ }^{326}$ Hermawan Sulistyo, Beyond Terorism, (Jakarta: Pustaka Sinar Harapan, 2002), hlm. 3.

327 Mahrus Ali, Hukum Pidana Terorisme: Teori dan Praktik,( Jakarta: Gramata Publishing, 2012), hlm. 3. 
menimbulkan korban yang bersifat massal, dengan cara merampas kemerdekaan atau hilangnya nyawa dan harta benda orang lain, atau mengakibatkan kerusakan atau kehancuran terhadap obyek-obyek vital yang strategis atau lingkungan hidup atau fasilitas publik atau fasilitas internasional. ${ }^{328}$

Definisi mengenai terorisme diatur secar ekplisit dalam ketentuan umum sebagaimana disebutkan dalam Pasal 1 angka 2 Undang-Undang Nomor 5 Tahun 2018 Tentang Perubahan Atas Undang-Undang Nomor 15 Tahun 2003 tentang Penetapan Peraturan Pemerintah Pengganti Undang-Undang Nomor 1 Tahun 2002 tentang Pemberantasan Tindak Pidana Terorisme Menjadi Undang-Undang, yang bunyinya terorisme adalah perbuatan yang menggunakan kekerasan atau ancaman kekerasan yang menimbulkan suasana teror atau rasa takut secara meluas, yang dapat menimbulkan korban yang bersifat massal, dan/atau menimbulkan kerusakan atau kehancuran terhadap objek vital strategis, lingkungan hidup, fasilitas publik, atau fasilitas internasional dengan motif ideologi, politik, atau gangguan keamanan.

Yang dimaksud kekerasan adalah sebagai setiap perbuatan penyalahgunaan kekuatan fisik dengan atau tanpa menggunakan sarana secara melawan hukum dan menimbulkan bahaya bagi badan, nyawa, dan kemerdekaan orang, termasuk menjadikan orang pingsan atau tidak berdaya. ${ }^{329}$ Selanjutnya yang dimaksud dengan ancaman kekerasan adalah setiap perbuatan secara melawan hukum berupa ucapan, tulisan, gambar, simbol atau gerakan tubuh, baik dengan maupun tanpa menggunakan sarana dalam bentuk elektronik atau non elektronik yang dapat menimbulkan rasa takut terhadap orang atau masyarakat

328 Pasal 6 Peraturan Pemerintah Pengganti Undang-Undang Nomor 1 Tahun 2002 tentang Pemberantasan Tindak Pidana Terorisme.

329 Pasal 1 angka 3 Undang-Undang Nomor 5 Tahun 2018 Tentang Perubahan Atas Undang-Undang Nomor 15 Tahun 2003 tentang Penetapan Peraturan Pemerintah Pengganti Undang-Undang Nomor 1 Tahun 2002 tentang Pemberantasan Tindak Pidana Terorisme Menjadi Undang-Undang. 
secara luas atau mengekang kebebasan hakiki seseorang atau masyarakat. ${ }^{330}$

Ada dua pandangan terhadap kegiatan terorisme yang berkembang saat ini yaitu pertama, terorisme merupakan kegiatan yang bersifat politik, baik memiliki latar belakang politik, bertujuan politik, maupun kegiatan yang disponsori oleh kepentingan plitik. Pandangan lain, adalah bahwa kegiatan terorisme merupakan kegiatan kriminal yang sangat merugikan dan membahayakan kehidupan dan perdamaian bangsa. Kedua pandangan yang berbeda secara mendasar tersebut sudah tertentu, juga membawa perbedaan mengenai cara-cara pemberantasannya. Pandangan yang pertama sering disampaikan dengan justifikasi bahwa untuk mencegah dan memberantas terorisme perlu diungkapkan akan dari masalah terorisme. Pandangan kedua sering disampaikan dengan justifikasi "perlindungan global umat manusia" (global protection for humankind). ${ }^{331}$

Terorisme dapat dimengerti sebagai serangan-serangan terkordinasi yang bertujuan membangkitkan perasaan teror terhadap sekelompok masyarakat. Berbeda dengan perang, aksi terorisme tidak tunduk pada tata cara peperangan seperti waktu pelaksanaan yang selalu tiba-tiba dan target korban jiwa yang acak serta seringkali merupakan warga sipil. Istilah teroris oleh para ahli kontra terorisme merujuk kepada para pelaku yang tidak tergabung dalam angkatan bersenjata yang dikenal atau tidak menuruti peraturan angkatan bersenjata tersebut. Aksi terorisme juga mengandung makna bahwa serang-serangan teroris yang dilakukan tidak berprikemanusian dan tidak memiliki justifikasi. ${ }^{332}$

330 Pasal 1 angka 4 Undang-Undang Nomor 5 Tahun 2018 Tentang Perubahan Atas Undang-Undang Nomor 15 Tahun 2003 tentang Penetapan Peraturan Pemerintah Pengganti Undang-Undang Nomor 1 Tahun 2002 tentang Pemberantasan Tindak Pidana Terorisme Menjadi Undang-Undang.

331 Hery Firmansyah, "Upaya Penanggulangan Tindak Pidana Terorisme di Indonesia" , Jurnal Mimbar Hukum, Volume 23, Nomor 2, Juni 2011, hlm. 385.

332 Luh Nila Winarni, " Kebijakan Hukum Pidana Non Penal Dalam Penanggulangan Kejahatan Radikalisme Berbentuk Terorisme", Jurnal Ilmu Hukum DIH, Volume 12, Nomor 23, Februari 2016, hlm. 60. 
Rumusan Pasal 6 telah mengalami perubahan terkait hukuman terhadap pelaku yang dalam Pasal 6 Perppu Pemberantasan Tindak Pidana Terorisme pelaku dipidana dengan pidana mati atau penjara seumur hidup atau pidana penjara paling singkat 4 (empat) tahun dan paling lama 20 (dua puluh) tahun. Berdasarkan Pasal 6 Undang-Undang Nomor 5 Tahun 2018, pelaku dipidana dengan pidana penjara paling singkat 5 (lima) tahun dan paling lama 20 (dua puluh) tahun, pidana penjara seumur hidup, atau pidana mati.

Pasal 7 Perppu Pemberantasan Tindak Pidana Terorisme, menyebutkan bahwa setiap orang yang dengan sengaja menggunakan kekerasan atau ancaman kekerasan bermaksud untuk menimbulkan suasana teror atau rasa takut terhadap orang secara meluas atau menimbulkan korban yang bersifat massal dengan cara merampas kemerdekaan atau hilangnya nyawa atau harta benda orang lain, atau untuk menimbulkan kerusakan atau kehancuran terhadap obyek-obyek vital yang strategis, atau lingkungan hidup, atau fasilitas publik, atau fasilitas internasional, dipidana dengan pidana penjara paling lama seumur hidup.

Pasal 8 menyebutkan bahwa dipidana karena melakukan tindak pidana terorisme dengan pidana yang sama sebagaimana dimaksud dalam Pasal 6, setiap orang yang:

1. menghancurkan, membuat tidak dapat dipakai atau merusak bangunan untuk pengamanan lalu lintas udara atau menggagalkan usaha untuk pengamanan bangunan tersebut;

2. menyebabkan hancurnya, tidak dapat dipakainya atau rusaknya bangunan untuk pengamanan lalu lintas udara, atau gagalnya usaha untuk pengamanan bangunan tersbeut;

3. dengan sengaja dan melawan hukum menghacurkan, merusak, mengambil, atau memindahkan tanda atau alat untuk pengamanan penerbangan, atau menggagalkan bekerjanya tanda atau alat tersebut, atau memasang tanda atau alat yang keliru; 
4. karena kealpaannya menyebabkan tanda atau alat untuk pengamanan penerbangan hancur, rusak, terambil atau pindah atau menyebabkan terpasangnya tanda atau alat untuk pengamanan penerbangan yang keliru;

5. dengan sengaja atau melawan hukum, menghancurkan atau membuat tidak dapat dipakainya pesawat udara yang seluruhnya atau sebagian kepunyaan orang lain;

6. dengan sengaja dan melawan hukum mencelakakan, menghancurkan, membuat tidak dapat dipakai atau merusak pesawat udara;

7. karena kealpaannya menyebabkan pesawat udara celaka, hancur, tidak dapat dipakai, atau rusak;

8. dengan maksud untuk menguntungkan diri sendiri atau orang lain, dngan melawan hukum, atas penanggung asuransi menimbulkan kebakaran atau ledakan, kecelakaan kehancuran, kerusakan atau membuat tidak dapat dipakainya pesawat udara yang dipertanggungkan terhadap bahaya atau yang dipertanggungkan muatannya maupun upah yang akan diterima untuk pengangkutan muatannya, ataupun untuk kepentingan muatan tersebut telah diterima uang tanggungan;

9. dalam pesawat udara dengan perbuatan yang melawan hukum, merampas atau mempertahankan perampasan atau menguasai pesawat udara dalam penerbangan;

10. dalam pesawat udara dengan kekerasan atau ancaman kekerasan atau ancaman dalam bentuk lainnya, merampas atau mempertahankan perampasan atau menguasai pengendalian pesawat udara dalam penerbangan;

11. melakukan bersama-sama sebagai kelanjutan pemufakatan jahat, dilakukan dengan direncanakan terlebih dahulu, mengakibatkan luka berat seseorang, mengakibatkan kerusakan pada pesawat udara sehingga dapat membahayakan penerbangannya, dilakukan dengan maksud untuk merampas kemerdekaan atau meneruskan merampas kemerdekaan seseorang; 
12. dengan sengaja dan melawan hukum melakukan perbuatan kekerasan terhadap seseorang di dalam pesawat udara dalam penerbangan, jika perbuatan itu dapat membahayakan keselamatan pesawat udara tersebut;

13. dengan sengaja dan melawan hukum merusak pesawat udara

dalam dinas atau menyebabkan kerusakan atas pesawat udara tersebut yang menyebabkan tidak dapat terbang atau membahayakan keamanan penerbangan;

14. dengan sengaja dan melawan hukum menempatkan atau menyebabkan ditempatkannya di dalam pesawat udara dalam dinas, dengan cara apapun, alat atau bahan yang dapat menghancurkan pesawat udara yang membuatnya tidak dapat terbang atau menyebabkan kerusakan pesawat udara tersebut yang dapat membahayakan keamanan dalam penerbangan;

15. melakukan secara bersama-sama 2 (dua) orang atau lebih, sebagai kelanjutan dari permufakatan jahat, melakukan dengan direncanakan lebih dahulu, dan mengakibatkan luka berat bagi seseorang dari perbuatan sebagaimana dimaksud dalam huruf 1, huruf $\mathrm{m}$, dan huruf n;

16. memberikan keterangan yang diketahuinya adalah palsu dan karena perbuatan itu membahayakan keamanan pesawat udara dalam penerbangan;

17. di dalam pesawat udara melakukan perbuatan yang dapat membahayakan keamanan dalam pesawat udara dalam penerbangan;

18. di dalam pesawat udara melakukan perbuatan-perbuatan yang dapat mengganggu ketertiban dan tata tertib di dalam pesawat udara dalam penerbangan.

Pasal 9 Perppu Pemberantasan Tindak Pidana Terorisme menyebutkan setiap orang yang secara melawan hukum memasukan ke Indonesia, membuat, menerima, mencoba memperoleh, menyerahkan atau mencoba menyerahkan atau mencoba menyerahkan, menguasai, membawa, mempunyai 
persediaan padanya atau mempunyai dalam miliknya, menyimpan, mengangkut, menyembunyikan, mempergunakan, atau mengeluarkan ke dan/atau dari Indonesia sesuatu senjata api, amunisi, atau sesuatu bahan peledak dan bahan-bahan lainnya yang berbahaya dengan maksud untuk melakukan tindak pidana terorisme, dipidana dengan pidana mati atau penjara seumur hidup atau pidana penjara paling singkat 3 (tiga) tahun dan paling lama 20 (dua puluh) tahun.

Pasal 10 Perppu Pemberantasan Tindak Pidana Terorisme menyebutkan dipidana dengan pidana yang sama dengan pidana sebagaimana dimaksud dalam Pasal 6, setiap orang yang dengan sengaja menggunakan senjata kimia, senjata biologis, radiologi, mikrorganisme, radioaktif atau komponennya, sehingga menimbulkan suasana teror, atau rasa takut terhadap orang secara meluas, menimbulkan korban yang bersifat massal, membahayakan terhadap kesehatan, terjadi kekacauan terhadap kehidupan, keamanan, dan hak-hak orang, atau terjadi kerusakan, kehancuran terhadap obyek-obyek vital yang strategis, lingkungan hidup, fasilitas publik, atau fasilitas internasional.

Adapun beberapa Pasal a quo terlihat jelas bahwa penanggulangan terhadap tindak pidana terorisme mengutamakan pendekatan penal. Upaya penanggulangan kejahatan lewat jalur penal lebih menitikberatkan pada sifat "repressive" (penindasan/pemberantasan/penumpasan) sesudah kejahatan terjadi. Merujuk pada Perppu Pemberantasan Tindak Pidana Terorisme, pengaturan mengenai penanggulangan secara "non penal" tidak diatur secara lengkap dapat dilihat dalam Pasal 43 yang menyebutkan bahwa dalam rangka pencegahan dan pemberantasan tindak pidana terorisme, Pemerintah Republik Indonesia melaksanakan kerja sama internasional dengan negara lain di bidang intelejen, kepolisian dan kerjasama teknis lainnya yang berkaitan dengan tindakan melawan terorisme sesuai dengan ketentuan peraturan perundang-undangan yang berlaku. 
Dalam perkembangannya upaya penanggulangan tindak pidana terorisme dengan pendekatan non penal telah diatur secara jelas dan lengkap dalam Undang-Undang Nomor 5 Tahun 2018 (Revisi UU PemberantasanTerorisme). Berdasarkan Pasal 43A ayat (1) Pemerintah wajib melakukan pencegahan Tindak Pidana Terorisme. Pasal 43A ayat (2) menyebutkan dalam upaya pencegahan Tindak Pidana Terorisme, Pemerintah melakukan langkah antisipasi secara terus menerus yang dilandasi dengan prinsip perlindungan Hak Asasi Manusia dan prinsip kehati-hatian.

Pemerintah dalam melakukan pencegahan tindak pidana terorisme dengan 3 (tiga) metode yaitu: ${ }^{333}$ a. kesiapsiagaan nasional; b. kontra radikalisasi; dan c. deradikalisasi.

Kesiapsiagaan nasional merupakan suatu kondisi siap siaga untuk mengantisipasi terjadinya Tindak Pidana Terorisme melalui proses yang terencana, terpadu, sistematis, dan berkesinambungan. ${ }^{334}$ Kesiapsiagaan nasional dilakukan oleh Pemerintah. ${ }^{335}$ Untuk pelaksanaan kesiapsiagaan nasional dilakukan oleh kementerian/lembaga yang terkait di bawah koordinasi badan yang menyelenggarakan urusan di bidang penanggulangan. 336 Kesiapsiagaan nasional melalui pemberdayaan masyarakat, peningkatan kemampuan aparatur, perlindungan dan peningkatan sarana prasarana

333 Pasal 43A Ayat (3) Undang-Undang Nomor 5 Tahun 2018 Tentang Perubahan Atas Undang-Undang Nomor 15 Tahun 2003 tentang Penetapan Peraturan Pemerintah Pengganti Undang-Undang Nomor 1 Tahun 2002 tentang Pemberantasan Tindak Pidana Terorisme Menjadi Undang-Undang.

334 Pasal 43B Ayat (1) Undang-Undang Nomor 5 Tahun 2018 Tentang Perubahan Atas Undang-Undang Nomor 15 Tahun 2003 tentang Penetapan Peraturan Pemerintah Pengganti Undang-Undang Nomor 1 Tahun 2002 tentang Pemberantasan Tindak Pidana Terorisme Menjadi Undang-Undang.

335 Pasal 43B Ayat (2) Undang-Undang Nomor 5 Tahun 2018 Tentang Perubahan Atas Undang-Undang Nomor 15 Tahun 2003 tentang Penetapan Peraturan Pemerintah Pengganti Undang-Undang Nomor 1 Tahun 2002 tentang Pemberantasan Tindak Pidana Terorisme Menjadi Undang-Undang.

336 Pasal 43B Ayat (3) Undang-Undang Nomor 5 Tahun 2018 Tentang Perubahan Atas Undang-Undang Nomor 15 Tahun 2003 tentang Penetapan Peraturan Pemerintah Pengganti Undang-Undang Nomor 1 Tahun 2002 tentang Pemberantasan Tindak Pidana Terorisme Menjadi Undang-Undang 
pengembangan kajian terorisme, serta pemetaan wilayah rawan paham radikal terorisme. ${ }^{337}$

Kontra radikalisasi merupakan suatu proses yang terencana, terpadu, sistematis, dan berkesinambungan yang dilaksanakan terhadap orang atau kelompok orang yang rentan terpapar paham radikal terorisme yang dimaksudkan untuk menghentikan penyebaran paham radikal terorisme yang dimaksudkan untuk menghentikan penyebaran paham radikal terorisme. ${ }^{338}$ Kontra radikalisasi dilakukan oleh Pemerintah yang dikoordinasikan oleh badan yang menyelenggrakan urusan di bidang penanggulangan terorisme dengan melibatkan kementerian/lembaga terkait. ${ }^{339}$ Kontra radikalisasi dilakukan secara langsung atau tidak langsung melalui kontra narasi, kontra propoganda, atau kontra ideologi. ${ }^{340}$

Deradikalisasi merupakan suatu proses yang terencana, terpadu, sistematis, dan berkesinambungan yang dilaksanakan untuk menghilangkan atau mengurangi dan membalikkan pemahaman radikal terorisme yang terjadi. ${ }^{341}$ Deradikalisasi dilakukan kepada: a. tersangka; b. terdakwa; c. terpidana; d. narapidana; e. mantan narapidana terorisme; atau f. orang atau

337 Pasal 43B Ayat (4) Undang-Undang Nomor 5 Tahun 2018 Tentang Perubahan Atas Undang-Undang Nomor 15 Tahun 2003 tentang Penetapan Peraturan Pemerintah Pengganti Undang-Undang Nomor 1 Tahun 2002 tentang Pemberantasan Tindak Pidana Terorisme Menjadi Undang-Undang.

338 Pasal 43C Ayat (1) Undang-Undang Nomor 5 Tahun 2018 Tentang Perubahan Atas Undang-Undang Nomor 15 Tahun 2003 tentang Penetapan Peraturan Pemerintah Pengganti Undang-Undang Nomor 1 Tahun 2002 tentang Pemberantasan Tindak Pidana Terorisme Menjadi Undang-Undang

339 Pasal 43C Ayat (2) Undang-Undang Nomor 5 Tahun 2018 Tentang Perubahan Atas Undang-Undang Nomor 15 Tahun 2003 tentang Penetapan Peraturan Pemerintah Pengganti Undang-Undang Nomor 1 Tahun 2002 tentang Pemberantasan Tindak Pidana Terorisme Menjadi Undang-Undang.

340 Pasal 43C Ayat (3) Undang-Undang Nomor 5 Tahun 2018 Tentang Perubahan Atas Undang-Undang Nomor 15 Tahun 2003 tentang Penetapan Peraturan Pemerintah Pengganti Undang-Undang Nomor 1 Tahun 2002 tentang Pemberantasan Tindak Pidana Terorisme Menjadi Undang-Undang.

341 Pasal 43D Ayat (1) Undang-Undang Nomor 5 Tahun 2018 Tentang Perubahan Atas Undang-Undang Nomor 15 Tahun 2003 tentang Penetapan Peraturan Pemerintah Pengganti Undang-Undang Nomor 1 Tahun 2002 tentang Pemberantasan Tindak Pidana Terorisme Menjadi Undang-Undang. 
kelompok orang yang sudah terpapar paham radikal terorisme. $^{342}$

Deradikalisasi dilaksanakan oleh Pemerintah yang dikoordinasikan oleh badan yang menyelenggarakan urusan di bidang penanggulangan terorisme dengan melibatkan kementerian/lembaga terkait. ${ }^{343}$ Deradikalisasi terhadap tersangka, terdakwa, terpidana, dan narapidana diberikan melalui tahapan: a. identifikasi dan penilaian; b. rehabilitasi; c. reedukasi; dan d. reintegrasi sosial. ${ }^{344}$ Deradikalisasi terhadap orang atau kelompok mantan narapidana terorisme atau orang atau kelompok yang sudah terpapar paham radikal terorisme, dapat dilaksanakan melalui: a. Pembinaan wawasan kebangsaan; b. Pembinaan wawasan keagamaan; dan/atau c. Kewirausahaan. ${ }^{345}$ Pelaksanaan deradikalisasi terhadap Mantan narapidana Terorisme dan orang atau kelompok yang sudah terpapar paham radikal Terorisme dilakukan berdasarkan identifikasi dan penilaian.

Dengan diakomodirnya mekanisme penanggulangan Tindak Pidana Terorisme secara non penal di dalam Revisi UU Pemberantasan Tindak Pidana Terorisme, dalam hal ini perlu kita apresiasi komitmen pemerintah dalam mengatasi kejahatan Terorisme dengan menggunakan pendekatan non penal sebagai pendukung penanggulangan penal, keduanya merupakan pendekatan integral bagian dari perlindungan

342 Pasal 43D Ayat (2) Undang-Undang Nomor 5 Tahun 2018 Tentang Perubahan Atas Undang-Undang Nomor 15 Tahun 2003 tentang Penetapan Peraturan Pemerintah Pengganti Undang-Undang Nomor 1 Tahun 2002 tentang Pemberantasan Tindak Pidana Terorisme Menjadi Undang-Undang.

343 Pasal 43D Ayat (3) Undang-Undang Nomor 5 Tahun 2018 Tentang Perubahan Atas Undang-Undang Nomor 15 Tahun 2003 tentang Penetapan Peraturan Pemerintah Pengganti Undang-Undang Nomor 1 Tahun 2002 tentang Pemberantasan Tindak Pidana Terorisme Menjadi Undang-Undang.

344 Pasal 43D Ayat (4) Undang-Undang Nomor 5 Tahun 2018 Tentang Perubahan Atas Undang-Undang Nomor 15 Tahun 2003 tentang Penetapan Peraturan Pemerintah Pengganti Undang-Undang Nomor 1 Tahun 2002 tentang Pemberantasan Tindak Pidana Terorisme Menjadi Undang-Undang.

345 Pasal 43D Ayat (5) Undang-Undang Nomor 5 Tahun 2018 Tentang Perubahan Atas Undang-Undang Nomor 15 Tahun 2003 tentang Penetapan Peraturan Pemerintah Pengganti Undang-Undang Nomor 1 Tahun 2002 tentang Pemberantasan Tindak Pidana Terorisme Menjadi Undang-Undang. 
masyarakat (social defence). Pentingnya menerapkan penanggulangan secara non penal mengingat semakin masifnya gerakan atau kelompok teroris di Indonesia yang semakin hari, semakin meresahkan. Oleh sebab itu sarana penal dan non penal dinilai sangat efektif jika diterapkan secara bersama dalam menanggulangi Tindak Pidana Terorisme.

Namun ada sedikit catatan penting terkait istilah radikal, yang di dalam Revisi UU Pemberantasan Tindak Pidana Terorisme tidak dijelaskan secara jelas pengertian (begrip) dari istilah Radikal. Dalam Revisi UU Pemberantasan Tindak Terorisme istilah Radikal ditautkan dengan istilah terorisme. Dalam Kamus Besar Bahasa Indonesia istilah Radikal mempunyai arti: 1 secara menyeluruh; habis-habisan: 2. Amat keras menuntut perubahan (undang-undang, pemerintahan). ${ }^{346}$ Franz Magnis Suseno mengatakan bahwa aparat penegak hukum di Indonesia masih perlu memahami perbedaan pengertian teroris, fundamentalis dan radikalis. Seorang teroris, bisa jadi seorang fundamentalis dan radikalis belum tentu teroris. Ketidakpahaman akan pengertian terorisme kadang bisa menjadi sebab dilakukannya labeling oleh pemerintah terhadap orang atau kelompok tertentu. ${ }^{347}$ Pada titik ini mari kita sama-sama memahami dan medudukan radikalisme secara adil dan jernih. Bahwasanya radikalisme tidak hanya semata bersumber pada agama, namun juga amat mungkin terjadi pada kelompok ekstimis sayap kanan (right wing), sayap kiri (left wing), ekstrimis untuk isu tertentu (single issue) dan bahkan pada kelompol radical-secularism. ${ }^{348}$ Radikalisme juga secara otomatis melahirkan kekerasan dan terorisme. Ada banyak faktor dan sebab yang bersifat dinamis dan spesifik. Tidak sama pada setiap individu. Dan juga tidak linear. ${ }^{349}$ Oleh sebab itu perlu ada kesepakatan dari pembentuk undang-undang hlm. 1152

346 Dendy Sugono, Kamus Bahasa Indonesia, ( Jakarta: Pusat Bahasa, 2008),

347 Hery Firmansyah, Op.Cit, hlm. 379

348 Heru Susetyo, Mendudukan Kembali Makna Radikalisme, lihat Heru Susetyo dan Sapto Waluyo, Menangkal Terorisme, (Surabaya: Pustaka Saga, 2018), hlm. 88

349 Ibid. 
terkait pemahaman Radikal. Dengan begitu perlu direkonstruksi kembali mengenai pengertian "Radikal" sebab jika tidak seluruh aparat penegak hukum nantinya akan kebingungan dalam menentukan status pelaku, karena parameter Radikal Teroris tidak diatur secara merinci hal demikian tidak memberikan kepastian hukum.

\section{E. Penutup}

Terorisme dapat dipahami sebagai serangan terkoordinasi dan sistematis yang bertujuan membangkitkan perasaan takut, ancaman maupun ketakutan terhadap sekelompok masyarakat. Dalam hal ini Politik Hukum Penanggulangan Pemberatasan Tindak Pidana Terorisme di Indonesia dilakukan dengan menggunakan pendekatan penal dan non penal secara integral yang merupakan bagian dari perlindungan terhadap masyarakat (social defence). Langkah represif dan preventif diimplementasikan secara simultan guna memutus serangkaian aktivitas seorang atau kelompok terorisme di Indonesia.

\section{Saran}

Pemerintah harus mempertahankan eksistensi penanggulanggan Tindak Pidana Terorisme dengan pendekatan penal dan non penal guna melindungi masyarakat luas dari aktivitas terorisme yang ada. Pembentuk undang-undang sudah seyogianya merumuskan ulang makna Radikal/Radikalisme secara jelas guna memberikan parameter yang jelas bagi para aparat penegak hukum untuk menentukan status pelaku teror. 


\section{Daftar Pustaka}

\section{Buku}

Allen, Robert, Oxford School Dictionary E Thesaurus, Oxford: Oxford University Press, 2005.

Arief, Barda Nawawi, Beberapa Aspek Kebijakan Penegakan dan Pengembangan Hukum Pidana, Bandung: PT. Citra Aditya Bakti, 2005.

Arief, Barda Nawawi, Bunga Rampai Kebijakan Hukum Pidana: Perkembangan Penyusunan Konsep KUHP Baru, Jakarta: Kencana, 2017.

Arief, Barda Nawawi, Bunga Rampai Kebijakan Hukum Pidana, (Bandung: Citra Aditya Bakti, 2002.

MD, Moh. Mahfud, Politik Hukum di Indonesia, (Jakarta: Rajawali Pers, 2017).

Mertokusumo, Sudikno, Mengenal Hukum: Suatu Pengantar, (Yogyakarta: Cahaya Atma Pustaka, 2010).

Luthan, Salman, Kebijakan Kriminalisasi Di Bidang Keuangan, Yogyakarta: UII Press, 2014.

Satria, Hariman, Anatomi Hukum Pidana Khusus, Yogyakarta: UII Press, 2014.

Sudarto, Hukum dan Hukum Pidana, Bandung: Alumni, 1981.

Sudarto, Hukum Pidana dan Perkembangan Masyarakat, Bandung: Sinar Baru, 1983,

Susetyo, Heru dan Sapto Waluyo, Menangkal Terorisme, Surabaya: Pustaka Saga, 2018. 
Sugono, Dendy, Kamus Bahasa Indonesia, Jakarta: Pusat Bahasa, 2008.

Sulistyo, Hermawan, Beyond Terorism, Jakarta: Pustaka Sinar Harapan, 2002.

Sunardi, Wahid dan Imam Siddiq, Kejahatan Terorisme Perspektif Agama, Haka Asasi Manusia dan Hukum, Bandung: Refika Aditama, 2004.

Wahjono, Padmo, Indonesia Negara Berdasarkan Atas Hukum, (Jakarta: Ghalia Indonesia, 1986).

\section{Jurnal, Makalah, dll}

Radhie, Teuku Mohammada, Pembaharuan dan Politik Hukum Dalam Rangka Pembangunan Nasional, Jurnal Prisma, Nomor 6 Tahun II Desember 1973.

Garuda, Abdul Hakim, Politik Hukum Nasional, makalah disampaikan pada Karya Latihan Bantuan Hukum (Kalabahu), diselenggarakan Yayasn Lembaga Bantuan Hukum Indonesia dan Lembaga Bantuan Hukum Surabaya, (September 1985).

Wahjono, Padmo, Menyelisik Proses Terbentuknya Peraturan Perundang-undangan, dalam Majalah Forum Keadilan, Nomor 29, April 1991.

Firmansyah, Hery, Upaya Penanggulangan Tindak Pidana Terorisme di Indonesia, Jurnal Mimbar Hukum, Volume 23, Nomor 2, Juni 2011, hlm. 385.

Winarni, Luh Nila, Kebijakan Hukum Pidana Non Penal Dalam Penanggulangan Kejahatan Radikalisme Berbentuk Terorisme, Jurnal Ilmu Hukum DIH, Volume 12, Nomor 23, Februari 2016. 


\section{Peraturan Perundang-undangan}

Peraturan Pemerintah Pengganti Undang-Undang Nomor 1 Tahun 2002 tentang Pemberantasan Tindak Pidana Terorisme.

Undang-Undang Nomor 5 Tahun 2018 Tentang Perubahan Atas Undang-Undang Nomor 15 Tahun 2003 tentang Penetapan Peraturan Pemerintah Pengganti Undang-Undang Nomor 1 Tahun 2002 tentang Pemberantasan Tindak Pidana Terorisme Menjadi Undang-Undang. 